Міністерство

юстиції України

Головне територіальне

управління юстиції

Співзасновники -

Головне територіальне управління

у Херсонській області

юстиції у Херсонській області;

Одеський державний університет

Міністерство

внутрішніх справ;

Асоціація нотаріусів

Херсонської області

внутрішніх справ України

Одеський державний університет

внутрішніх справ

Зареєстрований

Міністерством

юстиції України

Асоціація нотаріусів

Херсонської області

\title{
Свідоцтво
}

Про державну реєстрацію серія КВ № 24402-14242ПР

від 28.12.2019 p.

Виходить шість разів на рік.

Мова видання: українська, російська та англійська.

На підставі Наказу Міністерства освіти та науки України № 627 від 14.05.2020 р.

\author{
Випуск 14
}

(додаток 2) журнал включено

до Переліку наукових фахових видань України категорії «Б» у галузі юридичних наук

\section{Юридичний бюлетень}

(081 «Право», 293 «Міжнародне право»).

Адреса редакції:

вул. Потьомкінська, 42/14

м. Херсон, Україна, 73000 


\section{Рекомендовано до друку Вченою радою \\ Одеського державного \\ університету внутрішніх справ \\ (протокол № 3 від 30.10.2020 р.)}

\section{Редакційна колегія:}

Головний редактор - Легеза Юлія Олександрівна, доктор юридичних наук, доцент, професор кафедри цивільного, господарського та екологічного права Інституту соціальних та гуманітарних наук Національного технічного університету «Дніпровська політехніка»

Аброськін B'ячеслав Васильович, кандидат юридичних наук, ректор Одеського державного університету внутрішніх справ

Албул Сергій Володимирович, кандидат юридичних наук, доцент, професор кафедри оперативно-розшукової діяльності Одеського державного університету внутрішніх справ

Бабенко Андрій Миколайович, доктор юридичних наук, доцент, декан факультету підготовки фахівців для органів досудового розслідування Одеського державного університету внутрішніх справ

Бондар Валерія Валеріївна, кандидат юридичних наук, доцент, завідувач кафедри адміністративного права та адміністративного процесу Херсонського факультету Одеського державного університету внутрішніх справ

Галунько Віра Миколаївна, доктор юридичних наук, професор, заступник декана Херсонського факультету Одеського державного університету внутрішніх справ

Ізбаш Катерина Сергіївна, старший науковий співробітник відділу організації наукової роботи Одеського державного університету внутрішніх справ, кандидат юридичних наук, доцент

Ісмайлов Карен Юрійович, кандидат юридичних наук, завідувач кафедри кібербезпеки та інформаційного забезпечння Одеського державного університету внутрішніх справ

Катеринчук Іван Петрович, доктор юридичних наук, доцент, професор кафедри адміністративного права та адміністративного процесу Одеського державного університету внутрішніх справ

Легеза Євген Олександрович, доктор юридичних наук, професор, професор кафедри адміністративного та митного права Університету митної справи та фінансів

Миронюк Роман Вікторович, доктор юридичних наук, професор, професор кафедри адміністративного права, процесу та адміністративної діяльності Дніпропетровського державного університету внутрішніх справ

Резніченко Семен Васильович, професор кафедри цивільно-правових дисциплін Одеського державного університету внутрішніх справ, кандидат юридичних наук, професор

Тильчик B' ячеслав B' ячеславович, кандидат юридичних наук, доцент, професор кафедри адміністративного права і процесу та митної безпеки Університету державної фіскальної служби України

Шкута Олег Олегович, доктор юридичних наук, доцент, професор кафедри професійних та спеціальних дисциплін Херсонського факультету Одеського державного університету внутрішніх справ

Vlad Vernyhora, L.L.M., BA (Hons), MA, DSocSc, Lecturer in International Relations, School of Law, Tallinn Technical University (Tallinn, Estonia)

Hans-Joachim Schramm, Prof. Dr. habil., Hochschule Wismar University of Applied Sciences Technology, Business and Design Fakultät für Wirtschaftswissenschaften Wismar Business School Philipp-Müller-Straße (Wismar, Germany)

Редколегія не завжди поділяе погляди авторів публікації

У збірнику розглядаються актуальні питання теорії держави та права, цивільного права, адміністративного права та адміністративної діяльності, проблеми протидії злочинності, юридичної психології та ін.

Для науковців, юристів-практиків, викладачів, ад'юнктів, аспірантів, слухачів, курсантів та студентів вищих навчальних закладів юридичного профілю, а також всіх тих, хто цікавиться питаннями розвитку науки та права. 


\section{MICT \\ ЗАГАЛЬНОТЕОРЕТИЧНІ ПРОБЛЕМИ ДЕРЖАВИ ТА ПРАВА}

Боброва Ю.Ю., Боброљ Ю.О.

ГЕНДЕР І МІЛІТАРИЗАЦІЯ: СУЧАСНИЙ КОНЦЕПТ. 9

Брезіна T.M.

ЗМІСТ ПРАВА НА СУДОВИЙ ЗАХИСТ,

ЙОГО ЕЛЕМЕНТИ ТА КЛАСИФІКАЦІЯ. 16

Даніліна M.I.

ФОРМУВАННЯ СОЦІАЛЬНОЇ СПРАВЕДЛИВОСТІ

ВІД ЕПОХИ АНТИЧНОСТІ ДО ЕПОХИ ВІДРОДЖЕННЯ

Зіньковський А.С., Каменщзи О.В.

СУТНІСТЬ ЮРИДИЧНИХ КАТЕГОРІЙ «ОХОРОНА», «ЗАХИСТ» ТА «ОБОРОНА»: ОСОБЛИВОСТІ

ЇХ ВИКОРИСТАННЯ У ЗАКОНОДАВСТВІ УКРАЇНИ.

Золотухіна Л.О., Легеза Ю.О.

ГАРАНТIÏ ЗАХИСТУ ПУБЛІЧНОГО ІНТЕРЕСУ.....

Кузьменко Ю.В.

АНАЛІЗ ПРАВОВОГО МЕХАНІЗМУ

ЗАБОРОНИ КАТУВАНЬ В УКРАЇНІ

Радченко О.М.

ФІНАНСОВО-ПРАВОВА ПРИРОДА ГРОШЕЙ .55

Романчук O.3.

РОЗШИРЕНЕ РОЗУМІННЯ ЕЛЕКТРОННОГО УРЯДУВАННЯ

У СУЧАСНІЙ ПРАВОВІЙ СИСТЕМІ

Сірант M.M.

ДОКТРИНАЛЬНИЙ ПІДХІД ДО ВИЗНАЧЕННЯ

ЕКОЛОГІЧНОЇ ШКОДИ У СВРОПЕЙСЬКОМУ СОЮЗ ТА В УКРАЇНІ .76

Шапран Ю.В.

ГАРАНТІЇ ВЗАЕМОДІЇ ЗАКОНОТВОРЧОСТІ

ТА ПОЛІТИЧНОГО ПЛЮРАЛІЗМУ В УКРАЇНІ:

ТЕОРЕТИКО-ПРАВОВИЙ І ПРАКТИЧНИЙ ВИМІРИ. .85

\section{ПИТАННЯ ЦИВІЛЬНОГО, ГОСПОДАРСЬКОГО ТА ТРУДОВОГО ПРАВА}

Гонгало Р.Ф.

ПРАВОВИЙ СТАТУС ІНФОРМАЦІЇ ТА ПОНЯТТЯ «ІНФОРМАЦІЯ 3 ОБМЕЖЕНИМ ДОСТУПОМ»

Каламайко А.Ю.

ЦИФРОВІЗАЦІЯ ПРАВОСУДДЯ ТА ДОСТУП

ДО ПРАВОСУДДЯ ПІД ЧАС COVID 
Моргунова T.I.

ГОСПОДАРСЬКІ САНКЦІЇ ЯК ПРАВОВИЙ ЗАСІБ

ВІДПОВІДАЛЬНОСТІ У СФЕРІ ГОСПОДАРЮВАННЯ.

Погорелова О.С.

ЗАСАДИ ЗАКОННОСТІ ЗВІЛЬНЕННЯ ПРАЦІВНИКІВ

ЗА ІНІЦІАТИВИ РОБОТОДАВЦЯ.

PUм O.M.

ПРАВОВЕ РЕГУЛЮВАННЯ ТРУДОВИХ ВІДНОСИН ХАРТІЕЮ

ОСНОВОПОЛОЖНИХ ПРАВ ЕВРОПЕЙСЬКОГО СОЮЗУ.

Rustamli Fidan Ali gizi

ANALYSIS PATENT ACTIVITY OF ORGANIZATIONS

AND MANUFACTURERS CONCERNING PHARMACEUTICAL PRODUCTS.

Сидоренко О.В.

МАТЕМАТИЧНІ ОЗНАКИ У ФОРМУЛАХ ВИНАХОДУ,

ПОВ' ЯЗАНОГО 3 КОМП'ЮТЕРНОЮ ПРОГРАМОЮ.

\section{АДМІНІСТРАТИВНЕ ПРАВО \\ ТА АДМІНІСТРАТИВНА ДІЯЛЬНІСТЬ}

Барліт А.Ю.

АДМІНІСТРАТИВНО-ПРАВОВІ ЗАСАДИ РЕАЛІЗАЦІЇ

СУБ'СКТИВНИХ ПУБЛІЧНИХ ЕКОЛОГІЧНИХ ПРАВ. 145

Лемеха P.I.

ПРАКТИКА ВЕРХОВНОГО СУДУ ТА ЕВРОПЕЙСЬКОГО СУДУ

3 ПРАВ ЛЮДИНИ У СФЕРІ ПРАВОВОГО РЕГУЛЮВАННЯ

МИТНИХ ВІДНОСИН.

Чуб А.В.

СТРУКТУРА АДМІНІСТРАТИВНО-ПРАВОВОГО

МЕХАНІЗМУ ЗАХИСТУ СУБ'СКТИВНИХ

ПУБЛІЧНИХ ПРАВ ПРИВАТНОЇ ОСОБИ.

\section{ПРОБЛЕМИ КРИМІНАЛЬНОГО ПРАВА \\ ТА КРИМІНОЛОГІї}

Барбарош Л.М.

АКТУАЛЬНІ ПИТАННЯ ЗАПОБІГАННЯ

ДОМАШНІЙ ЗЛОЧИННОСТІ: ДОСВІД ЗАРУБІЖНИХ КРАЇН.

Галунько В.М.

ПОШУК НОВИХ СТАНДАРТІВ У ВИРІШЕННІ ПРОБЛЕМ

СИСТЕМИ БЕЗПЕКИ УКРАЇНИ МАЙБУТНІМИ ПРАВООХОРОНЦЯМИ 179

Довбань I.M.

ТЕОРЕТИКО-ПРИКЛАДНІ ПЕРЕДУМОВИ ДОСЛІДЖЕННЯ

ЗАРУБІЖНОГО ДОСВІДУ ЗАПОБІГАННЯ ВЧИНЕННЮ

ДЕРЖАВНИМИ СЛУЖБОВЦЯМИ КОРУПЦІЙНИХ ЗЛОЧИНІВ 


\section{КРИМІНАЛЬНИЙ ПРОЦЕС ТА КРИМІНАЛІСТИКА;}

ОПЕРАТИВНО-РОЗШУКОВА ДІЯЛЬНІСТЬ

Гейко O.B.

ПРОБЛЕМНІ ПИТАННЯ РЕАЛІЗАЦЇ̈

ПРОЦЕСУАЛЬНИХ ПОВНОВАЖЕНЬ ДЕТЕКТИВА

НАБУ В РАЗІ ВИТРЕБУВАННЯ РЕЧЕЙ ТА ДОКУМЕНТІВ. 


\section{CONTENTS}

\section{GENERAL THEORETICAL PROBLEMS OF THE STATE AND LAW}

Bobrova Yu.Yu., Bobrov Yu.O.

GENDER AND MILITARIZATION: A MODERN CONCEPT

Brezina T.M.

THE CONTENT OF THE RIGHT TO JUDICIAL PROTECTION, ITS ELEMENTS AND CLASSIFICATION

Danilina M.I.

FORMATION OF SOCIAL JUSTICE

FROM ANTIQUITY TO THE RENAISSANCE.

Zinkovskyj A.S., Kamenshchyk O.V.

ESSENCE OF LEGAL CATEGORIES “PROTECTION”, “SECURITY" AND “DEFENSE": FEATURES OF THEIR

USE IN THE LEGISLATION OF UKRAINE.

Zolotukhina L.O., Legeza Yu.O.

GUARANTEES OF PROTECTION OF PUBLIC INTEREST

Kuzmenko Yu.V.

ANALYSIS OF THE LEGAL MECHANISM

FOR THE PROHIBITION OF TORTURE IN UKRAINE.

Radchenko O.M.

FINANCIAL AND LEGAL NATURE OF MONEY.....

Romanchuk O.Z.

EXTENDED UNDERSTANDING OF E-GOVERNMENT

IN THE CURRENT LEGAL SYSTEM.

Sirant M.M.

DOCTRINAL APPROACH TO DETERMINATION

OF ENVIRONMENTAL HARM

IN THE EUROPEAN UNION AND UKRAINE.

Shapran Yu.V.

GUARANTEES OF INTERACTION OF LEGISLATION AND POLITICAL PLURALISM IN UKRAINE:

THEORETICAL, LEGAL AND PRACTICAL DIMENSION.

\section{ISSUES OF CIVIL, COMMERCIAL AND LABOR LAW}

Gongalo R.F.

LEGAL STATUS OF INFORMATION

AND THE CONCEPT OF “RESTRICTED INFORMATION”.

Kalamaiko A.Yu.

DIGITIZATION OF JUSTICE AND ACCESS TO JUSTICE DURING COVID. 98 
Morhunova T.I.

ECONOMIC SANCTIONS AS A LEGAL MEANS OF LIABILITY

IN THE SPHERE OF MANAGEMENT.

Pohorielova O.S.

PRINCIPLES OF LEGALITY OF DISMISSAL OF EMPLOYEES

AT THE INITIATIVE OF THE EMPLOYER

Rym O.M.

REGULATION OF LABOUR RELATIONS UNDER

THE EUROPEAN UNION CHARTER OF FUNDAMENTAL RIGHTS.

Rustamli Fidan Ali gizi

ANALYSIS PATENT ACTIVITY OF ORGANIZATIONS

AND MANUFACTURERS CONCERNING PHARMACEUTICAL PRODUCTS.

Sydorenko O.V.

MATHEMATICAL SIGNS IN THE FORMULAS

OF THE INVENTION RELATED TO A COMPUTER PROGRAM

\section{ADMINISTRATIVE LAW AND ADMINISTRATIVE ACTIVITY}

Barlit A.Yu.

THE CONCEPT AND CONTENT

OF SUBJECTIVE PUBLIC ENVIRONMENTAL RIGHTS.

Lemekha R.I.

PRACTICE OF THE SUPREME COURT

AND THE EUROPEAN COURT OF HUMAN RIGHTS

IN THE AREA OF REGULATION OF THE CUSTOMS RELATIONS.

Chub A.V.

STRUCTURE OF THE ADMINISTRATIVE

AND LEGAL MECHANISM OF PROTECTION

OF THE SUBJECTIVE PUBLIC RIGHTS OF A PRIVATE PERSON. 163

\section{PROBLEMS OF CRIMINAL LAW AND CRIMINOLOGY}

Barbarosh L.M.

URGENT ISSUES OF DOMESTIC CRIMINALITY PREVENTION:

EXPERIENCE OF FOREIGN COUNTRIES.

Halunko V.N.

SEARCHING FOR NEW STANDARDS

IN SOLVING PROBLEMS OF THE SECURITY SYSTEM

OF UKRAINE BY FUTURE LAW ENFORCEMENT AGENTS

Dovban I.M.

THEORETICAL AND APPLIED PRECONDITIONS

FOR THE STUDY OF FOREIGN EXPERIENCE

IN PREVENTING CORRUPTION CRIMES COMMITTING

BY PUBLIC SERVANTS 
CRIMINAL PROCEEDINGS AND FORENSIC SCIENCE; OPERATIVE-SEARCH ACTIVITY

Geiko O.V.

PROBLEMATIC ISSUES OF THE EXERCISE

OF PROCEDURAL POWERS OF THE DETECTIVE

OF NABU DURING REQUESTING FOR OBJECTS AND DOCUMENTS

190 


\title{
ЗАГАЛЬНОТЕОРЕТИЧНІ ПРОБЛЕМИ ДЕРЖАВИ ТА ПРАВА
}

УДК 340.12:396.1:342.78

DOI https:/ / doi.org/10.32850/LB2414-4207.2020.14.01

\section{ГЕНДЕР І МІЛІТАРИЗАЦІЯ: СУЧАСНИЙ КОНЦЕПТ}

\author{
Боброва Юлія Юріївна, \\ доктор юридичних наук, \\ доцент кафедри правового забезпечення \\ (Військовий інститут Київського \\ національного університету імені Тараса \\ Шевченка, м. Київ, Україна), \\ суддя \\ (Біловодський районний суд Луганської \\ області, м. Біловодськ, Луганська \\ область, Україна) \\ Бобров Юрій Олександрович, \\ кандидат юридичних наук, \\ полковник юстиції, \\ начальник Управління правового \\ забезпечення - начальник юридичної \\ служби Збройних Сил України, суддя \\ (Івано-Франківський окружний \\ адміністративний суд, м. Івано- \\ Франківськ, Україна)
}

Сьогодні розуміння поняття гендеру зводиться до соціальної моделі жінки та чоловіка, яка визначає статус і роль у суспільстві та надає чоловікам притаманні маскулінні риси, форми поведінки, професії, а жінкам - фемінні. Питання гендерної симетрії набуло чималої популярності у різних галузях суспільних наук, стало темою безлічі наукових досліджень. Однак воно так і не знайшло свого вирішення в багатьох сферах суспільного життя нашої держави, у тому числі у військовій сфері.

У статті аналізується вплив мілітаризації, яка є наслідком збройного конфлікту на сході України, на воєнну організацію держави та врахування гендеру у Збройних Силах України. Наголошено на досі наявному стереотипному сприйнятті військовослужбовця як чоловіка, для зміни якого необхідними є соціальні трансформації, зміни у свідомості людей та, відповідно, об'єктивний погляд на проблему. Звісно, якщо ми зможемо позбутися безлічі стереотипів, упереджень, очікувань, подвійних стандартів та сумнівів, які існують у нашому суспільстві, тоді відкриється гендерно-збалансований світ рівних можливостей. Констатовано, що згідно зі статистичними даними за 2018-2020 роки сучасна українська армія є «чоловічою», жінки у ній склада- 
ють приблизно п'яту іï частину, а тому реалізацію принципу гендерної рівності слід розпочати з підвищення рівня демократичності самих гендерно-правових відносин та побудови їх на засадах саме принципів гендерного паритету. Покликається й на те, що задекларований державою комплекс заходів щодо забезпечення рівних прав та можливостей жінок і чоловіків є теоретичним механізмом реалізації принципу гендерної рівності, у тому числі і в Збройних Силах України. Однак на практиці, на наш погляд, він майже не дієвий. Зазначається, що надання рівних можливостей чоловікам і жінкам у доступі до військової служби, розбудові власної кар'єри, підвищенні свого професійного рівня має реалізовуватися через створення сприятливих умов для поєднання роботи та всіх інших сторін життя задля досягнення гендерної демократії. До вирішення проблеми слід підходити комплексно, поєднуючи досягнення науки у вирішенні гендерної проблематики, впровадження гендерного підходу в усі сфери державної політики управління у військовій та оборонній сфері через удосконалення й оцінку процесів прийняття рішень, створення законодавства, вироблення стратегічного напряму та програм.

Ключові слова: гендер, війна, чоловіки, жінки, армія, мілітаризація.

\title{
GENDER AND MILITARIZATION: A MODERN CONCEPT
}

\author{
Bobrova Yuliia Yuriivna, \\ Doctor of Law Sciences, \\ Associate Professor at the Department of \\ Legal Support \\ (Military Institute of Taras Shevchenko \\ National University of Kyiv, \\ Kyiv, Ukraine), \\ Judge \\ (Belovodsk District Court \\ of the Luhansk Region, \\ Belovodsk, Luhansk Region, Ukraine)
Bobrov Yurii Oleksandrovych, Candidate of Law Sciences, Head of the Legal Support Department - Head of the Legal Service of the Armed Forces of Ukraine, Colonel of Justice, Judge (Ivano-Frankivsk District Administrative Court, Ivano-Frankivsk, Ukraine)

The current understanding of the concept of gender is reduced to the social model of women and men, which determines the status and role in society and gives men masculine traits, behaviors, professions, and women - feminine. The issue of gender symmetry has gained considerable popularity in various fields of social sciences, has become the subject of many scientific studies, however, today it is not resolved in Ukraine, including in the military sphere. The article analyzes the impact of militarization, which is a consequence of the armed conflict in eastern Ukraine, on the process of ensuring and taking into account gender in the Armed Forces of Ukraine. Emphasis is placed on the still existing stereotypical perception of the serviceman as a man to change which requires social transformations, changes in people's consciousness and, accordingly, an objective view of the problem. Of course, if we 
can get rid of the many stereotypes, prejudices, expectations, double standards and doubts that exist in our society, then a gender-balanced world of equal opportunities will open up. It is stated that according to statistics for 2018-2020, the modern Ukrainian army is "male", women make up about one-fifth of it, and therefore the implementation of the principle of gender equality should begin with increasing the level of democracy of gender relations and building them on the basis of the principles of gender parity. It also refers to the fact that the set of measures declared by the state to ensure equal rights and opportunities for women and men is a theoretical mechanism for implementing the principle of gender equality, including in the Armed Forces of Ukraine, but in reality, in practice, in our opinion it is almost ineffective. It is stated that providing equal opportunities for men and women in access to military service, building their own careers, improving their professional level should be realized through the creation of favorable conditions for combining work and all other aspects of life to achieve gender democracy. The solution of the problem should be approached comprehensively, combining the achievements of science in solving gender issues, the introduction of a gender approach in all areas of public policy in the military and defense spheres through improving and evaluating decision-making processes, legislation, strategic direction and programs.

Key words: gender, war, men, women, army, militarization.

Війна хоч і жіночого роду, але має чоловіче обличчя. Вона ні для кого не проходить безслідно. Її катастрофічно негативний вплив, згубні наслідки та руйнівний відголос залишають слід у життях, долях, спогадах і світосприйнятті всіх без винятку ії учасників. Проте збройний конфлікт не однаковою мірою позначається на чоловіках і жінках. Досі під тиском стереотипів залишається сприйняття чоловіка як воїна, який має померти за власну сім'ю, державу, а жінки - як медичної сестри, біженки, матері-одиначки, вдови, основне призначення якої - народжувати дітей. Воно й не дивно, адже Збройні Сили України станом на сьогодні все ще мають маскулінне забарвлення, хоча держава на законодавчому рівні вже реалізувала право жінки на військову службу, нормативно забезпечивши таким чином принцип гендерної рівності в армії.

Мілітаризація у своєму узагальненому смисловому розумінні є процесом легітимізації, так званого «узаконення» війни.

Війна як поле діяльності по-різному залучає жінок і чоловіків до воєнних конфліктів, і вони виконують в ній різні ролі. Так, жіночими є такі ролі:

- жінки і дівчата як вояки;

- жінки як матері і дружини вояків;

- жінки як члени громадянської спільноти, залучені до військових конфліктів;

- жінки як жертви згвалтування та інших військових злочинів;

- жінки як учасники військових злочинів;

- жінки як годувальниці сім'ї і керівники домогосподарств, робітники в тилу;

- жінки, які доглядають дітей, турбуються про людей похилого віку, поранених та інвалідів;

- жінки як організатори соціального і політичного життя.

Для чоловіків війна відводить такі ролі:

- чоловіки і хлопці як вояки;

- чоловіки як жертви насильства і зловживань;

- чоловіки як батьки та годувальники, відокремлені від своїх сімей;

- чоловіки як свідомі противники війни або дезертири;

- чоловіки як організатори соціального і політичного життя;

- чоловіки як (психологічно і/ або фізично) поранені чи інваліди [3, с. 38]. 
Так, за даними Головного управління персоналу (J1) Генерального штабу Збройних Сил України станом на 1 січня 2018 року у 3бройних Силах України несло військову службу 56454 жінок, що становить 22\% від загальної чисельності, з яких 24897 військовослужбовців це - $12 \%$ від загальної чисельності (офіцерів, у тому числі у військовому званні - 3068 жінок (6,1\%); 87 полковників (2,1\%); 278 підполковників (3,1\%); 478 майорів (3,8\%); 583 капітанів (6,2\%); 917 старших лейтенантів (13,6\%); 569 лейтенантів (8\%) та 156 молодших лейтенантів - (10\%); 5316 сержантів (11,2\%), 15703 солдатів (15,9\%) та 810 курсантів (7,6\%). Серед працівників ЗС України 31557 жінок - 67,3\% від загальної кількості.

Станом на 1 січня 2019 року у Збройних Силах України несло військову службу 55805 жінок, що становить 21,1\% від загальної чисельності, з яких 26617 військовослужбовців це - $13 \%$ від загальної чисельності (офіцерів, у тому числі у військовому званні 3574 жінок (7,1\%); 95 полковників (2,3\%); 306 підполковників (3,4\%); 487 майорів (3,9\%); 614 капітанів (6,5\%); 781 старших лейтенантів (11,5\%); 985 лейтенантів (14\%) та 306 молодших лейтенантів - (21,7\%); 6125 сержантів (13,3\%), 16004 солдатів (16,4\%) та 914 курсантів (8,1\%). А також 29188 жінок - працівників 3С України, що складає 62,4\%.

У січні 2020 року у Збройних Силах України налічувалося 57132 жінок, що становить 21,1\% від загальної чисельності, з яких 29760 військовослужбовців це - 14\% від загальної чисельності (офіцерів, у тому числі у військовому званні - 4250 жінок (8,1\%); 113 полковників (2,8\%); 319 підполковників (3,6\%); 474 майорів (3,8\%); 708 капітанів (7,6\%); 920 старших лейтенантів (13,6\%); 1041 лейтенантів (11,5\%) та 675 молодших лейтенантів - (48\%); 6973 сержантів (14,5\%), 17438 солдатів (17,3\%) та 1099 курсантів (9,7\%). А також 27372 жінок - працівників ЗС України, що складає 58,9\% [2].

Наведені вище показники свідчать, що жінок в українській армії з кожним роком стає все більше і більше, однак у порівнянні із чоловіками їхній відсоток все ще малий - 22\%, що підтверджує наявність ряду до кінця не вирішених «гендерних питань» у цій сфері.

Попри наявність певного кола визначень та ознак того, що сьогодні зветься «гендерна рівність», «дискримінація», універсальної формули-дефініції цих понять не існує, оскільки їх сприйняття змінюється залежно від геополітичних чинників, культурних традицій, моральних і правових цінностей суспільства й законодавства держав.

Згідно з Конвенцією ООН з ліквідації всіх форм дискримінації щодо жінок 1979 року дискримінація - це розрізнення, переваги, недопущення, що мають місце за будьякою ознакою, призводять до порушення рівності прав чи можливостей або до їх обмеження [3]. Таким чином, гендерна рівність і дискримінація за ознакою статі - це поняття, пов'язані між собою: відсутність дискримінації означає рівність, а рівність виключає дискримінацію.

Як вихідні дані вважатимемо, що гендерна рівність $є$ процесом справедливого відношення до жінок і чоловіків та означає, що жінки та чоловіки мають однаковий суспільний статус, аналогічні умови для реалізації свого потенціалу згідно зі здібностями, рівні права, обов' язки чи гарантії, тотожні можливості у прийнятті суспільно важливих рішень, участі у соціальному розвитку та отриманні результатів указаного.

Як стверджує К.Б. Левченко, додаткової ваги гендерна рівність набуває як умова модернізації суспільства та успішності розпочатих реформ [4, с. 8].

Натепер, під час збройного конфлікту в Україні, достатньо велика частина жінок не $\epsilon$ пасивними спостерігачками. Вони виконують активні функції - служать у військових формуваннях, правоохоронних органах тощо. Жінки складають більшість волонтерських груп та організацій, надаючи допомогу як військовим, так і громадянам, що залишилися на тимчасово окупованій території, а також внутрішньо переміщеним 
особам [5, с. 11]. Війна ж підсилює вже існуючі глибокі статеві поділи, наголошуючи на чоловіках як тих, хто чинить насильство, а жінках - як жертвах [6, с. 23].

Також варто звернути увагу і на той факт, що у районі проведення Операції об'єднаних сил станом на 1 січня 2018 року перебували 1763 жінки-військовослужбовця (5,2\% від загальної кількості), серед яких 131 офіцер (2,5\%) та 1632 сержантів та солдат (5,6\%). У січні 2019 року їх кількість зросла до 2576 осіб (7,4\%): 181 офіцер (2,9\%) і $2395(8,4 \%)$ сержантів та солдат. На початок 2020 року 3045 жінок-військовослужбовців перебували в районі проведення ООС (9\%), з них: 255 офіцерів (4,2\%) та 2790 (10\%) сержантів та солдат. У липні 2020 року кількість жінок, які несуть військову службу в ООС, збільшилася до 3156 осіб (9,3\%), серед яких 273 (4,5\%) офіцерів та 2883 (10,4\%) сержантів та солдат [2].

Отже, сучасні жінки, які крізь призму давно сформованих стереотипних уявлень про фемінність почали набувати й маскулінних рис, збільшуючи своє представництво в Збройних Силах України, несучи військову службу на рівні із чоловіками, більше того - беручи активну участь у комплексі військових і спеціальних організаційно-правових заходів українських силових структур, спрямований на протидію діяльності незаконних російських та проросійських збройних формувань у війні на сході України.

Із Резолюції Ради Безпеки ООН 1325 «Жінки, мир, безпека» слідує, що аби збільшити вплив жінок на прийняття рішень у справі запобігання конфліктам і їх вирішення Резолюція наполегливо закликає держав-учасниць забезпечити зростання представництва жінок на всіх рівнях прийняття рішень у національних, регіональних, міжнародних інституціях і в механізмах запобігання конфліктам і їх вирішення. Резолюція також заохочує генерального секретаря реалізувати його план стратегічних дій зі сприяння збільшенню представництва жінок на керівних посадах у структурах із вирішення конфлікту та мирних процесів [7].

Може видатися, ніби залучення жінок до збройних сил свідчить, що імплементація програми «Жінки, мир і безпека» дає державам змогу зробити війну кращою. Але насправді включення жінок до інституції, чия основна мета - здійснення насильства щодо «інших», аби захистити «своїх» - не радикальна дія. Думка, що стратегія «додати жінок і перемішати» може змінити мілітаризовану маскулінність, хибна. Як пише Ганна Райт, «заклики наймати більше жінок справді фемінізують мілітаризм, чи все-таки мілітаризують фемінізм?». Це риторичне питання увиразнює той факт, що владні структури, які феміністки хочуть зруйнувати, є тими самими структурами, що забезпечують доступ жінок до прийняття рішень. Таким чином, у рамках Резолюції 1325 жінок залучають до сектору безпеки та збройних сил у спосіб, який не підважує глибоко маскулінізованої культури мілітаризму, а відтак владні структури нерівностей і система війни досі не проблематизовані [8]. Справді, мілітаризація крізь «гендерні окуляри», має більшій мірі стереотипне сприйняття жінок як таких, яких потрібно захищати замість залучення їх до збройних сил.

Задля забезпечення гендерної рівності під час несення військової служби у Збройних Силах України Верховна Рада України 6 вересня 2018 року частину дванадцяту статті 1 Закону України «Про військовий обов'язок і військову служб» доповнила положенням про те, що жінки виконують військовий обов'язок на рівних засадах із чоловіками (за винятком випадків, передбачених законодавством 3 питань охорони материнства та дитинства, а також заборони дискримінації за ознакою статі), що включає прийняття в добровільному порядку (за контрактом) та призов на військову службу, проходження військової служби, проходження служби у військовому резерві, виконання військового обов'язку в запасі та дотримання правил військового обліку. 
Крім того, внесла зміни до статті 269 Статуту внутрішньої служби Збройних Сил України та визначила, що військовослужбовці до складу добового наряду призначаються 3 додержанням законодавства 3 питань охорони материнства та дитинства [9].

Більше того, ст. 176 Кодексу законів про працю України [10] передбачає заборону залучення вагітних жінок і жінок, що мають дітей віком до трьох років, до нічних, надурочних робіт, робіт у вихідні дні і направлення їх у відрядження, а положення ст. 177 КЗпП України визначає, що жінки, що мають дітей віком від трьох до чотирнадцяти років або дітей з інвалідністю, не можуть залучатись до надурочних робіт або направлятись у відрядження без їх згоди.

Оскільки добовий наряд призначається для підтримання внутрішнього порядку, охорони особового складу, озброєння, боєприпасів, бойової та іншої техніки, приміщень і майна військової частини (підрозділу), контролю за станом справ у підрозділах і своєчасного вжиття заходів для запобігання правопорушенням, а також для виконання інших обов'язків внутрішньої служби [11] - він є нічим іншим, як видом надурочних робіт. Таким чином, реалізуючи право жінки на материнство, законодавець створив ряд труднощів для командування військової частини. Так, з одного боку, в силу забезпечення та реалізації гендерної рівності військову службу жінки несуть нарівні із чоловіками, а з іншого - призначити до добового наряду жінок-військовослужбовців практично неможливо. Навіть більше, ця норма є дискримінаційною щодо чоловіків-військовослужбовців, які теж мають дітей, але вищевказані пільги до них не застосовуються.

Рисами, які наділяються збройні сили, є влада, насилля, підпорядкованість, контроль, ієрархія, субординація, але слід зважати й на те, що особистісні характеристики, потреби, психологічні портрети чоловіків і жінок $є$ різними. Тому й інтерпретація наведеного для різних статей не буде однаковою. Таким чином, урахування гендеру є вкрай необхідним під час організації управління армією.

Доречно щодо цього зауважує Л.О. Воронько, що передова європейська практика адміністрування гендерної рівності йде шляхом формування і практичного втілення ідеї гендерного цілепокладання в чинному законодавстві, сутність якої зводиться до планування цілі досягнення гендерної рівності за наступних умов: гендерна рівність визнається ревалентною в кожному державному органі; ідея гендерної рівності набуває значення відправної основи під час організації побудови органів державної влади; забезпечення внутрішнього контролю, щоб питання гендерної рівності не втрачалося в риториці чи рутинних справах органів державної влади [12].

Таким чином, задекларована гендерна рівність українського суспільства існує тільки формально на папері, а держава не в змозі на нинішньому етапі іiі розвитку створити цивілізовану сучасну політико-правову систему реалізації принципу рівності чоловіків і жінок. I хоча державна гендерна політика і зазнала змін на краще, але сьогодні юридична гендерна рівність не може подолати фактичну нерівність між чоловіками і жінками у різних аспектах життя, у тому числі в ЗСУ України, а тому має формальний характер.

\section{Список використаних джерел:}

1. Мельник Т., Кобелянська Л. Гендер у термінах, правових актах і практиці перетворень: словник-довідник. Київ, 2020. 239 с.

2. За статистичними даними Головного управління персоналу (J1) Генерального штабу Збройних Сил України.

3. Конвенція ООН з ліквідації всіх форм дискримінації щодо жінок 1979 року. URL: http://zakon.rada.gov.ua/laws/show/995_207 (дата звернення: 01.09.2020).

4. Левченко К.Б. Гендерне тяжіння. Київ, 2019. 189 с. 
5. Ковальчук Л.Г., Козуб Л.І., Левченко К.Б., Легенька М.М., Суслова О.І. Жінки. Мир. Безпека: Інформаційно-навчальний посібник 3 гендерних аспектів конфліктів для фахівців сектору безпеки. Київ, 2017. 264 с.

6. Cockburn Cynthia Gender Relations as Causal in Militarization and War: A Feminist Standpoint in Making gender, making war: violence, military and peacekeeping practices, eds. A. Kronsell \& E. Svedberg, New York 2012. P. 23.

7. РезолюціяРадиБезпекиООН1325 «Жінки,мир,безпека»прийнятаРадоюБезпеки 31 жовтня 2000 року. URL: https://zakon.rada.gov.ua/laws/show/995_669\#Texthttps:/ / zakon.rada.gov.ua/laws/show/995_669\#Text (дата звернення: 05.09.2020).

8. Нікогосян А. Привласнення фемінізму: гендер, мілітаризм і Резолюція ООН 1325. Критика фреміністична. 2019, № 2.

9. Закон України «Про внесення змін до деяких законів України щодо забезпечення рівних прав і можливостей жінок і чоловіків під час проходження військової служби у Збройних Силах України та інших військових формуваннях» від 6 вересня 2018 року № 2523-VIII. URL: https:/ / zakon.rada.gov.ua/laws/show/2523-19\#Техt (дата звернення: 05.09.2020).

10. Кодекс законів про працю України від 10 грудня 1971 року № 322-VIII. URL: https:/ / zakon.rada.gov.ua/laws/show/322-08\#Text (дата звернення: 05.09.2020).

11. Закон України «Про Статут внутрішньої служби Збройних Сил України» від 24березня1999року №548-XIY.URL:https:/ / zakon.rada.gov.ua/laws/show/548-14\#Text (дата звернення: 05.09.2020).

12. Воронько Л.О. Принципи гендерної політики в системі державного управління: поняття, сутність, характеристика: підручник. Запоріжжя, 2011. 132 с. URL: http:/ / academy.gov.ua/ej/ ej15/txts/12VLOPSH.pdf (дата звернення: 05.09.2020). 
УДК 342.72(477):341.645

DOI https:// doi.org/10.32850/LB2414-4207.2020.14.02

\title{
ЗМІСТ ПРАВА НА СУДОВИЙ ЗАХИСТ, ЙОГО ЕЛЕМЕНТИ ТА КЛАСИФІКАЦІЯ
}

\author{
Брезіна Тетяна Миколаївна, \\ суддя \\ (Чернівецький окружний \\ адміністративний суд, м. Чернівці, \\ Україна), \\ аспірант кафедри конституційного \\ права та порівняльного правознавства \\ (Ужгородський національний \\ університет, м. Ужгород, Україна)
}

Стаття присвячена правомірності та гарантованості кожному «права на звернення до суду» за судовим захистом та права отримання такого. При цьому значна увага фокусується на первинності «можливості» зацікавленої особи звернутися в суд для порушення провадження судової діяльності 3 метою захисту порушеного права або охоронюваного законом інтересу із подальшою деталізацією того факту, що всі наступні можливості, пов' язані з розглядом спору та безпосереднім здійсненням судового захисту, не можуть охоплюватися змістом права на звернення за судовим захистом. Зазначені правомочності складають зміст іншого складника права на судовий захист, права на отримання судового захисту. В досліджуваній проблемі зміст права на судовий захист характеризується як нерозривна єдність двох правомочностей - права вимоги здійснення щодо себе певних дій і права вчиняти свої активні дії. Констатується можливість вимагати виконання або дотримання обов' язку, дотримання судом встановлених законом процесуальних норм з метою захисту прав, свобод і законних інтересів та права на активні дії, що полягає в можливості особи самій звертатись за захистом свого права, тобто вчиняти юридично значущі активні дії. А можливості вимоги здійснення захисту прав та інтересів кореспондується обов' язок судових органів здійснити захист прав та інтересів суб'єкта, в установленому законом процесуальному порядку. Правосуддя за своїм змістом визнається таким за умови його відповідності вимогам справедливості та гарантованості і забезпеченості ефективного поновлення в правах. Такі положення є загальновизнаними і прийнятими всією міжнародною спільнотою, закріплені Загальною декларацією прав людини, Міжнародним пактом про громадянські та політичні права, а також Конвенцією про захист прав людини та основних свобод.

Ключові слова: судовий захист, звернення до суду, судова діяльність, конституційні межі захисту, права людини. 


\title{
THE CONTENT OF THE RIGHT TO JUDICIAL PROTECTION, ITS ELEMENTS AND CLASSIFICATION
}

\author{
Brezina Tetiana Mykolaivna, \\ Judge \\ (Chernivtsi District Administrative Court, \\ Chernivtsi, Ukraine), \\ Graduate Student at the Department of \\ Constitutional Law and Comparative Law \\ (Uzhhorod National University, \\ Uzhhorod, Ukraine)
}

The article is devoted to the legality and guarantee of everyone's "right to go to court" for judicial protection and the right to receive such. At the same time, considerable attention is focused on the primary "pportunity" of the person concerned to go to court to initiate legal proceedings in order to protect the violated right or legally protected interest, further detailing the fact that all subsequent opportunities related to litigation and direct judicial proceedings. protection, may not be covered by the content of the right to seek judicial protection. These powers constitute the content of another component of the right to judicial protection, the right to receive judicial protection. In the problem under study, the content of the right to judicial protection is characterized as an inseparable unity of two powers - the right to demand certain actions in relation to themselves and the right to take active action. It is stated that it is possible to demand fulfillment or observance of duty, observance by the court of procedural norms established by law in order to protect rights, freedoms and legitimate interests and the right to active action, which is the ability of a person to seek protection of his right. And the possibility of requiring the protection of rights and interests corresponds to the obligation of judicial authorities to protect the rights and interests of the subject, in the manner prescribed by law. Justice, in its content, is recognized as such provided that it meets the requirements of justice and guarantee and ensure the effective restoration of rights. Such provisions are universally recognized and accepted by the entire international community, enshrined in the Universal Declaration of Human Rights, the International Covenant on Civil and Political Rights, and the Convention for the Protection of Human Rights and Fundamental Freedoms.

Key words: judicial protection, appeal to court, judicial activity, constitutional limits of protection, human rights.

Метою статті є з'ясування змісту права на судовий захист, його елементів, що нерозривно пов'язані між собою, а також про його трансформацію із «права на судовий захист», що найперше існує як право конституційне та відображається в рамках конституційних правовідносин в «суб'єктивне публічне» (процесуальне право).

Проблематикою дослідження права на судовий захист та визначення права на судовий захист були предметом наукових розвідок таких вчених науковців, як О.І. Антонюк, В.Ф Бойко, В.В. Городовенко, П.М. Рабинович, О.В. Лемако, Ю.М. Тодика тощо. В юридичній науці право на судовий захист необхідно розглядати перш за все як інститут конституційного права, в реаліях його, проте, часто уподібнюють до процесуального права на правосуддя.

«Кожен має право на захист своїх інтересів та суб'єктивних прав та правосудне рішення», - влучно зауважив О.О. Добровольський у своїй роботі «Позовна форма захисту права» $[1$, с. 119]

На думку С.Н. Братуся, забезпеченість суб'єктивного права можливістю державного примусу є його невід'ємною якістю і така можливість існує не паралельно з іншими, 
закріпленими в суб'єктивному праві можливостями, а властива їм самим, тому що без цього вони не були б юридичними можливостями [2, с. 73].

Відповідно до ст. 55 Конституції України права і свободи людини і громадянина захищаються судом. Кожному гарантується право на оскарження в суді рішень, дій чи бездіяльності органів державної влади, органів місцевого самоврядування, посадових і службових осіб [3].

Стаття 8 Конституції України передбачає, що норми Конституції України є нормами прямої дії. Звернення до суду для захисту конституційних прав і свобод людини і громадянина безпосередньо на підставі Конституції України гарантується [3].

Найвищу юридичну силу Конституції України та пряму ії дію на всій території в сучасному розумінні права на судовий захист слід розуміти як універсальне право кожної особи на здійснення захисту своїх порушених прав і свобод в органах судової влади. Таке розуміння відповідає загальновизнаним нормам і принципам міжнародного права. Стаття 8 Загальної декларації прав людини визнає право кожного на ефективне відновлення в правах компетентними національними судами [4]. Конвенція про захист прав людини і основоположних свобод, зокрема стаття 6, передбачає право на доступ до судового захисту та справедливий розгляд у розумний строк [4]. Стаття 2 Міжнародного пакту про громадянські і політичні права вказує на обов'язок держав розвивати можливості судового захисту [5].

Зміст конституційного права на захист дозволяє виділити такі основні складники розуміння цього права:

- по-перше, судовий захист - це захист прав і інтересів, що здійснюється судами загальної юрисдикції;

- по-друге, судовий захист гарантується кожному;

- по-третє, Конституція гарантує судовий захист усіх прав, свобод та охоронюваних законом інтересів.

Право на звернення згідно з правилами підвідомчості до компетентного суду за вирішенням матеріально-правового спору, господарського спору, можливість оскарження рішень, дій чи бездіяльності органів державної влади, органів місцевого самоврядування, посадових і службових осіб, включаючи можливість визнання протиправним або не чинним нормативно-правового акта чи окремих його положень, визнання протиправним та скасування індивідуального акта чи окремих його положень. Право на судовий захист складається з двох складників: право на звернення до суду за судовим захистом і право на отримання судового захисту, які мають виключно публічно-правову природу, тобто спрямовані до держави в особі суду, який є головним суб'єктом механізму реалізації права на судовий захист [6, с. 27].

Право на звернення до суду за судовим захистом - це встановлена законом можливість заінтересованої особи звернутися до суду для порушення провадження судової діяльності з метою захисту порушеного права або охоронюваного законом інтересу. Інститут права на звернення до суду включає у свій зміст саме пред'явлення до суду позову (заяви) і прийняття його до провадження судом. Всі наступні можливості, пов'язані з розглядом спору і безпосереднім здійсненням судового захисту, не можуть охоплюватися змістом права на звернення за судовим захистом. Зазначені правомочності складають зміст іншого складника права на судовий захист - права на отримання судового захисту. Право на отримання судового захисту - це можливість використовувати встановлений законом процесуальний механізм для захисту своїх прав та інтересів в органах судової влади, можливість здійснити захист свого права або інтересу в суді, забезпечена процесуальної обов'язком суду надати зазначений захист, тобто використовувати всі надані суду процесуальним законом можливості 
для правильного та своєчасного розгляду справи і винесення законного та обгрунтованого судового рішення. Отримати судовий захист - означає використовувати встановлені процесуальні можливості, реалізація яких у кожному конкретному разі забезпечується діяльністю відповідних судових органів [6, с. 28].

Зміст суб'єктивного права на судовий захист становить сукупність визначених законом повноважень, якими володіє суб'єкт цього права, серед яких можна виділити право на пред'явлення позову, право на його забезпечення, право клопотати про призначення експертизи, право ставити запитання свідкам, експертам, перекладачам тощо. Вказаний підхід, як зазначає Я. Ніколаєнко, дозволяє вивести таку структуру змісту розглянутого права: правоповедінка - можливість певної (причому гарантованої) поведінки уповноваженої сторони. Вона проявляється, наприклад, у праві громадянина звернутися до суду за захистом своїх порушених або оспорюваних прав і свобод; правовимога - можливість вимагати відповідної поведінки від інших осіб [7, с. 48]. Це право полягає, зокрема, у праві на справедливий розгляд справи на підставі норм матеріального і процесуального права; право-примус можливість у разі потреби вдатися до заходів державного примусу. Наприклад, це може бути право на отримання кінцевого результату у вигляді законного та обгрунтованого судового рішення; правокористування - співвідноситься з матеріальним аспектом обсягу поведінки уповноваженого суб'єкта право на реальне виконання рішення суду. Зазначені компоненти у поєднанні становлять зміст суб'єктивного права як загального поняття. Саме воно, абстрагуючись від незліченних видів суб'єктивних прав, відображає загальні властивості права громадян на судовий захист. Разом з тим наведений перелік не носить вичерпний характер, у динаміці розвитку права громадян на судовий захист він розширюється. Можна зробити висновок, що визначення змісту права на судовий захист - це рівною мірою питання як матеріального, так і процесуального права .

Існують різні погляди на сутність права на судовий захист, а саме: право на судовий захист полягає в тому, що за певних умов особа може вимагати від конкретного суду винесення рішення про застосування одного із способів захисту права, а суд зобов'язаний винести рішення відповідного змісту; під конституційним правом на судовий захист розуміється право на правосуддя, право на отримання судового захисту, а цивільне судочинство - це сфера, в якій реалізується конституційне право на судовий захист; право на судовий захист складається з двох аспектів: права на відновлення порушених прав, права на відшкодування збитку, тобто права на задоволення матеріальної вимоги (матеріальний аспект права на судовий захист); та права на звернення до судових органів, тобто права на судовий розгляд заявленої вимоги, права на відкриття провадження у справі, на судове рішення (процесуальний аспект права на судовий захист).

У своїй роботі «Суд в механізмі реалізації права на судовий захист в цивільному і арбітражному процесі» О.В. Абознова спробувала дати визначення поняттю права на судовий захист наступним чином: «право на судовий захист можна визначити як суб'єктивну можливість будь-якої особи в цілях захисту порушених або оспорюваних прав, свобод і охоронюваних законом інтересів (як дійсних, так і гарантованих) скористатися встановленим законом процесуальним порядком для захисту своїх прав та інтересів в органах судової влади» [6, с. 28].

Право на судовий захист є самостійним суб'єктивним правом. Як і будь-яке суб'єктивне право, право на судовий захист до початку своєї реалізації структурно складається 3 двох правомочностей: права вимоги здійснення щодо себе певних дій і права на свої активні дії. Обидві ці правомочності стосовно до права на судовий захист нерозривно пов' язані один з одним. 
Можливості вимоги здійснення захисту прав та інтересів в органах судової влади відповідно кореспондується обов'язок судових органів здійснити захист прав та інтересів суб'єкта в установленому законом процесуальному порядку.

Цілком правильно зазначає О.В. Абознова про те, що право на судовий захист спочатку існує як право конституційне і складається в рамках конституційних правовідносин, а вже з початком своєї реалізації трансформується у суб'єктивне публічне (процесуальне право) [6, с. 29]. Загальними юридичними фактами, що породжує за собою виникнення галузевого суб'єктивного права на судовий захист, є звернення суб'єкта у відповідний орган судової влади, прийняття позовної заяви і порушення провадження по справі. Враховуючи наведене, право на судовий захист не можна розглядати тільки в рамках конституційних правовідносини, а в їх нерозривному зв' язку з іншими правовідносинами, що виникають в державі.

Публічний характер суб'єктивного права на судовий захист визначається з огляду на те, що всяке суб'єктивне публічне право - це правомочність суб'єкта права по відношенню до державної влади. Держава, наділяючи своїх суб'єктів відповідними правами, одночасно гарантує їх захист, в тому числі судовий, надавши кожному право на судовий захист, і забезпечивши можливість його дійсної реалізації у встановленому законом процесуальному порядку. Право на судовий захист є універсальною правовою категорією, яка застосовується до всіх і всіма суб'єктам правовідносин за такою схемою. У разі порушення дійсне або передбачуване право належить особі суб'єктивного приватного права, вона може вибрати судовий спосіб захисту цього права, тобто використати належне йому суб'єктивне публічне право на судовий захист. Застосування права на судовий захист для захисту конкретного порушеного або оспорюваного права (або передбачуваного таким) проводиться за допомогою звернення до відповідного суду з позовною заявою і подальшого використання механізму судового захисту у межах встановленого законом процесуального порядку. Публічні права захищаються шляхом використання права на судовий захист таким же чином. В цьому виявляється універсальність права на судовий захист, яке належить всім і приводиться в дію за допомогою механізму реалізації цього права [8 с. 45].

Захист прав і свобод людини за допомогою органів судової влади провадиться шляхом здійснення правосуддя. У юридичній літературі під ним розуміється державна діяльність, яку провадить суд шляхом розгляду й вирішення в судових засіданнях в особливій, установленій законом процесуальній формі цивільних, кримінальних, господарських та адміністративних справ .

Складовими елементами змісту права на судовий захист, враховуючи міжнародні стандарти, є: 1) право на судовий розгляд справи; 2) справедливість судового розгляду; 3) публічність розгляду справи та проголошення рішення; 4) розумний строк розгляду справи: 5) розгляд справи судом, встановленим законом; 6) незалежність і безсторонність суду.

Право на розгляд справи означає право особи звернутися до суду та право на те, що iї справа буде розглянута і вирішена судом. Особі має бути забезпечена можливість реалізувати вказане право без будь-яких перепон чи ускладнень. Здатність особи безперешкодно отримати судовий захист є змістом поняття доступу до правосуддя. Перешкоди у доступі до правосуддя можуть виникати як через особливості внутрішнього процесуального законодавства, так і через передбачені матеріальним правом обмеження. Для Свропейського суду з прав людини природа перешкод у реалізації права на доступ до суду не має принципового значення. 3 тексту ст. 6 Конвенції слідує, що доступність правосуддя є невіддільним елементом права на справедливий суд, хоча сам термін «доступність» у наведеній статті не вживається [9]. 
В аспекті вказаних елементів змісту права на судовий захист слід зупинитися на окремих рішеннях ССПЛ.

У справі «Чуйкіна проти України» «...Суд нагадує, що процесуальні гарантії, викладені у статті 6 Конвенції, забезпечують кожному право звертатися до суду 3 позовом щодо своїх цивільних прав та обов'язків. Таким чином, стаття 6 Конвенції втілює «право на суд», у якому право на доступ до суду, тобто право ініціювати в судах провадження з цивільних питань, становить один з його аспектів (див. рішення від 21 лютого 1975 року у справі «Голдер проти Сполученого Королівства» (Golder v. the United Kingdom), пп. 28-36, Series А № 18). Крім того, порушення судового провадження саме по собі не задовольняє усіх вимог пункту 1 статті 6 Конвенції. Ціль Конвенції - гарантувати права, які є практичними та ефективними, а не теоретичними або ілюзорними. Право на доступ до суду включає в себе не лише право ініціювати провадження, а й право отримати «вирішення» спору судом. Воно було б ілюзорним, якби національна правова система Договірної держави дозволяла особі подати до суду цивільний позов без гарантії того, що справу буде вирішено остаточним рішенням в судовому провадженні. Для пункту 1 статті 6 Конвенції було б неможливо детально описувати процесуальні гарантії, які надаються сторонам у судовому процесі - провадженні, яке є справедливим, публічним та швидким - не гарантувавши сторонам того, що їхні цивільні спори будуть остаточно вирішені (див. рішення у справах «Мултіплекс проти Хорватії» (Multiplex v. Croatia), заява № 58112/00, п. 45, від 10 липня 2003 року, та «Кутіч проти Хорватії (Kutic v. Croatia), заява № 48778/99, п. 25, ECHR 2002- II). 51. У цій справі національні органи покладалися на той факт, що орган державної влади було ліквідовано без правонаступництва, що стало підставою для закриття провадження щодо цього органу. Суд встановив, що ліквідація державної установи без правонаступництва не може звільнити державу від необхідності виконання рішення щодо ліквідованого органу. Суд також зазначив, що «інший висновок дозволить державі використовувати такий підхід, щоб уникати сплати боргів своїх органів, особливо беручи до уваги те, що потреби, які змінюються, змушують державу часто змінювати свою організаційну структуру, включаючи формування нових органів та ліквідацію старих» (рішення від 15 липня 2010 року у справі «Нікітіна проти Росіï» (Nikitina v. Russia), заява № 47486/07, п. 19, наразі ще не набуло статусу остаточного) [10. с, .31.]. Подібний підхід слід застосовувати до судового провадження у справі проти державного органу, в якому особа оскаржує виконавче провадження, враховуючи, що це виконання було і залишається обов' язком держави, незалежно від того, який конкретно орган відповідає за виконання цієї функції у будь-який момент часу. Тому ліквідація відділу Державної виконавчої служби без правонаступництва у цій справі призвела до відмови заявниці у праві на вирішення суті її позову остаточним рішенням суду щодо відшкодування. Отже, Суд доходить висновку, що такою відмовою заявниця була позбавлена права на доступ до суду. Таким чином, у цій справі було порушення пункту 1 статті 6 Конвенції» [10, с. 43].

Таким чином, право на звернення до суду за судовим захистом - це встановлена законом можливість заінтересованої особи звернутися в суд для порушення провадження судової діяльності з метою захисту порушеного права або охоронюваного законом інтересу. Інститут права на звернення до суду включає у свій зміст саме пред'явлення до суду позову (заяви) і прийняття його до провадження судом. Всі наступні можливості, пов'язані з розглядом спору і безпосереднім здійсненням судового захисту, не можуть охоплюватися змістом права на звернення за судовим захистом. Зазначені правомочності складають зміст іншого складника права на судовий захист - права на отримання судового захисту. Право на отримання судового захисту - це можливість 
використовувати встановлений законом процесуальний механізм для захисту своїх прав та інтересів в органах судової влади, можливість здійснити захист свого права або інтересу в суді, забезпечена процесуальним обов'язком суду надати зазначений захист, тобто використовувати всі надані суду процесуальним законом можливості для правильного та своєчасного розгляду справи і винесення законного та обгрунтованого судового рішення. Отримати судовий захист - означає використовувати встановлені процесуальні можливості, реалізація яких у кожному конкретному разі забезпечується діяльністю відповідних судових органів.

\section{Список використаних джерел:}

1. Добровольский А. А. Исковая форма защиты права / А.А. Добровольский. Москва, МГУ. 1965. 346 с.

2. Братусь С.Н. Юридическая ответственность и законность / С.Н. Братусь. Москва, 1976. 260 с.

3. Конституція України, Конституція, Закон від 28.06.1996 № 254к/96-BP, URL: https://zakon.rada.gov.ua/laws/show/254.

4. Загальна декларація прав людини. URL: https://zakon.rada.gov.ua/laws/ show/995_015?lang=uk\#Text.

5. Міжнародний пакт про громадянські i політичні права. URL: https:/ / zakon.rada.gov.ua/laws/show/995_043\#Text

6. Абознова О.В. Суд в механизме реализации права на судебную защиту в гражданском и арбитражном процессе. URL: https://www.dissercat.com/content/ sud-v-mekhanizme-realizatsii-prava-na-sudebnuyu-zashchitu-v-grazhdanskom-iarbitrazhnom-prot.

7. Ніколаєнко Я.М. Поняття та зміст права на судовий захист: сучасний погляд. Науковий вісник Міжнародного гуманітарного університету. Сер: Юриспруденція. 2014 № 8, с. 45-58.

8. Шевчук. Право на судовий захист в сучасних умовах. URL: http:/ / ...irbis-nbuv. gov.ua > cgi-bin > irbis_nbuv > cgiirbis_64.

9. Конвенція про захист прав людини i основоположних свобод. URL: https://zakon.rada.gov.ua/laws/show/995_004\#Text.

10. Фулей T.I., Кучів О.М. Збірник витягів з рішень Європейського суду з прав людини, рекомендованих для вивчення при підготовці до письмового анонімного тестування у межах іспиту для кваліфікаційного оцінювання суддів на відповідність займаній посаді. 2018. 350 с. 
УДК 342.1

DOI https:// doi.org/10.32850/LB2414-4207.2020.14.03

\title{
ФОРМУВАННЯ СОЦАЛЬНОЇ СПРАВЕДЛИВОСТІ ВІД ЕПОХИ АНТИЧНОСТІ ДО ЕПОХИ ВІДРОДЖЕННЯ
}

\author{
Даніліна Марія Ігорівна, \\ аспірант кафедри конституційного \\ права \\ (Національний університет «Одеська \\ юридична академія», м. Одеса, Україна)
}

Статтю присвячено формуванню соціальної справедливості від епохи античності до епохи відродження. Вплив справедливості на формування соціальної держави та ії роль у життєдіяльності суспільства зрозуміли ще в стародавній грецькій філософії. Соціальна справедливість усе більш актуалізується як політична та соціальна категорія, що відповідає новій соціально-політичній орієнтації України як демократичної, соціальної, правової держави, глибинним економічним та соціально-політичним перетворенням, що у ній відбуваються. Поняття справедливості Платон поширив на процес державотворення. Великому Аристотелю належить поняття «загальна справедливість». Аристотель розрізняє два види справедливості як способів розподілу соціальних благ: комутативна та дистрибютивна, або розподільча та компенсаторна (урівнююча) відповідно. У Діонісія Ареопагіта проблема справедливості пов'язана з ідеєю рівності та ієрархії, ці поняття названі божественними. Християнський філософ і теолог Аврелій Августин поділяв думки Платона, що справедливість є благом і іiі сутність полягає в тому, щоб «надати кожному те, що належить йому. Тома Аквінський ставився до душі як до форми тіла, яка позбавлена дару безпосереднього споглядання Бога й Божественних ідей, проте для неї відкритий шлях раціонального пізнання. Тома Аквінський розглядав справедливість як постійне прагнення віддавати кожному належне. За Аквінським, одне з основних гасел єретичних рухів була ідея рівності в Христі, що тлумачиться як заперечення станових привілеїв, засудження приниженого становища селян. Епоха Відродження змінила онтологічні умови буття людини: 3'являється приватна власність і, як наслідок, економічна експлуатація та соціальне розшарування суспільства. В епоху Відродження людина стала вищою цінністю та онтологічною реальністю. Ідеї лібералізму, парламентаризму, конституціоналізму, прав людини стали продовженням у праві ідеї справедливості. Стрімкий розвиток природознавства також вплинув на концепцію справедливості, заклавши в їі основу універсальні докази геометрії та математичну точність і достовірність результатів перед моральною.

Ключові слова: соціальна справедливість, соціальна держава, суспільне буття, античність, середньовіччя, відродження. 


\title{
FORMATION OF SOCIAL JUSTICE FROM ANTIQUITY TO THE RENAISSANCE
}

\author{
Danilina Maria Ihorivna, \\ Graduate Student at the Department of \\ Constitutional Law \\ (National University "Odessa Law \\ Academy", Odesa, Ukraine)
}

The article is devoted to the formation of social justice from antiquity to the Renaissance. The influence of justice on the formation of the welfare state and its role in society was understood in ancient Greek philosophy. Social justice is increasingly relevant as a political and social category that corresponds to the new socio-political orientation of Ukraine as a democratic, social, legal state, the deep economic and socio-political transformations that take place in it. Platon extended the concept of justice to the process of state formation. The great Aristotle has the concept of "universal justice". Aristotle distinguishes between two types of justice as ways of distributing social benefits: commutative and distributive, or - distributive and compensatory (equalizing) respectively. In Dionysius the Areopagite, the problem of justice is related to the idea of equality and hierarchy, these concepts are called divine. Christian philosopher and theologian Aurelius Augustine shared Platon's view that justice is a good and its essence is to "give everyone what belongs to him. Thomas Aquinas treated the soul as a form of the body, which is deprived of the gift of direct contemplation of God and divine ideas, but for him the way of rational knowledge is open. Thomas Aquinas saw justice as a constant desire to pay tribute to everyone. According to Aquinas, one of the main slogans of heretical movements was the idea of equality in Christ, which is interpreted as a denial of class privileges, condemnation of the humiliated position of the peasants. The Renaissance changed the ontological conditions of human existence: private property emerged and, as a result, economic exploitation and social stratification of society. In the Renaissance, man became the highest value and ontological reality. The ideas of liberalism, parliamentarism, constitutionalism, and human rights became a continuation of the idea of justice in law. The rapid development of science has also influenced the concept of justice, based on universal proofs of geometry and mathematical accuracy and reliability of results before the moral.

Key words: social justice, social state, social existence, antiquity, Middle Ages, Renaissance.

Вступ. Питання справедливості в контексті морального виміру, а також формування політичних відносин завжди було важливим у різні періоди історії людства. Проте не завжди однозначно розумілись підходи до сутності передумов та принципів втілення справедливості у суспільно-політичному вимірі життя суспільства та, відповідно, участі у ньому людини.

В історії розвитку людської цивілізації поняття справедливості мало різне значення - етичне, політичне, юридичне - і використовувалося для закріплення політичного, морального, юридичного ставлення людини до дійсності.

Нині соціальна справедливість усе більш актуалізується як політична та соціальна категорія, що відповідає новій соціально-політичній орієнтації України як демократичної, соціальної, правової держави, глибинним економічним та соціально-політичним перетворенням, що у ній відбуваються.

Останнім часом у трактуванні соціальної політики переважають терміни соціальної рівності (нерівності), що очевидно пов' язано з актуалізацією проблематики соціальної справедливості. 
Питання поняття, сутності та концепції справедливості знайшли своє відображення у дисертаціях М.В. Сабадухи «Соціальна справедливість як підгрунтя формування громадянського суспільства: соціально-філософський аналіз»; П.М. Корнєвої «Принцип справедливості у праві соціального забезпечення»; Г.Р. Заремба-Косович «Специфіка уявлень про соціальну справедливість серед українських трудових мігрантів»; В.В. Сокуренка «Роль соціальної справедливості в розбудові правової соціальної держави» та в працях таких вчених, як І.Г. Бабич, В.Д. Бабкіна, М.В. Вітрука, Р.А. Калюжного, М.І. Козюбри, І.М. Луцького, О.Г. Мурашина, Н.М. Оніщенко, П.М. Рабіновича., В.В. Самохвала та інших науковців.

Ця проблематика залишається актуальною через неоднозначність підходів до іiі дослідження.

Метою статті $є$ дослідження основних теорій та підходів поняття соціальної справедливості у філософській думці мислителів та філософів в різні епохи людства та виокремити їх особливості.

Виклад основного матеріалу. Вплив справедливості на формування соціальної держави та іiі роль у життєдіяльності суспільства зрозуміли ще в стародавній грецькій філософії. Держава має діяти в інтересах громадян згідно з принципом справедливості. Так, поняття справедливості Платон поширив на процес державотворення. Він уважав справедливість однією з чеснот поряд із мудрістю, мужністю та розсудливістю [1, с. 122-123]. Платон стверджував: «Щоб осягнути сутність справедливості і благої, праведного життя, необхідно піднятися над забобонами і рутиною повсякденності». Можна сказати, що він правий частково. Якщо моральні міркування діалектичні, якщо в цих роздумах ми ходимо від одних суджень, зроблених в конкретних ситуаціях, до інших таких же міркувань і до принципів, які визначають ці судження, необхідні думки і переконання, нехай неповні і наївні, такі як земля і зерно. Філософія, не зачеплена тінями на стіні, може принести лише марну утопію.

Іншим великим філософом античності, якому належить вагомий внесок у розуміння принципів справедливості у суспільному устрої, є Аристотель. Він був учнем Платона, проте мав свою незалежну думку, яку не боявся висловлювати. Зокрема, відомим є його вислів: «Платон мені друг, але істина дорожча».

Великому Аристотелю належить поняття «загальної справедливості». Зокрема, іï розгляду він відводить цілу п'яту книгу «Нікомахової етики». Зокрема, він зазначає, що загальна справедливість - найвища з чеснот. Це навіть не окрема чеснота, а ознака гармонійного єднання всіх інших чеснот [2, с. 59].

Також Аристотель розрізняє два види справедливості як способів розподілу соціальних благ: комутативна та дистрибютивна, або розподільча та компенсаторна (урівнююча) відповідно. Перша з них належить до ситуацій розподілу благ залежно від статусу (гідності), а друга - до різноманітних ситуацій обміну (наприклад, справедливість в контексті купівлі-продажу) [3, с. 100].

У своєму трактаті «Політика» Аристотель вчить, що справедливість полягає в наділенні людей тим, на що вони заслуговують. А для того, щоб вирішити хто чого вартий, хто на що заслуговує, варто визначити, які доброчесні заслуговують почестей і винагород. Аристотель стверджував, що зрозуміти, який саме пристрій є справедливим, неможливо, якщо спочатку не поміркувати про найбажаніший спосіб життя [4, с. 46].

За Аристотелем, закон не може бути нейтральним у питаннях гарного життя. Навпаки, політичні мислителі сучасності, починаючи з Іммануїла Канта в XVIII ст. і завершуючи Джоном Роулзом в XX ст., стверджують, що принципи справедливості, що визначають наші права, не повинні грунтуватися на якійсь певній концепщії доброчесності або кращого способу життя. Замість цього справедливе суспільство поважає свободу кожного індивідуума вибирати собі концепцію хорошого життя [5, с. 47]. 
У Діонісія Ареопагіта проблема справедливості пов'язана з ідеєю рівності та ієрарxiї, ці поняття названі божественними [6, с. 489]. Позитивом роздумів було те, що проблему справедливості мислитель розглядав у зв'язку з іншими фундаментальними принципами суспільного буття - 3 рівністю та ієрархією.

У підгрунті середньовічної філософії лежали чіткі метафізичні засади - Бог і християнські цінності. У Середньовіччі проблему справедливості досліджували Аврелій Августин, Тома Аквінський, Ансельм Кентерберійський, Бонавентура, Григорій Ниський та інші. Так, християнський філософ і теолог Аврелій Августин поділяв думки Платона, що справедливість є благом [7, с. 516] і ії сутність полягає в тому, щоб «надати кожному те, що належить йому» [8, с. 325]. Уся складність зазначеного підходу в тому, як розуміти належне. Найчастіше це поняття отримує суб'єктивне трактування, яке видають за об'єктивне. Богослов поділяв душу людини на три частини: перша - гнів, друга - хіть, третя - розум, й уважав, що коли перші дві підкоряються третій, то така людина є справедливою [9, с. 38]. Августин Блаженний стверджував, що людина є справедливою не лише під тиском, а в неї має бути розвинене почуття справедливості.

Першу філософсько-правову концепцію з позицій християнства правди та справедливості розробив Тома Аквінський (1226-1274 рр.). На відміну від Августина Блаженного, для якого людська душа була незалежною від тіла духовною субстанцією, здатною безпосередньо спілкуватися з Богом, Тома Аквінський ставився до душі як до форми тіла, яка позбавлена дару безпосереднього споглядання Бога й Божественних ідей, проте для неї відкритий шлях раціонального пізнання. Якщо для Августина Блаженного головне - свобода волі, для Томи Аквінського - розум, який є основою свободи й зумовлює пізнавальну діяльність [10, с. 26].

Тома Аквінський розглядав справедливість як постійне прагнення віддавати кожному належне. Ставлення до права він нерозривно пов'язував 3 рівністю, точніше 3 рівновагою дії кожного стосовно іншого. Філософ, майже повністю відтворивши вчення Аристотеля щодо справедливості, розвинув думки святого Августина про «Град Божий» як ії осередок. Він визначав справедливість як відповідність природному закону, який відображає мудрість у людському розумі як чесноту, що лежить в основі відносин між людьми.

Значну увагу Тома Аквінський приділяє обгрунтуванню станової нерівності. Одним з основних гасел єретичних рухів була ідея рівності в Христі, що тлумачиться як заперечення станових привілеїв, засудження приниженого становища селян. Для обгрунтування їх феодальної залежності використовувалися не лише тексти Святого Письма, звернені до рабів, а й усі аргументи на захист рабства, створені до того ідеологією експлуататорських класів.

Епоха Відродження змінила онтологічні умови буття людини: 3'являється приватна власність i, як наслідок, економічна експлуатація та соціальне розшарування суспільства. Це поставило під сумнів християнські уявлення про справедливість, що діяли в умовах середньовічного суспільства, а тому виникла потреба переосмислення іiі змісту. Філософи-утопісти Т. Мор та Т. Кампанелла першими відреагували на зміни в соціально-економічних умовах життя і на порушення принципів справедливості.

В епоху Відродження людина стала вищою цінністю та онтологічною реальністю [11, с. 43]. Ідеї лібералізму, парламентаризму, конституціоналізму, прав людини стали продовженням у праві ідеї справедливості.

Актуалізувалася необхідність розширення знань про справедливість у ії вже не просто світоглядному контексті, а у правовому, зокрема у контексті їі функціональної ролі в системі правового регулювання. 
Загалом ця епоха заклала нове бачення ідеї справедливості, яка значно відрізнялася від усіх попередніх.

Стрімкий розвиток природознавства також вплинув на концепцію справедливості, заклавши в іï основу універсальні докази геометрії та математичну точність і достовірність результатів. Представниками таких нових ідей вважаються Р. Декарт, Б. Спіноза, Пуфендорф.

Т. Мор виділив такі риси ідеального суспільства: шестигодинний робочий день [12, с. 58], справедливий розподіл суспільного добра [13, с. 110], демократична республіка [14, с. 57], турбота громадян про інтереси суспільства [15, с. 75], активна участь жінок у громадському житті [16, с. 100]. Мислитель обгрунтовує доцільність такого суспільного ладу тим, що він позбавляє громадян рабства, вивільняючи більше часу для освіти, що веде до щасливого життя.

I. Кант, в роботах якого можна побачити підсумки філософського розвитку ідеї справедливості за період XVI-XVIII століть, вперше виокремив моральну і правову справедливість, визнаючи при цьому першість правової справедливості перед моральною [17, с. 402-406].

Висновки. Аналіз проблеми справедливості в історії соціально-філософської думки доводить, що справедливість пов'язують 3 людськими якостями, зокрема 3 внутрішньою сутністю людини, iї здатністю діяти відповідно до належного. Уявлення людей про справедливість як морально-правову категорію, поняття про належне змінювалися протягом всієї історії залежно від змін, які відбувалися у свідомості суспільства стосовно уявлення про невіддільні права людини (вплив філософії природно-космічного життя, християнської доктрини, ідей антропоцентризму тощо). Попри різні підходи до розуміння справедливості, вона є фундаментальним принципом суспільного буття.

\section{Список використаних джерел:}

1. Платон. Держава / пер. 3 давньогр. Д. Коваль. Київ : Основи, 2005. С. 122-123.

2. Аристотель. Никомахова этика. Сочинения в 4 т. Т. 4 / пер. с древнегреч.; общ. ред. А. И. Доватура. Москва: Мысль, 1983. С. 59.

3. Никомахова этика. Пер. Нина Брагинская. Изд-во : ЗАО «Эксмо - Пресс». Москва, 1997. С. 100

4. Арістотель. Політика / пер. 3 давньогр. та передм. О. Кислюка. Київ : Основи. 2005. C. 46.

5. Арістотель. Політика / пер. 3 давньогр. та передм. О. Кислюка. Київ : Основи. 2005. C.47.

6. Дионисий Ареопагит Сочинения. Толкование Максима Исповедника. Санкт-Петербург : Алетейя, 2003. С. 489.

7. Августин А. О граде Божием. Кн. I-XIII. T. 3 / сост. и подг. текста к печати С. И. Ефремова. Санкт-Петербург: Алетейя. Киев: УЦИММ-Пресс, 1998. С. 516.

8. Августин А. О граде Божием. Кн. XIV-XXII. T. 4 / сост. и подг. текста к печати С. И. Ефремова. Санкт-Петербург : Алетейя. Киев : УЦИММПресс, 1998. С. 325.

9. Августин А. О граде Божием. Кн. XIV-XXII. T. 4 / сост. и подг. текста к печати С. И. Ефремова. Санкт-Петербург : Алетейя. Киев : УЦИММПресс, 1998. С. 38.

10. Майк Ю. Соціальні вчення католицької церкви. Досвід історичного аналізу. / Ю. Майк. Рим, Люблін, 1994. С. 26.

11. Філософія: навч. посіб. / Л. В. Губерський, І. Ф. Надольний, В. Пандрущенко та ін.; за ред. І. Ф. Надольного. 2-е вид., перероб. і доп. Київ : Вікар, 2001. С. 43.

12. Мор Т. Утопія. Мор Т. Утопія. Кампанелла Т. Місто Сонця / пер. 3 лат., вст. слово Й. Кобова, Ю. Цимбалюка. Київ : Дніпро, 1988. С. 58. 
13. Мор Т. Утопія. Мор Т. Утопія. Кампанелла Т. Місто Сонця / пер. 3 лат., вст. слово Й. Кобова, Ю. Цимбалюка. Київ : Дніпро, 1988. С. 110.

14. Мор Т. Утопія. Мор Т. Утопія. Кампанелла Т. Місто Сонця / пер. 3 лат., вст. слово Й. Кобова, Ю. Цимбалюка. Київ : Дніпро, 1988. С. 57.

15. Мор Т. Утопія. Мор Т. Утопія. Кампанелла Т. Місто Сонця / пер. 3 лат., вст. слово Й. Кобова, Ю. Цимбалюка. Київ : Дніпро, 1988. С. 75

16. Мор Т. Утопія. Мор Т. Утопія. Кампанелла Т. Місто Сонця / пер. 3 лат., вст. слово Й. Кобова, Ю. Цимбалюка. Київ : Дніпро, 1988. С. 100.

17. История политических и правовых учений / подобщ. ред. академика РАН, д. ю. н., проф. В.С. Нерсесянца. Москва : Издательство НОРМА (Издательская группа НОРМА ; ИНФРА-М), 2000. С. 402-403. 
УДК 340.113

DOI https:// doi.org/10.32850/LB2414-4207.2020.14.04

\title{
СУТНІСТЬ ЮРИДИЧНИХ КАТЕГОРІЙ «ОХОРОНА», «ЗАХИСТ» ТА «ОБОРОНА»: ОСОБЛИВОСТІ ЇХ ВИКОРИСТАННЯ У ЗАКОНОДАВСТВІ УКРАЇНИ
}

\author{
Зіньковський Андрій Сергійович, \\ старший викладач кафедри спеціальної \\ фізичної та вогневої підготовки \\ (Херсонський факультет Одеського \\ державного університету \\ внутрішніх справ, \\ м. Херсон, Україна)
}

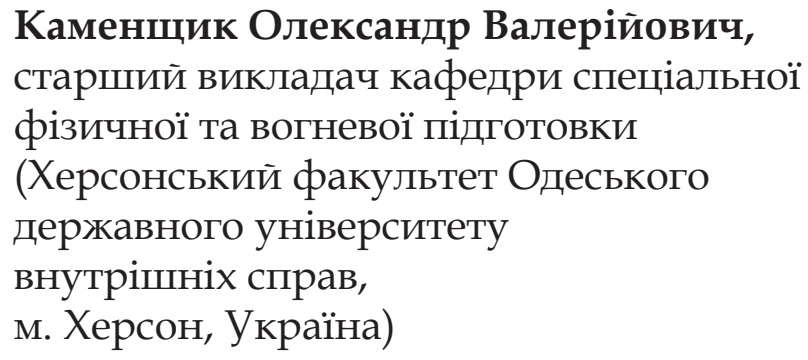

У роботі розглянуто значення деяких юридичних категорій, котрі часто використовуються поліцейськими під час характеристики оперативно-службової діяльності органів і підрозділів Національної поліції України, а також входять до складу категоріального апарату в галузі теорії держави й права.

Проаналізовано значення термінів «оборона», «захист» та «охорона», визначено особливості їх застосування під час опису конкретних фахових ситуацій у контексті розгляду проблем захисту прав і свобод людини й громадянина чи інших суб'єктів права стосовно забезпечення національної безпеки, незалежності й державного суверенітету України.

Спираючись на нормативно-правові акти й суміжні довідникові джерела, проаналізовано основі концептуальні положення, які пов' язані $з$ порядком застосування вищезазначених категорій у чинному законодавстві.

Схарактеризовано особливості застосування категорії «захист» як місця, предмету, споруди, де можна захиститися від кого- або чого-небудь (захисні властивості, індивідуальні засоби захисту).

Термін «оборона» розглядається в таких аспектах, як дія за значенням «обороняти» й «оборонятися»; обстоювати, захищати когось, щось; сукупність засобів, необхідних для безпеки, захисту країни; сторона, яка відстоює інтереси обвинувачуваного під час суду.

Термін «охорона» використовується в процесі розгляду питань, пов' язаних із такими аспектами, як:

1) підтримання нормальних умов функціонування людини, суспільства чи держави, турботою про життя та здоров'я людей, запобігання (попередження) появі можливостей щодо порушення конституційних прав і свобод громадян (профілактика нещасних випадків, травматизму тощо);

2) забезпечення встановленого громадського порядку й організації трудової діяльності (публічної безпеки, безпечних умов на робочому місці й інше); 
3) вжиття організаційно-технічних та інших заходів щодо уникнення потенційного погіршення безпечних умов.

За результатами дослідження зроблено такі узагальнення:

1) терміни «оборона», «охорона» й «захист» стосовно прав і свобод людини й громадянина чи інших суб'єктів права, а також слова й словосполучення, котрі містять зазначені категорії, можуть вживатися у вітчизняному законодавстві в широкому й у вузькому значеннях;

2) у широкому значенні вказані вище терміни, а також слова й словосполучення, до складу котрих вони входять, можуть або ототожнюватися між собою, або співвідноситися як загальне й окреме;

3) у вузькому значенні категорії «оборона», «охорона» й «захист», а також слова й словосполучення, до складу котрих вони входять, розмежовуються між собою, оскільки відбивають різні аспекти діяльності уповноважених суб' єктів.

Ключові слова: теорія держави й права, категорії «оборона», «охорона», «захист», зміст норми права, особливості застосування, нормативно-правові акти, чинне законодавство, правоохоронна діяльність, Міністерство Внутрішніх Справ України.

\title{
ESSENCE OF LEGAL CATEGORIES “PROTECTION", "SECURITY" AND "DEFENSE": FEATURES OF THEIR USE IN THE LEGISLATION OF UKRAINE
}

\author{
Zinkovskyj Andrij Serhijovych, \\ Senior Lecturer at the Department of \\ Special Physical and Fire Training \\ (Kherson Faculty of the Odessa State \\ University of Internal Affairs, \\ Kherson, Ukraine)
}

\author{
Kamenshchyk Oleksandr Valerijovych, \\ Senior Lecturer at the Department of \\ Special Physical and Fire Training \\ (Kherson Faculty of the Odessa State \\ University of Internal Affairs, \\ Kherson, Ukraine)
}

The paper considers the importance of some legal categories that are often used by police officers in characterizing the operational and service activities of bodies and units of the National Police of Ukraine, as well as part of the categorical apparatus in the field of theory of state and law.

The meaning of the terms defense, protection and security is analyzed, the peculiarities of their application in describing specific professional situations in the context of consideration of problems of protection of human and civil rights and freedoms or other subjects of law in relation to national security, independence and state sovereignty of Ukraine.

Based on regulations and related reference sources, the conceptual provisions related to the application of the above categories in the current legislation are analyzed.

Features of application of the category "protection" as a place, subject, construction where it is possible to be protected from someone or something (protective properties, individual means of protection) are characterized.

The term "defense" is considered in such aspects as the action on the meaning of to defend and to be defended; to protect someone, something; a set of tools necessary for security, defense of the country; the party defending the interests of the accused during the trial. 
The term "security" is used when considering issues related to such aspects as: 1) maintenance of normal conditions for the functioning of man, society or the state, concern for human life and health, prevention (warning) of opportunities for violations of constitutional rights and freedoms of citizens (prevention of accidents, injuries, etc.); 2) ensuring the established public order and organization of labor activity (public safety, safe working conditions, etc.); 3) taking organizational, technical and other measures to avoid potential deterioration of safe conditions.

According to the results of the study, the following generalizations were made: 1$)$ the terms "defense", "security" and "protection" in relation to human and civil rights and freedoms or other subjects of law, as well as words and phrases containing these categories may be used in domestic legislation in the broad and narrow meanings; 2) in a broad sense, the above terms, as well as the words and phrases which consist them, can either be identified with each other, or correlated as general and separate; 3) in the narrow sense the categories "defense", "security" and "protection", as well as the words and phrases which consist them, are distinguished from each other, as they reflect different aspects of the activities of authorized entities.

Key words: theory of state and law, categories defense, security, protection, content of the rule of law, features of application, normative legal acts, current legislation, law enforcement activity, MIA of Ukraine.

Постановка проблеми у загальному вигляді та їі зв'язок із важливими науковими чи практичними завданнями. Під час створення чи користування нормативно-правовими актами законодавства України, а також у теорії правових наук у цілому фахівцям-юристам доцільно уникати застосування тотожних категорій, котрі мають різні назви, але однакову чи подібну сутність (зміст). Для чіткого й однозначного опису юридичного факту кожна правова категорія повинна мати тільки власне наповнення, свій індивідуальний смисл і значення, тобто вона повинна відрізнятися від іншого аналогічного терміну, котрий застосовується в галузі юриспруденції. У протилежному випадку це призводить до створення суперечностей у процесі побудови логіки суджень і сприяє виникненню утруднень під час сприйняття юристами (читачами) текстового матеріалу документу, перевантаженості норм права тотожними правовими категоріями тощо.

Аналіз досліджень і публікацій, в яких започатковано розв'язання проблеми. У теорії права стосовно вищезазначених понять існують різноманітні думки. Одні вчені вважають ці категорії абсолютними синонімами, інші - стверджують про їхню самостійність і недоцільність ототожнення, треті - стверджують про їхнє співвідношення між собою як загальне й одиничне (особливе). Ці дискусії й досі тривають у теорії права на методологічному рівні.

Відповідно до визначень, наведених у Сучасному тлумачному словнику української мови, слово «охорона» використовується в контексті таких значень:

1) оберігання від знищення, пошкодження, небезпеки (надійна охорона);

2) загін, що оберігає, охороняє, забезпечує щось (особиста охорона Президента) [1, c. 336].

Слово «захист» розуміється в таких значеннях:

1) охорона, заступництво (захист прав споживачів);

2) відстоювання на суді інтересів обвинуваченого (адвокат грамотно побудував захист);

3) місце, предмет, споруда, де можна захиститися від кого- або чого-небудь (відшукати захист від зливи, індивідуальні засоби захисту) [1, с. 192]. 
Слово «оборона» розглядається в таких аспектах:

1) дія за значенням обороняти й оборонятися;

2) заступництво, підтримка; захист; брати (взяти) під [свою] оборону кого, що; виступати (виступити) в оборону кого, чого; ставити (стати) в оборону кого, чого заступатися за кого-, що-небудь; обстоювати, захищати когось, щось;

3) сукупність засобів, необхідних для безпеки, захисту країни;

4) вiйськ. - система вогневих точок, укріплень і таке інше, на якій розміщуються війська, готуючись відбити напад противника; займати (зайняти) оборону - відповідним розміщенням військ, вогневих засобів і таке інше готуватися до відбиття атаки, нападу противника; стояти в обороні - займати яку-небудь позицію з відповідним розміщенням вогневих засобів перед можливим нападом противника;

5) юр. - сторона, яка відстоює інтереси обвинувачуваного під час суду [1, с. 334].

О.Ф. Скакун, визначаючи основні функцій держави, виділяє серед них такі:

1) правоохоронну - попередження посягання на конституційний лад, права і свободи громадян, забезпечення охорони правового порядку, закріплених у нормах права суспільних відносин;

2) правозахисну - забезпечення захисту регульованих нормами права суспільних відносин від будь-яких посягань, відновлення правового стану суб'єктів права, інтересів суспільства, правової законності й правового порядку в разі їх порушення;

3) функцію оборони держави - захист воєнної безпеки, територіальної цілісності й недоторканості держави, державного суверенітету від зовнішніх зазіхань як економічними, дипломатичними, так і військовими способами; [2, с. 133].

Навіть в описі цих функцій бачимо, що під час характеристики функції оборони автором було вжито термін «захист».

У багатьох нормативно-правових актах чинного законодавства України вищезазначені терміни використовуються та мають різні або тотожні значення, зокрема, у Конституції України [3], Законі України «Про Національну поліцію України» [4], галузевих кодексах тощо.

Виділення невирішених раніше частин загальної проблеми, котрим присвячується означена стаття. Провівши аналіз практики застосування вищезазначених категорій у вітчизняному законодавстві, можемо констатувати, що в теорії та практиці нормотворчості не виключено використання широких (узагальнених) категорій, котрі підпорядковують собі як складові елементи дрібніші елементи соціальних явищ чи процесів, які регулюються в нормативному акті. Не $є$ винятками й такі поняття, як «оборона», «охорона» й «захист», котрі вживаються в контексті характеристики не тільки прав і свобод людини й громадянина, а й функціонування інших суб'єктів права - держави, правоохоронних органів, поліцейських тощо, а також у разі використання цих дефініцій у поєднанні з іншими термінами або словосполученнями. Таким чином, існування цих та інших протиріч обумовлює додаткове дослідження порядку застосування категорій «охорона», «захист» та «оборона» в нормотворчій та правоохоронній діяльності.

Метою роботи є:

1) аналіз ситуацій щодо застосування термінів «охорона», «захист» та «оборона» в різногалузевих нормативних актах українського законодавства;

2) уточнення випадків неоднакового вживанні законодавцем цих термінів стосовно забезпечення гарантій держави в частині дотримання прав і свобод людини й громадянина з боку правоохоронних органів країни в ряді кодифікованих законів України;

3) узагальнення практики застосування термінів «оборона», «охорона» й «захист» стосовно прав і свобод людини й громадянина чи інших суб'єктів права, зокрема використання їх у широкому й у вузькому значеннях. 
Виклад основного матеріалу дослідження. Проаналізуємо можливі випадки використання законодавцем термінів «охорона», «захист» та «оборона»у різногалузевих нормативних актах чинного українського законодавства.

За результатами вибіркового аналізу деяких законів України можна побачити, що термін «охорона» часто вживається в одному контексті з такими термінами, як «оборона» й «захист», тобто законодавцем під час їхнього застосування в багатьох нормативних актах суттєво не акцентується увага на їх змістовних відмінностях.

Так, відповідно до статті 1 «Призначення та завдання Національної гвардії України» (далі - НГУ) Закону України (далі - ЗУ) «Про Національну гвардію України» такий орган є військовим формуванням з правоохоронними функціями, що входить до системи Міністерства внутрішніх справ України (далі - МВС України) й призначений для виконання завдань із захисту й охорони життя, прав, свобод і законних інтересів громадян, суспільства й держави від злочинних та інших протиправних посягань, охорони громадського порядку й забезпечення громадської безпеки, а також у взаємодії з правоохоронними органами - із забезпечення державної безпеки й захисту державного кордону [5].

НГУ бере участь відповідно до закону у взаємодії зі Збройними Силами України (далі - 3СУ) у виконанні завдань територіальної оборони [5].

У статті 2 цього Закону законодавець під час визначення основних функцій НГУ використовує всі три терміни:

1) захист конституційного ладу України, цілісності ї̈ території від спроб зміни їх насильницьким шляхом;

2) охорона громадського порядку, забезпечення захисту й охорони життя, здоров'я, прав, свобод і законних інтересів громадян;

3) участь у забезпеченні громадської безпеки й охороні громадського порядку під час проведення масових заходів, що створюють небезпеку для життя та здоров'я громадян;

4) забезпечення охорони органів державної влади, перелік яких визначається Кабінетом Міністрів України (далі - КМУ), ядерних установок і матеріалів, радіоактивних відходів, інших джерел іонізуючого випромінювання державної власності;

5) охорона спеціальних вантажів, перелік яких визначається КМУ, дипломатичних представництв, консульських установ іноземних держав, представництв міжнародних організацій в Україні; центральних баз матеріально-технічного забезпечення МВС України;

6) оборона важливих державних об' єктів, спеціальних вантажів, переліки яких визначаються Президентом України, КМУ й МВС України [5].

Стаття 24 Конституції України гарантує, що «<..> рівність прав жінки й чоловіка забезпечується: спеціальними заходами щодо охорони праці й здоров'я жінок <...>; правовим захистом, матеріальною та моральною підтримкою материнства й дитинства <..>» [3]. Стаття 34 Основного Закону гарантує, що «здійснення громадянами прав на свободу думки й слова, на вільне вираження своїх поглядів і переконань може бути обмежене законом <..> для охорони здоров'я населення, для захисту репутації або прав інших людей <...> [3].

Захист державної безпеки прямо пов'язаний із захистом державного кордону України. Забезпечення цілісності й недоторканності державного кордону України $\epsilon$ конституційною вимогою (стаття 2 Конституції України), обов'язок за реалізацією якої покладається відповідно до Закону України від 4 листопада 1991 р. «Про державний кордон України» на ЗСУ й відповідні військові формування [6, с. 91]. Охорона державного кордону України на суші, морі, річках, озерах та інших водоймах 
покладається на Державну прикордонну службу України, а в повітряному й підводному просторі в межах територіального моря - на 3СУ (3У «Про державний кордон України», «Про Державну прикордонну службу України», «Про оборону України», «Про 3бройні Сили України» й інші) [6, с. 92].

Законодавство України передбачає, що в забезпеченні державної безпеки й захисті державного кордону в межах своєї компетенції також беруть участь:

1) поліція, яка діє згідно з Законом України від 02 липня 2015 р. «Про Національну поліцію»;

2) НГУ, правовий статус котрої визначено в Законі України від 13 березня 2014 р. № 876-VII «Про Національну гвардію України» [5].

Таким чином, термін «охорона» використовується у випадках, коли йдеться про забезпечення та підтримання нормальних умов функціонування людини, суспільства чи держави, турботу про життя та здоров'я людей, запобігання (попередження) появі можливостей щодо порушення конституційних прав і свобод громадян (профілактика нещасних випадків, травматизму тощо), забезпечення встановленого правопорядку (публічного порядку, на робочому місці й інше), вжиття організаційно-технічних та інших заходів щодо уникнення потенційного погіршення безпечних умов.

Термін «захист» використовується стосовно характеристики заходів, котрі вживаються для забезпечення (відновлення) порущених конституційних прав і гарантій як фізичних, так і юридичних осіб в різних аспектах їхньої життєдіяльності.

Так, в статті 8 Конституції України закріплено таке положення: «Звернення до суду для захисту конституційних прав і свобод людини й громадянина безпосередньо на підставі Конституції України гарантується» [3]. Такі звернення можливі не тільки для захисту, але й для сприяння здійсненню та для охорони конституиійних прав [6, с. 50]. Стаття 13 Конституції України передбачає норму, згідно з якою «держава забезпечує захист прав усіх суб'єктів права власності й господарювання <...>» [3], тобто гарантує всім суб'єктам права власності рівність перед законом [6, с. 72].

Частина 5 статті 17 Конституції України встановлює обов'язок держави щодо забезпечення соціального захисту громадян України, які перебувають на службі в ЗСУ й в інших військових формуваннях, а також членів їхніх сімей. Фундаментальним правовим підгрунтям для закріплення цього обов' язку держави є визнання Конституцією України людини найвищою соціальною цінністю (стаття 3), проголошення України соціальною державою (преамбула, стаття 1), гарантування громадянам права на соціальний захист, на рівень життя, не нижчий від прожиткового мінімуму (стаття 46) [3].

У статті 25 Конституції України зазначається, що «<.. > Україна гарантує піклування та захист своїм громадянам, які перебувають за ії межами» [3]. Держава зобов'язана захищати своїх громадян за кордоном, особливо коли виникає загроза їх життю та здоров'ю. Стаття 27 Конституції України гарантує, що «<...> Кожен має право захищати своє життя та здоров' я, життя та здоров' я інших людей від протиправних посягань» [3]. Держава бере на себе певні обов'язки щодо захисту життя. Це випливає з положення статті 27 Конституції про заборону свавільного позбавлення життя; обов' язок держави криміналізувати вбивство, не позбавляти будь-яку особу життя свавільно; відмову від смертної кари як засобу кримінального покарання; заборону екстрадиції особи в державу, в якій до неї може бути застосована смертна кара тощо [6, с. 134]. Стаття 32 Конституції України визначає, що «<..> Кожному гарантується судовий захист права спростовувати недостовірну інформацію про себе й членів своєї сім'ї <...> [3]. У разі порушення цього права особа може оскаржити до суду, а якщо виявиться неправдивість інформації про особу, вона має право спростовувати ії та вимагати інших відповідних засобів захисту (статті 3, 275, 280 Цивільного кодексу України) (далі - ЦКУ) [7]. 
У п. 3 статті 42 «Поліцейські заходи примусу» 3У «Про Національну поліцію» визначається, що «спеціальні засоби як поліцейські заходи примусу - це сукупність пристроїв, приладів і предметів, спеціально виготовлених, конструктивно призначених і технічно придатних для захисту людей від ураження різними предметами (у тому числі від зброї) <...> [4]. У п. 6 цієї статті уточняється, що «не є заходом примусу використання поліцейським засобів індивідуального захисту (шоломів, бронежилетів, протиударних щитів та іншого спеціального екіпірування)» [4]. Відповідно до вимог статті 46 цього Закону «поліцейський уповноважений у виняткових випадках застосовувати вогнепальну зброю - для захисту осіб від нападу, що загрожує їхньому життю чи здоров'ю; для відбиття нападу на об'єкти, що перебувають під охороною, конвої, житлові й нежитлові приміщення, а також звільнення таких об'єктів у разі їх захоплення» [4].

Термін «оборона» часто використовується в нормативно-правових актах в одному контексті 3 термінами «захист» та «охорона». Наприклад, стаття 17 Конституції визначає, що «<...> Оборона України, захист ії суверенітету <...> покладаються на ЗСУ. Забезпечення державної безпеки й захист державного кордону України покладаються на відповідні військові формування та правоохоронні органи держави <...> Держава забезпечує соціальний захист громадян України, які перебувають на службі в ЗСУ й в інших військових формуваннях, а також членів їхніх сімей» [3].

Важливість і складність завдань національної безпеки України викликає необхідність суспільного визнання на рівні Основного Закону захисту суверенітету й територіальної цілісності України обов' язком держави, справою всього народу. Визнаючи захист суверенітету України найважливішою функцією держави, ч. 1 статті 17 Конституції України водночас не вказує, які саме державні органи ії виконують. Коло суб'єктів, на яких покладається виконання цієї функції, можна визначити шляхом тлумачення частин 2-4 статті 17, статей 85, 102, 106, 107, 116 Конституції України, а також статті 4 Закону від 19 червня 2003 р. «Про основи національної безпеки України» [8].

Частина 2 статті 17 Конституції окреслює завдання щодо забезпечення оборони України, яка (оборона - уточнено нами) статтею 1 Закону України «Про оборону України» визначається як система політичних, економічних, соціальних, воєнних, наукових, науково-технічних, інформаційних, правових, організаційних, інших заходів держави щодо підготовки до збройного захисту та ї̈ захист у разі збройної агресії або збройного конфлікту [3; 6].

Стосовно захисту людиною своїх конституційних прав, у кримінальному праві використовується термін «необхідна оборона», під котрою розуміється обставина, що відповідно до закону виключає кримінальну вidnobiдальність особи за шкоду, яку вона заподіяла іншій особі (нападникові). Закріплюючи право громадян на необхідну оборону, держава цим створює умови для своєчасного відвернення шкоди, яка загрожує охоронюваним законом інтересам, для захисту правопорядку, боротьби зі злочинністю.

Отже, термін оборона Використовується 8 нормативно-правових актах $b$ контексті розгляду питань, пов'язаних з активним захистом безпеки людини чи держави (територіальної цілісності, недоторканості держави, державного суверенітету) від зовнішніх посягань різними способами:

1) підготовкою до збройного захисту (демонстрування сили) й адекватним припиненням злочинних дій державою (людиною) в разі збройної агресії або збройного конфлікту;

2) вчиненням необхідних дій під час захисту інтересів держави, публічних інтересів, особи чи прав того, хто обороняється, або іншої людини від суспільно небезпечного посягання шляхом заподіяння нападнику шкоди. 
Необхідно зазначити, що в законодавстві України є й інші норми, в котрих вживаються вищеназвані категорії. Проведений аналіз щодо їхнього використання в Конститущії України й цілого ряду законів показує, що терміни «оборона», «охорона» й «захист» між собою за деякими критеріями не розмежовуються. Це свідчить про те, що ці дефініції вживаються в Основному Законі й багатьох кодифікованих і галузевих нормативно-правових актах як рівнозначні, тобто тотожні між собою. Таким чином, вищенаведені аргументи дозволяють зробити висновок про те, що категорії «оборона», «охорона» й «захист» стосовно прав і свобод людини й громадянина й інших суб'єктів у різних галузях права можуть вживатися в широкому значенні, тобто ототожнюватися між собою.

Водночас необхідно відзначити неоднакове застосування законодавця в разі вживання термінів «оборона», «захист» та «охорона» стосовно забезпечення гарантій держави в частині дотримання прав і свобод людини й громадянина з боку правоохоронних органів країни в ряді кодифікованих законів України.

Так, наприклад, у статті 1 Кодексу України про адміністративні правопорушення (далі - КУАП) зазначається, що його завданням є охорона прав і свобод громадян, власності тощо. Притримуючись строго юридичного підходу, можна зробити логічний висновок, що норми КУАП не захищають права і свободи людини. Але це твердження, на нашу думку, є неправильним висновком [10]. Аналогічна ситуація спостерігається й у Кримінальному кодексі України (далі - ККУ) [9]. Відповідно до частини 1 статті 1 цього кодифікованого нормативного документу його завданням $\epsilon$ правове забезпечення охорони прав і свобод людини й громадянина, власності, громадського порядку й громадської безпеки, довкілля, конституційного устрою України від злочинних посягань, забезпечення миру й безпеки людства, а також запобігання злочинам. Водночас нормами Кодексу також здійснюється і захист прав і свобод особистості. Передбачаємо, що така ситуація 3 використанням термінів «охорона» й «захист» в ККУ, КУАП і ЦПКУ може бути пояснена традицією, яка встановилася в матеріальних галузях права України, коли, за суттю справи, ці терміни фактично та юридично між собою не розмежовуються.

Разом із тим варто відзначити й правильність суджень тих вчених, котрі вважають, що категорії «оборона», «охорона» й «захист» стосовно прав і свобод людини й громадянина доцільно розмежовувати між собою. Водночас ці вчені виходять із діяльнісного (вузького) розуміння сутності названих вище термінів. Так, термін «охорона» прав і свобод людини й громадянина в разі розуміння його у вузъкому значенні вживається в тому випадку, коли діяльність відповідних суб'єктів спрямована на попередження порушень прав і свобод людини й громадянина, тобто коли факти порушення або загрози порушень прав і свобод особистості відсуmні.

Термін «захист прав і свобод людини й громадянина» 3 врахуванням його розуміння у вузькому значенні може вживатися в тому випадку, коли відбулося порущення прав і свобод ююдини й громадянина або існує реальна загроза їх порушенню, а також інші перешкоди в користуванні ними. У такому випадку діяльність відповідних суб'єктів спрямована безпосередньо на відновлення порушених прав і свобод людини й громадянина, а також усунення перешкод у користуванні ними.

Термін «оборона, необхідна оборона» використовується у випадках, коли під час захисту інтересів держави, публічних інтересів, особи чи прав людини, яка обороняється, або іншої людини від суспільно небезпечного посягання заподіюється нападаючому шкода для припинення правопорушення (злочину).

У разі такого підходу до визначення змісту термінів «оборона», «охорона» й «захист» стосовно прав і свобод людини й громадянина вони розуміються в діяльнісному (вузькому) значенні, тобто розмежовуються між собою. 
Як зазначалось вище, для правоохоронних органів захист прав i сbобод ююдини й громадянина є основним видом їхньої діяльності. Водночас сам термін «правоохоронні органи», на думку С.В. Кодавбовича [12, с. 253-257], має подвійне наповнення: з одного боку, такі органи покликані здійснювати охорону прав і свобод людини й громадянина, тобто створювати умови, за яких не допускається їхнє порушення, а з іншого боку, вони зобов' язані здійснювати захист цих прав і свобод людини у випадку їх порушення або загрози порушення, в тому числі сприяти як у відновленні таких прав і свобод, так і в усуненні перешкод у користуванні ними.

Таким чином, категорія «правоохоронний орган» фактично містить поняття державного «правозахисного органу». Як обгрунтування таких аргументів можна навести норми Закону України від 02 липня 2015 р. «Про Національну поліцію України». Так, в частині 1 статті 1 Закону зазначається, що НПУ - це центральний орган виконавчої влади, який служить суспільству шляхом забезпечення охорони прав і свобод людини, протидії злочинності, підтримання публічної безпеки й порядку [4]. Разом із тим у статті 16 «Основних повноважень Міністра внутрішніх справ України у відносинах із поліцією» 3У «Про Національну поліцію» Міністр внутрішніх справ України «<..> забезпечує формування державної політики у сфері забезпечення публічної безпеки й порядку, охорони й захисту прав і свобод людини, інтересів суспільства й держави, а також надання поліцейських послуг і контролює іiі реалізацію поліцією» [4].

Одночасно із цим варто відзначити, що, на нашу думку, поставлені перед НПУ вищезазначені завдання не передбачають тільки виконання вказаним державним органом діяльності, яка пов'язана виключно з відновленням порушених прав, свобод i законних інтересів зазначених вище осіб чи усунення перешкод у користуванні ними вказаними правами й свободами. Діяльність органів і підрозділів НПУ спрямована також на попередження таких порушень або можливості виникнення загрози для конституційних прав і свобод.

Висновки. Провівши в рамках дослідження аналіз різноманітних підходів законодавців щодо використання вищезазначених термінів, на основі наведених нами аргументів можемо зробити деякі узагальнення:

- терміни «оборона», «охорона» й «захист» стосовно прав і свобод людини й громадянина чи інших суб'єктів права, а також слова й словосполучення, котрі містять зазначені категорії, можуть вживатися у вітчизняному законодавстві в широкому й у вузькому значеннях;

- у широкому значенні вказані вище терміни, а також слова й словосполучення, до складу котрих вони входять, можуть або ототожнюватися між собою, або співвідноситися як загальне й окреме;

- у вузькому значенні такі категорії, а також слова й словосполучення, до складу котрих вони входять, розмежовуються між собою, оскільки відбивають різні аспекти діяльності уповноважених суб'єктів.

\section{Список використаних джерел:}

1. Сучасний тлумачний словник української мови / уклад. Л.П. Олексієнко, О.Л. Шумейло). Київ : Кобза, 2002. 544 с.

2. Скакун О.Ф. Теорія права і держави : підручник. Київ : Алерта; КНТ; ЦУЛ, 2009. 520 c.

3. Конституція України : Закон України від 28 червня 1996 року № 254к/96-ВР (зі змінами, внесеними Законом України від 02 червня 2016 року № 1401-VIII) / Верховна Рада України. URL: http://zakon0.rada.gov.ua/laws/show/254к/96-вр. 
4. Про Національну поліцію : Закон України від 2 липня 2015 року № 580-VIII / Верховна Рада Украйни. URL: http://zakon3.rada.gov.ua/laws/show/580-19/conv/page1-4.

5. Про Національну гвардію України : Закон України від 13 березня 2014 року № 876-VII (зі змінами станом на 24 грудня 2015 року) / Верховна Рада України. URL: http:/ / zakon1.rada.gov.ua/laws/show/876-18.

6. Конституція України. Науково-практичний коментар / ред. колегія: д-р юрид. наук В.Я. Тацій (голова редколегіï) та ін. Харків : Право, 2003. 805 с.

7. Цивільний кодекс України : Закон України від 16 січня 2003 року № 435-IV (зі змінами й доповненнями) / Верховна Рада України. URL: https://zakon.rada.gov.ua/ laws/show/435-15\#Text.

8. Про основи національної безпеки України : Закон України від 19 червня 2003 року № 964-IV (станом на 16 липня 2015 року). Голос Украйни. 2003. № 134. 22 липня 2003 року. С. 20-21.

9. Кримінальний кодекс України Закон України від 5 квітня 2001 року № 2341-III (набрав чинності з 1 вересня 2001 року, зі змінами й доповненнями) / Верховна Рада Украӥни. URL: http:/ / zakon.rada.gov.ua/cgi-bin/laws/main.cgi?nreg=2341-14.

10. Кодекс України про адміністративні правопорушення : Закон України від 07 грудня 1984 року № 8073-Х (зі змінами й доповненнями) / Верховна Рада України. URL: http:/ / zakon.rada.gov.ua/cgi-bin/laws/main.cgi?nreg=80731-10.

11. Цивільний процесуальний кодекс України : Закон України від 18 березня 2004 року № 1618-IV. URL: https:/ / zakon.rada.gov.ua/laws/ show/1618-15\#Text

12. Кодавбович С.В. Категории «охрана» и «защита» прав и свобод человека и гражданина в законодательстве Республики Беларусь и правовой науке. Актуальные вопросы современной юридической науки: теория, практика, методика [Электронный ресурс] : сборник материалов II Международной заочной научной конференции, Могилев, 19 мая 2017 года / Министерство внутренних дел Республики Беларусь, учреждение образования «Могилевский институт Министерства внутренних дел Республики Беларусь» ; редкол.: В.Е. Бурый (отв. ред.) и др. Могилев : Могилев. институт МВД, 2017. 1 электрон. опт. диск (CD-R). Загл. с экрана. C. 253-257. 
УДК 340.11

DOI https:// doi.org/10.32850/LB2414-4207.2020.14.05

\title{
ГАРАНТІЇ ЗАХИСТУ ПУБЛІЧНОГО ІНТЕРЕСУ
}

\author{
Золотухіна Лілія Олександрівна, \\ доктор юридичних наук, доцент, \\ завідувач кафедри цивільно-правових \\ дисциплін \\ (Дніпропетровський державний \\ університет внутрішніх справ, \\ м. Дніпро, Україна)
Легеза Юлія Олександрівна, доктор юридичних наук, професор, професор кафедри цивільного, господарського та екологічного права (Національний технічний університет «Дніпровська політехніка», м. Дніпро, Україна)

У статті досліджуються особливості застосування заходів адміністративної відповідальності як гарантії захисту публічного інтересу. Обгрунтовано, що адміністративно-правовий механізм захисту публічних інтересів є теоретичною конструкцією, «ідеальною моделлю», що схематично відбиває нормативне підгрунтя, суб'єктний склад і формальний порядок здійснення адміністративно-правових заходів у полі превентивної охорони, захисту й відновлення порушених публічних інтересів. Підкреслено, що захисна публічно-адміністративна діяльність прямо пов'язана із застосуванням примусових методів; іiі різновидами виступають контрольно-наглядова й превентивна діяльність. Обгрунтовано, що комплексність і складність адміністративно-правового механізму захисту публічного інтересу відбивається на необхідності конкретизації зазначених структурних елементів досліджуваного механізму стосовно певних публічних інтересів, що потребують захисту. Досліджено проблеми застосування заходів адміністративної відповідальності як інструменту захисту публічного інтересу, що полягають насамперед у необхідності визнання суб' єктами адміністративної відповідальності не лише фізичних, а і юридичних осіб і доцільності загального перегляду встановлених законодавством санкцій за правопорушення в досліджуваній сфері, як і їх корекції в частині розмірів штрафу для відповідності до вимог сьогодення. Наголошено на ключовій, визначальній ролі ефективного й налагодженого механізму притягнення до адміністративної відповідальності в загальній системі правового захисту публічних інтересів. Підкреслено, що, виконуючи профілактично-превентивну, виховальну, відновлювальну й карну функції, інститут адміністративної відповідальності становить базис ефективного функціонування всього адміністративно-правового механізму забезпечення реалізації публічних інтересів.

Ключові слова: адміністративний захист, адміністративні правовідносини, адміністративна відповідальність, ознаки, поняття, публічне управління, публічний інтерес. 


\title{
GUARANTEES OF PROTECTION OF PUBLIC INTEREST
}

\author{
Zolotukhina Lilia Oleksandrivna, \\ Doctor of Law, Associate Professor, \\ Head of the Department \\ of Civil Law Disciplines \\ (Dnipropetrovsk State University \\ of Internal Affairs, \\ Dnipro, Ukraine)
}

\author{
Legeza Yuliya Oleksandrivna, \\ Doctor of Law, Professor, Professor, \\ Professor of Civil, Commercial \\ and Environmental Law \\ (National Technical University \\ Dnipro Polytechnic, \\ Dnipro, Ukraine)
}

The article explores the peculiarities of the application of measures of administrative responsibility as a guarantee of protection of public interest. The author substantiates that the administrative-legal mechanism of protection of public interests is a theoretical construction, an "ideal model", which schematically reflects the regulatory basis, the subjective composition and the formal procedure for the implementation of administrative-legal measures in the field of preventive protection and protection and recovery of violated publics. The author emphasizes that protective publicadministrative activity is directly related to the use of coercive methods; its variants are control and surveillance and preventive activities. The author substantiates that the complexity and complexity of the administrative and legal mechanism of protection of public interest reflects on the need to specify these structural elements of the mechanism under study with respect to certain public interests in need of protection. The problems of application of measures of administrative responsibility as a tool of protection of public interest, which are, first of all, need to be recognized by the subjects of administrative responsibility not only individuals but also legal entities and expediency of the general sanctions for offenses in the investigated sphere, as well as their corrections in part, are investigated. the size of the fine to meet the requirements of today. The key, decisive role of an effective and well-established mechanism of administrative liability in the general system of legal protection of public interests is emphasized. It is emphasized that in carrying out preventive-preventive, educational, restorative and punitive functions, the institute of administrative responsibility is the basis for the effective functioning of the whole administrative and legal mechanism of ensuring the realization of public interests.

Key words: administrative protection, administrative legal relations, administrative responsibility, signs, concepts, public administration, public interest.

Постановка проблеми. Проблематика адміністративної відповідальності ніколи не залишалася осторонь дослідницької уваги. У різні роки на порядок денний залежно від суспільного запиту висувалися такі аспекти цієї тематики, як загальне поняття адміністративної відповідальності, іï ознаки й специфічне місце серед інших видів юридичної відповідальності, структура й процесуальні особливості, а також трансформації кола ії суб'єктів. 
Ступінь наукової розробки проблеми. Значний внесок у розробку зазначених питань зробили такі вітчизняні вчені, як В.Б. Авер' янов, Ю.П. Битяк, Т.О. Коломоєць, B.К. Колпаков, А.Т. Комзюк, O.I. Миколенко й інші. Наше наукове завдання полягає в тому, щоб на засаді теоретичних розробок, здійснених указаними вченими, провести діагностику сучасного стану реалізації адміністративної відповідальності у сфері захисту публічних інтересів і виявити аспекти, що потребують доопрацювання з боку адміністративно-правової науки.

Мета статті полягає в здійсненні характеристики гарантій захисту публічного інтересу.

Виклад основного матеріалу. Відсутність законодавчого визначення адміністративно-правової відповідальності спонукає нас до розгляду теоретичних знахідок у цій царині. Розповсюдженим у вітчизняній адміністративно-правовій науці $\epsilon$ підхід, згідно з яким адміністративну відповідальність позначають як окремий вид юридичної відповідальності, якому поряд із загальними ознаками юридичної відповідальності - примусовий характер [1, с. 48], виникнення на підставі вчиненого правопорушення [2, с. 434], застосування до особи-правопорушника санкцій у вигляді позбавлення певних цінностей [3, с. 50] - притаманні власні специфічні риси. Для ïx встановлення здійснимо огляд сучасного теоретико-правового простору в аспекті концептуального змісту категорії адміністративної відповідальності.

Найбільш традиційною у світлі вищезазначеного виглядатиме дефініція адміністративної відповідальності, запропонована Ю.П. Битяком і В.В. Зуєм: це вид юридичної відповідальності, встановлений за порушення адміністративно-правових норм на основі застосування адміністративних стягнень [4, с. 121]. Деталізує це визначення В.Б. Авер'янов, трактуючи адміністративну відповідальність як сукупність адміністративних правовідносин, що виникають у зв'язку із застосуванням уповноваженими органами чи їх посадовими особами до осіб, які вчинили адміністративний проступок, передбачених нормами адміністративного права особливих санкцій адміністративних стягнень [5, с. 430-431].

Як одну з визначальних рис адміністративної відповідальності А.Т. Комзюк називає ії позасудовий характер: хоча в деяких випадках адміністративні стягнення накладаються судовими органами, повноваження щодо застосування цих стягнень надані законодавством багатьом органам управління та їхнім посадовим особам [6, с. 6]. Також дослідник звертає увагу на особливий процедурний порядок притягнення до адміністративної відповідальності; цю думку зустрічаємо також у праці В.К. Колпакова й О.В. Кузьменко, які підкреслюють обов'язкове додержання встановленої процедури в примусовому застосуванні правомочним суб'єктом передбачених законодавством за вчинення адміністративного проступку заходів впливу, виконуваних правопорушником, що й іменується адміністративною відповідальністю [7, с. 252].

Широкий змістовий аналіз адміністративної відповідальності зустрічаємо в дисертаційному дослідженні Л.В. Мілімко. Авторка виділяє такі ознаки адміністративної відповідальності: нормативна визначеність, встановлення виключно законодавчими актами; публічний характер; відповідна процедура реалізації; виступає засобом охорони встановленого державою правопорядку; супроводжується державним і громадським осудом діяння та правопорушника, який його вчинив; об'єктом охорони є суспільні відносини, що відрізняються міжгалузевим правовим регулюванням (саме цей аспект відрізняє адміністративну від цивільно-правової та дисциплінарної відповідальності); настає за вчинення адміністративних проступків; спеціальні повноваження публічних органів та їх посадових осіб, що мають право притягати до адміністративної відповідальності; на винних суб'єктів накладаються адміністративні 
стягнення 3 метою, визначеною ст. 23 Кодексу України про адміністративні правопорушення (далі - КУпАП) (виховання правопорушника й запобігання вчиненню нових правопорушень), а також із метою покарання винного; це примусовий захід, застосування якого спричиняє негативні (моральні або матеріальні) наслідки для правопорушника [8, с. 15-16].

Л.М. Рябцев, аналізуючи адміністративну відповідальність, називає ії інструментом забезпечення правопорядку в окремих сферах суспільного життя та зосереджує увагу на іiі функціях: виховальній (формування правосвідомості), відновлювальній (відновлення стану речей на засаді матеріальної компенсації за завдану шкоду), превентивній (профілактика правопорушень у цій сфері через усвідомлення невідворотності негативних наслідків) і функції покарання (застосування до правопорушника адміністративних стягнень на засаді принципів невідворотності й справедливості покарання) [9, с. 56].

Правовою підставою для застосування адміністративної відповідальності слугує юридичний факт скоєння адміністративного проступку, тобто наявність у діях правопорушника складу адміністративного делікту. Аналізуючи адміністративні проступки взагалі, науковці пропонують розуміти під ними протиправні, винні (навмисні або необережні) з невеликим ступенем суспільної небезпеки діяння (дії чи бездіяльність), що посягають на права й свободи громадян, права й законні інтереси юридичних осіб, власність, громадський порядок і громадську безпеку, встановлений порядок діяльності державних органів та установ. Визначити специфічні риси адміністративного правопорушення, що відрізняють його від інших порушень публічних інтересів, можна за допомогою дослідження його структури.

Традиційно в адміністративно-правовій науці елементами складу адміністративного правопорушення визнаються об'єКт, об'єктивна сторона, суб'єкт і суб'єктивна сторона. Об'єкт проступку в науковій літературі зазвичай визначають як усталене функціонування певної групи суспільних відносин, яким цей проступок заподіює шкоду або створює загрозу такого заподіяння [10, с. 4].

Якщо об'єктом правопорушення виступає публічний інтерес, то таке класичне визначення потребує деяких уточнень. У такому випадку правовідносини, що порушуються, мають бути потенційною сферою реалізації конкретного публічного інтересу; точніше кажучи, об'єктом адміністративного правопорушення $є$ не безпосередньо досліджуваний інтерес, а його об'єктивація у формі окремих суспільних відносин. Водночас захист відбивається у виді підтримки усталеного функціонування зазначених відносин шляхом заборони певних видів поведінки під загрозою покарання, завдяки чому окреслюються межі допустимої та вказуються форми неправомірної поведінки.

На нашу думку, можна впевнено стверджувати, що об'єктом адміністративного делікту можуть бути всі без винятку суспільні відносини, охоплені Особливою частиною КУпАП, як сфери реалізації публічних інтересів. Дійсно, до сфери адміністративної відповідальності входять правовідносини, метою яких є захист особи, охорона особистих і громадянських прав і свобод, охорона здоров'я громадян, санітарно-епідемічного благополуччя населення, охорона праці, захист суспільної моральності, охорона довкілля, збереження порядку встановленої державної влади, громадського порядку й безпеки, власності, законних економічних інтересів фізичних та юридичних осіб - усіх соціальних цінностей, які захищаються законом. Безпосередні об'єкти проступків визначаються конкретними статтями КУпАП, що встановлюють адміністративні санкції для охорони відповідних суспільних відносин.

Об'єктивна сторона аналізованих адміністративних проступків характеризується складною поведінкою суб'єкта правопорушення, яка може набувати форми як дії, так 
i бездіяльності. Прикладом першої може послугувати порушення публічного інтересу в збереженні приватної власності шляхом вчинення дрібного викрадення чужого майна шляхом крадіжки, шахрайства, привласнення чи розтрати (ст. 51 КУпАП), другої - порушення публічного інтересу в збереженні якості земельних ресурсів через невжиття суб'єктом господарювання необхідних заходів по боротьбі з бур'янами (ст. 52 КУПАП).

Питання суб'єкта адміністративного проступку у сфері захисту публічних інтересів потребує особливої уваги. Згідно з положеннями КУпАП таким є «особа, що його вчинила»; водночас не уточнено, фізична або юридична особа. Однак перелік ознак, закріплених нормативно (ст. 12 КУпАП - вік, після досягнення якого настає адміністративна відповідальність (16 років); ст. 20 - осудність; ст. 33 - вимога враховувати особу правопорушника в разі накладення стягнення тощо) дозволяє впевнено стверджувати, що до суб'єктів адміністративних деліктів Кодекс відносить виключно фізичних осіб. Окремо - ст. 14 - оговорюється відповідальність посадових осіб; крім того, ст. 27 КУпАП абсолютно точно визначає, що штраф є грошовим стягненням, яке накладається на громадян і посадових осіб за адміністративні правопорушення. 3 цього випливає, що адміністративну відповідальність можуть нести фізичні або посадові особи.

У зв' язку із цим актуалізується питання про відсутність юридичних осіб серед суб'єктів, на яких адміністративним законодавством накладаються стягнення за вчинення проступків, що порушують публічні інтереси. Цей момент можна вважати суттєвим недоліком вітчизняного законодавства, його невідповідності вимогам часу, адже нині саме юридичні особи є найбільш потужними гравцями в економічній сфері суспільних відносин, тому питання про наділення їх деліктоздатністю перебуває в центрі наукової уваги.

Взагалі тематику визнання юридичних осіб суб'єктами адміністративної відповідальності не можна вважати новою: вже в першому вітчизняному підручнику з адміністративного права В.Б. Авер'янов зазначав необхідність законодавчого закріплення адміністративної відповідальності підприємств, установ, організацій та об'єднань громадян, підкреслюючи, що відповідальність їхніх посадових осіб в деяких випадках не завжди вдається встановити й довести, що врешті-решт детермінує безкарність проступків i, як наслідок, зниження ефективності державного управління [2, с. 464]. Однак і досі в КУпАП, як було зазначено вище, не внесено відповідних змін.

Останній елемент структури адміністративного правопорушення - суб'єктивна сторона адміністративного проступку - характеризується психічним ставленням суб'єкта до вчиненого діяння; ії атрибутивною ознакою в юридичній літературі називають вину, яку визначають через форми умислу й необережності [11, с. 115]. Зазначимо, що в нашому випадку через широкий обсяг суспільних відносин, що входять до сфери можливого скоєння правопорушень досліджуваного типу, спостерігається наявність усіх зазначених форм вини. Можлива також і складна змішана форма вини - комплекс умислу й необережності, коли особа, завдаючи шкоди певному суспільному інтересу, необережно ставиться до можливості настання негативних наслідків, не усвідомлюючи небезпечність такої моделі поведінки.

Специфічною рисою, що виокремлює адміністративну відповідальність 3-поміж інших інструментів адміністративно-правового захисту публічних інтересів, є наявність функції покарання; якщо розглянуті раніше адміністративний контроль і судове оскарження спрямовані передусім на запобігання (припинення) правопорушень і відновлення законного стану речей, то адміністративна відповідальність передбачає також застосування адміністративних стягнень. Це робить адміністративну відпові- 
дальність завершальною формою серед інших заходів адміністративного примусу завдяки матеріалізації правової оцінки, наданої правопорушенню та особі правопорушника в процесі розгляду справи й винесення щодо неї відповідної постанови, у вигляді обтяжливих матеріальних чи моральних наслідків, що їх зазнає винний суб'єкт $[12$, с. 98].

Адміністративні стягнення як заходи адміністративної відповідальності в найбільш загальному вигляді являють собою передбачені законом засоби впливу на поведінку особи, яка вчинила адміністративне правопорушення, пов'язані з обмеженням найбільш значущих для людини прав і свобод особистого чи майнового характеру й спрямовані на досягнення соціально корисних цілей і результатів [13, с. 237], у нашому випадку - на захист і відновлення публічних інтересів.

Ст. 24 КУпАП передбачає такі види адміністративних стягнень:

1) попередження;

2) штраф;

3) штрафні бали;

4) оплатне вилучення предмета, який став знаряддям вчинення або безпосереднім об'єктом адміністративного правопорушення;

5) конфіскація: предмета, який став знаряддям вчинення або безпосереднім об'єктом адміністративного правопорушення; грошей, одержаних внаслідок вчинення адміністративного правопорушення;

6) позбавлення спеціального права, наданого громадянинові (права керування транспортними засобами, права полювання);

7) позбавлення права обіймати певні посади або займатися певною діяльністю;

8) громадські роботи;

9) виправні роботи;

10) адміністративний арешт;

11) арешт з утриманням на гауптвахті;

12) адміністративне видворення за межі України іноземців та осіб без громадянства (окремо оговорене в Кодексі, до переліку не включено).

Наведений перелік адміністративних стягнень у КУпАП не є вичерпним, про що свідчить частина 2 ст. 24 КУпАП, де йдеться про те, що законами України може бути встановлено й інші, крім зазначених у цій статті, види адміністративних стягнень.

Зазначене не означає, що в разі захисту окремого публічного інтересу має використовуватися весь спектр затверджених у Кодексі стягнень; як правило, в окремих галузях залучений певний набір санкцій, застосування яких вважається найбільш ефективним у такому випадку. Пропонуємо проілюструвати це на окремих прикладах.

Не потребує посиленої аргументації твердження про наявність публічного інтересу щодо забезпечення безпеки дорожнього руху, адже ця сфера суспільних відносин стосується всіх незалежно від віку, статі, стану здоров'я, наявності посвідчення водія або автотранспортного засобу - абсолютно всі є учасниками дорожнього руху й зацікавлені в тому, щоб участь ця відбулась без спричинення шкоди життю та здоров'ю. До того ж ситуація в цій сфері в Україні не може вважатися задовільною: щорічно в Україні трапляється понад 150 тис. дорожньо-транспортних пригод (далі - ДТП), що надає нашій країні сумно високе місце в європейському рейтингу держав за кількістю ДТП [14, с. 190].

Серед першопричин такого стану речей дослідники вказують насамперед низький рівень транспортної дисципліни учасників дорожнього руху, одним із найбільш дієвих засобів підвищення якого вважають застосування заходів адміністративної відповідальності. Цілком логічно, що в цій галузі використовується досить широкий арсенал адміністративних стягнень. До того ж для притягнення до адміністративної 
відповідальності в цій сфері настання негативних наслідків не є обов'язковою умовою: через високу суспільну значущість публічного інтересу, який захищається, покарання передбачені за сам факт порушення правил поводження на дорозі.

Найменш суворе стягнення - попередження - передбачено за порушення, досить ухильно визначене ст. 125 КУпАП як «інше порушення правил дорожнього руху, крім передбачених ст. 121-128, частинами 1 и 2 ст. 129, ст. ст. 139 і 140 КУпАП». Штрафні бали - спеціальне стягнення, передбачене КУпАП за правопорушення у сфері забезпечення безпеки дорожнього руху, - знімаються з громадян за, наприклад, порушення частини 1 ст. 122 - перевищення встановлених обмежень швидкості руху транспортних засобів більш як на 20 км за годину тощо. Штрафи застосовуються в досліджуваній сфері в надзвичайно широкому грошовому діапазоні: від трьох неоподаткованих мінімумів доходів громадян (далі - НМДГ) за порушення правил користування ременями безпеки або мотошоломом (частина 5 ст. 121) до двох тисяч чотирьохсот НМДГ за керування транспортними засобами особами в стані алкогольного, наркотичного чи іншого сп'яніння або під впливом лікарських препаратів, що знижують увагу й швидкість реакції, передачу керування транспортним засобом особі, яка перебуває в такому стані, а також за відмову особи, яка керує транспортним засобом, від проходження відповідно до встановленого порядку огляду на стан алкогольного, наркотичного чи іншого сп' яніння, якщо особа двічі протягом року вже піддавалася такому адміністративному стягненню (частина 3 ст. 130). Така санкція, як позбавлення спеціального права - права керування транспортними засобами - на строк від 3 до 6 місяців, застосовується в разі повторного протягом року вчинення порушення, передбаченого частинами 1, 2, 3 ст. 121 (керування транспортним засобом, що має несправності; керування транспортним засобом, що використовується для перевезення пасажирів і має несправності; керування транспортним засобом, що підлягає обов' язковому технічному контролю, але своєчасно його не пройшов).

Деякими статтями КУпАП передбачено альтернативні санкції: так, частина 3 ст. 123 закріплює позбавлення права керування транспортними засобами на строк від 1 до 3 років з оплатним вилученням транспортного засобу у власника або без такого або адміністративний арешт на строк від 10 до 15 діб з оплатним вилученням транспортного засобу у власника або без такого за в'їзд на залізничний переїзд у випадку, коли рух через переїзд заборонений, вчинений під час надання послуг із перевезення пасажирів або під час перевезення небезпечних вантажів. За залишення водіями транспортних засобів чи іншими учасниками дорожнього руху місця ДТП, до якої вони причетні, ст. 122-4 передбачає штраф, або громадські роботи на строк від 30 до 40 годин, або адміністративний арешт на строк від 10 до 15 діб. У ст. 122-5 запропоновано таке додаткове до штрафу стягнення, як конфіскація предмета, який став знаряддям вчинення правопорушення, в такому разі - спеціальних світлових або звукових сигнальних пристроїв.

Таким чином, перелік адміністративних стягнень, що застосовуються в галузі забезпечення безпеки дорожнього руху, можна без перебільшення вважати чималим: попередження, штраф, штрафні бали, оплатне вилучення транспортного засобу, конфіскація знаряддя вчинення правопорушення, позбавлення спеціального права, громадські роботи, адміністративний арешт - майже всі санкції, передбачені КУпАП, використано як засоби охорони громадської безпеки в галузі дорожнього руху. Водночас якщо попередження, штраф, громадські роботи мають лише виправно-виховний вплив на правопорушника, то такі види покарань, як позбавлення права керувати автотранспортом і конфіскація пристроїв, додатково виключають можливість повторного скоєння цією особою такого правопорушення. 
Слід також зазначити, що систему заходів адміністративної відповідальності в досліджуваному сегменті публічних інтересів було неодноразово піддано перегляду й корективам. Так, 7 липня 2016 р. набрав чинності Закон «Про внесення змін до Кодексу України про адміністративні правопорушення щодо посилення відповідальності за керування транспортними засобами $b$ стані алкогольного, наркотичного чи іншого сп'яніння або під впливом лікарських препаратів, що знижують увагу й швидкість реакції», яким було закріплено підвищені в порівнянні з попередньою редакцією КУпАП розміри штрафів за зазначені правопорушення [15]. Результативність цього заходу виправдала себе досить швидко: так, за даними статистики Патрульної поліції, у 2017 р. кількість ДТП, скоєних нетверезими водіями, знизилася майже вдвічі - на 42 \% у порівнянні 3 попереднім періодом; у 2018 р. таких ДТП поменшало ще на 14, 9 \% [16].

Таким чином, своєчасний перегляд переліку санкцій, встановлення нових розмірів грошових штрафів - це один із найбільш дієвих варіантів удосконалення системи заходів адміністративної відповідальності в частині ефективності. Зрозуміло, що не тільки в цьому полягає оптимізація управлінської діяльності в досліджуваній галузі; жоден, навіть найбільш досконалий нормативно-правовий акт не може позитивно вплинути на ситуацію без відповідної практики правозастосування. Однак взагалі досягнуті результати дозволяють констатувати наявність позитивних змін і сподіватися на розвиток цієї тенденції в галузі захисту безпеки дорожнього руху як публічного інтересу.

Інший приклад являє собою ситуація в галузі адміністративно-правового захисту засобами адміністративної відповідальності публічного інтересу в збереженні природних якостей довкілля. Як і у сфері безпеки дорожнього руху, підвищена цінність інтересу, що захищається, доводиться самим фактом скоєння правопорушення: за диспозиціями окремих норм для застосування санкцій досить вчинення зазначеної в законі дії (бездіяльності) безвідносно до настання негативних наслідків. Адміністративна відповідальність настає навіть за замах на правопорушення, тобто реальна шкода може й не бути заподіяна.

Одним із найбільш болючих питань української сучасності є захист лісового масиву, передусім карпатських лісів, які внесені до списку ЮНЕСКО як «букові праліси Карпат». Ця екологічна скарбниця, занесена до переліку світової спадщини, нині перебуває під загрозою зникнення через нераціональне поводження, хижацькі масові вирубки, засмічення та порушення пожежної безпеки. Тож, вважаємо, проблема збереження цього унікального лісового масиву становить неабиякий публічний інтерес - як в аспекті сучасності, так і заради прийдешніх поколінь.

Перелік адміністративних лісових правопорушень визначено ст. ст. 63-77-1 КУпАП. Щодо змісту санкцій, визначених цими статтями, слід оговорити, що тут не спостерігається такого різноманіття, як у попередньому прикладі: серед засобів адміністративного покарання, призначених за порушення правил поводження з лісовими ресурсами, виключно штрафи. Розмір штрафів варіюється залежно від виду делікту - від одного НМДГ для фізичних осіб за знищення або пошкодження лісоосушувальних канав, дренажних систем і шляхів на землях державного лісового фонду (ст. 74 КУпАП), знищення або пошкодження відмежувальних знаків у лісах (ст. 75 КУпАП), знищення корисної для лісу фауни (ст. 76) - до дев'ятисот НМДГ для посадових осіб за незаконну порубку, пошкодження та знищення лісових культур і молодняка за умови повторного вчинення порушення протягом року (ст. 65 КУпАП).

На наш погляд (і тут ми скоріше приєднуємося до думки дослідників, ніж висловлюємо авторську позицію), такі грошові суми явно свідчать про недостатню захищеність українських лісів вітчизняним законодавцем. Беручи до уваги, що лише у 2015 р. 
в Україні, за офіційними даними, незаконно було вирубано 25 тис. кубів лісу, що завдало збитків майже на 85 мільйонів гривень, а за перше півріччя 2016 р. незаконна вирубка зросла на 30 \% у порівнянні з відповідними періодами минулого року й становила по галузі 15.8 тис. кубів - майже 74 мільйонів гривень (і це лише офіційні цифри, вочевидь далекі від реальних), можна собі уявити, які прибутки мають розкрадачі лісу. За словами Г.І. Балюка, якщо за один рейс до лісу можна незаконно заробити майже 100 тис. гривень, то штраф 1,7 тисяч гривень для порушників нічого не означає [17, с. 86].

Доповнює цю думку Ю.О. Легеза, розмірковуючи про обгрунтованість визначення розміру шкоди, заподіяної внаслідок вчинення правопорушень у сфері використання природних ресурсів. За загальним правилом порядок обчислення розмірів екологічної шкоди встановлюється відповідно до таксового методу; у справах про лісові порушення розмір заподіяної шкоди обчислюється за відповідними таксами, що затверджені постановою Кабінету Міністрів України від 23 липня 2008 р. № 665 «Про затвердження такс для обчислення розміру шкоди, заподіяної лісу» тощо. Як видно, цей нормативно-правовий акт ухвалено понад 10 років тому, і навіть з урахуванням індексу інфляції розмір матеріальної шкоди, який визначається за відповідними таксами, є морально застарілим і вимагає перегляду [18, с. 192]. На нашу думку, приклад застосування заходів адміністративної відповідальності в галузі безпеки дорожнього руху переконливо доводить, що оптимізація адміністративних стягнень в частині зростання грошового розміру штрафних санкцій позитивно впливає на ефективність адміністративно-правового захисту, тому в процесі захисту публічного інтересу в збереженні лісового масиву України слід скористатися цим перевіреним шляхом.

Висновки. Взагалі, підбиваючи підсумки здійсненого аналізу, маємо зазначити існування низки проблемних аспектів у сфері застосування адміністративної відповідальності як інструменту правового захисту публічних інтересів. Стосуються вони насамперед визнання суб'єктами адміністративної відповідальності не лише фізичних, а й юридичних осіб і необхідності загального перегляду встановлених законодавством санкцій за правопорушення в досліджуваній сфері, як і їх корекції в частині розмірів штрафу для відповідності до вимог сьогодення.

Насамкінець хотілося б підкреслити ключову, визначальну роль ефективного й налагодженого механізму притягнення до адміністративної відповідальності в загальній системі правового захисту публічних інтересів. Виконуючи профілактично-превентивну, виховальну, відновлювальну й карну функції, інститут адміністративної відповідальності становить базис ефективного функціонування всього адміністративно-правового механізму забезпечення реалізації публічних інтересів.

\section{Список використаних джерел:}

1. Алексеев С.С. Право: азбука - теория - философия : опыт комплексного исследования. Москва : Статут, 1999. 712 с.

2. Адміністративне право України: академічний курс : підручник : у 2-х т. / за ред. В.Б. Авер'янова. Київ : ТОВ «Видавництво «Юридична думка», 2007. Т. 1 : Загальна частина. 592 с.

3. Сердюк I.А. Методологічний аналіз сучасних інтерпретацій поняття «юридична відповідальність». Право і суспільство. 2010. № 5. С. 45-50.

4. Битяк Ю.П. Административное право Украины : учебное пособие. Харьков : Одиссей, 1999. 224 с.

5. Адміністративне право України. Академічний курс : підручник для студентів юридичних спеціальностей вищих навчальних закладів : у 2 т. / за ред. В.Б. Авер'янова. Київ : Юридична думка, 2004. Т. 1 : Загальна частина. 584 с. 
6. Адміністративна відповідальність в Україні : навчальний посібник / за заг. ред. А.Т. Комзюка. 2-е вид., перероб. і доп. Харків : Ун-т внутр. справ, 2000. 99 с.

7. Колпаков В.К. Адміністративне право України : підручник / В.К. Колпаков, О.В. Кузьменко. Київ : Юрінком Інтер, 2003. 544 с.

8. Мілімко Л.В. Адміністративна відповідальність за правопорушення у сфері земельних відносин : автореф. дис. ... канд. юрид. наук : 12.00.07. Ірпінь, 2009. 24 с.

9. Рябцев Л.М. Об административной ответственности и административных взысканиях за совершение экологических правонарушений. Приоритетные направления развития экологического, земельного и аграрного права: материалы Республиканского круглого стола, г. Минск, 30 марта 2017 г. Минск : Издат. центр БГУ, 2017. С. 55-58.

10. Липатов Э.Г. Административная ответственность : учебно-практическое пособие / под ред. С.Е. Чаннова. Москва : Волтерс Клувер, 2010. 383 с.

11. Колпаков В.К. Адміністративна відповідальність (адміністративно-деліктне право) : навч. посіб. К. : Юрінком Інтер, 2008. 256 с.

12. Козюренко Р.С. Заходи адміністративної відповідальності за вчинені правопорушення: поняття та класифікація. Вісник Національного університету «Львівська політехніка». Юридичні науки. 2016. № 845. С. 94-98.

13. Романюк В.В. Сутність та правова природа заходів адміністративної відповідальності. Підприємницывво, господарство і право. 2019. № 3. С. 236-240.

14. Горкава В.В. Адміністративна відповідальність у сфері дорожнього руху : теоретико-правові аспекти. Вісник Національного університету «Львівська політехніка». Серія: юридичні науки : збірник наукових праць. 2017. № 865. С. 190-197.

15. Про внесення змін до Кодексу України про адміністративні правопорушення щуодо посилення відповідальності за керування транспортними засобами у стані алкогольного, наркотичного чи іншого сп'яніння або під впливом лікарських препаратів, що знижують увагу та швидкість реакції : Закон України від 07 липня 2016 р. № 1446-VIII / Верховна Рада Украйни. URL: https:/ / zakon.rada.gov.ua/laws/show/1446-19.

16. Статистика ДТП в Україні. Патрульна поліція : офіційний сайт. URL: http:/ / patrol.police.gov.ua/statystyka/.

17. Балюк Г.І. Концептуально-правові «реформи» у сфері екології в Україні та сучасні виклики. Сочіолого-правові, політичні, економічні та екологічні складові забезпечення сприятливого життєвого простору людини: теоретико-методологічні та прикладні проблеми розвитку екологічного права і правової охорони довкілля : матеріали Міжнар. наук.-практ. конференції. Київ, 2016. С. 80-87.

18. Легеза Ю.О. Адміністративно-правові засади публічного управління у сфері використання природних ресурсів : дис. ... Д-ра юрид. наук : 12.00.07. Запоріжжя, 2018. 512 c. 
УДК 341.231

DOI https:// doi.org/10.32850/LB2414-4207.2020.14.06

\title{
АНАЛІЗ ПРАВОВОГО МЕХАНІЗМУ ЗАБОРОНИ КАТУВАНЬ В УКРАЇНI
}

\author{
Кузьменко Юлія Василівна, \\ доктор педагогічних наук, доцент, \\ професор кафедри адміністративного \\ права та адміністративного процесу \\ (Херсонський факультет Одеського \\ державного університету \\ внутрішніх справ, \\ м. Херсон, Україна)
}

У статті здійснено аналіз законодавчого простору України у руслі створення дієвої логістики протидії злочинам катування, висвітлено правову сутність цієї категорії. Висловлено переконання, що заборона катувань чи нелюдського або такого, яка принижує гідність, поводження чи покарання виступає одним із основних прав і одночасно є гарантією таких невід'ємних прав людини, як право на життя, здоров'я, свободу й особисту недоторканність, право на повагу честі та гідності кожного індивіда. Окреслено ряд нормативно-правових документів, що становлять урегульовану систему захисту від катувань державного рівня. Представлено правовий механізм заборони катування: людина має право на подання скарги про здійснення над нею катувань, ведеться реєстрація цих звернень, проводиться робота із працівниками правоохоронних органів щодо запобігання упередженого та негативного ставлення до жертв, ведеться облік статистичних даних таких злочинів, проводяться слідчі дії щодо розкриття таких правопорушень, жертва має право звернутися і до Європейського суду з прав людини. У перспективі вважаємо, що для більшої продуктивності необхідно ст. 127 Кримінального кодексу України зробити ідентичною до ст. 1 Конвенції ООН проти катувань, безпосередньо окресливши ознаки катувань як їхнє вчинення посадовими особами чи іншими особами, котрі виступають як офіційні, чи з їх підбурювання, чи з їхнього відома, чи за їхньої мовчазної згоди. Заборона катувань повинна бути абсолютною категорією національного законодавства і не може мати будь-яких винятків із загального правила чи то під час тримання під вартою чи відбування покарання, або у процесі затримання та проведення слідчих дій співробітниками поліції, Служби безпеки України, Державного бюро розслідування, державної виконавчої служби. Лише у такому випадку Україна відповідатиме статусу демократичної та правової держави світу, що спрямовує свою політику на дотримання основоположних прав і свобод людини та виконання міжнародних вимог до протидії правопорушенням.

Ключові слова: катування, правовий механізм, заборона катування, право на життя, здоров'я, свободу й особисту недоторканність, жертва, захист прав людини щодо злочинів катування. 


\title{
ANALYSIS OF THE LEGAL MECHANISM FOR THE PROHIBITION OF TORTURE IN UKRAINE
}

\author{
Kuzmenko Yuliia Vasylivna, \\ PhD, Assistant Professor, \\ Professor at the Department of \\ Administrative Law \\ and Administrative Procedure \\ (Kherson Faculty of the Odessa State \\ University of Internal Affairs, \\ Kherson, Ukraine)
}

This article analyzes the legislative space of Ukraine in line with the creation of effective logistics to combat the crimes of torture, highlights the legal essence of this category. It is believed that the prohibition of torture, inhuman or degrading treatment or punishment is a fundamental right and at the same time a guarantee of such inalienable human rights as the right to life, health, liberty and security of person, the right to respect for the honor and dignity of each individual.

A number of legal documents that make up a regulated system of protection against statelevel torture are outlined. There is presented the legal mechanism of prohibition of torture: a person has the right to file a complaint about torture, registration of these appeals is carried out, work with law enforcement officers is carried out to prevent prejudice and negative attitude towards victims, statistics of such crimes are kept, investigative actions are carried out. Such offenses, the victim has the right to apply to the European Court of Human Rights. In the future, we believe that for greater productivity requires Art. 127 of the Criminal code of Ukraine to make identical to Art. 1 of the UN Convention against Torture, directly outlining the signs of torture, such as their commission by officials or other persons acting as officials, or with their incitement, or with their knowledge, or with their tacit consent.

The prohibition of torture must be an absolute category of national law and may not have any exceptions to the general rule, whether during detention or imprisonment, or in the process of detention and investigation by police, the Security Service of Ukraine, the State Bureau of investigation, state executive service. Only in this case Ukraine will meet the status of a democratic and legal state of the world, which directs its policy within the framework of respect for fundamental human rights and freedoms and compliance with international requirements to combat crime.

Key words: torture, legal mechanism, prohibition of torture, right to life, health, liberty and security of person, victim, protection of human rights in relation to the crimes of torture.

Постановка проблеми та іiі актуальність. Україна як демократична та правова держава спрямовує свою політику на дотримання основоположних прав і свобод людини та виконання міжнародних вимог до протидії правопорушенням. «Сучасні реалії спонукають нас до активного обговорення та дій щодо протидії злочинам у різних сферах життя» [7, с. 12]. Зокрема, заборона катувань чи нелюдського або такого, що принижує гідність, поводження чи покарання виступає одним із основних прав i одночасно є гарантією таких невід'ємних прав людини, як право на життя, здоров'я, свободу й особисту недоторканність, право на повагу честі та гідності кожного індивіда. Саме тому таке явище, як катування $є$ протиправним у нашій країні. Проте багато чинників сприяють проявам такого виду насильства, особливо вплив збройного конфлікту на Сході України. Тому означене нами питання є актуальною проблемою дослідження сучасної теорії та практики юридичної науки. 
Аналіз останніх досліджень і публікацій. Цій проблемі присвячено широке коло наукових публікацій як вітчизняних, так і закордонних дослідників. Зокрема, Г. Борзенков, О. Орлова, Є. Захаров та ін. висвітлювали поняття катування, нелюдського та такого поводження чи покарання, що принижує людську гідність. А. Замула, В. Лутковська, П. Пушкар, А. Червяцова, С. Шевчук розглядали застосування практики Свропейського суду з прав людини у сфері захисту прав людини щодо злочинів катування.

Одним із важливих факторів захисту від катувань є урегульована система національного рівня щодо дотримання та захисту прав і свобод людини, тому мета статті проаналізувати правовий механізм заборони катувань в Україні.

Виклад основного матеріалу. Заборона катування закріплена у ст. 3 міжнародної Конвенції «Проти катувань та інших жорстоких, нелюдських або таких, що принижують гідність, видів поводження і покарання», є абсолютною за своєю сутністю і не може підлягати ніяким обмеженням чи виняткам.

Аналіз законодавчого простору України у руслі створення дієвих механізмів протидії злочинам катування показав, що значна кількість нормативно-правових актів містять складові частини захисту прав людини від жорстокого поводження та катування.

У ст. 28 Конституції України визначено, що кожен має право на повагу до його гідності; ніхто не може бути підданий катуванню, жорстокому, нелюдському або такому, що принижує його гідність, поводженню чи покаранню; жодна людина без ії вільної згоди не може бути піддана медичним, науковим чи іншим дослідам [2].

У ст. 289 Цивільного кодексу України зазначено, що фізична особа має право на особисту недоторканність. Фізична особа не може бути піддана катуванню, жорстокому, нелюдському або такому, що принижує ії гідність, поводженню чи покаранню. Фізичне покарання батьками (усиновлювачами), опікунами, піклувальниками, вихователями малолітніх, неповнолітніх дітей і підопічних не допускається. У разі жорстокої, аморальної поведінки фізичної особи щодо іншої особи, яка перебуває в безпорадному стані, застосовуються заходи, встановлені цим Кодексом та іншим законом [10].

Кримінальний процесуальний кодекс України у ст. 11 передбачає такі положення: під час кримінального провадження повинна бути забезпечена повага до людської гідності, прав і свобод кожної особи. Забороняється під час кримінального провадження піддавати особу катуванню, жорстокому, нелюдському або такому, що принижує іï гідність, поводженню чи покаранню, вдаватися до погроз застосування такого поводження, утримувати особу за принизливих умов, примушувати до дій, які принижують ії гідність. Кожен має право захищати усіма засобами, що не заборонені законом, свою людську гідність, права, свободи та інтереси, порушені під час здійснення кримінального провадження [4].

Ст. 87 цього Кодексу говорить про недопустимість доказів, отриманих внаслідок істотного порушення прав і свобод людини. Так, недопустимими є докази, отримані внаслідок істотного порушення прав і свобод людини, гарантованих Конституцією та законами України, міжнародними договорами, згода на обов' язковість яких надана Верховною Радою України, а також будь-які інші докази, здобуті завдяки інформації, отриманій внаслідок істотного порушення прав і свобод людини. Суд зобов'язаний визнати істотними порушеннями прав людини й основоположних свобод, зокрема отримання доказів внаслідок катування, жорстокого, нелюдського або такого, що принижує гідність особи, поводження або погрози застосування такого поводження. Зазначені докази повинні визнаватися судом недопустимими під час будь-якого судо- 
вого розгляду, крім розгляду, якщо вирішується питання про відповідальність за вчинення зазначеного істотного порушення прав і свобод людини, внаслідок якого такі відомості були отримані [4].

Особливо слід відзначити ст. 206 КПК України «Загальні обов'язки судді щодо захисту прав людини». Згідно з нею кожен слідчий суддя суду, в межах територіальної юрисдикції якого перебуває особа, котра тримається під вартою, має право постановити ухвалу, якою зобов' язати будь-який орган державної влади чи службову особу забезпечити додержання прав такої особи.

Якщо під час судового засідання особа заявляє про застосування до неї насильства під час затримання або тримання в уповноваженому органі державної влади, державній установі (органі державної влади, державній установі, яким законом надано право здійснювати тримання під вартою осіб), слідчий суддя зобов' язаний зафіксувати таку заяву або прийняти від особи письмову заяву та:

- забезпечити невідкладне проведення судово-медичного обстеження особи;

- доручити відповідному органу досудового розслідування провести дослідження фактів, викладених у заяві особи;

- вжити необхідних заходів для забезпечення безпеки особи згідно із законодавством [4].

Безпосередньо ст. 127 Кримінального кодексу України передбачає відповідальність за катування, тобто умисне заподіяння сильного фізичного болю або фізичного чи морального страждання шляхом нанесення побоїв, мучення або інших насильницьких дій із метою примусити потерпілого чи іншу особу вчинити дії, що суперечать їхній волі, у т. ч. отримати від нього або іншої особи відомості чи визнання, або з метою покарати його чи іншу особу за дії, скоєні ним або іншою особою чи у скоєнні яких він або інша особа підозрюється, а також із метою залякування чи дискримінації його або інших осіб [3]. Отже, «основним безпосереднім об'єктом катування є здоров'я людини, як обов'язковий додатковий об'єкт виступають честь, гідність і воля особи» [5, с. 202].

Категорія «мучення» вбачає дії, що заподіяли потерпілому страждання через тривале позбавлення води, їжі, тепла, поміщення його у шкідливі для здоров'я умови та інші подібні дії.

Інші насильницькі дії можуть бути виражені у мордуванні, чи діях, пов'язаних із тривалим спричиненням болю (кусанням, щипанням, шмаганням, нанесенням численних, проте невеликих ушкоджень різними предметами, застосуванням термічних чи звукових факторів та ін.), посяганні на статеву недоторканість, заподіянні тілесних ушкоджень, заточенні, зв' язуванні тощо.

Заподіяння потерпілому тілесних ушкоджень умисної середньої тяжкості є обставинами, що обтяжують кримінальну відповідальність за цей злочин, умисне тяжке тілесне ушкодження потребує додаткової кваліфікації за ч. 2 ст. 122 ККУ або ч. 1 чи 2 ст. $121 \mathrm{KКУ.}$

Якщо катування було поєднане з незаконним позбавленням волі, згвалтуванням, насильницьким задоволенням статевої пристрасті неприродним способом, то вчинене належить кваліфікувати за сукупністю злочинів, передбачених ст. 127 та відповідно до ст. 146, 152 чи 153 ККУ.

Обставинами, що обтяжують кримінальну відповідальність за катування, є: вчинення таких діянь повторно або за попередньою змовою групою осіб, або 3 мотивів расової, національної чи релігійної нетерпимості (ч. 2 ст. 127 ККУ); доведення до самогубства способом жорстокого поводження або до замаху на самогубство (ст. 120 ККУ). Відзначимо, що найпоширенішими ситуаціями вчинення катування є: «а) коли під 
час вчинення катування у злочинця виникнув прямий умисел на позбавлення життя; б) вчинення катування супроводжувалося заподіянням потерпілому фізичного чи (або) морального страждання, внаслідок якого була заподіяна смерть через необережність; в) вбивство з метою приховати факт вчинення катування потерпілого» [9, с. 177].

Одна із функцій правоохоронних органів - позбавлення волі при затриманні чи арешті. «У кримінальному провадженні обмеження прав і свобод людини є необхідною умовою для розкриття злочину, викриття винних у вчиненні правопорушень. Також обмеження прав і свобод є необхідною процедурою щодо реалізації законів, щоб лише ті особи, котрі вчинили злочини, були притягнутими до відповідальності. Обмеження прав і свобод людини відповідно до закону допустимо тільки у випадках, коли це необхідно для захисту основ конституційного ладу, державного устрою, здоров'я, прав і законних інтересів інших осіб, забезпечення безпеки держави» [6, с. 83]. Саме тому необхідне досягнення найнижчого рівня прояву жорстокості. Як відзначає О. Орлова: «Розглядаючи питання щодо порушення ст. 3 Конвенції, ССПЛ спирається на доктрину «мінімального рівня жорстокості». Доктрина «мінімального рівня жорстокості» застосовується при відокремленні катувань від нелюдського або такого, що принижує гідність, поводження чи покарання» [8, с. 63].

Національне законодавство України спрямоване на недопущення катування у ході проведення досудового розслідування. При розслідуванні кримінальних та адміністративних правопорушень органи Національної поліції, Служби безпеки України, Державного бюро розслідувань повинні дотримуватися правил допустимості та належності доказів.

Дії службової особи, яка при перевищенні влади або службових повноважень чи примушуванні давати показання застосувала катування - це незаконне застосування фізичного примусу правоохоронними органами та незаконні методи ведення слідства. Вони повинні кваліфікуватися за сукупністю злочинів: за відповідною частиною ст. 127 ККУ, ч. 2 ст. 365 та ч. 3 ст. 365 ККУ або за ч. 2 ст. 373 ККУ. Із суб'єктивної сторони злочин характеризується умисною формою вини та наявністю спеціальної мети - примусити потерпілого чи іншу особу вчинити дії, що суперечать іï волі, у т. ч. отримати від потерпілого або іншої особи відомості чи визнання, покарати його чи іншу особу за дії, скоєні ним або іншою особою чи у скоєнні яких він або інша особа підозрюються, або залякування чи дискримінація його або інших осіб.

Під час судового розгляду суд зобов' язаний визнати істотними порушеннями прав людини й основоположних свобод, зокрема, й такі діяння, як отримання доказів внаслідок катування, жорстокого, нелюдського або такого, що принижує гідність особи, поводження або погрози застосування такого поводження.

На жаль, сьогодні часті прояви катування в Україні спостерігаються у випадках невідповідних умов тримання під вартою та відбування покарання; у процесі затримання та проведення слідчих дій співробітниками поліції, Служби безпеки України, Державного бюро розслідування, державної виконавчої служби. Тому, на наш погляд, для більшої продуктивності правового механізму протидії катуванню в Україні необхідно у ККУ ст. 127 зробити ідентичною до ст. 1 Конвенції ООН проти катувань, безпосередньо окресливши ознаки катувань, «коли такий біль або страждання заподіюються державними посадовими особами чи іншими особами, які виступають як офіційні, чи з їх підбурювання, чи з їх відома, чи за їх мовчазної згоди» [1].

Висновки. Отже, заборона катувань повинна бути абсолютною категорією національного законодавства та не може мати будь-яких винятків із загального правила. Аналіз нормативно-правового-поля щодо дотримання та захисту прав, гідності та свобод людини дає підстави стверджувати, що в Україні створено правовий механізм 
заборони катування. Створено механізм правового захисту державного рівня: людина має право на подання скарги про здійснення над нею катувань, ведеться реєстрація цих звернень, проводиться робота із працівниками правоохоронних органів щодо запобігання упередженого та негативного ставлення до жертв, ведеться облік статистичних даних таких злочинів, проводяться слідчі дії щодо розкриття таких справ, жертва має право звернутися і до Свропейського суду з прав людини.

\section{Список використаних джерел:}

1. Конвенція проти катувань та інших жорстоких, нелюдських або таких, що принижують гідність, видів поводження і покарання від 26 січня 1987 р. № 3484-XI (3484-11). URL: https://zakon.rada.gov.ua/laws/show/995_085\#Text (дата звернення: 07.06.2020).

2. Конституція України від 28 червня 1996 р. № 254к/96-BP. URL: https://zakon.rada.gov.ua/laws/show/254\%D0\%BA/96-\%D0\%B2\%D1\%80\#n4250 (дата звернення: 07.06.2020).

3. Кримінальний кодекс України від 05 квітня 2001 р. № 2341-III. URL: https:/ / zakon.rada.gov.ua/laws/show/2341-14\#n816 (дата звернення: 15.08.2020).

4. Кримінальний процесуальний кодекс України від 13 квітня 2012 р. № 4651-VI. URL: https:/ / zakon.rada.gov.ua/laws/show/4651-17 (дата звернення: 14.08.2020).

5. Кричун Ю. Проблема відмежування катування від деяких суміжних складів злочинів. Підприємництво, господарство і право. 2017. Вип. 5. С. 201-204.

6. Кузьменко Ю.В. Дотримання Конституційних принципів в оперативно-розшуковій діяльності із забезпечення прав та свобод людини. Modern scientific and technical methods of management information flow and their influence on the development of society. Abstracts of V International Scientific and Practical Conference. SH SCW "NEW ROUTE" (24-25 February 2020) Frankfurt am Main, Germany. 2020. P. 82-84. URL: http:/ / isg-conf.com.

7. Кузьменко Ю.В. Правове поле у сфері протидії рейдерству. Науковий вісник Херсонського державного університету. Серія: Юридичні науки. Вип. 4. Т. 2. С. 12-16.

8. Орлова О.О. Катування, нелюдське та таке поводження чи покарання, що принижує людську гідність: розмежування понять. Науковий вісник ДДУВС. 2017. № 3. С. 62-68.

9. Скреля Л.І., Заріцький М.Д. Особливості кваліфікації злочинів, які полягають у катуванні. URL: file:///C:/Users/\%D0\%AE\%D0\%BB\%D0\%B8\%D1\%8F/Downloads/ nvlkau_2017_5_23.pdf (дата звернення: 09.08.2020).

10. Цивільний кодекс України від 16 січня 2003 р. № 435-IV. URL: https:/ / zakon.rada.gov.ua/laws/show/435-15 (дата звернення: 09.07.2020). 
УДК 347.73

DOI https:// doi.org/10.32850/LB2414-4207.2020.14.07

\title{
ФІНАНСОВО-ПРАВОВА ПРИРОДА ГРОШЕЙ
}

\author{
Радченко Олег Миколайович, \\ кандидат юридичних наук, \\ керівник апарату \\ (Київський апеляційний суд, \\ м. Київ, Україна)
}

У статті автор досліджує еволюцію грошей, розглядає їхню економічну та фінансово-правову природу. Гроші як об'єкт фінансово-правового регулювання можуть бути визначені як особливі знаки, чиє найменування закріплене в нормативно-правових актах, відповідно до яких таким знакам надається платіжна сила, виражена в кількості грошових одиниць, а також визначається порядок емісії та обігу з тим, щоб вони служили законним платіжним засобом на всій території держави.

Класифікація грошей може бути проведена за різними підставами. Залежно від матеріального вираження гроші поділяють на: 1) готівкові - грошові знаки, що існують у реальному світі, виражені в матеріальній формі банкнот або металевої монети; 2) безготівкові, які є записами на рахунках у фінансових установах, з чого випливає, що зовні вони матеріально не виражені.

Залежно від органу влади, що здійснює емісію, виділяють: 1) казначейські грошові знаки, які випускаються казначейством; 2) грошові знаки, що випускаються емісійним банком.

Залежно від національної належності гроші поділяються на: 1) національну валюту грошові знаки держави, випуск яких визнаний законним платіжним засобом на всій ії території; 2) іноземну валюту - гроші, що випускаються іноземною державою.

Залежно від конвертованості, тобто здатності валюти обмінюватися на іноземну валюту виділяють: 1) неконвертовану, під якою розуміється валюта, що не підлягає обміну; 2) частково (обмежено) конвертовану, котра існує у країнах, де встановлена система валютних обмежень (наприклад, заборонено ввезення і вивезення валюти за межі країни, обмежена можливість володіння, користування і розпорядження коштами в іноземній валюті тощо). До частково конвертованої валюти належить і українська гривня; 3) вільно конвертовану, обмін якої на інші валюти відбувається без обмежень. Така валюта вільно обертається на світовому валютному ринку.

Під грошовими сурогатами необхідно розуміти замінник грошей, що використовується як засіб платежу. Грошовий сурогат - це будь-які документи у вигляді грошових знаків, що відрізняються від грошової одиниці України, випущені в обіг не Національним банком України. Поява грошових сурогатів зазвичай не є результатом вільної конкуренції. Якщо гроші не виконують хоча б одну з цих функцій, то швидше за все це грошовий сурогат. Головною особливістю грошових сурогатів $є$ їхня обмежена ліквідність, що означає, що не будь-який платіж може бути здійснений із їх допомогою. Вони можуть використовуватися виключно для розрахунків між приватними особами, якщо між ними існує така домовленість.

Ключові слова: грошовий обіг, грошова система, грошові фонди, іноземна валюта, національна валюта, готівкові розрахунки, безготівкові розрахунки, емісія, грошові правовідносини. 


\title{
FINANCIAL AND LEGAL NATURE OF MONEY
}

\author{
Radchenko Oleh Mykolaiovych, \\ Candidate of Juridical Sciences, \\ Head of Staff of the Court \\ (Kyiv Court of Appeal, \\ Kyiv, Ukraine)
}

The author considers studies the evolution of money, considers their economic and financial-legal nature. Money as an object of financial and legal regulation can be defined as special signs the name of which is enshrined in regulations according to which such signs are given payment force expressed in monetary units and the order of issue and circulation is determined so that that they serve as legal tender throughout the territory of the state.

The classification of money can be done on various grounds. Depending on the financial expression, money is divided into: 1) cash - banknotes which are available in the real world and expressed in the material form of banknotes or metal coins; 2) non-cash money, which are accounting entries in financial institutions; it means that they do not have external financial manifestation.

Depending on the issuing authority, there are: 1) treasury monetary notes, i. e. money issued by the treasury; 2) monetary notes issued by the central bank.

Depending on the national affiliation, money is divided into: 1) national currency banknotes of the state the issue of which is recognized as legal tender throughout its territory; 2) foreign currency - m money issued by a foreign state.

Depending on the convertibility, i. e. the ability of the currency to be exchanged for foreign currency; there are: 1) non-convertible currency, which means the currency that is not subject to exchange; 2) partially (limited) convertible currency - it exists in countries which have a system of currency restrictions (for example, prohibition on the import and export of currency outside the country, limited ability to own, use and manage funds in foreign currency, etc.). The Ukrainian hryvnia also belongs to the partially convertible currency; 3) freely convertible currency, which is exchanged for other currencies without any restrictions. Such currency freely circulates in the world currency market.

Quasi-money should be understood as a substitute for money used as a means of payment Quasi-money is any documents in the form of banknotes other than the Ukrainian currency of Ukraine, which are not issued by the National Bank of Ukraine. The emergence of quasimoney is not usually the result of free competition. If money does not perform at least one of these functions, it is most likely to be quasi-money. The key feature of quasi-money is its limited liquidity, which means that not every payment can be made with their help. It can be used only for settlements between individuals, and only if there is such an agreement between them.

Key words: money circulation, monetary system, monetary funds, foreign currency, national currency, cash settlements, non-cash settlements, issue, monetary legal relations.

Вступ. Починаючи розгляд проблем фінансово-правового регулювання грошей в Україні, відзначимо, що їхнє дослідження в науці фінансового права довго недооцінювалося, оскільки гроші сприймалися науковцями-правознавцями як категорія, запозичена з економічної науки, видавалися чимось самим собою зрозумілим, вже вивченим, даним у готовому вигляді.

Постановка завдання. Дослідити гроші як об'єкт фінансово-правового регулювання.

Результати. Правові питання регулювання грошового обігу аналізувалися у працях Л.К. Воронової, Є.О. Алісова, О.П. Орлюк, О.А. Костюченко, Д.О. Гетьманцева, 
I.Б. Заверухи, В.К. Шкарупи, М.П. Кучерявенка, О.О. Качана, В.В. Козюка, Н.І. Костіна, Т.А. Латковської, А.О. Монаєнка, М.І. Савлука, А.О. Селіванова та ін.

Важливу роль у недоццінці ролі грошей у функціонуванні господарського механізму зіграла й ідеологія радянської держави. Так, на думку Й.В. Сталіна, гроші були тим інструментом буржуазної економіки, який взяла у свої руки Радянська влада і пристосувала до інтересів соціалізму [9, с. 462]. Озброївшись таким підходом, наука фінансового права скинула інститут грошового обігу на останні сторінки підручників із фінансового права, виправдовуючи тим самим ідеологічні постулати вождів радянської держави. На жаль, необхідно визнати, що і на сучасному етапі розвитку науки фінансового права зберігається недооцінка грошей і грошового обігу.

Досі існує уявлення про те, що фінансове право займається виключно суспільними відносинами, які виникають із приводу й у зв'язку із грошима, але не вивчає «фізичний субстрат», тобто самі гроші. Тим часом, як показує практика, жодне більш-менш серйозне дослідження правового регулювання грошового обігу не обходиться без розгляду поняття і сутності грошей. Важливо відзначити, що фінансово-правова наука не просто досліджує гроші, спираючись на запозичені нею положення економічної науки, вона має свій власний оригінальний підхід до їх вивчення. Відрізняється це розуміння також і від поглядів інших галузей правової науки.

Переходячи до розгляду питання по суті, відзначимо, що в науці фінансового права склалася традищія, за якою поняття грошей розглядається у двох аспектах: економічному та правовому. Цей підхід видається абсолютно виправданим, оскільки дозволяє найбільш повно охопити такий багатогранний феномен, як гроші. Як було справедливо вказано Ю.А. Ровинським, наука фінансового права не може у своєму дослідженні відволіктися від економічного змісту регульованих фінансовим правом суспільних відносин, але наука фінансового права не повинна перетворюватися в економіко-правову і розчиняти тим самим право в економіці [8, с. 105]. У зв' язку з цим нами поставлено завдання при розгляді природи і суті грошей змістити акцент з економічного на власне правовий аспект.

Економічне розуміння грошей зазвичай розкривається через розгляд функцій, які виконують гроші у процесі товарного обігу. Можна виділити такі п'ять функцій, як:

1) функція засобу обігу - в цій ролі гроші використовуються для обслуговування процесу товарного обміну, тобто виступають як посередник у процесі обігу товарів (товар - гроші - товар). Таким чином, вони усувають просторові та тимчасові обмеження натурального обміну (дозволяють купувати і продавати товар у потрібній кількості у зручний час у віддалених один від одного місцевостях);

2) функція міри вартості - гроші використовуються для вимірювання вартості різних товарів. У свою чергу, вартістю, вираженою у грошах, $є$ ціна. Встановлюючи ціни, люди встановлюють співвідношення вартостей різних товарів;

3) функція засобу накопичення - ця функція дозволяє зберігати частину доходів з метою їх використання в майбутньому. Володіючи високою ліквідністю, гроші у будь-який момент можуть бути використані як платіжний засіб (на відміну від інших засобів накопичення (коштовностей, нерухомості, цінних паперів тощо, які лише після продажу за гроші стають засобами обігу);

4) функція засобу платежу - в цій функції гроші використовуються не для придбання товарів, а для здійснення платежів, що не припускають отримання зустрічного надання, наприклад, для сплати податків;

5) функція світових грошей, яка виконується грошима в обігу між державами.

Таким чином, під грошима в економічному сенсі слід розуміти певний товар, що $є$ універсальним вимірником вартості інших товарів і виконує функції засобу обігу, накопичення та платежу. 
Тут необхідно зазначити, що гроші не є застиглою категорією - вони еволюціонували з розвитком суспільства, рівня його продуктивних сил і прискоренням процесу товарообміну. Їхня еволюція полягає в постійній і послідовній зміні видів і форм. 3 розвитком рівня суспільного виробництва гроші, які більш не відповідали потребам часу, поступово зникали з обігу і замінювалися більш досконалими.

Історично першим видом грошей стали речові або товарні. Цей вид характерний для ранніх етапів розвитку суспільного виробництва. Такими грошима, як випливає з їхньої назви, служили реальні товари. Можна виділити три основні форми товарних грошей:

1) анімалістичні товарні гроші (від лат. animal - тварина) - худоба, хутро, черепашки і т. Д.;

2) гілоістичні (від лат. hyle - речовина) - камені, метали, сіль тощо;

3) вегетабілістичні (від лат. vegetabilis - рослинні) - зерно, рослини та плоди дерев.

Такі гроші, по суті, не створювалися людиною. У процесі товарообмінних операцій люди визначали найбільш цінні та корисні для того чи іншого регіону товари, які і служили грошима.

Далі, з розвитком продуктивних сил, приблизно у VII-IV ст. до н. е. з'являється такий вид грошей, як металеві. Вони так само, як і товарні, належать до повноцінних грошей, оскільки їхня вартість визначалася вартістю матеріалу, який використовувався для їхнього виробництва. Внутрішня вартість металевих грошей визначалася вартістю валютного металу, котрим зазвичай були золото, срібло або мідь. Більшою мірою платіжна сила таких грошей також забезпечувалася цінністю валютного металу.

Спочатку металеві гроші оберталися у формі злитків, однак така форма виявилася не дуже зручною. Так, у ході товарообмінних операцій виникали проблеми з визначенням кількості та якості, тобто чистоти металу у зливку. Крім того, злитки часто доводилося ділити на дробові частини, внаслідок чого губився дорогоцінний метал. Все це призвело до того, що держава закріпила єдину форму зливків - монету. Спочатку монети мали звичну круглу форму - вони мали вигляд розплющених плашок, на яких проставляється княжа печатка, що служила гарантом повноцінності цих грошей. Із розвитком виробничих технологій монетам стали надавати більш округлу форму.

Тим часом металеві гроші, незважаючи на всі їхні переваги, мали і низку недоліків. Так, металеві монети, перебуваючи в постійному обігу, схильні до такого негативного процесу, як стирання, що вело до втрати їхньої первісної вартості. Виходило, що потерті монети настільки ж справно виконували функцію засобу обігу, як і нові, і їхня номінальна вартість була однаковою. Тому державі доводилося вилучати з обігу зношені монети та карбувати нові. Крім того, саме карбування металевих монет було справою досить витратною. Держава часом свідомо йшла на псування монет, що виражалося у зниженні відсотка дорогоцінного металу, який містився в них, а також у заміні дорогих грошей дешевшими, наприклад, золотих монет - срібними, а срібних - мідними. Така діяльність приносила непоганий дохід у державну казну. Особливо цю практику вели французькі королі - Філіп IV за таку діяльність був прозваний «фальшивомонетником».

Прагнучи знизити витрати грошового виробництва, держава вводить в обіг паперові гроші. На відміну від металевих, вони не мали внутрішньої вартості та наділялися примусовим курсом.

Першим видом паперових грошей стали казначейські білети. Вони випускалися державою в особі Міністерства фінансів або казначейства і не підлягали обміну на золото. Внаслідок того, що такі грошові знаки були нічим не забезпечені, їхня 
платіжна сила, тобто обов' язковість їх прийому як засобу платежу, забезпечувалася виключно державним владним велінням. Ще одним наслідком незабезпеченості казначейських білетів стала їхня безконтрольна емісія. Постійні війни вимагали від держав дедалі більших і більших витрат, тому вони вмикали друкарський верстат щоразу, коли в цьому була необхідність, не замислюючись про наслідки такої грошової емісії. Внаслідок цього гроші дедалі сильніше знецінювалися, довіра до них падала, а інфляція зростала.

Недосконалість таких грошей призвела до появи банкнот. Спочатку банкноти були векселями, що містили зобов' язання банку виплатити пред'явнику зазначену в ньому суму золотом. Такі банкноти випускалися комерційними банками та забезпечувалися їхніми золотими запасами, у зв'язку з чим вони мали більшу цінність і надійність, ніж векселі, видані іншими приватними особами. Такі банкноти ще не були грошима в повному сенсі цього слова - вони поки не визнавалися законним платіжним засобом і застосовувалися лише у сфері приватних розрахунків. Поступово банкноти стали використовуватися як засіб готівкового платежу, отримавши властивість загального обігу. Згодом держава визнала їх законним платіжним засобом, а виняткове право на емісію банкнот було закріплене за державним емісійним банком.

Залежно від забезпечення банкнот можна виділити:

1) банкноти з повним покриттям, що підлягали обміну на золото в необмеженій кількості, обмінний курс відповідав ринковим цінам;

2) банкнотиз частковим покриттям - золотий запас забезпечував лише частину випущених банкнот, а їх розмінний курс був нижчим за номінал банкнот. Суть часткового забезпечення полягала в тому, що банкноти, не будучи забезпеченими всім золотим запасом, все ж підлягали обміну на золото за встановленим курсом. Проблеми могли виникнути тільки в разі, якби до обміну було б пред'явлено більшу кількість банкнот, ніж перебувало під забезпеченням, чого в реальності статися просто не могло;

3) банкноти без покриття - це нічим не забезпечені грошові знаки, обмін яких на золото не проводиться.

У процесі своєї еволюції банкноти поступово втрачали золоте забезпечення, тож країни-учасниці Міжнародного Валютного Фонду у 1976-1978 рр. на Ямайській конференції домовилися відмовитися від золотого забезпечення національних валют. Таким чином, сучасні грошові знаки більше не розмінні на золото. Ще однією особливістю сучасного етапу розвитку грошових форм став перехід грошових знаків із готівкової в переважно безготівкову форму. Безготівкові гроші - це записи, які відображають баланс рахунку, відкритого у фінансових установах. Виконуючи функції засобу обігу і засобу платежу, гроші можуть переходити з готівкової форми в безготівкову, і навпаки. Тут необхідно відзначити, що безготівкові гроші, не існуючи в реальному світі, є юридичною фікцією.

Отже, охарактеризувавши гроші з економічного погляду, а також простеживши еволюцію грошових форм, перейдемо до визначення правової природи грошей. Виступаючи як юридична категорія, гроші стають об'єктом правового регулювання різних галузей, насамперед фінансового та цивільного права. Тим часом підходи до розуміння грошей у цих галузях відрізняються один від одного.

Так, довго у правовій науці переважав цивілістичний підхід, який багато в чому був сприйнятий і наукою фінансового права. На наш погляд, це було пов'язано з існуючою за радянських часів недооцінкою як галузі фінансового права, так і самої категорії грошей як фінансово-правової категорії. Наука фінансового права не звертала уваги на праці своїх дореволюційних представників, і лише останнім часом у зв' язку зі зміною державного ладу ситуація почала виправлятися. 
Відповідно до ст. 177 Цивільного кодексу України об'єктами цивільних прав є речі, у т. ч. гроші та цінні папери, інше майно, майнові права, результати робіт, послуги, результати інтелектуальної, творчої діяльності, інформація, а також інші матеріальні та нематеріальні блага. Таким чином, можна зробити висновок, що для теорії цивільного права гроші - це насамперед річ, тобто предмет матеріального світу. Головне призначення речі полягає в задоволенні потреб суб'єктів цивільного права. Відповідно до цивільно-правової концепції гроші належать до:

1) рухомих речей. Відповідно до ч. 2 ст. 181 Цивільного кодексу України рухомими речами $є$ речі, які можна вільно переміщувати у просторі. Отже, речі, що не належать до нерухомості, включаючи гроші та цінні папери, визнаються рухомим майном. Реєстрація прав власності на рухомі речі не потрібна, крім випадків, зазначених у законі;

2) споживаних речей. Споживання грошей багато в чому умовне і не означає їx негайного знищення у процесі такого споживання. Воно полягає в перетворенні грошей в іншу річ, що зумовлено виконуваною грошима функцією засобу обігу;

3) родових речей, тобто вони характеризуються ознаками, загальними для всіх речей свого роду. Як відзначав Л.А. Лунц, будучи родовими речами, гроші визначаються в цивільному обігу не за своїми фізичними властивостями, а виключно за кількісним відношенням до певної абстрактної одиниці; цю властивість гроші поділяють з іноземною валютою і з деякими видами цінних паперів [5, с. 103];

4) будучи родовими, споживаними речами, гроші мають властивість замінності. Так, наприклад, якщо грошове зобов' язання слід виконати в іноземній валюті, то його можна виконати в національній валюті України;

5) ділених речей - гроші можуть бути поділені без майнової шкоди та зберігають свою платіжну силу. Абсолютно зрозуміло, що при розподілі готівки поділяється не саме фізичний носій (хоча раніше, в період існування товарних грошей, існувала і така практика), а їхнє числове значення.

Таким чином, із погляду цивільного права гроші є рухомі, споживані, родові, замінні, ділені речі. Звісно, таке розуміння грошей грунтується насамперед на їхній функції засобу обігу. Володіючи «абсолютною корисністю», гроші виступають як універсальне знаряддя обігу, що проявляється у їхній здатності обмінюватися на будьякі інші товари. Отже, цивільне право виходить із товарної природи грошей.

Однак таке розуміння грошей не може задовольнити науку фінансового права. У зв' язку з цим необхідно процитувати В.А. Лебедєва, котрий вказував на те, що назвати гроші товаром можна лише тоді, коли вони металеві, тобто не гроші самі по собі товар, а той метал, із якого вони зроблені [4, с. 408].

Водночас речова концепція грошей більше не влаштовує і науку цивільного права, оскільки, виходячи з буквального тлумачення ст. 192 Цивільного кодексу України, відповідно до якої законним платіжним засобом, обов' язковим до приймання за номінальною вартістю на всій території України, є грошова одиниця України - гривня, грошима можуть бути визнані лише готівкові грошові знаки. Безготівкові гроші не мають матеріального вираження ззовні, тобто не закріплені на паперовому або металевому носії, а отже, не можуть бути визнані грошима. Дійсно, за часів створення вчення про гроші вони існували виключно у готівковій формі, тобто найбільш логічно було віднести їх до речей. Поява безготівкових грошей призвела до переоцінки розуміння грошей, визнання їх більш складної природи порівняно 3 існуючими раніше уявленнями. Тут необхідно сказати, що сучасні цивілісти або зовсім не розглядають безготівкові гроші, або визнають їх майновими правами.

Таким чином, з усього вищесказаного випливає висновок про те, що наука цивільного права нині не може виробити єдину несуперечливу концепцію грошей. Подібне 
зауваження слід віднести до всієї правової науки загалом, бо, як вказував Л.А. Лунц, цивільний обіг створює знаряддя обігу, а держава - законний платіжний засіб [5, с. 105]. У зв' язку з цим поняття грошей у цивільному і фінансовому праві не можуть повністю збігатися. Ми ж наполягаємо на пріоритеті фінансово-правової складової частини грошей, говорячи про те, що гроші незалежно від форм існування насамперед виступають як фінансово-правова категорія і беруть участь у цивільному обороті, проте їхній фінансово-правовий режим є визначальним.

Нам видається, що багато дослідників зачіпали у своїх працях цю проблему, однак не враховували вищезазначеної обставини, намагаючись розробити універсальне визначення грошей, i, як наслідок, зазнавали невдачі. Надалі ми спробуємо дати характеристику грошей із фінансово-правового погляду.

Характеризуючи гроші як категорію фінансового права, необхідно виходити з їх державно-правової природи. Вказівку на це ми знаходимо ще в Аристотеля. Так, зокрема, він вказував на те, що «за загальною домовленістю з'явилася монета; тому й ім'я їй «номісма», що вона існує не за природою, а за вказівкою влади, і змінити їі або вивести з обігу влада може».

Ідея Аристотеля стала основою для зародження державно-правової теорії грошей. Вона була сприйнята і розвинена багатьма вченими. Так, ще В.А. Лебедєв у кінці 80-х pp. XIX ст. відзначав, що головна функція грошей полягає не в їх товарному значенні, а в санкції, що дається їм законом. Тож найкращі іноземні гроші не можуть бути законним і обов' язковим платіжним засобом, якщо вони не визнані законом певної держави. 3 іншого боку, закон може уповноважити до обігу гроші навіть і гіршої якості [4, с. 423].

Однак найбільш цілісне вчення про державно-правову природу грошей було створено на початку XX ст. німецьким вченим Г.Ф. Кнапом. Як він відзначав, нині платіжний механізм всюди регулюється нормами адміністративного права, які іє матеріалом для дослідження. Цілком очевидно, що те, що Кнапом було прийнято як адміністративні норми, насправді $є$ нормами фінансового права. Гроші є хартальним платіжним засобом (від Charta - знак), який отримує платіжну силу на підставі владної вказівки держави та визначається правовим порядком. Таким чином, держава оголошує певні предмети платіжним засобом і встановлює їх платіжну силу.

Вчення про державно-правову природу грошей було сприйнято і багатьма сучасними вченими, представниками науки фінансового права. Гроші є юридичною категорією, і без участі держави вони не можуть перебувати в обігу. О.Р. Денисов вказує, що сучасні гроші - це продукт права, оскільки вони мають свою здатність служити загальним еквівалентом у законодавчих актах держави та іiі органів влади [3, с. 184].

О.П. Орлюк визначає грошовий обіг як рух грошових коштів у процесі обслуговування економіки та соціальної сфери життя суспільства. Грошовий обіг $є$ частиною грошового обороту (тобто сукупності всіх грошових платежів у державі) та пов'язаний із обслуговуванням підприємств і організацій, фінансово-кредитних інститутів і населення, де гроші виконують функцію засобу обігу й засобу платежу, тобто відбувається рух готівки. Резюмуючи свої дослідження стосовно фінансово-правового аспекту поняття грошового обігу, науковець зазначає, що у фаховій літературі грошовий обіг розглядають як сукупність платежів, сукупність рухів грошової форми вартості у вигляді готівки та безготівкових розрахунків у процесі відтворення (виробництва, розподілу, обміну і споживання); як обіг законних платіжних засобів (банкнот, розмінної монети), що обслуговують потреби економіки; як постійний рух коштів, який охоплює сферу випуску (емісії) грошей НБУ та передачі їх у каси банків, а також подальше переміщення грошей у каси підприємств, установ, організацій, розрахунки 
3 населенням, здійснення ним платежів і внесків зі зворотним рухом до Національного банку України [7, с. 650-651].

Ю.А. Михальський зазначає, що грошовий обіг одночасно виступає і як необхідна умова функціонування сучасного суспільства, і як невід' ємна складова частина публічної фінансової діяльності. Враховуючи це, держава намагається врегулювати його як у межах своєї фінансової діяльності, так і загалом у всіх сферах суспільних відносин [6, с. 8].

Є.О. Алісов зазначає, що грошовий обіг як об'єкт фінансово-правового регулювання є безперервним рухом грошей при виконанні ними своїх функцій у готівковій і безготівковій формах, який обслуговує реалізацію товарів, а також нетоварні платежі та розрахунки в господарстві. Забезпечення безперервності руху грошей, його автоматизму є однією з головних цілей фінансової діяльності держави й одним із засобів ії здійснення, оскільки будь-яка держава є постійно діючим механізмом, а оскільки потреби держави в коштах для виконання властивих їй функцій і вирішення завдань безперервні, то це спричиняє об'єктивну необхідність безперебійного наповнення й витрат відповідних централізованих і децентралізованих фондів. Забезпечуючи свої власні потреби, держава у процесі здійснення фінансової діяльності сприяє безперервності грошового обігу і як особливому економічному процесу, i як сфері суспільного відтворення, забезпечуючи кругообіг вартості в економіці [1, с. 223-224].

Дійсно, з моменту випуску і до моменту вилучення з обігу гроші виступають об'єктом правового регулювання з боку держави, котра в особі законодавчих органів встановлює найменування і форми грошових знаків, що перебувають в обігу, визначає порядок розрахунків, встановлює правила зберігання, обміну та вилучення грошових знаків з обороту, а також регулює інші питання, пов'язані з обігом грошей. Функціонування держави як особливого механізму залежить від правильної побудови грошової системи, чого неможливо домогтися без введення єдиних, загальнообов' язкових правил iї організації. Дотримання таких правил гарантується державним апаратом примусу, i їх порушення тягне за собою відповідальність. 3 усього вищесказаного випливає, що гроші є об'єктом правового регулювання з боку держави.

Лише за собою держава визнає право на здійснення емісії грошових знаків, а також встановлення основ грошової системи. Таке виняткове право за своєю суттю представляє регалію.

Юридична конструкція регалій часто використовувалася представниками дореволюційної школи фінансового права. Пізніше радянська доктрина фінансово-правової науки надовго відмовилася від неї. Тим часом юридична конструкція регалій видається досить цікавою і корисною для наших цілей.

Сама назва «регалії» походить від латинського regalis - «царський». Поняття регалій із часом зазнавало значних змін. Сягаючи своїм корінням римського права, регалія перейшла в німецьке право. У середні віки під регалією розумілося верховне право держави (право держави здійснювати суд, справляти податки тощо), що випливало із самого поняття держави, іiї верховної влади над усіма громадянами і всією територією країни. Пізніше регалії були чітко осмислені та поділені на два види. Перший із них - regalia majora - включав у себе вищезазначені верховні права держави. Другий regalia minora - включав корисні фіскальні права, тобто права, що приносять дохід (jura itilia fisci).

У свою чергу, у дореволюційній науці фінансового права також склався певний погляд на поняття регалій. Так, Е.М. Берендтс визначав їх як «виняткове право держави на експлуатацію будь-якого підприємства промислового характеру з виключенням будь-якої приватної конкуренції, але не з метою одержання фіскальної вигоди, 
а 3 метою організації підприємства найбільш доцільним способом, що відповідало б публічним інтересам [2, с. 226].

I.I. Янжул вказував на те, що регаліями прийнято тепер називати такі казенні промисли, в яких держава має якусь перевагу перед підданими, або, іншими словами, такі промислові джерела доходу, якими держава користується переважно або виключно для себе, абсолютно не допускаючи приватної конкуренщії або ж значно обмежуючи останню [10, с. 136].

За своєю суттю регалія була чимось середнім між приватноправовими та публічно-правовими джерелами державних доходів. 3 одного боку, держава виступала як суб'єкт приватного права, з іншого - значною мірою обмежувала приватну конкуренцію. У зв'язку з цим регалії поділялися на:

1) регалії, за яких держава виступає нарівні з іншими суб'єктами цивільного обігу, не користуючись жодними перевагами суб'єкта публічного права. До цих регалій належали дорожня, порохова, порцелянова та ін.;

2) юридичні регалії, за яких держава або обмежувала, або повністю виключала приватну конкуренцію. Робилося це виключно в інтересах суспільства, щоб найкращим чином організувати промисли, які не могли бути у приватній власності. До цих регалій належали монетна, грошова, поштова, телеграфна та ін.;

3) фіскальні регалії - їхнє введення було зумовлено виключно фіскальними цілями. По суті, такі регалії можуть здійснюватися як регалії першого виду, тобто без обмеження конкуренції, i ïx введення не повинне залежати від публічного інтересу. До цих регалій належали гірська, соляна, тютюнова та ін. Такий вид регалій також називається фіскальною або казенною монополією.

Як ми бачимо, для цілей цього дослідження найбільший інтерес становить другий вид - юридичні регалії. Їхнє введення зумовлено суспільним, економічним, політичним і будь-яким іншим інтересом, відмінним від фіскального. Таким чином, юридична регалія не припускала вилучення доходу і спрямована була на сприяння народному добробуту.

У категорії юридичних грошових регалій найчастіше виділяли монетну регалію, рідше - регалію на випуск паперових грошей.

Так, під монетною регалією розумілося виняткове право держави карбувати монети і пускати їх в обіг. Монетна регалія була підставою для здійснення державою законодавчого регулювання випуску в обіг монет, визначення їх найменування, матеріалу, 3 якого виготовляються такі монети, проби, ваги, розміру, графічного зображення тощо. Названий вид регалій дозволяв державі отримувати у скарбницю певний дохід. До дохідних джерел монетної регалії належали:

1) власне монетний дохід, що отримується за допомогою встановлення мита, яке справлялося за перетворення металу в монету. Сума такого мита зазвичай не перевищувала суми витрат, зроблених у зв' язку з карбуванням монет;

2) дохід від карбування розмінної (білонної) монети;

3) дохід, що отримується шляхом встановлення переважного права купівлі дорогоцінних металів, використовуваних для карбування монет, за певною державою ціною, яка була нижчою за ринкову (jus praeemtionis). Різниця між встановленою та ринковою цінами становила дохід держави;

4) плата за пробірування і таврування золотих і срібних речей;

5) дохід від псування монети. Карбування неповновагової монети або випуск знецінених грошей було найбільш поширеним способом отримання доходів із монетної регалії. Безперечно, такий спосіб отримання доходу не можна віднести до легальних псування монет було досить негативною практикою, яка свідчила про розлад грошової системи країни, однак такий спосіб отримання доходів існував. 
Слід сказати, що отримання доходу при карбуванні золотих і срібних монет не було основною метою. Вважалося, що карбування монети є послугою, яка надається державою суспільству, що полягає в тому, що держава полегшує приватним особам ведення господарства шляхом належної організації монетного обігу, але за яку держава не стягує певної плати.

Тут необхідно зазначити, що нині монетна регалія вже не відіграє тієї ролі, як у період існування системи золотого монометалізму. Зараз монети більше не карбуються 3 дорогоцінних металів, а та незначна їх частина, яка все ж продовжує виготовлятися із благородних металів, зазвичай не використовується в обігу і призначена для колекціонування.

E.M. Берендтс, крім монетної регалії, відносив до державних регалій також виключне право держави випускати паперові гроші, кредитні білети. Він підкреслював, що випуск в обіг паперових грошей джерелом доходу не служить і служити не зможе [2, с. 255].

Таким чином, грунтуючись на аналізі сформованого в дореволюційній науці фінансового права вчення про регалії, ми доходимо висновку про необхідність виділення державної грошової регалії.

Джерело свого існування грошова регалія, безсумнівно, знаходить у державному суверенітеті, який полягає у верховенстві державної влади, в ії єдності та незалежності. Верховенство державної влади на всій території країни насамперед проявляється у можливості такої влади здійснювати правове регулювання суспільних відносин на всій території держави. Отже, звідси випливає і верховне право держави здійснювати правове регулювання грошового обігу в країні. Наявність добре налагодженої, справно функціонуючої грошової системи є запорукою збереження державою свого суверенітету.

В історії нерідко трапляється, коли країни, котрі володіли слабкою валютою, впадали в залежність від свого більш сильного в цьому відношенні сусіда. Багатьом державам, які не зуміли належним чином налагодити грошовий обіг, доводилося (i доводиться) користуватися у внутрішньому обігу іноземною валютою, більш твердою і сильною порівняно з національною. Таким чином, такі держави перестають бути «господарями своїх грошей», а це неминуче веде до підриву суверенітету і довіри до державної влади.

Отже, для збереження і підтримання свого суверенітету держава бере на себе функцію правового регулювання грошового обігу. Таке право держава визнає виключно за собою, і жодна приватна особа не може випускати в обіг інші грошові знаки, які визнавалися б законним платіжним засобом на території країни, або ж підробляти грошові знаки, встановлені законом, що гарантується системою державного примусу. Цілком очевидно, що жодна приватна особа не в змозі впоратися із функцією організації грошового обігу у країні.

Таким чином, під державної грошової регалією ми розуміємо засноване на суверенітеті виключне право держави встановлювати найменування та види грошових знаків, що використовуються як законний засіб платежу на ії території, а також ії виняткове право визначати правила обігу таких грошових знаків, починаючи 3 моменту випуску їх і закінчуючи моментом вилучення грошових знаків з обігу.

Виступаючи як правова категорія, гроші характеризуються рядом ознак, що виявляють їх юридичну природу.

По-перше, гроші є особливими знаками, вираженими у формі, встановленій законом. Держава за допомогою правового регулювання визначає, які знаки є законним платіжним засобом на їі території. Крім того, вона закріплює найменування націо- 
нальної грошової одиниці. Такі найменування складаються у процесі тривалого історичного розвитку видів і форм грошей у кожній конкретній державі та є частиною іiї національної культурної традиції. Саме держава закріплює ці найменування як офіційні.

Також законодавством визначаються види грошових знаків. Класифікація грошей може бути проведена за різними підставами.

Залежно від матеріального вираження гроші поділяють на:

1) готівкові - грошові знаки, що існують у реальному світі, виражені в матеріальній формі банкнот або металевої монети;

2) безготівкові, що становлять записи на рахунках у фінансових установах, з чого випливає, що вони не мають зовні матеріального вираження.

Залежно від органу влади, який здійснює емісію, виділяють:

1) казначейські грошові знаки, які випускаються казначейством;

2) грошові знаки, що випускаються емісійним банком.

Крім того, залежно від національної належності гроші поділяються на:

1) національну валюту - грошові знаки держави, випуск яких визнаний законним платіжним засобом на всій його території;

2) іноземну - гроші, що випускаються іноземною державою.

Залежно від конвертованості, тобто від здатності валюти обмінюватися на іноземну валюту, виділяють:

1) неконвертовану валюту, що не підлягає обміну;

2) частково (обмежено) конвертовану валюту - існує в країнах, у яких встановлена система валютних обмежень (наприклад, заборонене ввезення і вивезення валюти за межі країни, обмежена можливість володіння, користування і розпорядження коштами в іноземній валюті тощо). До частково конвертованої валюти належить і українська гривня;

3) вільно конвертовану валюту, обмін якою на інші валюти відбувається без якихось обмежень. Така валюта вільно обертається на світовому валютному ринку.

По-друге, держава встановлює платіжну силу грошових знаків. Платіжна сила товарних грошей більшою мірою визначалася вартістю дорогоцінного металу, що використовувався для їх виготовлення, тобто це була їхня внутрішня властивість. Сучасні гроші, втративши свою товарну природу, більш не володіють внутрішньою платіжною силою. Вона, з одного боку, гарантується державою, яка гарантує платоспроможність національної валюти, а з іншого - закріплюється (позначається) нею за допомогою фінансово-правових норм на грошових знаках. Таким чином, оскільки сучасні гроші не мають внутрішньої вартості, обов'язковість їх прийняття як засобу платежу гарантується державною владною вказівкою.

Платіжна сила позначається в кількості національних грошових одиниць, які виконують функцію рахункової одиниці. Таким чином, за допомогою грошової одиниці можна легко і швидко виміряти вартість будь-якого товару або послуги, тобто дізнатися їхню ціну. Щоб кількісно порівняти ціни різних за своєю природою товарів, робіт, послуг, вони повинні бути виражені в однакових грошових одиницях.

Крім того, держава встановлює внутрішню будову грошової одиниці. Це виражається в тому, що законодавець вводить більш дрібну грошову одиницю, певне число якої становить основну грошову одиницю. Наприклад, в Україні за Конституцією грошовою одиницею є гривня, яка складається зі 100 копійок.

Держава також вибирає масштаб розподілу грошової одиниці. У більшості країн існує десяткова система ділення. Так, 1 долар США складається зі 100 центів, 1 євро дорівнює 100 євроцентам. Однак в історії є випадки, коли розподіл відбувався більш 
складним шляхом. Наприклад, до 1971 р. 1 англійський фунт стерлінгів складався iз 20 шилінгів, 1 шилінг, у свою чергу, дорівнював 12 пенсам, 2 шилінги становили флорин, а монета у 5 шилінгів - крону. Нині 1 фунт стерлінгів дорівнює 100 пенсам. Таким чином, масштаб розподілу грошової одиниці також встановлюється законом.

По-третє, важливою ознакою, що характеризує гроші як правову категорію, є монопольне право держави на емісію грошових знаків. Це право прямо випливає з державної грошової регалії.

По-четверте, гроші реалізують свої економічні функції тільки за допомогою юридичних, насамперед фінансово-правових норм. 3 цього ми робимо висновок, що поза правом сучасні гроші не здатні виконувати вищезазначені економічні функції.

Таким чином, із погляду фінансового права гроші можуть бути визначені як особливі знаки, чиє найменування закріплено в нормативно-правових актах, відповідно до яких таким знакам надається платіжна сила, виражена в кількості грошових одиниць, а також визначається порядок емісії й обігу, щоб вони служили законним платіжним засобом на всій території держави.

Ми розуміємо, що подібне визначення може бути далеким від досконалості та не враховувати багатьох аспектів такої складної категорії, як гроші. Проте всі вищевказані аспекти просто не можуть бути повністю враховані, щоб дати всебічне і несуперечливе визначення грошей. Наше визначення, не претендуючи на універсальність, надалі відіграватиме службову роль у розгляді проблем грошового обігу.

Так, доцільно визначити співвідношення таких понять, як «гроші», «валюта» i «грошові сурогати». За найпоширенішою версією, слово «гроші» походить від назви монгольської монети «диргеми» або «денга» («дзвінкі»). Такі монети використовувалися у внутрішньому обігу князівств у період монголо-татарської навали. Це було зумовлено, з одного боку, залежністю князівств від Золотої орди, а з іншого - браком власних дорогоцінних металів для насичення внутрішнього ринку. Пізніше грошима стали називати дрібну розмінну монету, і поступово їі назва стала загальною.

Слово валюта походить від італійського valuta - «вартість», яке сягає корінням латинського valeo - «стою». У Великій Радянській Енциклопедії валюта визначається як:

1) грошова одиниця країни та ії тип (золота, срібна, паперова);

2) грошові знаки іноземних держав, а також кредитні та платіжні документи, які виражені в іноземних грошових одиницях (векселі, чеки тощо) і використовуються в міжнародних розрахунках (іноземна валюта).

У свою чергу, Словник української мови розуміє валюту як грошову одиницю, що використовується для вимірювання величини вартості товару. Поняття «валюта» використовується у трьох значеннях:

- національна валюта - грошова одиниця країни (українська гривня, американський долар та ін.);

- іноземна валюта - це грошові знаки іноземних держав;

- міжнародна (регіональна) валюта - це спеціальні права запозичення (СПЗ) та євро.

Валюта залежно від режиму використання поділяється на конвертовану і неконвертовану, від сфери і цілей використання - на валюту платежу, валюту ціни, валюту операцій, валюту клірингу, валюту векселя.

Як ми бачимо, слово «валюта» має відтінок іноземного елемента у відносинах, що виникають із приводу й у зв'язку із грошима. Дійсно, слово «валюта» у повсякденній мові вживається для позначення іноземних грошей. Ю.А. Михайльський відзначає, що валютою є гроші, включені в міжнародні економічні відносини [6, с. 9]. Наприклад, українська гривня на території України є внутрішньою валютою, національ- 
ними грошима, але за ії межами вона вже виступає як іноземні валюті для представників тієї держави, на території якої вони обертаються.

Таким чином, ми можемо зробити висновок, що поняття «гроші» та «валюта» $\epsilon$ синонімами. Аналогічної позиції дотримується і законодавець. Підтвердження цього висновку ми знаходимо у ст. 1 Закону України «Про валюту і валютні цінності» від 21 червня 2018 р. № 2473-VIII, відповідно до якої іноземна валюта - це:

- грошові знаки грошових одиниць іноземних держав у вигляді банкнот, казначейських білетів, монет, що перебувають в обігу та є законним платіжним засобом на території відповідної іноземної держави або групи іноземних держав, а також вилучені або такі, що вилучаються з обігу, але підлягають обміну на грошові знаки, які перебувають в обігу;

- кошти на рахунках у банках та інших фінансових установах, виражені у грошових одиницях іноземних держав і міжнародних розрахункових (клірингових) одиницях (зокрема у спеціальних правах запозичення), що належать до виплати в іноземній валюті;

- електронні гроші, номіновані у грошових одиницях іноземних держав та (або) банківських металах;

- національна валюта (гривня):

- грошові знаки грошової одиниці України - гривні у вигляді банкнот, монет, у т. ч. обігових, пам'ятних і ювілейних монет, і в інших формах, що перебувають в обігу та є законним платіжним засобом на території України, а також вилучені або такі, які вилучаються з обігу, але підлягають обміну на грошові знаки, що перебувають в обігу;

- кошти на рахунках у банках та інших фінансових установах, виражені у гривні;

- електронні гроші, номіновані у гривні.

Таким чином, з усього вищесказаного ми можемо зробити висновок, що поняття «гроші» $\mathbf{i}$ «валюта» є синонімами.

Під грошовими сурогатами необхідно розуміти замінник грошей, використовуваний як засіб платежу. Грошовий сурогат - це будь-які документи у вигляді грошових знаків, що відрізняються від грошової одиниці України, випущені в обіг не Національним банком України і виготовлені з метою здійснення платежів у господарському обороті, крім валютних цінностей.

Поява грошових сурогатів зазвичай $є$ не результатом вільної конкуренції, а примусовою складовою частиною під страхом покарання. Якщо гроші не виконують хоча б одну з цих функцій, то швидше за все це грошовий сурогат, який примусово нав' язується людям за допомогою впливу держав.

Головною особливістю грошових сурогатів є їхня обмежена ліквідність, що означає, що не будь-який платіж може бути здійснений із їх допомогою. Вони можуть використовуватися виключно для розрахунків між приватними особами, якщо між ними існує така домовленість. Жодна особа не може бути примушена здійснювати платіж грошовими сурогатами або ж, навпаки, прийняти такий платіж. Грошові сурогати не можуть бути прийняті як платіжний засіб при розрахунках із державою або органами місцевого самоврядування, комунальними та державними підприємствами.

Найчастіше до грошових сурогатів відносять векселі та чеки. Відповідно до чинного законодавства України вони є цінними паперами.

У період політичної нестабільності в державі може мати місце обіг так званих «регіональних» грошей. Наприклад, на території колишньої Російської імперії у період із 1918 по 1924 рр. у грошовому обігу перебували грошові знаки, випущені на місцях білими урядами, урядами самопроголошених національних республік, а також окремими банками та кооперативами. Так, наприклад, власні гроші друку- 
вали в Україні з 1917 по 1919 рр., На Закавказзі з 1918 р. по 1924 р., на Далекому Сході й у Сибіру - аж до $1921 \mathrm{p}$.

До грошових сурогатів може бути віднесена й іноземна валюта, але тільки у випадках, коли вона використовується як платіжний засіб із порушенням встановлених правил здійснення розрахунків іноземною валютою.

Загалом можна сказати, що грошові сурогати поширюються в періоди розладу системи грошового обігу. У випадках, коли грошових коштів або не вистачає, або до них втрачено довіру, розрахунки відбуваються з використанням грошових сурогатів. Поширення грошових сурогатів призводить до того, що вони заміщають національну валюту.

Висновки. Гроші як об'єкт фінансово-правового регулювання можуть бути визначені як особливі знаки, чиє найменування закріплено в нормативно-правових актах, відповідно до яких таким знакам надається платіжна сила, виражена в кількості грошових одиниць, а також визначається порядок емісії й обігу з тим, щоб вони служили законним платіжним засобом на всій території держави.

\section{Список використаних джерел:}

1. Алісов С.О. Проблеми правового регулювання грошового обігу в Україні : дис. ... докт. юрид. наук : 12.00.07. Харків, 2006. 445 с.

2. Берендтс Э.Н. Русское финансовое право. Санкт-Петербург : Типо-лит. С.-Петербургской Одиночной тюрьмы, 1914. 320 с.

3. Денисов Е.Р. Основные направления совершенствования финансово-правового регулирования денежной системы РФ. Проблемы финансового права в условиях рынка $b$ XXI веке : сборник материалов международной научно-практической конференции / отв. ред. О.Н. Горбунова. Москва : ТК «Велби», Изд-во «Проспект», 2005. 235 с.

4. Лебедев В.А. Бумажные деньги. Речь, читанная на акте Императорского С.-Петербургского университета 8 февраля 1889 г. профессором В.А. Лебедевым. Финансовое право : учебник. Москва : Статут, 2000. 520 с.

5. Лунц Л.А. Деньги и денежные обязательства в гражданском праве. Москва : Статут, 2004. 285 с.

6. Михальський Ю.А. Фінансово-правове підгрунтя грошового обігу. Науковий вicник Ужгородського національного університету. Серія Право. 2016. Вип. 38. Т. 2. С. 7-10.

7. Орлюк О.П. Фінансове право. Академічний курс : підручник. Київ : Юрінком Інтер, 2010. 808 с.

8. Ровинский Е.А. Основные вопросы теории советского финансового права. Москва : Госюриздат, 1960. 280 с.

9. Сталин И.В. Вопросы ленинизма. Москва : Госполитиздат, 1945. 620 с.

10. Янжул И.И. Основные начала финансовой науки: учение о государственных доходах. Москва : Статут, 2002. 290 с. 


\title{
РОЗШИРЕНЕ РОЗУМІННЯ ЕЛЕКТРОННОГО УРЯДУВАННЯ У СУЧАСНІЙ ПРАВОВІЙ СИСТЕМІ
}

\author{
Романчук Ольга Захарівна, \\ здобувач кафедри конституційного \\ права та порівняльного правознавства \\ (Ужгородський національний \\ університет, м. Ужгород, Україна)
}

Технологічні ресурси весь час розвиваються, знаходячи все ширшу сферу апробації, серед них - оновлення форми управління у публічно-владній сфері. Цифровий уряд розпочав значні та тривалі зміни у способі життя людей і їхній взаємодії між собою та громадськими інституціями. Інформаційні технології та інновації впливають на суспільний сектор і змінюють повсякденне життя людей.

Проаналізовано чинне нормативне законодавство, яке визначає понятійно-категоріальний апарат електронного урядування. Вказано, що поняття, яке детерміновано в законодавстві, є застарілим, оскільки не відображає сучасних тенденцій і має низку недоліків.

По-перше, воно містить декларативні широкі категорії, опосередковано визначає основну сутність поняття - послуги надаються через інформаційні-комунікативні технології.

По-друге, незрозуміло, що мав на увазі нормотворець, визначаючи «для формування нового типу держави». Говорити про новий тип держави в широкому розумінні не зовсім правильно, оскільки, незважаючи на впровадження електронної комунікації, держава продовжує мати такий самий тип виробництва, традиційні способи отримання прибутку, користування власністю та традиційні форми надання послуг.

По-третє, акцентується увага на задоволенні потреб громадян. Вказане не є доречним, оскільки електронне урядування сьогодення - це система, яка характеризує дуже широку сферу відносин органів публічної влади та фізичних осіб (до того ж, це не завжди громадяни, це можуть бути іноземці, особи без громадянства, біженці, оскільки для них також працюють широкі сервісні послуги), а також юридичних осіб, тому що налагодження відносин влади та бізнесу також входить до новітньої системи урядування.

Доведено, що сьогодні електронне урядування слід розуміти масштабніше, ніж надання електронних послуг технічними засобами, оскільки урядування набагато розширило сферу застосування шляхом включення участі всіх зацікавлених суб'єктів та участі в управлінні.

Акцентуємо на тенденції до розширення системи електронного урядування, що передбачає не тільки збільшення сфер і видів послуг, але й суб'єктів взаємодії. Нині електронне урядування вийшло за територіальні межі держави. Колективні глобальні зусилля зосереджені на більшому визнанні інституційних зв' язків між економічними, соціальними й екологічними аспектами сталого розвитку, тому електронне врядування використовується не тільки на національному та регіональному рівні, але і як ресурс у досягненні вищих життєвих рівнів для майбутніх поколінь у всьому світі.

Така міжнародна сфера проявляється принаймні в тому, що електронне урядування покращує інформування обговорень міждержавних органів; сприяє боротьбі 3 глобальними катастрофами та кіберзлочинністю.

Ключові слова: електронне урядування, тип держави, державне управління, публічні послуги. 


\title{
EXTENDED UNDERSTANDING OF E-GOVERNMENT IN THE CURRENT LEGAL SYSTEM
}

\author{
Romanchuk Olha Zakharivna, \\ PhD Student at the Department of \\ Constitutional Law and Comparative \\ Legislature \\ (Uzhhorod National University, \\ Uzhhorod, Ukraine)
}

Technological resources are constantly evolving, finding an ever-expanding scope of testing, among them a renewed form of governance in the public-power sphere. The digital government has initiated significant and lasting changes in people's lifestyles and their interactions with one another and public institutions. Information technology and innovations affect the public sector and change people's daily lives.

The current regulatory legislation that defines the conceptual and categorical apparatus of e-government is analyzed. It is stated that theconcept, which is determined in thelegislation, is primarily obsolete, since it does not reflect current trends and has several disadvantages.

Firstly, it contains declarative broad categories, while indirectly defining the basic essence of the concept - services are provided through information and communication technologies.

Secondly, it is not clear what the lawmaker meant by defining "to form a new type of state". At the same time, to speak of a new type of state in the broad sense is not entirely true, because despite the introduction of electronic communication, the state still has the same type of production, there are traditional ways of profit, use of property and still there are traditional forms of services.

Thirdly, the focus is on meeting the needs of citizens. This is not entirely true, as e-government today is a system that characterizes a very broad sphere of relations between public authorities and individuals (moreover, it is not always citizens, it can be foreigners, stateless persons, refugees, since for them also work broad services) as well as legal entities, as the establishment of relations between government and business is also part of the newest system of government.

It has been proven that e-governance today is to be understood more broadly than the provision of e-services by technical means, as governance has expanded its scope to a greater extent by involving all stakeholders and participating in governance.

We emphasize the tendency for the expansion of the e-government system, which envisages not only the increase of spheres and types of services, but also the subjects of interaction. Nowadays e-government has gone beyond the territorial borders of the state. Collective global efforts focus on greater recognition of the institutional linkages between economic, social and environmental aspects of sustainable development, so e-government is used not only at national and regional level, but also as a resource in achieving higher standards of living for future generations worldwide.

Such an international sphere is reflected in at least the following: e-government improves facilitating and informed discussions between intergovernmental bodies; fight against global catastrophes and cybercrime.

Key words: e-government, type of state, public administration, public services.

Постановка проблеми. Сьогодні суспільство перебуває у критичному переході, в середині цифрової революції, яка стосується не лише технологій і відіграє важливу роль у житті людей і держав. Технологічний прогрес відбувається у всіх сферах сус- 
пільного життя, від розвитку штучного інтелекту до розвитку біомедицини та генної інженерії. Технологічні ресурси весь час розвиваються, знаходячи дедалі ширшу сферу апробації, серед них і оновлення форми управління у публічно-владній сфері. Цифровий уряд розпочав значні та тривалі зміни у способі життя людей і їхній взаємодії між собою та громадськими інституціями. Інформаційні технології та інновації впливають на суспільний сектор і змінюються повсякденне життя людей.

Незважаючи на актуальність проблематики, законодавча база в Україні має ряд недосконалостей, серед яких, зокрема, питання удосконалення понятійно-категоріального апарату у сфері електронного урядування.

Стан дослідження. Проблемою відкритості та доступності органів публічної влади займалися представники як теоретичної юриспруденції, так і конституційного й адміністративного права, зокрема О. Дніпров, О. Зарічний, І. Жаровська, В. Ковальчук, Ю. Бисага, Д. Бєлов, О. Скрипнюк та ін. Проте активне впровадження системи електронного урядування потребує додаткового аналізу проблемних питань у цій сфері.

Метою статті $є$ аналіз питань розширеного розуміння електронного урядування у сучасній правовій системі.

Виклад основних положень. Хоча термін «електронний уряд» з'явився більше двадцяти років тому, загальновизнаної дефініції не існує. Визначення, найпоширеніше в іноземній літературі, взяте з дослідження Лейна та Лі: «Електронний уряд стосується використання урядом технологій, зокрема веб-додатків для Інтернету, для розширення доступу до громадянської та бізнес-служб і надання їм урядової інформації та послуг для партнерів, працівників, інших агенцій та урядових установ» [1, с. 123].

Згодом іноземні автори визначають електронне врядування через систему надання публічних послуг, тобто «використання інформаційних технологій (далі - IT), інформаційно-комунікаційних технологій (далі - IKT) та ін. телекомунікаційних технологій на базі веб-технологій для вдосконалення та / або підвищення ефективності надання послуг у державному секторі» [2].

Міжнародні інституції також звертають увагу на теоретичні поняття, так, Організація економічного співробітництва та розвитку позиціонує електронний уряд як «використання IKT, зокрема Інтернету, як інструменту для покращення управління державою» [3].

Доктринальні положення дуже різняться. І. Колесніченком було визначено й узагальнено основні підходи до розуміння поняття «електронний уряд». Перший підхід розглядає електронний уряд як електронний сервіс надання державних послуг. Він спирається на поширену практику перенесення ефективних IКТ регулювання зі сфери бізнесу у громадський сектор, що забезпечує вихід на новий рівень якості надання послуг, зручності для користувачів за одночасного скорочення трансакційних витрат. Представники другого підходу розглядають електронний уряд як високотехнологічну організацію, функціонування якої забезпечується сучасними засобами IКТ. Цей підхід виходить із перспектив інформаційної епохи, коли тільки організація всієї діяльності уряду на основі IКТ може забезпечити трансформацію суспільного сектора відповідно до нових вимог часу. Третій підхід розглядає електронний уряд як нову модель регулювання, адекватну емерджентній економіці та інформаційному суспільству. Це не просто ширше тлумачення, яке поглинає перші два підходи, а принципово новий погляд на зміст інститутів влади, держави й організацію державного регулювання [4].

Національне законодавство визначається з понятійними категоріями таким чином. Відповідно до Концепції розвитку електронного урядування в Україні (2017 р.) «електронне урядування - форма організації державного управління, яка сприяє підви- 
щенню ефективності, відкритості та прозорості діяльності органів державної влади й органів місцевого самоврядування з використанням IKT для формування нового типу держави, орієнтованої на задоволення потреб громадян» [5]. Звернемо увагу, що первинно така сама дефініція містилася в Розпорядженні КМУ «Про схвалення Концепції розвитку електронного урядування в Україні» (2010) [6].

Таке поняття, детерміноване в законодавстві, є застарілим, оскільки не відображає сучасних тенденцій і має, на нашу думку, низку недоліків:

По-перше, воно містить декларативні широкі категорії, опосередковано визначає основну сутність поняття - послуги надаються через IKT.

По, друге, незрозуміло, що мав на увазі нормотворець, визначаючи «для формування нового типу держави».

Поняття типу держави розглядається в загальнотеоретичній юриспруденції. Тип держави - сукупність держав, які мають схожі загальні риси, що проявляються в єдності закономірностей і тенденщій розвитку, грунтуванні на однакових економічних (виробничих) відносинах, на однаковому поєднанні загальносоціального і вузькогрупового (класового) аспектів їх сутності, аналогічному рівні культурно-духовного розвитку [7].

Виокремлюють широку класифікацію типів держав: за рівнем захисту прав і свобод людини (правові та неправові); за способом набуття влади (легітимні, нелегітимні); за історичним підходом (рабовласницька, феодальна, буржуазна, соціальної демократії, соціально-демократичної орієнтації, соціальної демократії); за цивілізаційним підходом (первинні, вторинні) тощо. Н. Крестовська виокремлює також скарбницю як критерій типології (дантські, рентні, податкові) [8]; Д. Герилів вказує на інтегративний підхід (східний, рабовласницький, феодальний, капіталістичний і соціалістичний) [9, с. 14]. Отож, незрозуміло, прояв якого типу з поданої класифікації (яка, до речі, може бути більшою) має на увазі нормотворець.

По-третє, акцентується увага на задоволенні потреб громадян. Вказане не є правильним, оскільки електронне урядування сьогодення - це система, яка характеризує дуже широку сферу відносин органів публічної влади та фізичних осіб (до того ж, це не завжди громадяни, це можуть бути іноземці, особи без громадянства, біженці, оскільки для них також працюють широкі сервісні послуги), а також юридичних осіб, тому що налагодження відносин влади та бізнесу також входить у новітню систему урядування.

Електронне врядування включає надання послуг у різних сферах, зокрема прийнято виділяти:

- електронне управління, зосереджене на внутрішньодержавному процесі управління (G2G);

- електронні послуги, орієнтовані на надання державних послуг громадянам і бізнесу (G2C / G2B);

- електронне громадянство, орієнтоване на вклад громадян і бізнесу в управління (C2G, B2G) [10, с.1916].

Ось як цю систему описує А. Мєзєнцев. «Електронне урядування складається із трьох важливих елементів взаємодії: взаємодії держави та громадянина, взаємодії держави та бізнесу, взаємодії органів влади. Громадяни отримують доступ до публічної інформації, білыш якісні й оперативні адміністративні послуги, мати можливість впливу на прийняття і реалізацію важливих державних рішень. Бізнес отримує спрощений, більш швидкий доступ до органів державної влади, що допоможе більш ефективно і результативно співпрацювати бізнесу і владі. Органи влади отримують можливість координувати свої дії, більш ефективно й оперативно вирішувати ті чи інші завдання, підвищити якість надання адміністративних послуг, бути відкритими 
та прозорими, чуткими та гнучкими до вимог громадян і бізнесу. Перехід до електронного урядування означає трансформацію усіх форм діяльності органів влади, зміну їх структури, завдань і функцій. Успіх реалізації цього переходу залежить від правильної стратегії та тактики, координації та ефективної взаємодії усіх суб'єктів цього процесу, а саме: законодавчої, виконавчої та судової гілок влади, бізнесу та громадськості» $[11$, с. 65]

Тому сьогодні електронне урядування слід розуміти масштабніше, ніж надання електронних послуг технічними засобами, оскільки урядування набагато розширило сферу застосування шляхом включення участі всіх зацікавлених суб'єктів та участі в управлінні. Електронне урядування виступає ефективним інструментом для досягнення кращого управління. Тому з часом національні уряди пропонують цілу низку нових IKT для трансформації влади на основі демократії, інклюзивності та демонструють високі результати діяльності.

Поряд із цим говорити про новий тип держави в широкому розумінні не зовсім доречно, оскільки, незважаючи на впровадження електронної комунікації, держава продовжує мати такий самий тип виробництва, традиційні способи отримання прибутку, користування власністю та традиційні форми надання послуг. Тим не менш, оновлена система управління передбачає оновлену політику, орієнтовану на широке використання цифрового суспільства й економіки через орієнтацію на інформативний розвиток, орієнтований на людей.

Електронне урядування визначено як форму організації державного управління, тобто вона зазвичай має національний характер. I справді, загалом вказана система залежить від внутрішньодержавних чинників - першочергово економічного розвитку.

Багато розвинених країн інвестували значні кошти ресурси та зусилля для удосконалення інструментів електронного уряду, пошуку інноваційних способів їх використання для ефективнішого надання публічних послуг. Країни з нижчим рівнем розвитку стикаються з браком економічних ресурсів для розробки та впровадження технологій, що створює більший розрив між країнами щодо рівня застосування електронного уряду з метою кращого управління.

Відповідно до опитування ООН 2018 р. нині існують великі відмінності серед регіонів світу з погляду готовності електронного уряду. Свропа має очевидну перевагу перед іншими регіонами, за нею - Америка, Азія - трохи нижче середнього по всьому світу, Африка значно відстає.

Отож, електронне врядування передбачає можливість широкого доступу і самостійно створює перепони для такої відкритості, оскільки саме інформаційна доступність існує як первинна проблема. Нині відзначаємо негативну кореляцію між цифровим використанням і соціальним відчуженням. Інтернет-використання пропонує можливість електронного включення, але також ризикує новим цифровим розривом через недостатній доступ у країнах із низьким рівнем доходу або браком пристроїв чи ïx пропускної здатності та швидкості.

Як вказує заступник Генерального секретаря з економічних і соціальних питань ООН Л. Женьмін: «Доступ до нових технологій залишається невловимим для деяких регіонів і країн, особливо найбільш вразливих, зокрема країн Африки, найменш розвинених країн, малих острівних держав, що розвиваються, та країн, які розвиваються без виходу до моря. Там необхідно враховувати нові та безпрецедентні ризики. Без ретельного застосування дизайну та нагляду інструменти штучного інтелекту можуть завдати шкоди вразливим групам населення та посилити нерівність, розширюють цифровий розподіл і негативно впливають на робочі місця й економіку, а також на конфіденційність, відмову службових та інших питань кібербезпеки» [12, с. III]. 
За даними останнього світового огляду 2018 р. щодо електронного урядування, починаючи 32012 р. спостерігається постійне зростання кількості країн, веб-сайти яких з інформацією про конкретні програми приносять користь жінкам і дітям, особам з обмеженими можливостями, літнім людям, корінним людям і людям, які живуть у бідності. Дедалі частіше Держави-члени ООН вирішують потреби маргіналізованих груп через цільові втручання та надання послуг. Проте більшість світового населення залишається офлайн, що збільшує ризик, що вразливі групи без доступу до Інтернету ще більше відставатимуть у швидко прогресуючому цифровому суспільстві. Таким чином, технології можуть як сприяти, так і перешкоджати всебічній меті - нікого не залишати позаду [13, с. XXIV].

Електронне урядування має тенденцію до розширення, і цей процес є безперервним. Таке розширення передбачає збільшення не тільки сфер і видів послуг, але й суб'єктів взаємодії. Нині електронне урядування вийшло за територіальні межі держави. Колективні глобальні зусилля зосереджені на більшому визнанні інституційних зв' язків між економічними, соціальними й екологічними аспектами сталого розвитку, тому електронне врядування використовується не тільки на національному та регіональному рівні, але і як ресурс у досягненні вищих життєвих рівнів для майбутніх поколінь у всьому світі.

Цифрова взаємодія служить інструментом розвитку, щоб країни навчалися одна від одної, визначали сфери сили та виклики в електронному уряді та формували політику та стратегію в цій галузі.

Така міжнародна сфера проявляється у тому, що:

- електронне урядування покращує сприяння й інформування обговорень міждержавних органів, у т. ч. Генеральної Асамблеї Організації Об'єднаних Націй, ЕКОСОР, ЮНІСЕФ, ВООЗ та інших органів ООН;

- глобальні катастрофи, зокрема повені, циклони та тайфуни, а також посухи, мають транскордонний характер, міжрегіональний і глобальний обмін даними та координація між зацікавленими країнами та регіонами мають вирішальне значення. Партнерство сприяє особливо економічно незахищеним країнам, які можуть не мати достатнього бюджету чи персоналу взяти на себе відповідальність за всі етапи зменшення ризику стихійних лих;

- кібербезпека є ключовим фактором перетворення на стійкий електронний уряд. Заходи безпеки є першочерговими, їх потрібно стратегічно включати у функціонування системи електронного урядування з самого початку, на етапі проектування. Глобальний світ дедалі більше сприймає IKT як головний стимулюючий фактор соціально-економічного розвитку, проте попередження про нецільове використання викликає питання щодо державної безпеки та захисту осіб і підприємства, що переживають глобальний зв' язок.

У травні 2017 р. кібератака з використанням вірусу WannaCry спричинила великі перебої у критичній інформаційній інфраструктурі компаній і лікарень більш ніж у 150 країнах. 27 червня 2017 р. стартувала масова кібератака, яка здійснювалася за допомогою модифікованої версії вірусу «Wannacry» - Petya.A, що найбільше захопила Україну, але значно поширилася і на Голландію, Польщу, Францію. 2016, 2018 та 2019 рр. група Strontium виклала у відкритий доступ медичні записи та повідомлення електронної пошти, отримані від спортивних і антидопінгових посадових осіб. Внаслідок останньої атаки 6 національних і міжнародних спортивних та антидопінгових організацій на трьох континентах стали жертвами цих нападів. Отож, кібербезпека - важливий елемент електронного урядування, який може розвиватися й ефективно працювати виключно із застосуванням міжнародної взаємодії. 
Висновки. Пропонуємо таку дефініцію для національного законодавства. Електронне урядування - форма організації державного управління, що здійснюється шляхом використання IКТ і сприяє підвищенню ефективності, відкритості та прозорості діяльності органів публічної влади з метою системної взаємодії міжнародних і національних інституцій, населення, бізнесу.

\section{Список використаних джерел:}

1. Layne, K., Lee, J. Developing fully functional E-government: A four stage model. Government Information Quarterly. 2001. V. 18 (2), P. 122-136. URL: https://doi.org/10.1016/S0740-624X(01)00066-1.

2. Madzova V., Sajnoski K., Davcev L. E-Government as an Efficient Tool towards Good Governance (Trends and Comparative Analysis throughout Worldwide Regions and within West Balkan Countries). Balkan Social Science Review. 2013. Vol. 1. P. 157-174.

3. OECD. Promise and Problems of E-democracy. Challenges of Online Citizen Engagement. 2003. Paris: OECD Publishing. URL: http://www.oecd.org/gov/digitalgovernment/35176328.pdf.

4. Колесніченко I.M. Розвиток електронного урядування в Україні: інституціональний аспект Бізнес-Iнформ. 2014. № 3. URL: http:/ / business-inform.net.

5. Концепція розвитку електронного урядування в Україні: схв. розпорядженням Кабінету Міністрів України від 20 вересня 2017 р. № 649-p URL: https:/ / zakon.rada.gov.ua/laws/show/649-2017-\%D1\%80.

6. Про схвалення Концепції розвитку електронного урядування в Україні: Розпорядження Кабінету Міністрів України; Концепщія від 13 грудня 2010 р. № 2250-p URL: https:/ / zakon.rada.gov.ua/laws/show/2250-2010-\%D1\%80.

7. Скакун О.Ф. Теорія держави і права : підручник / пер. $з$ рос. Харків : Консум, 2001. 656 c.

8. Крестовська Н.М. Скарбниця як критерій типології держави Наукові пращі Національного університету «Одеська юридична академія». 2011. Т. 10. С. 280-287.

9. Герилів Д.Ю. Загальнотеоретична характеристика інтегративного підходу до типології держави Науковий вісник Міжнародного гуманітарного університету. Юриспрудениія. 2013. Вип. 6-1 (1). С. 12-15.

10. Khanh N.T.V., Danh M.T., Gim G. E-Government in Vietnam: Situation, Prospects, Trends, and Challenges Open Government: Concepts, Methodologies, Tools, and Applications. 2020. P. 1915-1931.

11. Мєзєнцев А.В. Електронне урядування, електронна демократія - підходи до визначень. Теорія та практика державного управління. 2015. Вип. 1. С. 64-69.

12. Zhenmin L. United Nations E-Goverment Survey 2018. Department of Economic and Social Affairs. Gearing E-Goverment to Support transformation tovards Sunsrainablt and Resilient Esilent societies United Nations. New York, 2018. URL: publicadministration.un.org.

13. United Nations E-Goverment Survey 2018. Department of Economic and Social Affairs. Gearing E-Goverment to Support transformation tovards Sunsrainablt and Resilient Esilent societies United Nations. New York, 2018 .URL: publicadministration.un.org. 
УДК 342.349:005.5

DOI https:// doi.org/10.32850/LB2414-4207.2020.14.09

\title{
ДОКТРИНАЛЬНИЙ ПІДХІД ДО ВИЗНАЧЕННЯ ЕКОЛОГІЧНОЇ ШКОДИ У ЄВРОПЕЙСЬКОМУ СОЮЗІ ТА В УКРАЇНІ
}

\author{
Сірант Мирослава Миколаївна, \\ кандидат юридичних наук, доцент, \\ доцент кафедри конституційного та \\ міжнародного права \\ (Навчально-науковий інститут права, \\ психології та інноваційної освіти \\ Національного університету \\ «Львівська політехніка», \\ м. Львів, Україна)
}

Метою статті $є$ аналіз доктринального підходу до визначення екологічної шкоди у Свропейському Союзі та в Україні. Проаналізовано національне законодавство України та нормативно-правові акти Свропейського Союзу. Розглянуто визначення поняття «екологічна шкода» у дослідженнях українських і європейських вчених. Охарактеризовано такі поняття, як навколишнє природне середовище, природне довкілля, економічна й екологічна шкода, що виникла унаслідок порушення законодавства про захист навколишнього природного середовища. Проаналізовано ключові чинники, які впливають на визначення екологічної та економічної шкоди внаслідок порушення екологічного законодавства. Подано перелік заходів, спрямованих на удосконалення нормативно-правового регулювання відповідальності за екологічні правопорушення відповідно до нормативних актів Європейського Союзу у контексті визначення екологічної шкоди.

Підкреслено, що екологічна шкода безпосередньо посягає на екологічні, а не на майнові інтереси. Шкода навколишньому середовищу поділяється на два види - екологічну й економічну. Екологічна шкода порушує екологічні інтереси суспільства в забезпеченні здорового, сприятливого для життя, продуктивного навколишнього середовища. Матеріальним об'єктом посягання слугує якість навколишнього середовища, стан екологічних систем, ті обмінні процеси, що протікають у біосфері, постійно і незмінно відтворюють життя у всіх формах прояву. У свою чергу, економічна шкода завдається майновим правам та інтересам природокористувачів. Шкода може виражатися в нанесенні майнової шкоди (загибелі, пошкодженні, знищенні матеріальних цінностей) або в неотриманні передбачуваного доходу.

Зроблено висновок про те, що визначення поняття шкоди навколишньому середовищу дається в законодавстві фрагментарно. Різні компоненти або не розкриваються, або описуються через інші терміни, що не сприяє попередженню екологічної шкоди. Доцільно внести більш повні поняття в закон «Про охорону навколишнього природного середовища» для уніфікації законодавчої та правозастосовної діяльності.

Ключові слова: екологія, навколишнє природне середовище, довкілля, європейська інтеграція, екологічна шкода, природні ресурси. 


\title{
DOCTRINAL APPROACH TO DETERMINATION OF ENVIRONMENTAL HARM IN THE EUROPEAN UNION AND UKRAINE
}

\author{
Sirant Myroslava Mykolaivna, \\ Candidate of Juridical Sciences, \\ Associate Professor, \\ Senior Lecturer at the Department of \\ Constitutional and International Law \\ (Institute of Jurisprudence, Psychology \\ and Innovative Education of the Lviv \\ Polytechnic National University, \\ Lviv, Ukraine)
}

The aim of the article is to analyze the doctrinal approach to determining environmental damage in the European Union and Ukraine. The national legislation of Ukraine and normative legal acts of the European Union are analyzed. The definition of "environmental damage" in the research of Ukrainian and European scientists is considered. The concepts of environment, natural environment, economic and ecological damage caused by violation of the legislation on environmental protection are described. The key factors influencing the definition of environmental and economic damage as a result of violation of environmental legislation are analyzed. Measures aimed at improving the legal regulation of liability for environmental offenses are in line with EU regulations in the context of environmental damage.

It is emphasized that environmental damage directly affects environmental rather than property interests. Damage to the environment is divided into two types - environmental and economic. Environmental damage violates the environmental interests of society in ensuring a healthy, life-friendly, productiveenvironment. The material object of encroachment is the quality of the environment, the state of ecological systems, those metabolic processes that take place in the biosphere, which constantly and invariably reproduce life in all its forms. In turn, economic damage is inflicted on property rights and interests of nature users. Damage can be expressed in causing property damage (death, damage, destruction of property) or in not receiving the estimated income.

It is concluded that the definition of environmental damage is given in the legislation in fragments. The various components are either not disclosed or are described in other terms, which does not help prevent environmental damage. It is advisable to introduce more complete concepts in the law "On Environmental Protection" to unify legislative and law enforcement activities.

Key words: ecology, environment, environment, European integration, environmental damage, natural resources.

Постановка проблеми. Зміни у соціально-економічній і політичній системі України, пов'язані з науково-технічним прогресом і зростанням виробництва, окупацією частини території країни, призвели до збільшення негативного впливу антропогенних чинників на екологічні системи держави. Водночас проведення реформ, пов'язаних з інтеграцією України ув європейський соціально-економічний простір, значно підвищили роль права як регулятора суспільних відносин. Включення в обіг землі та природних ресурсів визначає актуальність вивчення ролі, функцій і можливостей правового механізму у сфері охорони навколишнього природного середовища, відшкодування екологічної шкоди. Дослідження правового феномена «екологічна шкода» необхідне для підвищення ефективності правового регулювання в контексті 
адаптації національного екологічного законодавства до вимог Європейського Союзу та впровадження у юридичну практику нормативних актів, прийнятих на виконання директив Європейського Союзу.

Метою статті є дослідження доктринального підходу до визначення екологічної шкоди в Свропейському Союзі та в Україні.

Стан дослідження проблеми. Окремі питання визначення поняття екологічної шкоди досліджено у працях науковців: В.І. Андрейцева, Г.І. Балюк, Н.В. Дегтярь, Л.Д. Загвойської, О.С. Колбасова, М.І. Краснова, М.В. Краснової, Н.Р. Малишевої, Н.В. Олійник, І.М. Сотник, І.П. Солов'я, М.Р. Цибульникової, Ю.С. Шемшученка та ін. Однак реалізація Угоди про асоціацію між Україною, з однієї сторони, та Свропейським Союзом, Свропейським співтовариством з атомної енергії і їхніми державами-членами, з іншої сторони, ставить питання, які стосуються оптимізації національного законодавства у сфері екології, що вимагає проведення теоретико-правових досліджень.

Виклад основного матеріалу. Реформування в Україні охоплює одночасно всі сфери життєдіяльності суспільства (економічну, політичну, соціальну, екологічну та культурно-духовну). Послідовне та системне реформування зіштовхнулося з низкою проблем. Зокрема, коли йдеться про діяльність органів державної влади, не завжди приділяється належна увага питанням екології [1, с. 6002]. Екологічне законодавство України та Європейського Союзу орієнтоване на забезпечення та підтримання сприятливого стану навколишнього середовища, однак у процесі розвитку людства природа як основа життєдіяльності піддається різноманітному негативному впливу.

У законодавстві України використовуються терміни «навколишнє середовище» та «природне середовище». Відповідно до Закону «Про охорону навколишнього природного середовища» сукупність компонентів природного середовища, природних i природно-антропогенних об'єктів, антропогенних об'єктів розглядаються як навколишнє природне середовище, поняття «природне середовище», враховуючи норми Закону «Про оцінку впливу на довкілля» охоплює ті самі елементи, за винятком антропогенних об'єктів [2; 3].

Можна констатувати, що навколишнє середовище - це природне середовище й антропогенні об'єкти. Виходячи з легального визначення як елемента навколишнього середовища, можна визнати будь-який об'єкт - воду, ліс, атмосферне повітря. Однак у ст. 5 Закону «Про охорону навколишнього природного середовища» антропогенні об'єкти не вказані 3-поміж об'єктів охорони навколишнього середовища [2].

На думку вчених, включення законодавцем до змісту поняття навколишнього середовища антропогенних об'єктів поряд з іншими компонентами навколишнього середовища може привести до необгрунтованої інтервенції в інші галузі законодавства.

Антропогенний об'єкт - це об'єкт, створений людиною для забезпечення соціальних потреб, що не володіє властивостями природних об'єктів. Правові відносини, які виникають у зв'язку з такими об'єктами, включаючи охорону, регулюються різними галузями права, передусім адміністративним і цивільним законодавством.

На законодавчому рівні довкілля трактується як сукупність природних і природно-антропогенних ресурсів, що впливають на існування та розвиток людства, включаючи атмосферу, воду, моря, землі, корисні копалини, ліси, пасовища, водно-болотні угіддя, дику флору та фауну, об'єкти природно-культурної спадщини, природні території, що охороняються, зони розташування пам'яток, сільське та міське середовище.

У літературі акцентується увага на низці аспектів легального визначення. Навколишнє середовище - це природні ресурси, які впливають на розвиток та існування 
людини. Це поняття не поширюється на соціальні, економічні та інші чинники. Ці природні ресурси включають природно-антропогенні об'єкти. Як елемент навколишнього середовища можуть розглядатися тільки ті об'єкти, які тісно пов' язані з природою.

У законодавстві довкілля розглядається як сукупність природних і природно-антропогенних об'єктів, однак антропогенні об'єкти не визнаються складовою частиною навколишнього середовища.

Для правового регулювання відносин у сфері охорони навколишнього середовища та природокористування визначення екологічної шкоди має ключове значення. Традиційно в юридичній літературі, передусім у цивілістичних дослідженнях, поняття шкоди та збитків розглядалися як близькі та взаємопов'язані. Нині більшість правознавців розглядає шкоду як майнову. Такий підхід характерний для законодавства.

Коли говорять про екологічну шкоду, то йдеться про заподіяння шкоди безпосередньо природі. Необхідно зазначити, що господарська діяльність людини пов' язана з несприятливим впливом на природне середовище, яке розуміється як комплекс екологічних систем. За наявності відповідного дозволу заподіяна природі шкода може бути визнана правомірною, у зв'язку з цим така шкода не розглядається. Досліджується тільки неправомірна шкода, що є результатом порушення вимог охорони навколишнього природного середовища або використання природних ресурсів. В екологічному законодавстві використовується поняття «шкода навколишньому середовищу» (ст. 69 Закону «Про охорону навколишнього природного середовища»), проте в теорії екологічного права значно поширилося поняття «екологічна шкода».

О.О. Веклич розглядає як екологічну шкоду будь-яке погіршення стану навколишнього середовища, що відбулося внаслідок порушення правових екологічних вимог [4]. Така шкода проявляється у формі забруднення навколишнього середовища, псування, знищення, пошкодження, виснаження природних ресурсів, руйнування екологічних систем, яке може спричинити заподіяння шкоди здоров'ю та майну.

На нашу думку, екологічна шкода безпосередньо посягає на екологічні, а не на майнові інтереси. Шкода навколишньому середовищу поділяється на два види - екологічну й економічну. Екологічна шкода порушує екологічні інтереси суспільства в забезпеченні здорового, сприятливого для життя, продуктивного навколишнього середовища. Матеріальним об'єктом посягання слугує якість навколишнього середовища, стан екологічних систем, ті обмінні процеси, які протікають у біосфері, постійно і незмінно відтворюють життя у всіх формах прояву. У свою чергу, економічна шкода завдається майновим правам та інтересам природокористувачів. Шкода може виражатися в нанесенні майнової шкоди (загибелі, пошкодженні, знищенні матеріальних цінностей) або в неотриманні передбачуваного доходу.

Поряд 3 цим M.I. Хилько виділяв шкоду навколишньому середовищу первинного та вторинного походження [5, с. 13]. Шкода первинного походження - кількісні та якісні втрати в навколишньому середовищі, які проявляються в забрудненні: у фізико-хімічній зміні складу повітря, води, земель, що створює загрозу для здоров'я населення, рослинного та тваринного світу, у псуванні, пошкодженні природних об'єктів та екосистем. Змінена внаслідок завданої шкоди якість природного середовища негативно впливає на соціальне середовище, завдається шкода здоров'ю людей, матеріальним цінностям.

Шкода навколишньому середовищу вторинного походження розуміється у двох значеннях: екологічна (виражена у вигляді пошкодження або знищення природного об'єкта) й екогенна (знищення або пошкодження майна, що не має ознак природного об'єкта), розрізняються за об'єктом протиправного посягання. У доктринах ЄС використовуються поняття «екологічна шкода» та «шкода природним ресурсам» [6, с. 14]. 
Учені у країнах ЄС зазначають, що безпосереднім об'єктом посягання є природа, однак не всі з них пов'язують екологічну шкоду та порушення еколого-правових вимог. Існує науковий підхід, де екологічну шкоду розглядають як негативні зміни та винятковий вплив. Але оцінка того, що є позитивними або негативними змінами, $\epsilon$ суб'єктивною та невизначеною, оскільки навіть істотні зміни, будучи деструктивними на перший погляд, не обов' язково у підсумку виявляться такими.

М.В. Краснова, досліджуючи методи підрахунку шкоди, заподіяної навколишньому природному середовищу, та їхні правові засади, як екологічну шкоду розглядає чисту шкоду, заподіяну природним ресурсам, які не мають власників; шкоду, не пов' язану із заподіянням шкоди особі або майну; шкоду, що заподіюється природним ресурсам, які знаходяться у власності фізичних або юридичних осіб, що перевищує ринкову вартість таких ресурсів [7, с. 67-68]. Учена акцентує увагу на тому, що ринкова вартість пошкоджених природних ресурсів має відшкодовуватися за допомогою застосування цивільно-правових норм, а екологічна цінність пошкоджених природних ресурсів - регулюватися екологічним правом.

Екологічна шкода спричиняє шкоду неекологічного характеру 4 зв'язку 3 тим, що більшість природних об'єктів мають власників і користувачів і $є$ засобом вилучення певних матеріальних благ, однак зниження економічної цінності природних ресурсів внаслідок вчинення екологічного правопорушення за суттю відрізняється від традиційного поняття економічної шкоди. Якщо розділяти економічну й екологічну цінність природних об'єктів, то на практиці особа, котра застосовує право, може зосередитися на охороні економічної цінності, ігноруючи екологічну складову частину. Такий підхід може призвести до зменшення екологічної цінності природних ресурсів щодо збільшення ринкової вартості. Виходячи із зазначених підходів, не ясно, чи потрібно відносити до екологічної шкоди збиток, заподіяний природним об'єктам, що перебувають під загрозою зникнення, рослинам і тваринам, які не мають ринкової вартості у зв'язку з виключенням із господарського обороту, але становлять економічну й екологічну цінність. Екологічна цінність таких природних ресурсів може охоронятися за допомогою екологічного права, а їхня економічна цінність, яка не виражається в ринковій вартості, не регулюється ні екологічним, ні цивільним правом. Такий підхід дозволяє відносити до екологічної шкоди шкоду, заподіяну таким природним ресурсам, як, наприклад, атмосферне повітря, право власності на яке неможливо індивідуалізувати.

На нашу думку, немає сенсу розділяти екологічну й економічну цінність природних ресурсів, оскільки згідно з Конституцією України природні ресурси належать Українському народу, державі. Відповідно, пошкодження природних ресурсів заподіює шкоду економічним і екологічним інтересам одного суб'єкта - держави, уповноважені державні органи можуть подавати позов 3 метою відшкодування збитків економічним і екологічним інтересам, що має значення для охорони природи.

У країнах Європейського Союзу чимало вчених використовують поняття «шкода навколишньому середовищу», розуміючи під ним шкоду, заподіяну безпосередньо природі [8]. Вчені відносять до неї: забруднення або пошкодження екологічних ресурсів певної території, посягання на екологічні інтереси природних об'єктів, яке спричинило негативну зміну структури або функції екосистеми, проявляється у зниженні якості навколишнього середовища території та деградації екологічної системи. На нашу думку, для визначення шкоди, об'єктом якої є природа, краще застосовувати поняття «екологічна шкода».

Деякі правознавці використовують поняття «посягання на права внаслідок забруднення навколишнього середовища» та «пошкодження навколишнього середовища» 
для позначення шкоди, об'єктом посягання якого $є$ не тільки природа, а й майно та здоров'я людини, пошкоджені внаслідок забруднення навколишнього середовища. Якщо одночасно використовувати ці поняття, то може виникнути плутанина. Поняття «навколишнє середовище», що виражає антропоцентризм, розуміється як навколишня природа людини, а поняття «екологія», що є вираженням екоцентризму, як система взаємопов'язаних елементів природи, є умовою життя людини як одного із живих організмів.

У праві є відмінності у трактуванні поняття «шкода навколишньому середовищу». У Законі «Про охорону навколишнього природного середовища» шкода визначається як заподіяна внаслідок порушення законодавства про охорону навколишнього природного середовища (ст. 69) [2]. У Законі «Про оцінку впливу на довкілля» запобігання шкоди довкіллю передбачає забезпечення екологічної безпеки, охорони довкілля, раціонального використання та відтворення природних ресурсів у процесі прийняття рішень про провадження господарської діяльності, яка може мати значний вплив на довкілля, з урахуванням державних, громадських і приватних інтересів [3].

Як бачимо, екологічна шкода зводиться законодавцем тільки до однієї форми. На це зверталася увага у юридичній літературі. Зокрема, зазначається, що зведення шкоди тільки до охорони навколишнього середовища звужує зміст цього поняття. На нашу думку, шкода навколишньому середовищу може бути заподіяна внаслідок забруднення, виснаження, псування, знищення, нераціонального використання природних ресурсів, деградації та руйнування природних екологічних систем, природних комплексів і природних ландшафтів, іншого порушення законодавства в галузі охорони довкілля. Поняття шкоди навколишнього середовища, подане у ст. 69 «Про охорону навколишнього природного середовища», вимагає уточнення. Для з' ясування змісту цього поняття доцільно дослідити елементи - негативні зміни, деградацію природних екологічних систем і виснаження природних ресурсів. Стосовно земельних ресурсів виділяються такі види негативних змін: забруднення, захаращення, деградація, порушення, підтоплення, затоплення, перезволоження, заболочування, ерозія, опустелювання (англ. desertification), забруднення земель важкими металами, радіонуклідами, нафтою та нафтопродуктами, іншими токсичними речовинами, захаращення відходами виробництва та споживання, вирубок і згарищ на землях лісового фонду, утворення ярів, зсувів, селевих потоків, карстових процесів.

Що стосується деградації природних екологічних систем, то це поняття визначається як зміна структури екосистем, природної продуктивності, обмінних властивостей грунтів, зникнення видів тварин і рослин, порушення біологічних циклів тварин і рослин. Стійкі негативні зміни у стані природних екологічних систем визнаються зонами надзвичайної екологічної ситуації. Поняття виснаження природних ресурсів у законодавстві практично не використовується.

Можна дійти висновку, що визначення поняття шкоди навколишньому середовищу дається в законодавстві фрагментарно. Різні компоненти або не розкриваються, або описуються через інші терміни, а це не сприяє попередженню екологічної шкоди. Доцільно внести більш повні поняття у Закон «Про охорону навколишнього природного середовища» для уніфікації законодавчої та правозастосовної діяльності.

На підставі аналізу Директиви 2004/35/СС Європейського Парламенту та Ради «Про екологічну відповідальність за попередження та ліквідацію наслідків завданої навколишньому середовищу шкоди» можна зробити висновок, що на нормативному рівні визнається публічний характер екологічної шкоди [9]. Громадяни повинні вживати заходів з охорони природи, зберігати окремо побутові відходи для зменшення шкоди навколишньому середовищу в повсякденному житті згідно з вимогами зако- 
нодавства в галузі охорони навколишнього середовища. У зв'язку із забрудненням навколишнього середовища, руйнуванням екологічного стану та діями, що завдають шкоди суспільним інтересам, можуть подаватися позови до народного суду, громадських об'єднань.

В Аналітичному документі «Екологічна відповідальність: досвід $С С$ та можливості для України» вказується, що впровадження механізму екологічної відповідальності, передбаченого Директивою 2004/35/СС, в Україні потребуватиме вирішення низки питань правового, інституційного та організаційного характеру, а саме:

- встановлення у національному законодавстві України концептуальних засад екологічної відповідальності, передбачених Директивою 2004/35/ СС, і визначення поняття «екологічна шкода». Зокрема, визначення обсягу екологічної шкоди на основі аналізу еквівалентних ресурсів і вартості заходів, необхідних для відновлення природних ресурсів до вихідного стану;

- визначення виду нормативно-правового акта, яким впроваджуватиметься екологічна відповідальність за екологічну шкоду, передбачена Директивою 2004/35/СС. Встановлення правового механізму екологічної відповідальності за попередження та ліквідацію наслідків шкоди, завданої довкіллю, на рівні закону, а на рівні підзаконних нормативно-правових актів конкретизація положення закону технічного характеру;

- встановлення компетентного органу, відповідального за впровадження механізму екологічної відповідальності, передбаченого Директивою 2004/35/ЄС, посилення спроможності й інституційного розвитку ключових суб'єктів впровадження механізму екологічної відповідальності, передбаченого Директивою 2004/35/СС [6, с. 5].

Виходячи з проведеного аналізу, можна дійти висновку, що у законодавстві екологічна шкода розглядається як різновид шкоди навколишньому середовищу. У межах останньої виділяють екологічну шкоду, об'єктом посягання якої є природа, й екогенну шкоду, що складається в порушенні права на охорону здоров'я людини та майнових інтересів внаслідок заподіяння шкоди природі.

У законодавстві відсутнє широке трактування поняття забруднення навколишнього середовища, воно розкривається лише через окремі компоненти природи. Оскільки у праві ЄС та України існує певна відмінність в розумінні цього поняття, для зручності порівняльного аналізу воно буде використовуватися в такому значенні, як погіршення стану навколишнього середовища, що відбулося внаслідок порушення еколого-правових вимог, за якого об'єктом безпосереднього протиправного посягання виступають природні об'єкти, опосередкованого впливу на здоров'я людини, яке зазвичай ушкоджується внаслідок заподіяння шкоди природним ресурсам, що $є$ основою життя людини.

Основною тезою Конференції Організації Об'єднаних Націй із навколишнього середовища та розвитку (Ріо-де-Жанейро, 1992 р.) стала теза «Здоров'я людей залежить від здоров'я довкілля» [10].

Аналіз легального підходу до визначення поняття «навколишнє середовище» в Україні та Європейському Союзі свідчить про те, що це поняття включає природні та природно-антропогенні об'єкти, а в Свропейському Союзі поширюється на антропогенні об'єкти. Поняття «екологічна шкода» застосовується в Україні тільки у правовій доктрині й акті стратегічного планування (Основні засади (стратегію) державної екологічної політики України на період до 2030 р.) [11; 12, с. 54]. В інших випадках законодавець використовує інший термін - «шкода навколишньому середовищу».

Висновки. В Україні на рівні законодавства закріплюється визначення поняття шкоди навколишньому середовищу, проте трактується дуже вузько тільки як порушення законодавства про охорону навколишнього природного середовища. Водно- 
час при визначенні обов' язку, пов' язаного з відшкодуванням шкоди, перераховуються й інші форми заподіяння шкоди навколишньому середовищу (ч. 2 та 3 ст. 69 Закону «Про охорону навколишнього природного середовища»).

Загальною проблемою для України і Свропейського Союзу є те, що визначення поняття «шкода навколишньому середовищу» (в Україні) або «екологічна шкода» (в СС) є фрагментарним. Різні компоненти та складники або не розкриваються, або описуються через інші терміни, що навряд чи може сприяти координації законодавчих заходів, спрямованих на попередження екологічної шкоди, яка проявляється в різних формах. У зв'язку з цим доцільно закріпити легальне визначення поняття екологічної шкоди в Законі «Про охорону навколишнього природного середовища» та дати більш широке трактування шкоди навколишньому природному середовищу. Стосовно доктринальних підходів до поняття «екологічна шкода», то схожість полягає в тому, що безпосереднім об'єктом посягання визнається природа, а опосередкованим - здоров'я людини.

Натомість у національній доктрині існує певна єдність, оскільки будь-яке погіршення навколишнього середовища розглядається як екологічна шкода. На нашу думку, поняття шкоди навколишньому природному середовищу в законодавстві необхідно сформулювати як будь-яке погіршення стану навколишнього середовища, що відбулося внаслідок порушення еколого-правових вимог, яке спричинило деградацію природних екологічних систем і (або) виснаження природних ресурсів, і (або) здійснило негативний вплив на стан здоров' я людини. Це приводить до необхідності в законодавстві при визначенні поняття шкоди навколишньому природному середовищу враховувати опосередкований негативний вплив на здоров' я людини.

\section{Список використаних джерел:}

1. Ковалів М., Ссімов С., Крамар Р., Скриньковський Р. Перспективи реформування організаційно-правового механізму забезпечення прав і свобод людини та громадянина. Traektoriâ Nauki = Path of Science. 2017. Vol. 3. №. 10. S. 6001-6008.

2. Про охорону навколишнього природного середовища : Закон України від 25 червня 1991 р. № 1264-ХІІ. Відомості Верховної Ради України. 1991. № 41. Ст. 546.

3. Про оцінку впливу на довкілля : Закон України від 23 травня 2017 р. № 2059-VIII. Відомості Верховної Ради Украӥни. 2017. № 29. Ст. 315.

4. Веклич О.О. Базові інноваційні підходи до формування компенсаційного механізму відшкодування збитків від погіршення/знищення екосистемних послуг. Електронне наукове фрахове видання «Ефективна економіка». 2019. № 5. URL: http:/ / www.economy.nayka.com.ua/pdf/5_2019/3.pdf.

5. Хилько М.І. Екологічна безпека України : навчальний посібник. Київ, 2017. 267 с.

6. Екологічна відповідальність: досвід ЄС та можливості для України. Аналітичний документ. Київ : Ресурсно-аналітичний центр «Суспільство і довкілля» 2018. URL: https:/ / www.civic-synergy.org.ua/wp-content/uploads/2018/04/webenvironmentalliabilityua2018.pdf.

7. Краснова М.В. Методи підрахунку шкоди, заподіяної навколишньому природному середовищу, та їх правові засад. Юридичний вісник. Повітряне і космічне право. 2008. № 2. С. 66-70.

8. Микієвич М.М., Андрусевич Н.І., Будякова Т.О. Європейське право навколишнього середовища : навчальний посібник. Львів, 2004. 256 с.

9. Директива 2004/35/ЄС Свропейського Парламенту та Ради «Про екологічну відповідальність за попередження та ліквідацію наслідків завданої навколишньому середовищу шкоди». Законодавство України. URL: https://zakon.rada.gov.ua/laws/ show/994_965\#Text. 
10. Рио-де-Жанейрская декларация по окружающей среде и развитию. Принята Конференцией ООН по окружающей среде и развитию, Рио-де-Жанейро, 3-14 июня 1992 г. Законодавство України.URL: https://zakon.rada.gov.ua/laws/show/995_455\#Text.

11. Про основні засади (стратегії) державної екологічної політики України на період до 2030 р. : Закон України від 28 лютого 2019 р. № 2697-VIII. Відомості Верховної Ради Украӥни. 2019. № 16. Ст. 70.

12. Правова доктрина України : у 5 т. Т. 4: Доктринальні проблеми екологічного, аграрного та господарського права. Харків : Право, 2013. 848 с. 
УДК $340.113+340.134$

DOI https:// doi.org/10.32850/LB2414-4207.2020.14.10

\title{
ГАРАНТІЇ ВЗАЕМОДІЇ ЗАКОНОТВОРЧОСТІ ТА ПОЛІТИЧНОГО ПЛЮРАЛІЗМУ В УКРАЇНІ: ТЕОРЕТИКО-ПРАВОВИЙ І ПРАКТИЧНИЙ ВИМІРИ
}

\author{
Шапран Юлія Володимирівна, \\ аспірантка кафедри теорії права та \\ держави юридичного факультету \\ (Київський національний університет \\ імені Тараса Шевченка, \\ м. Київ, Україна)
}

У роботі автором обгрунтовано високий рівень наукової та практичної витребуваності дослідження теоретико-правових і практичних аспектів гарантій взаємодії законотворчості та політичного плюралізму в Україні. На підставі аналізу вітчизняної практики взаємодії законотворчості та політичного плюралізму узагальнено й охарактеризовано гарантії взаємодії законотворчості та політичного плюралізму в Україні.

Встановлено, що сьогодні стан дослідження питань гарантій взаємодії законотворчості та політичного плюралізму в Україні як теоретико-правової та практичної проблематики, а також шляхів їх посилення відзначається: по-перше, надмірною насиченістю досліджень політико-правових аспектів політичного плюралізму, що представлено переважно працями вчених - представників політичних наук; по-друге, епізодичністю та традиційністю наукових досліджень законотворчості як явища позаполітичного плану, що $\epsilon$ засобом соціальних трансформацій у суспільстві, будучи забезпеченою та гарантованою державою; по-третє, дефіцитом саме сучасних конщептуальних уявлень про гарантії взаємодії законотворчості та політичного плюралізму, які дозволили б:

а) сформувати єдині цілісні й обгрунтовані підходи до побудови оптимальної та суспільно витребуваної моделі їх взаємодії;

б) максимально реалізувати їх функціональний потенціал за сучасних умов розбудови політичної системи, діяльності системи суб'єктів, котрі здійснюють законотворчість або впливають на ії здійснення, удосконалення системи вітчизняного законодавства.

Підсумовано, що до гарантій взаємодії законотворчості та політичного плюралізму належать: чітко визначене коло суб'єктів, наділених правом законодавчої ініціативи, наявність двопалатного парламенту, закріплення недоторканності парламентарів, особливий процесуальний порядок внесення і розгляду законопроектів, а також голосування за них, законодавче закріплення права народу брати участь у законотворчості та наявність ефективно функціонуючого механізму ії здійснення; визнання коаліції та опозиції як самостійних суб'єктів парламентських процесів, у т. ч. і щодо розгляду, обговорення та прийняття законодавчих актів тощо. Вказані гарантії є основою здійснення законотворчості та функціонування політичного плюралізму як явищ самостійних, водночас таких, що можуть існувати й ефективно функціонувати виключно на засадах взаємодії.

Ключові слова: правоутворення, законотворчість, правотворча політика, політичний плюралізм, гарантії взаємодії законотворчості та політичного плюралізму. 


\title{
GUARANTEES OF INTERACTION OF LEGISLATION AND POLITICAL PLURALISM IN UKRAINE: THEORETICAL, LEGAL AND PRACTICAL DIMENSION
}

\author{
Shapran Yuliia Volodymyrivna, \\ Graduate Student at the Department \\ of Theory of Law and States \\ of the Faculty of Law \\ (Taras Shevchenko National \\ University of Kyiv, \\ Kyiv, Ukraine)
}

The author substantiates the high level of scientific and practical demand for the study of theoretical, legal and practical aspects of guarantees of the interaction of lawmaking and political pluralism in Ukraine. On the basis of the analysis of domestic practice of interaction of law-making and political pluralism guarantees of interaction of law-making and political pluralism in Ukraine are generalized and characterized.

It is established that today the state of research on the issues of guarantees of interaction between lawmaking and political pluralism in Ukraine, as theoretical, legal and practical issues, as well as ways to strengthen them is as follows: first, excessive saturation of research on political and legal aspects of political pluralism. represented mainly by the works of scientists - representatives of political science; secondly, the episodic and traditional scientific research of law-making as a phenomenon of non-political plan, which is a means of social transformation in society, being provided and guaranteed by the state; thirdly, the lack of modern conceptual ideas about the guarantees of the interaction of lawmaking and political pluralism, which would allow:

a) to form unified holistic and reasonable approaches to the construction of optimal and socially demanded model of their interaction;

b) to maximize their functional potential in the current conditions of development of the political system, the activities of the system of entities that carry out lawmaking or influence its implementation, the improvement of the domestic legislation.

Itisconcluded that the guarantees ofinteraction betweenlaw-makingand political pluralism include: a clearly defined range of subjects endowed with the right of legislative initiative, the presence of a bicameral parliament, consolidating the immunity of parliamentarians, special procedural order of discussion, consideration of bills and voting for them. in lawmaking and the existence of an effectively functioning mechanism for its implementation; recognition of the coalition and the opposition as independent subjects of parliamentary processes, including the consideration, discussion and adoption of legislation, etc. These guarantees are the basis for the implementation of lawmaking and the functioning of political pluralism as independent phenomena, while those that can exist and function effectively solely on the basis of interaction.

Key words: law-formation, law-making, law-making policy, political pluralism, guarantees of interaction of legislation and political pluralism.

Вступ. Важливим напрямом будь-якого наукового дослідження є практичний, у т. ч. і той, що стосується вивчення гарантій взаємодії законотворчості та політичного плюралізму в Україні, їх критичного аналізу та встановлення недоліків функціонування, а також виокремлення й обгрунтування окремих шляхів посилення їх взаємодії. Аналіз зазначених аспектів взаємодії законотворчості та політичного плюралізму має важливе значення, що зумовлено як станом їх наукової розробки, так і практичними аспектами взаємодії законотворчості та політичного плюралізму в Україні. 
Актуалізує витребуваність наукових досліджень гарантій взаємодії законотворчості та політичного плюралізму в Україні ще й те, що сьогодні у практичному плані склалася ситуація, коли законотворчість і політичний плюралізм розвиваються і функціонують відірвано одне від одного. Сьогодні дедалі частіше виникають в Україні ситуації, коли хаотичний, неусталений політичний плюралізм, що розвивається за умов низького рівня політичної та правової культури вітчизняного суспільства, призводить до виникнення політичної неузгодженості у прийнятті тих або інших законодавчих рішень (наприклад, це ті випадки, коли не вистачало голосів парламентарів для прийняття суспільно важливих рішень, що призводило до неодноразових переголосувань за законопроект у разі його неприйняття, запровадження у практику роботи Верховної Ради України такого «позаправового» інституту, як сигнальне голосування під час пленарних засідань тощо). Те саме можливо сказати і щодо законотворчості, яка може не лише сприяти розвитку політичного плюралізму та його посиленню, але і використовуватися у різноманітних суб'єктивних, навіть антисоціальних інтересах, гальмуючи функціонування або взагалі ігноруючи засади політичного плюралізму, реалізуючи ті або інші політичні амбіції (наприклад, зміна виборчого законодавства перед початком виборчої компанії в державі з метою створення штучних переваг або перепон для тієї або іншої політичної сили чи посадових осіб, що відбувалося у 2004, 2005, 2011 рр. шляхом прийняття таких законодавчих актів, як: Закон України «Про вибори народних депутатів» № 1665-IV від 25 березня 2004 р.; Закон України «Про внесення змін до Закону України «Про вибори народних депутатів України» № 2777-IV від 07 липня 2005 р.; Закон України «Про вибори народних депутатів України» № 4061-VI від 17 листопада 2011 р. [1-3]. До цього переліку законодавчих актів також можна віднести і прийняття Виборчого кодексу України [4], який фактично запроваджує пропорційну систему виборів народних депутатів України, водночас зумовлює недоцільність для політичних сил або окремих народних депутатів, представлених сьогодні у Верховній Раді України, проводити активну політичну компанію на місцях, яка раніше здійснювалася з метою забезпечення прихильності електорату на мажоритарних виборчих округах.

Мета статті. 3 урахуванням вказаного вище, відзначаючи високий рівень наукової та практичної витребуваності дослідження теоретико-правових і практичних аспектів гарантій взаємодії законотворчості та політичного плюралізму в Україні, вважаємо за доцільне в цій наукові роботі: на підставі аналізу вітчизняної практики взаємодії законотворчості та політичного плюралізму узагальнити й охарактеризувати гарантії взаємодії законотворчості та політичного плюралізму в Україні.

Основна частина. Продовжуючи наше дослідження відповідно до поставлених завдань, насамперед вважаємо за доцільне здійснити аналіз вітчизняної практики взаємодії законотворчості та політичного плюралізму, що дозволить визначити та надати характеристику гарантіям їх взаємодії. Відзначимо, що в юридичній літературі характеристика вітчизняної практики взаємодії законотворчості та політичного плюралізму розкрита епізодично, представлена непослідовно та відображає переважно ситуативні проблеми, які стосуються практики законотворчості або розвитку політичного плюралізму, окремим аспектом яких є їх взаємодія. 3 огляду на це вважаємо за доцільне не лише провести аналіз поглядів вчених, які стосуються практики взаємодії законотворчості та політичного плюралізму в Україні, але і проаналізувати аналіз практичних ситуацій такої взаємодії, що відбувається у вітчизняній практиці законотворення за умов становлення та розвитку політичного плюралізму.

Насамперед звернемо увагу на те, що в юридичній літературі, характеризуючи особливості сучасного стану законотворчості, вченими цілком справедливо звертається 
увага на наявність непоодиноких прикладів відірваності законотворчості від реалій суспільно-політичного життя або надмірної політичної заангажованості процесу законотворчості (чи правотворчості в цілому), що виявляється у:

- зловживанні правом на законодавчу ініціативу;

- можливості внесення необмеженої кількості поправок і пропозицій до законопроектів;

- підготовки та внесення альтернативних законопроектів;

- лобіюванні тих або інших політичних інтересів у змісті законодавчих актів;

- необгрунтованому блокуванні прийняття суспільно витребуваних законодавчих рішень.

Також цілком справедливо вченими акцентується увага на факті відставання законотворчості в Україні від сучасного суспільного життя, невмінні законодавця відтворити в нормах права всіх можливих ситуацій, які потребують правового регулювання, недосконалого використання засобів і способів юридичної техніки [5, с. 25-26] тощо. У цьому плані варто погодитися із думкою вченої, оскільки політичний плюралізм як стан вільного волевиявлення суб'єктів політичної системи у процесі законотворчості не повинен бути використаний виключно з метою реалізації тих або інших суб'єктивних інтересів, особливо тих інтересів, які є суспільно шкідливими. Досить резонансним прикладом у цьому плані виглядають тривалі зміни режиму бюджетного відшкодування податку на додану вартість сільгоспвиробникам в Україні. Фактично при обговоренні й ухваленні законів України про Державний бюджет на відповідний рік і законів України, які стосуються змін до положень податкового законодавства України в частині відшкодування податку на додану вартість [6; 7] зі сторони різноманітних політичних сил, представлених у парламенті, великих вітчизняних агрохолдінгів та інших зацікавлених суб'єктів, відбувається тиск щодо схвалення відповідних положень, якими б закріплювалися гарантії щодо повернення грошових коштів, сплачених як оплата податку на додану вартість при експортних операціях агропродукції. Фактично вказаний приклад доводить, що загальний підхід щодо законодавчого впорядкування умов і порядку повернення податку на додану вартість вітчизняним експортерам не є остаточно сформований та усталений, він змінюється залежно від політичної ситуації в країні, рівня тиску з боку зацікавлених суб'єктів тощо. Фактично умови політичного плюралізму, які сьогодні створені при формуванні та функціонуванні Верховної Ради України, є не стільки фактором, який би сприяв забезпеченню рівних умов для ведення господарської діяльності всім суб'єктам господарювання, в т. ч. й у сфері оподаткування, скільки виступає засобом для реалізації різноманітних політичних домовленостей, спричинення політичного тиску з метою лобіювання («просування») відповідних законодавчих рішень.

У цьому плані варто також погодитися з думкою і інших вчених, які відзначаються факт того, що сучасне законотворення в Україні відбувається за умов суттєвого посилення впливу на нього різноманітних політичних чинників, зокрема таких як: поширення політичного протистояння всередині політичних партій і рухів, інтенсивний розпад старих і формування нових суспільних інститутів [8, с. 133]; трансформація політичної системи (в т. ч. і політичної системи України. - Ю. Ш.) в бік посилення ії плюралізації, забезпечення вільного розвитку інституцій і механізмів реалізації політичних інтересів, а це зумовлює зміни самого механізму правотворчості [9, с. 7]; суттєве посилення ролі та значення інституту лобіювання інтересів, що $є$ механізмом впливу певних соціальних груп і об'єднань на процес законотворення [10, с. 515] тощо.

Досить цікавим є приклад законотворчості в частині законодавчого забезпечення державної мовної політики в Україні, що супроводжувалося грунтовними політич- 
ними дискусіями, політичними протистояннями як внутрішнього, так і міждержавного характеру. У 1989 р. Верховною Радою УРСР був прийнятий Закон УРСР «Про мови в УРСР» [11], положеннями якого закріплювався статус української мови як державної, регламентувалися питання розвитку і використання мов інших національностей у республіці; визначалося коло мов міжнаціонального спілкування; закріплювалося право громадян користуватися будь-якою мовою; визначався механізм захисту мов; визначалася мова актів органів державної влади й управління, мова роботи, діловодства і документації тощо. Прийняття вказаного закону супроводжувалося суттєвим загостренням протистоянь між різними політичними силами, представленими у складі тогочасної Верховної Ради УРСР, суттєвий вплив чинився зі сторони суб'єктів, відповідальних за ідеологічний напрям роботи в УРСР. Надалі в Україні було ратифіковано Свропейську хартію регіональних мов або мов меншин 1992 р. [12], проте Закон України про ії ратифікацію втратив чинність як такий, що не відповідає Конституції України (є неконституційним) [13]. У 1996 р. у ст. 10 Конституції України було закріплено, що, державною мовою в Україні є українська; держава забезпечує всебічний розвиток і функціонування української мови в усіх сферах суспільного життя на всій території України та сприяє вивченню мов міжнародного спілкування. В Україні гарантується вільний розвиток, використання і захист російської, інших мов національних меншин України [14].

У 2003 р. Свропейська хартія регіональних мов або мов меншин (1992 р.) була ще раз ратифікована [15]. Протягом 2003-2012 рр. відбувалися підготовка та тривале обговорення в політичних колах нового законодавчого акта, який би стосувався не лише державної мови, а й регламентував би відносини у сфері державної мовної політики. Результатом протистояння між тогочасною політичною коаліцією та опозицією, сформованою в парламенті, було прийняття Закону України «Про засади державної мовної політики» від 03 липня 2012 р. № 5029-VI щодо вживання державної та регіональних мов [16]. Незважаючи на те, що його підготовка та прийняття засновувалися на засадах політичного плюралізму, основною метою було не стільки впорядкувати відносини у сфері державної мовної політики, скільки суттєво загострити тогочасну соціальну кризу, в т. ч. у сфері мовної політики, ставши підставою для політичного посилення протистояння всередині суспільства. Це фактично стало прикладом використання закону під впливом тогочасної політичної ситуації у країні з метою реалізації вузько політичних інтересів, націлених на посилення розшарування тогочасного суспільства, в т. ч. і за ознакою використання мови. На переконання вітчизняних вчених, прийняття вказаного законодавчого акта «не лише не сприяло удосконаленню правового забезпечення вживання державної та регіональної мов в Україні, але і значно поглибило соціально-гуманітарну кризу в суспільстві та сприяло подальшому розшаруванню суспільства за ознакою вживання мови. Надалі цей Закон України був визнаний таким що не відповідає Конституції України (є неконституційним)» [17]. Внесені зміни та доповнення до зазначеного законодавчого акта, в т. ч. скасування так званих соціально конфліктних положень [18; 19], призвело до погіршення міждержавних відносин із державами-сусідами України, зокрема з Угорщиною, Румунією та Республікою Польща. Вказане так само є прикладом того, як недоліки взаємодії законотворчості та політичного плюралізму відбиваються у змісті законодавчих актів і на самих суспільних відносинах як внутрішньодержавного, так і міждержавного рівнів.

У 2019 р. під впливом широкого кола політичних факторів шляхом низки політичних протистоянь і компромісів був ухвалений Закон України «Про забезпечення функціонування української мови як державної» від 25 квітня 2019 р. № 2704-VIII [20], положення якого, на нашу думку, до кінця не розв' язують можливість і гарантії віль- 
ного функціонування української мови, а також розвиток і використання мов національних меншин.

Висновки. У сучасних демократичних державах світу політичний плюралізм $\epsilon$ одним із головних принципів, що дозволяє говорити про його вплив, поширеність на всі сфери суспільного життя, включаючи і правову. Досвід взаємодії законотворчості та політичного плюралізму в таких країнах виявляється насамперед у гарантіях реалізації можливостей суб'єктам законотворчості або суб'єктам, що беруть участь у законотворчості, які їм надає політичний плюралізм. Закріплення принципу політичного плюралізму фактично визначає необхідність визначення відповідних гарантій. Такі гарантії можуть також бути закріплені конституційно, зокрема в положеннях ст. 15 Конституції України в загальному вигляді закріплено, що суспільне життя в Україні грунтується на засадах політичної, економічної та ідеологічної багатоманітності [14]. До таких гарантій переважно належать чітко визначене коло суб'єктів, наділених правом законодавчої ініціативи, наявність двопалатного парламенту, закріплення недоторканності парламентарів, особливий процесуальний порядок обговорення, розгляду законопроектів і голосування за них, законодавче закріплення права народу брати участь у законотворчості та наявність ефективно функціонуючого механізму його здійснення; визнання коаліції та опозиції як самостійних суб'єктів парламентських процесів, у т. ч. і щодо розгляду, обговорення та прийняття законодавчих актів тощо. Вказані гарантії є основою здійснення законотворчості та функціонування політичного плюралізму як явищ самостійних, водночас таких, що можуть існувати й ефективно функціонувати виключно на засадах взаємодії.

\section{Список використаних джерел:}

1. Закон України «Про вибори народних депутатів» від 25 березня 2004 р. № 1665-IV. URL: https:/ / zakon.rada.gov.ua/laws/show/1665-15.

2. Закон України «Про внесення змін до Закону України «Про вибори народних депутатів України» від 07 липня 2005 р. № 2777-IV. URL: https://zakon.rada.gov.ua/ laws/show/2777-15.

3. Закон України «Про вибори народних депутатів України» від 17 листопада 2011 p. № 4061-VI. URL: https:/ / zakon.rada.gov.ua/laws/show /4061-17.

4. Виборчий кодекс України від 19 грудня 2019 р. № 396-IX. URL: https://zakon.rada.gov.ua/laws/show/396-20\#n4128.

5. Шевченко Т.В. Прогалини в законодавстві, способи усунення і подолання. Право i суспільство. 2013. № 1. С. 23-26.

6. Податковий кодекс України від 02 грудня 2010 р. № 2755-VI. URL: https:/ / zakon.rada.gov.ua/laws/show/2755-17.

7. Закон України «Про внесення змін до Податкового кодексу України (щодо покращення інвестиційного клімату в Україні)» від 21 грудня 2016 р. № 1797-VIII. URL: https://zakon.rada.gov.ua/laws/show/1797-19.

8. Заславская Т.И., Громова Р.Г. Социальная стратификация в России. Путь $b$ XXI век (стратегические проблемы и перспективы российской экономики) / под ред. Д.С. Львова. Москва : Экономика, 1999. С. 134-155.

9. Василевич Г.А. Правотворческий процесс : учебное пособие. Минск : ГИУСТ БГУ, 2008. 304 с.

10. Куліш А.І. Лобізм. Юридична енциклопедія : в 6 т. / ред. кол. : Ю.С. Шемшученко та ін. Київ : Українська енциклопедія, 2003. Т. 3. С. 515.

11. Закон УРСР «Про мови в УРСР» від 28 жовтня 1989 р. № 8312-XI. URL: https:/ / zakon.rada.gov.ua/laws/show/8312-11/ed19891028\#Text. 
12. Закон України «Про ратифікацію Свропейської хартії регіональних мов або мов меншин, 1992 р.» від 24 грудня 1999 р. № 1350-XIV. URL: https://zakon.rada.gov.ua/ laws/show/1350-14\#Text.

13. Рішення Конституційного Суду України у справі за конституційним поданням 54 народних депутатів України щодо відповідності Конституції України (конституційності) Закону України «Про ратифікацію Свропейської хартії регіональних мов або мов меншин, 1992 р.» (справа про ратифікацію Хартії про мови, 1992 р.) від 12 липня 2000 p. № 9-рп/2000. URL: https:/ / zakon.rada.gov.ua/laws/show/v009p710-00\#Text.

14. Конституція України від 28 червня 1996 р. № 254к/96-BP. URL: http:/ / zakon0.rada.gov.ua/laws/show/254\% D0\% BA/96\% D0\% B2\% D1\% 80/print1419249647141480.

15. Закон України «Про ратифікацію Европейської хартії регіональних мов або мов меншин» від 15 травня 2003 р. № 802-IV. URL: https://zakon.rada.gov.ua/laws/ show /802-15\#Text.

16. Закон України «Про засади державної мовної політики України» від 03 липня 2012 p. № 5029-VI. URL: http:/ / zakon0.rada.gov.ua/laws/show/5029-17.

17. Рішення Конституційного Суду України у справі за конституційним поданням 57 народних депутатів України щодо відповідності Конституції України (конституційності) Закону України «Про засади державної мовної політики» від 28 лютого 2018 p. № 2-p/2018. URL: http:/ / ccu.gov.ua/sites/default/files/docs/2-p_2018.pdf.

18. Закон України «Про освіту» від 05 вересня 2017 р. № 2145-VIII. URL: https:/ / zakon.rada.gov.ua/laws/show/2145-19\#n1235.

19. Закон України «Про внесення змін до деяких законів України щодо частки музичних творів державною мовою у програмах телерадіоорганізацій» від 16 червня 2016 p. № 1421-VIII. URL: https:/ / zakon.rada.gov.ua/laws/ show/1421-19\#n47.

20. Закон України «Про забезпечення функціонування української мови як державної» від 25 квітня 2019 р. № 2704-VIII. URL: https://zakon.rada.gov.ua/laws/ show /2704-19\#Text. 


\title{
ПИТАННЯ ЦИВІЛЬНОГО, ГОСПОДАРСЬКОГО ТА ТРУДОВОГО ПРАВА
}

\author{
УДК 347.91/95:007:004.056.52 \\ DOI https://doi.org/10.32850/LB2414-4207.2020.14.11
}

\section{ПРАВОВИЙ СТАТУС ІНФОРМАЦІЇ ТА ПОНЯТТЯ «ІНФОРМАЦІЯ 3 ОБМЕЖЕНИМ ДОСТУПОМ»}

\author{
Гонгало Регіна Францівна, \\ кандидат юридичних наук, доцент, \\ доцент кафедри цивільного процесу \\ (Національний університет \\ «Одеська юридична академія», \\ м. Одеса, Україна)
}

У статті викладено наукові результати аналізу положень Конституції України, зокрема, про рівність громадян перед законом (ст. 24), про ознайомлення в органах державної влади та місцевого самоврядування, установах і організаціях 3 відомостями про себе, які не є державною таємницею (ст. 32), про право кожного вільно збирати, зберігати, використовувати і розповсюджувати інформацію усно, письмово чи будь-яким іншим способом (ст. 34), знати свої права та обов'язки (ст. 57) тощо.

За своїм правовим статусом інформація є особливим об'єктом цивільних прав. По-перше, інформація є благом не матеріальним, хоч і має матеріальні носії (папір, диски, дискети, плівки). По-друге, за своїми фізичними властивостями вона $є$ благом неспоживчим, тому що використання останньої за призначенняv не призводить до зменшення пї обсягу чи фізичного знищення. Інформація може лише застаріти і тому залишається не витребуваною, або у разі необхідності змінюється на актуальну. По-третє, інформація має різноманітні форми іiі фіксації, використання, поширення тощо.

Закон України «Про інформацію» своєю чергою визначає, що право власності на інформацію - це врегульовані законом суспільні відносини щодо володіння, користування і розпорядження інформацією, власник інформації має право призначати особу, яка здійснює володіння, використання і розпорядження інформацією, і визначати правила обробки інформації та доступу до неї, а також встановлювати інші умови щодо інформації (ст. 38).

На відміну від інших об'єктів, цінність інформації визначається її широким використанням у всіх сферах людської діяльності. У зв' язку з цим вона у всьому світі визначається товаром (об'єктом права власності).

Водночас у міжнародному праві передбачаються випадки обмеження права на свободу слова та доступ до інформації, визначаються правові режими окремих видів інформації з обмеженим доступом. Українське законодавство також 
містить низку норм, які регулюють питання щодо забезпечення права власності громадян на інформацію з обмеженим доступом, наприклад, це державна, комерційна, службова, військова або банківська таємниця.

Ключові слова: інформація з обмеженим доступом, таємниця нарадчої кімнати, судова практика, правова колізія, позивач, розпорядник, практика ВС.

\title{
LEGAL STATUS OF INFORMATION AND THE CONCEPT OF "RESTRICTED INFORMATION"
}

\author{
Gongalo Regina Frantsivna, \\ Doctor of Law, Associate Professor, \\ Associate Professor at the Department of \\ Civil Procedure \\ (National University “Odessa Law \\ Academy", Odessa, Ukraine)
}

The article presents the scientific results of the analysis of the provisions of the Constitution of Ukraine, in particular, on equality of citizens before the law (Article 24), on acquaintance in public authorities and local governments, institutions and organizations with information about themselves that is not a state secret (Article 32 ), the right of everyone to freely collect, store, use and disseminate information orally, in writing or in any other way (Article 34), to know their rights and responsibilities (Article 57), etc.

By its legal status, information is a special object of civil rights. First, information is a non-material good, although it has material media (paper, disks, floppy disks, films). Secondly, in terms of its physical properties, it is a non-consumer good, because the use of the latter for its intended purpose does not lead to a reduction in its volume or physical destruction. The information can only become obsolete, and therefore remains unclaimed, or, if necessary, changed to relevant. Third, information has various forms of its fixation, use, dissemination, and so on.

The Law of Ukraine "On Information", in turn, stipulates that the right of ownership of information is regulated by law public relations regarding the possession, use and disposal of information, the owner of information has the right to appoint a person who owns, uses and disposes of $\neg$ no information, and determine the rules of information processing and access to it, as well as establish other conditions for information (Article 38).

Unlike other objects, the value of information is determined by its widespread use in all spheres of human activity. In this regard, it is defined worldwide as a commodity (object of ownership).

In addition, international law provides for cases of restriction of the right to freedom of speech and access to information, defines the legal regimes of certain types of information with limited access. Ukrainian legislation also contains a number of rules governing the ownership of restricted information, such as state, commercial, official, military or banking secrecy.

Key words: information with limited access, secrecy of the deliberation room, court practice, legal conflict, plaintiff, administrator, practice of the Supreme Court.

Постановка проблеми. Значення дослідження правового статусу інформації та поняття інформації з обмеженим доступом полягає у тому, що на цьому етапі розвитку суспільства важливим і необхідним складником механізму здійснення права на інформацію $є$ гарантування доступу кожного до відомостей про події та явища, що відбуваються в суспільстві, державі та навколишньому природному середовищі, 
а також є засобом його участі у суспільних і державних справах. Тому невипадково, що стандарти права людини і громадянина на свободу слова і права на інформацію закріплені в міжнародних договорах та в законодавстві багатьох країн світу. У них також зазначається, що свобода вираження поглядів і отримання інформації є практично необмеженою.

Стан дослідження теми. Науковцями та юристами-практиками неодноразово здійснено аналіз проблематики правового статусу інформації та поняття інформації з обмеженим доступом. Зокрема, цим питанням присвячені праці таких вчених, як Д.В. Бобров, О.О. Кулініч, А.І. Марущак, та інші.

Метою статті $\epsilon$ моніторинг українського законодавства у сфері правового режиму інформації з обмеженим доступом, надання загальної характеристики правовому статусу інформації, розкриття поняття та змісту інформації з обмеженим доступом.

Виклад основного матеріалу. В сучасному українському законодавстві поняття «інформація» розкривається досить обмежено. Насамперед визначення інформації надається в Цивільному кодексі України, Законах України «Про інформацію», «Про захист економічної конкуренції».

Так, ст. 200 Цивільного кодексу України (далі - ЦКУ) зазначає, що інформацією $\epsilon$ будь-які відомості та/або дані, які можуть бути збережені на матеріальних носіях або відображені в електронному вигляді [1].

Своєю чергою Закон України «Про інформацію» надає своє визначення. Так, у ст. 1 під поняттям «інформація» розуміються документовані або публічно оголошені відомості про події та явища, що відбуваються у суспільстві, державі та навколишньому природному середовищі [2].

За роки незалежної України багато науковців, досліджуючи питання правової природи поняття «інформація», також сформулювали своє визначення. Так, зазначається, що інформація (лат information - роз'яснення, уявлення) - документовані або публічно оголошені відомості про події та явища, що відбуваються у суспільстві й державі та навколишньому середовищі.

Сучасна доктрина цивільного права зазначає, що об'єктами цивільних прав визнаються матеріальні та нематеріальні блага, стосовно яких між суб'єктами цивільного права виникають відносини, що складають предмет цивільно-правового регулювання. В ст. 177 ЦКУ наводиться перелік таких об'єктів: речі, включаючи гроші і цінні папери, інше майно, майнові права, результати робіт і послуг, інформація, результати інтелектуальної, творчої діяльності, а також інші матеріальні та нематеріальні блага.

За своїм правовим статусом інформація є особливим об'єктом цивільних прав. По-перше, інформація є благом нематеріальним, хоч і має матеріальні носії (папір, диски, дискети, плівки). По-друге, за своїми фізичними властивостями вона є благом неспоживчим, тому що використання останньої за призначенням не призводить до зменшення іiї обсягу чи фізичного знищення. Інформація може лише застаріти і тому залишається не витребуваною, або у разі необхідності змінюється на актуальну. По-третє, інформація має різноманітні форми ії фіксації, використання, поширення тощо.

Складником особистих немайнових благ, які передбачені ст. 201 ЦКУ, є право на інформацію. Яке поділяється на: а) абсолютні права, коли одній особі протистоїть невизначене коло осіб, що зобов' язані утримуватися від порушення іiї прав; б) відносні права, що належать учасникам правовідносин, у яких уповноваженій особі протистоять чітко визначені особи і вони повинні здійснювати або не здійснювати цілком визначені дії.

На відміну від інших об'єктів, цінність інформації визначається ії широким використанням у всіх сферах людської діяльності. У зв' язку з цим вона у всьому світі визначається товаром ( об'єктом права власності) [3]. 
В українському законодавстві інформація також є об'єктом права власності. Так, у Законі України «Про наукову технічну-інформацію» чітко вказано те, що науково-технічна інформація є об'єктом права власності (ст. 6).

Закон України «Про інформацію» своєю чергою визначає, що право власності на інформацію - це врегульовані законом суспільні відносини щодо володіння, користування і розпорядження інформацією, власник інформації має право призначати особу, яка здійснює володіння, використання і розпорядження інформацією, і визначати правила обробки інформації та доступу до неї, а також встановлювати інші умови щодо інформації (ст. 38).

Ст. 39 визначає те, що інформаційна продукція та інформаційні послуги громадян та юридичних осіб, які займаються інформаційною діяльністю, можуть бути об'єктами товарних відносин, що регулюються чинним цивільним та іншим законодавством (ст. 39).

Суттєвим для правового статусу «інформації»є те, що суб'єкт відносин у сфері інформації може вимагати усунення порушень його права та відшкодування майнової та моральної шкоди, завданої такими правопорушеннями (ч. 2 ст. 200 ЦКУ).

Відповідно до ч. 2 ст. 34 Конституції України кожен має право збирати, зберігати, використовувати і поширювати інформацію усно, письмово або в інший спосіб - на свій вибір. Водночас ч. 3 ст. 34 КУ наводить підстави, за яких закріплені в цій статті права можуть бути обмежені державою. В ній також зазначається, що такі обмеження можуть встановлюватися виключно за допомогою закону.

Всі підстави, які перелічені в зазначеній нормі Конституції України, поділяються на три види: загальносоціальні, особисті, політичні. Всі ці підстави передбачені в міжнародно-правових актах з прав людини.

Існує правовий режим інформації. Так, у Законі України «Про інформацію» визначено, що режим доступу до інформації - це передбачений правовими нормами порядок одержання, використання, поширення і зберігання інформації (ч. 1 ст. 28), яка своєю чергою поділяється на «відкриту інформацію» та «інформацію з обмеженим доступом» (ч. 2 ст. 28).

Доступ до відкритої інформації забезпечується шляхом:

1) систематичної публікації іiі в офіційних друкованих виданнях (бюлетенях, збірниках);

2) поширення ії через 3MI;

3) безпосереднє надання ії за запитом громадян, державних органів, юридичних осіб і представників громадськості.

Обмеження права на одержання відкритої інформації забороняється законом [4].

В сучасному законодавстві поняття «інформація з обмеженим доступом» тривалий час $є$ об'єктом дослідження. Науковці аналізують зміст поняття «інформація з обмеженим доступом», яке знайшло відображення в міжнародних актах:

- «інформація з обмеженим доступом» - це інформація, право доступу до якої обмежено відповідно до національного законодавства держав Сторін (ст. 1 Угоди між КМУ та Урядом Республіки Білорусь про співпрацю в галузі технічного захисту інформації);

- «інформація з обмеженим доступом» - інформація у будь-якій формі та будьякі документи, матеріали, вироби, речовини або фізичні поля, в яких представлена інформація, яка в інтересах національної безпеки держав Сторін та відповідно до ïx національного законодавства підлягає охороні від несанкціонованого доступу, включаючи інформацію, яку спільно створено юридичними особами держав Сторін в рамках співробітництва та доступ до якої обмежено на основі вимог національ- 
ного законодавства держав Сторін та відповідно до критеріїв цієї Угоди (ст. 1 Угоди між КМУ та урядом Словацької Республіки про взаємну охорону інформації з обмеженим доступом);

- «інформація 3 обмеженим доступом» - будь-яка інформація у сфері оборони незалежно від ії фізичної форми або характеристики, яка в інтересах національної безпеки держави будь-якої Сторони була визначена як така, що вимагає захисту від несанкціонованого розкриття та позначена грифом обмеження доступу (ст. 1 Меморандуму про взаєморозуміння між КМУ та Урядом Сполученого Королівства ВБ та Північної Ірландії щодо обміну та взаємної охорони інформації з обмеженим доступом у сфері оборони).

Відповідно до ст. 3О 3У «Про інформацію» за своїм правовим режимом інформація з обмеженим доступом поділяється на:

- конфіденційну інформацію - це відомості, які знаходяться у володінні, користуванні або розпорядженні окремих фізичних та юридичних осіб і поширюються за їх бажанням відповідно до передбачених ними умов;

- таємну інформацію - це своєю чергою відомості, які становлять державну та іншу передбачену законом таємницю, розголошення якої завдає шкоди особі, суспільству та державі.

У науковців склалося своє визначення поняття «інформація з обмеженим доступом». У своїй праці О.О. Кулініч визначає, що «інформація з обмеженим доступом»це певні соціально цінні відомості, дані, знання, доступ до яких обмежується певними суб'єктами (володільцями) шляхом ужиття заходів та мір організаційно-технічного, правового характеру, невжиття яких може спричинити настання моральної та/або матеріальної шкоди внаслідок незаконних дій з інформацією, за вчинення яких для винних суб'єктів настає юридична відповідальність відповідно до норм чинного законодавства [4].

Своєю чергою А.I. Марущак визначає, що «інформація з обмеженим доступом» це відомості конфіденційного або таємного характеру, правовий статус яких передбачений законодавством України, які визначені такими відповідно до встановлених юридичних процедур, і право на обмеження доступу до яких надано власнику таких відомостей [5].

В українському законодавстві спеціальними НПА визначена: державна таємниця (ст. 1 3У «Про державну таємницю»), комерційна таємниця (ст.ст. 36, 162 ГК, ст.ст. 505-508, 1076 ЦК, ст.ст. 16-19 3У «Про захист від недобросовісної конкуренції» тощо), військова таємниця (ст.ст. 1,8 3У «Про державну таємниця»), адвокатська таємниця (ст. 22 3У «Про адвокатуру та адвокатську діяльність»), банківська таємниця (ст. 60 3У «Про банки і банківську діяльність»), таємниця голосування (ст. 7 ЗУ «Про вибори Президента України», ст. 7 «Про вибори народних депутатів України»), медична таємниця (ст. 40 3У «Основи законодавства про охорону здоров'я»), таємниця вчинюваних нотаріальних дій (ст. 8 3У «Про нотаріат»), таємниця усиновлення (ст. 226 Сімейного кодексу України), таємниця сповіді (ст. 3 ЗУ «Про свободу совісті та релігійні організації»), таємниця нарадчої кімнати (ст. 367 КПК України, 245 ЦПК України, ст. 228 КАС України) та таємниця переписки, листування, переговорів тощо.

Як ми бачимо, в нашому правовому полі багато правових понять, які схожі між собою і мають стосунок до інформації з обмеженим доступом.

Як свідчить судова практика, у них відсутня між собою узгодженість, що призводить до судових помилок та правових колізій.

3 лютого 2020 року Верховний Суд оприлюднив огляд судової практики ВС у спорах щодо забезпечення права на доступ до публічної інформації. 
Огляд судової практики містить правові позиції Верховного Суду за 2018-2019 роки.

Розділи огляду присвячені таким питанням: визначення поняття «публічна інформація», інформація з обмеженим доступом, оформлення запитів на інформацію, відмова у задоволенні запиту на інформацію, право на оскарження рішень, дій чи бездіяльності розпорядників інформації.

Висновки. Отже, інформація надається з певним правовим режимом ії надання, та отримання інформації будь-якого характеру не може відноситися до абсолютного права кожної особи. Правовий режим надання інформації забезпечує охорону та захист прав інших суб'єктів права (фізичних, юридичних осіб та органів виконавчої влади, держави).

\section{Список використаних джерел:}

1. Цивільний процесуальний кодекс України від 18.03.2004 p. № 1618-IV. Вiдомості Верховної Ради України. 2004. № 40-44. Ст. 356.

2. Закон України «Про інформацію» № 2657 - XII від 02.10.1992 р. Відомості Верховної Ради України, 1992. № 48, ст. 650.

3. Боброва Д.В. Цивільне законодавство. В кн.: Загальна теорія цивільного права: Підручник / за заг.ред. О.А. Підопригори, Д.В. Бобрової. Київ, 1992. С. 38.

4. Кулініч О.О. Загальні положення про інформацію з обмеженим доступом в цивільному праві. Монографія. Одеса : Видавництво Букеєв В.В. 2008 р. С. 25.

5. Марущак А.І. Інформаційне право. Доступ до інформації: навчальний посібник. Київ : КНТ, 2007. С. 46. 
УДК 347.9

DOI https:// doi.org/10.32850/LB2414-4207.2020.14.12

\title{
ЦИФРОВІЗАЦІЯ ПРАВОСУДДЯ ТА ДОСТУП ДО ПРАВОСУДДЯ ПІД ЧАС COVID
}

\author{
Каламайко Андрій Юрійович, \\ кандидат юридичних наук, \\ асистент кафедри цивільного процесу \\ (Національний юридичний університет \\ імені Ярослава Мудрого, \\ м. Харків, Україна)
}

COVID-19 порушив роботу не тільки сектора охорони здоров'я, а й системи правосуддя. Судам у всьому світі довелося швидко відреагувати на проблеми, пов'язані 3 пандемією, та віднесені до неї обмеження та потребу в соціальному дистанціюванні. Це створило значні проблеми для системи правосуддя, і такі проблеми, ймовірно, ще більш ускладняться в постпандемічну епоху. Стаття присвячена питанням переходу в глобальному вимірі судів від традиційних очних судових розглядів до онлайнових судових процесів (із використанням мережі Інтернет). Застосовуючи порівняльний підхід, буде проаналізовано, яким чином деякі країни дійшли такого переходу на онлайновий режим, зберігаючи водночас акцент на доступності правосуддя. Убачається, що способи врегулювання суперечок у режимі онлайн (ODR) можуть сприяти їх розв' язанню та водночас соціальному відчуженню в цій новій епосі COVID. Швидкий перехід від традиційних судових процесів до онлайнового способу ще більше допоміг громадськості та юристам отримати доступ до системи правосуддя в деяких юрисдикціях навіть під час кризи. У світлі масштабів нещодавніх змін висловлювалися побоювання щодо спроможності судів впроваджувати новіші технології, а також щодо питань, пов'язаних із впливом нової онлайнової моделі здійснення правосуддя, особливо з боку бар'єрів для найбільш незахищених членів суспільства. Крім того, використання новітніх технологій у деяких судах поставило питання про те, чи відбивають результати, отримані завдяки цим нововведенням, значення поняття «правосуддя» в його традиційному розумінні. У статті стверджується, що судам слід використовувати новіші технології, які допомагають здійснювати судочинство, не забуваючи водночас про можливі технічні питання, які можуть вплинути на цілі правосуддя. Додатковий акцент зроблено на альтернативних методах врегулювання спорів і ODR в майбутньому, які допоможуть компенсувати ймовірне цунамі пов' язаних із COVID судових розглядів, які дозволять судам, лікарням, медичним працівникам і пацієнтам розв'язати суперечки справедливим, рівноправним та ефективнішим чином.

Ключові слова: судові інновації, вирішення спорів, електронний суд, альтернативні способи вирішення спорів, COVID-19. 


\title{
DIGITIZATION OF JUSTICE AND ACCESS TO JUSTICE DURING COVID
}

\author{
Kalamaiko Andrii Yuriiovich, \\ $\mathrm{PhD}$, \\ Assistant Professor at the Department \\ of Civil Procedure \\ (Yaroslav Mudryi National \\ Law University, \\ Kharkiv, Ukraine)
}

COVID-19 disrupted not only the health sector but also the justice system. Courts around the world have had to respond quickly to the pandemic and its limitations and the need for social distancing. This has created significant problems for the justice system, and such problems are likely to become even more complicated in the post-pandemic era. This article focuses on the transition in the global dimension of courts from traditional faceto-face trials to online trials (using the Internet). Using a comparative approach, it will analyze how some countries have moved to such an online transition, while maintaining an emphasis on access to justice. It is seen that online dispute resolution (ODR) methods can help resolve them and at the same time contribute to social exclusion in this new era of COVID. The rapid transition from traditional to online trials has further helped the public and lawyers to access the justice system in some jurisdictions, even in times of crisis. In light of the scale of recent changes, concerns have been expressed about the ability of courts to introduce newer technologies, as well as issues related to the impact of a new online model of justice, especially in terms of barriers for the most vulnerable. In addition, the use of new technologies in some courts has raised the question of whether the results obtained through these innovations reflect the meaning of the concept of "justice" in its traditional sense. This article argues that courts should use newer technologies to assist in the administration of justice, without forgetting possible technical issues that may affect the goals of justice. Additional emphasis is placed on alternative dispute resolution and ODR methods in the future to help offset the likely tsunami of COVID-related litigation, which will allow courts, hospitals, healthcare professionals and patients to resolve disputes fairly, equitably and more effectively.

Key words: judicial innovations, dispute resolution, electronic court, alternative dispute resolution, COVID-19.

Пандемія COVID-19 стала справжнім випробуванням для людства та яскраво продемонструвала наявні недоліки в багатьох сферах суспільного життя. I хоча предметом пильної уваги з боку засобів масової інформації став вплив пандемії на системи охорони здоров'я, сектор правосуддя теж потребує дослідження. Традиційні судові системи, засновані на застарілих технологіях, часто насилу справлялися зі світом, в якому вимагалося соціальне дистанціювання, віддалене розташування та електронний обмін документами. Водночас зміни, які були внесені в судовий сектор, не були однаковими. Це пояснюється тим, що в деяких юрисдикціях діють більш «сучасні» суди (які могли б більш ефективно використовувати сучасні технологіі), в той час як у багатьох місцях суди продовжують застосовувати підходи до судових розглядів, які існували десятиліттями (або навіть століттями).

В одних частинах системи правосуддя відзначалося зростання робочого навантаження, в той час як в інших - зниження. Наприклад, у секторі кримінального правосуддя зросла потреба в перегляді порядку звільнення під заставу й утримання під вартою для того, щоб скоротити кількість ув'язнених за можливості [1]. Водно- 
час спостерігалося деяке скорочення цивілістичних процесів, оскільки економічна діяльність скоротилася.

Насправді можна вважати щасливим збігом обставин, що в короткостроковій перспективі потреба в судочинстві дещо знизилася, оскільки багато судів по всьому світу просто не змогли перейти на віддалений режим роботи. Цьому є дві причини. По-перше, багато судів не оцифровані й не мають електронної пошти та інших механізмів. Простіше кажучи, в багатьох випадках залишилась залежність від обміну паперовими документами. По-друге, до пандемії COVID-19 лише в поодиноких судах були засоби для проведення відеоконференцій як способу розв' язання питань, пов' язаних iз проміжними або остаточними слуханнями. У відповідь на COVID-19 багато судів швидко впровадили допоміжні технології, які дозволяли проводити відеоконференції, а іноді й обмін документацією з використанням вебплатформ, що містять Teams, Skype, Zoom, Google Hangouts i WebEx. Деякі суди вже мають у своєму розпорядженні онлайнові системи подачі позовів і тому більшою мірою готові до віддаленої роботи. Однак іншим доводиться стикатися 3 труднощами, пов'язаними 3 проведенням відеоконференщій, включаючи проблеми, пов'язані 3 конфіденційністю даних і безпекою, а також з особливими труднощами, що виникають у зв'язку зі слуханнями за участю присяжних [2]. Зовнішні суди, в яких проводиться велика робота по здійсненню правосуддя, механізми врегулювання суперечок в режимі онлайн (далі - ODR) стають все більш важливим напрямком діяльності через збільшення затримок у багатьох судових системах.

Далі наводяться приклади, коли суди в усьому світі впровадили технології для підтримки роботи судів, з особливим акцентом на Китай і те, як китайські суди відреагували на проблеми, пов'язані з COVID-19. Автори повідомляють, що, незважаючи на значне зростання числа онлайнових справ у китайських судах, пов' язаний із цим тиск певною мірою компенсується стратегією країни по створенню системи «розумних судів». Однак незважаючи на значний прогрес, якого, як видається, відразу домоглися суди в усьому світі в справі прийняття онлайнової моделі розгляду справ, з боку доступу до правосуддя як і раніше існують значні проблеми. Останнім питанням, яке розглядається, є очікуване «цунамі» суперечок у період після пандемії [3], в тому числі в галузі охорони здоров'я, що виникають у зв'язку з COVID-19, а також впливи для країн, які найбільше постраждали від цього вірусу.

Суди й судді можуть використовувати технології для здійснення правосуддя, взаємодії з громадськістю та користувачами, а також для підтримки функцій сортування, розв'язання спорів, самодопомоги й управління справами. Крім того, суди можуть використовувати можливості, що надаються технологією, для зміни методів роботи й функціонування судів, а також для зміни порядку проведення реформ. Однак дотепер більшість судів використовували технологію для відтворення наявних систем і процесів замість того, щоб зосередитися на реформуванні структур і процесів, що існують в системі правосуддя. У результаті багато судів і раніше нагадують суди минулого століття (та навіть позаминулого). Як зазначив на рубежі минулого століття один видатний колишній суддя Високого суду Австралії, «адвокат із часів Діккенса, завітавши в сучасний австралійський суд у звичайний день, побачив би відносно мало змін. Ті ж перуки й мантії. Дуже схожі основні процедури подання доказів і наведення аргументів. Більш довгі рішення: але все та ж структура фактів, права й висновків. I навпаки, уявіть здивування лікаря з лондонської лікарні середини минулого століття, блукаючого в електронному світі біперів і моніторів, комп' ютерних томографів, геномних тестів та автоматизованої діагностики сучасної австралійської лікарні. Ми домоглися прогресу в області права й в судах, в тому числі і за останні двадцять п'ять років. Але не так багато, як в інших професіях. Чи залишиться це так?» [4, с. 143] 
Хоча пандемія COVID-19 привела до численних змін в тому, як діють суди, однак і досі багато судів у всьому світі продовжують вести процеси дуже схоже на те, як це було десятиліття або навіть століття тому. Іноді відзначається, що й судді, й суди неохоче йдуть на нововведення та можуть бути за своєю суттю консервативними. Однак між окремими суддями й судами існують значні відмінності в тому, що стосується судових підходів до технології.

Так, у Сполучених Штатах Америки Федеральний Окружний Апеляційний Суд всі справи, заплановані до розгляду в квітні, травні й червні 2020 року, проводив дистанційно, й сторони більше не повинні були подавати додаткові документи на паперових носіях, якщо вони були подані в електронному вигляді. Крім того, 3 метою сприяння застосуванню принципів відкритого судочинства Суд також забезпечував аудіодоступ до аргументів у прямому ефірі, а на вебсайті Суду щодня розміщувалася інформація про доступ до них. Судовими органами використовувалися різні технології конференц-зв'язку: AT\&T Conferencing, Court Call, Skype for Business, Cisco Jabber i Zoom.

Верховний Суд Сполучних Штатів Америки, починаючи з травня 2020 року, заслухав усі усні аргументи дистанційно за допомогою телефонної конференції. Суд також забезпечив «пряму аудіотрансляцію аргументів для FOX News, Associated Press i C-SPAN», яка своєю чергою забезпечила «одночасну трансляцію усних аргументів для пожвавлення на різних медіаплатформах».

Кримінальний суд Нью-Йорку станом на 25 березня 2020 року провів усі кримінальні справи за допомогою технології відеоконференцзв' язку. Модель віртуального суду була впроваджена в кожному графстві з 6 квітня 2020 року з використанням аудіовізуального й телефонного зв' язку, а також цифрового обміну документами. Головний суддя ДіФьоре заявив, що, незважаючи на поступове відкриття судів 3 липня 2020 року й далі, віртуальні операції будуть залишатися невіддільною частиною судових систем.

Апеляційний суд штату Нью Йорк 11 травня 2020 року направив в адвокатуру повідомлення про внесення змін до свого Регламент із тим, щоб «вимагати, для клопотань і відповідей на юрисдикційні запити, уявлення в цифровому форматі через портал для завантаження файлів компаньйона». Апеляційний суд буде також приймати подання поштою та в електронній формі. Усні аргументи будуть як і раніше транслюватися по Інтернету в прямому ефірі до вересневої сесії.

Верховний Суд Онтаріо 2 квітня 2020 року скасував вимогу про подання документів у паперовій формі; підтвердив прийняття документів, підписаних електронним способом; дозволив електронне обслуговування документів у тих випадках, коли потрібне персональна обслуговування, та заслуховував справи практично по телефону або в режимі відеоконференції. Суд також передав фінансування міністерством посередницьких послуги в сімейних справах практично в розпорядження сторін.

Що стосується Азії, то Верховний Суд Індії постановив, що «важливі питання» заслуховуються за допомогою відеоконференцій, а терміни давності тимчасово припиняються Судом. У Катарі матеріали слухалися дистанційно з використанням технології відеоконференцій. Дубай із 19 квітня 2020 року проводив слухання в електронному вигляді через Microsoft Teams, що дозволяло заслуховувати сторони в режимі відеоконференції.

Високий суд Австралії постановив у справах, які розпочаті 1 січня 2020 року або пізніше, всі документи подавати в режимі онлайн, використовуючи портал Системи цифрового розміщення. Послуги секретаріату Суду надаються в режимі онлайн або по телефону; документи повинні подаватися до Суду в електронному вигляді; Суд тимчасово дозволяє ставити електронні підписи на документах. 
Верховний Суд Північної Території Австралії вирішив всі досудові слухання проводити за допомогою аудіовізуального зв' язку або телефонної конференції. До впровадження Інтегрованої системи ведення справ «Одіссея» в жовтні 2020 року всі документи в цивільних справах будуть продовжать подаватися в електронному вигляді.

Верховний Суд Нового Південного Уельсу з 24 березня 2020 року в справах, за винятком «виняткових обставин», заборонив особисті явки, а всі документи повинні були надаватися в електронному вигляді. Закон про докази (aydio- ú aydiobiзуальним зb'язком) 1998 року (NSW) був змінений, щоб дозволити свідкам або юристам-практикам з'являтися в суді за допомогою аудіовізуальних або цифрових технологій, якщо суд дасть відповідну вказівку.

Верховний Суд Квінсленду вирішив, що сторони й фахівці-практики повинні були виступати тільки в тих випадках, коли це питання не могло бути «практично розв'язане по телефону або відеокамері».

У Верховному Суді Вікторії цивільні позови заслуховувалися дистанційно за допомогою WebEx , Skype або Zoom, а також кримінальні справи були заслухані за допомогою WebEx або наявної технології відеозв'язку. Крім того, документи подавалися в Суд в електронному вигляді, й із метою полегшення віддаленого доступу Суд приймав письмові свідчення без присяги за умови, що вони відповідали певним вимогам, опублікованим на вебсайті Суду.

У Великобританії був створений «Суд у сімейних справах із віддаленим доступомй, який дозволив проводити слухання практично з використанням, наприклад, Skype for Business. Ці віддалені слухання були підтримані технологією “e-bundling” шляхом впровадження хмарної відеоплатформи в липні 2020 року в залах судових засідань у цивільних, сімейних і кримінальних справах. Ця платформа дозволяє суддям і сторонам отримувати доступ до документів, які подаються в електронному вигляді.

Італійський Верховний суд спочатку повністю припинив всю судову діяльність. Однак станом на 16 квітня 2020 року було реалізовано «заходи з електронного судочинства для будь-якого виду судової діяльності, як цивільної, так і кримінальної». Відповідно, такі питання розв' язуються виключно на «захищених онлайнових платформах», що дозволяє сторонам виступати за допомогою технології відеоконференцій.

У Британській Колумбії в Канаді трибунал із розв' язання цивільних спорів (далі (RT) є трибуналом по врегулюванню суперечок у режимі онлайн, який розглядає, зокрема, прості питання, пов'язані $з$ тілесними ушкодженнями, зайнятістю, будівництвом і майном. Заявники подають онлайн-заяву на дозвіл їх спору в CRT. Потім система автоматично класифікує суперечку й надає заявникам необхідні документи для подачі позову. Після цього сторони можуть подавати подання та докази для оцінки членами суду в режимі онлайн. Дійсно, якщо потрібно усне слухання, воно проводиться через Skype.

Хоча CRT діяв до COVID-19, його суто цифровий характер дозволив йому «залишатися повністю працездатним» із моменту спалаху.

Пекінський інтернет-суд є одним з трьох «віртуальних судів» у Китаї. Ці суди займаються тим, що називається «електронними судами»: процедури «судового розгляду», які дозволяють проводити весь процес судового розгляду від «подачі заяви до ухвалення рішення та посередництва» в режимі онлайн. Система функціонує 24 години на добу й після пандемії розслідує процедури, спрямовані на «встановлення протоколів судових розглядів у режимі онлайн в кіберпросторі».

Цей суд також має те, що називається «пересувний мікросуд». Це дозволяє сторонам виступати через WeChat - провідну соціальну медійну платформу Китаю. Це особливо корисно для осіб, які не мають легкого доступу до комп' ютера під час спалаху COVID-19 [5]. 
Таким чином, значне число судів у всьому світі у відповідь на COVID-19 у терміновому порядку перейшли на онлайновий режим. Однак, незважаючи на загальні переваги продовження надання судових послуг, використання Інтернету й інших онлайнових технологій в системі правосуддя породило цікаві питання, що стосуються впливу на право доступу до правосуддя, право на справедливий судовий розгляд і на відправлення правосуддя в більш широкому плані. Зокрема, право на доступ до правосуддя $є$ одним з основоположних принципів міжнародного права прав людини й невіддільною частиною верховенства права й принципу рівності перед законом [6; 7].

Принцип доступу до правосуддя розглядається як всеосяжний принцип, який повинен тлумачитися в контексті з іншими правами в Конвенції. Доступ до правосуддя також стосується ряду інших прав, включаючи право на доступ до процедур, інформації та місць, що використовуються в процесі здійснення правосуддя, а також право на розгляд справи без невиправданої затримки. Таким чином, воно повинно враховуватися у всіх способах розв' язання спорів і дотримуватися в тих державах, які ратифікували закони про права людини.

У зв' язку із цим, хоча стаття і присвячена насамперед організації судочинства, важливо відзначити, що в багатьох країнах суди вже не сприймаються як епіцентр системи правосуддя. Хоча очевидно, що суди відіграють найважливішу роль у підтримці верховенства права, а також у забезпеченні прав, реальність така, що більшість людей, які знаходяться в спорі, розв'язують свої суперечки до початку судового розгляду й часто використовують для цього форми альтернативного розв' язання спорів (ADR) або врегулювання суперечок у режимі онлайн (ODR). Дійсно, в багатьох країнах процедури санкціоновані до початку судового розгляду, а після того, як розгляд все-таки починається, передача справи на врегулювання в режимі ADR також часто є обов'язковою. Такі процеси також є частиною рівняння доступу до правосуддя, та в цілому адаптація системи правосуддя в епоху COVID19 була дещо менш проблематичною в деяких правових системах почасти тому, що у зв' язку з ODR вже спостерігається певний розвиток і зростання.

У результаті пандемії деякі суди в усьому світі були змушені повністю закритися [8], в той час як інші (включаючи Свропейський суд із прав людини) тимчасово скоротили своє робоче навантаження, займаючись тільки «найважливішими» або «високопріоритетними» випадками. Значення того, що є істотним випадком, в різних юрисдикціях було різним. Наприклад, в Англії та Уельсі королівські суди класифікували невідкладні справи як справи, що вимагають прийняття рішення протягом тижня та є «істотними в інтересах правосуддя» [9]. Прийнявши технологію та визначивши пріоритетність справ на основі «невідкладності», багато судів змогли продовжити свою роботу, тим самим забезпечивши право доступу до правосуддя в цих екстрених випадках. Проте зберігаються значні побоювання у зв' язку зі збільшенням числа нерозглянутих справ і тривалими термінами очікування судових засідань у всьому світі. Це особливо стосується тих випадків, коли окремі особи не можуть скористатися належними засобами правового захисту або відстоювати свої основні права, зокрема право на свободу за допомогою Habeas Corpus, або коли ув'язнений має право на дострокове звільнення. Судові розгляди за участю присяжних також припинилися в багатьох юрисдикціях, і це мало різні наслідки. У деяких юрисдикціях, де більш поширені судові процеси тільки за участю суддів, вплив було не таким значним. В юрисдикціях, що включають деякі суди США, вплив був руйнівним із боку доступності судових слухань.

Крім значних затримок і періодів очікування, деякі групи громадян також будуть у непропорційно великій мірі зворушені закриттям судів або переходом на онлайнові 
способи доставки. Жінки, діти, особи, які перебувають в установах із надання притулку або в центрах утримання під вартою, а також інваліди вже стикаються зі значними проблемами під час відстоювання своїх прав, і ці проблеми, цілком ймовірно, ще більш загостряться в нинішніх умовах. Тому в процесі розгляду ролі технологій для підтримки судових органів і сприяння функціонуванню судової системи особлива увага повинна приділятися конкретним бар'єрам, які можуть перешкоджати повному включенню та участі сторін, від яких вимагається участь в онлайновій справі.

Як і в інших частинах світу, Китай зіткнувся з проблемами, викликаними пандемією, та пов'язаними з ними заходами із соціального відчуження, в тому числі 3 тим, як забезпечити право людей на доступ до правосуддя. Необхідність нормального функціонування системи правосуддя в країні підкреслюється особливою ситуацією в Китаї, де судді вже були перевантажені до пандемії через збільшення числа справ у зв'язку з великою кількістю населення та недавнім збілышенням обсягу роботи, викликаним зміною економічних і ділових умов. [11]. Крім того, багато послуг по ADR i ODR в Китаї пов'язані із судовою системою та не існують на зовнішній основі (на відміну від ситуації в таких юрисдикціях, як Австралія).

Одним з основних заходів, прийнятих у Китаї, є переведення судових процесів (включаючи реєстрацію справ, вручення судових документів, обмін доказами, слухання, ухвалення рішення та навіть забезпечення його виконання) в режим онлайн в цілях сприяння розширенню доступу до правосуддя. Натепер такі механізми добре розроблені в порівнянні з іншими судовими органами. Наприклад, за даними Верховного народного суду Китаю, в період з 3 лютого по 30 квітня 2020 року по всій країні було порушено 5,579 млн справ, з яких чверть була передана в електронному форматі, що на 24 відсотки більше за порівняно з тим же періодом 2019 року. Крім того, 16,60 відсотка з 1,51 мільйона слухань за цей час було проведено дистанційно, що на 943 відсотка більше в порівнянні з тим же періодом 2019 року [12].

Передбачається, що готовність китайських судів до викликів, які виникають у зв'язку з пандемією, є результатом стратегії побудови системи «розумних судів» шляхом використання технологічних інновацій для надання «швидких» $\mathrm{i}$ «справедливих» послуг своїм громадянам. Поняття «розумний суд», вперше офіційно висунуте головою КПК в 2016 році, не належить до одного конкретного суду. Швидше, цей термін належить до «організаційної, конструктивної та операційної моделі народних судів, заснованої на передових інноваціях із метою досягнення справедливої судової системи й справедливості для людей шляхом підтримки онлайн-сервісів інтелектуальних судів протягом усього процесу розв'язання спорів у прозорому середовищі» [13]. Характеристики інтелектуального суду містять «забезпечення справедливості й ефективності судової системи й підвищення довіри до судової системи, вилучення максимальної вигоди з технологій, включаючи Інтернет, хмарні обчислення, великі дані й Ш, сприяння модернізації судової системи й можливостей Китаю, а також досягнення високоінтелектуального функціонування та управління народними судами» [14]. Повідомлялося, що до червня 2019 року в Китаї сформувалася система «Розумний суд», яка відповідно до закону [15] надає загальнодоступні онлайн-послуги в рамках всього процесу.

Розумний суд має на увазі, що правосуддя може бути реалізовано через онлайн-портали, й ці портали в основному беруть форму вебплатформ для судових розглядів. Наприклад, Високий народний суд Чжецзян у Східному Китаї створив всеосяжну онлайнову платформу для надання сторонам онлайнового доступу до послуг без необхідності звертатися до суду для подачі позову. Ця платформа також дозволяє проводити слухання в режимі онлайн (за допомогою відеоконференцій) після того, 
як сторони увійдуть у систему з присвоєним їм «кодом судового процесу». Як зазначалося вище, після спалаху COVID-19 на віддалені слухання припадає значна частка всіх судових розглядів в Китаї в контексті заходів із подолання соціального відчуження. Серед них першим судовим розглядом із використанням відеоконференцій, пов'язаних з пандемією, стала справа про шахрайство, яка була проведена 7 лютого в місцевому суді в провінції Цзянсу. Обвинувачений був звинувачений у заробітку на неправдивій обіцянці поставити певну кількість хірургічних масок для обличчя. Судовий процес проводився дистанційно за участю суддів, прокурорів, підсудного й адвокатів захисту, які засідали в чотирьох різних місцях. Очевидно, що підхід до слухань у режимі онлайн дозволив своєчасно завершити цю справу, уникаючи водночас на тривалі проміжки часу тримання обвинуваченого під вартою.

На додаток до вебплатформ китайські суди також розробили прикладні програми в галузі правосуддя (“аррs”, «додатки»), які полегшили доступ до правосуддя, особливо для молодих людей, які звикли користуватися мобільними телефонами для проведення різних повсякденних заходів. Наприклад, СТС розробив додаток «Мобільний мікросуд» і із серпня 2018 року поширив його в усіх судах країни. Ця програма дозволяє користувачам здійснювати онлайнову подачу документів, дистанційно відвідувати суд, обмінюватися доказами в режимі онлайн та інші пов'язані із цим судові функції. Згідно з даними SРC, під час пандемії (i до 31 березня) загальне число користувачів цього додатка досягло 1,39 мільйона, й тільки в березні було зареєстровано 390000 нових користувачів, що на 86,78 відсотка більше в порівнянні з лютим [16].

Як зазначалося вище, пандемія змінила порядок роботи китайських судів під час глобальної кризи в галузі охорони здоров' я, та китайська судова система відреагувала на ці проблеми шляхом подальшого заохочення онлайнових судових процесів, тим самим зводячи до мінімуму збої в роботі й зберігаючи право на доступ до судів. Але ці підходи викликають стурбованість. Наприклад, через бюджетні проблеми деякі місцеві суди відстали в плані інфраструктури, й вони не змогли надати «ефективні» онлайнові послуги, як це очікувалося. У зв'язку із цим виникає питання про те, чи користуються всі в Китаї рівним доступом до правосуддя [17]. Аналогічна проблема нерівномірності також посилила «цифровий розрив», який існує між міськими й сільськими районами, а також між старшим і молодим поколіннями. Наприклад, Управління кіберпростору Китаю відзначило, що станом на березень 2020 року в країні налічувалося 496 мільйонів осіб (які в основному проживають у віддалених районах і належать до вікової групи 50 років і старше), які не користувалися Інтернетом через неписьменність і з інших причин [18].

Ще одна проблема, пов'язана з технологічними інноваціями, виходить за рамки рівня «доступу» до правосуддя та за своєю суттю має відношення до якості судових послуг. По суті, питання полягає в тому, чи може використання технології та алгоритмів штучного інтелекту в судових системах дати «справедливі» результати. Наприклад, Вищий народний суд Пекіна розробив додаток «Мікросудовий розгляд у Пекінському суді», за допомогою якого користувачі можуть оцінити, чи зможуть вони виграти в 15 видах справ (включаючи роздільне проживання, успадкування, оренду, працевлаштування і так далі) в судовому розгляді, вклавши деяку основну інформацію про суперечки. Потім система буде оцінювати представлені дані разом з іншими факторами, включаючи витрати, потенційний збиток репутації в разі судового розгляду і так далі, й складати рекомендований звіт про те, чи слід користувачам вдаватися до судового розгляду або інших процесів врегулювання суперечок. Незважаючи на свою корисність із боку «освіти» або «інформування» користувачів про основні правові знання, залишається неясним, яким чином надана інформація використову- 
ється та розраховується за допомогою вбудованого алгоритму, й тому достовірність рекомендації сумнівна [19].

На закінчення слід зазначити, що під час прийняття заходів у відповідь на COVID19 різні юрисдикції були змушені гармонізувати конкуруючі права й інтереси, включаючи право на найвищий досяжний рівень здоров'я та право на доступ до правосуддя. У деяких правових системах наявність варіантів ODR в поєднанні із швидким переходом на відеоконференції означало, що затримки в цих правових системах були не такими значними. У тих правових системах, де вже існують онлайнові суди, які можуть містити ODR, оцифровку й онлайнові варіанти слухань (наприклад, у Китаї), такі варіанти стали більш широко використовуватися. Однак у деяких місцях застарілі судові системи й відсутність розвиненої системи ODR i ADR означають, що співмірні й розумні відповіді неможливі.

У судах, де технологія була доступна й придатна для використання, суддям не завжди надавалась підтримка для виконання їх ролі в режимі онлайн. Це вимагає відповідної підготовки співробітників судових органів із тим, щоб вони могли належним чином використовувати ці технології та проводити слухання без збоїв [20]. Суддям, можливо, також буде потрібно зрозуміти, які проблеми виникають у зв' язку з новими технологіями та яким чином надавати підтримку більш вразливим учасникам судових процесів, в яких можуть виникнути особливі проблеми 3 доступом до технологій та їх використанням (включаючи підтримку доступу до юридичних консультацій i безкоштовну допомогу перекладача в тих випадках, коли особа не може розуміти мову суду або говорити на ньому).

Як вже говорилося, термін «доступ до правосуддя» містить поняття про те, що доступ до судів і суддів буде надаватися без невиправданої затримки. Для того щоб відреагувати на можливий «судовий бум» в постпандемічну епоху, судам у всьому світі необхідно терміново розробити відповідні стратегії. Крім широкого використання технологій для підтримки судових послуг, для юрисдикцій було б доцільно скоротити затримки шляхом подальшого заохочення громадян до участі в процесах альтернативного розв' язання спорів (ADR) замість проведення традиційних судових розглядів у судах.

Хоча все ще ведуться деякі дискусії про те, чи можуть процеси ADR приводити до «справедливих» результатів так само, як традиційні судові процеси [21], деякі країни (включаючи Канаду) вже закликали людей розглянути питання про ADR, щоб уникнути значних затримок і витрат [22]. Цьому є чималі переваги, оскільки використання технологій набагато ширше поширене в рамках ADR i ODR. Крім того, більшість процесів ADR забезпечують більшу гнучкість у порівнянні з традиційними судовими слуханнями й можуть бути більш економічними й ефективними з боку витрат. Уже давно стало ясно, що змагальні моделі правосуддя, що віддають перевагу традиційним судовим системам, застаріли. У зв'язку із цим пропонується, що ADR i ODR можуть забезпечити значні переваги й вигоди в цьому новому світі, особливо як засіб реагування на ймовірне зростання числа суперечок, пов' язаних з охороною здоров'я [23].

Кілька коментаторів прогнозують, що цунамі суперечок, ймовірно, відбудеться в постпандемічний період, уважно стежачи за «хвилями» інфекції, та є деякі свідчення того, що це вже відбувається [24]. Наприклад, у США вже зросла кількість спорів про медичне страхування та суперечок, пов'язаних із медичним обслуговуванням, можливо, у зв' язку з наявною раніше нерівністю в області охорони здоров'я, такою як відсутність безкоштовної системи державної охорони здоров' я або адекватного страхового покриття. Хоча ступінь, в якій така нерівність корелює зі збільшенням кількості позовів, неясна, вартість ліків та охорони здоров' я в США, як стверджується, є однією з основних 
причин для подачі позовів про особисте банкрутство. У нинішніх умовах це ще більше посилюється історичним рівнем безробіття у світі COVID-19 і ситуацією з працівниками, хто втратив медичну страховку через своїх роботодавців. У разі, якщо вони потребують стаціонарного лікування чи догляду, існує ризик того, що вони можуть зіткнутися зі значними економічними труднощами й будуть змушені подати заяву про банкрутство або, в разі необхідності, шукати альтернативний варіант дій у рамках закону.

Висновки. Нинішні масштаби кризи в галузі суспільної охорони здоров'я зажадали від країн розробки новаторських відповідних заходів щодо захисту права людей на здоров'я шляхом встановлення правил соціального дистанціювання під час одночасного забезпечення поваги інших прав людини, включаючи доступ до судових послуг і правосуддя в більш широкому сенсі. Суди були змушені швидко адаптуватися до цієї нової ситуації, та в багатьох країнах для «підтримки» роботи судів і процесів розв’ язання спорів використовувалися більш сучасні технології (такі як Інтернет, штучний інтелект і так далі). Незважаючи на переваги надання більш широкого доступу до правосуддя, зумовлені технологічною інновацією, існують побоювання з приводу використання таких технологій у системі правосуддя, в тому числі з приводу того, як захистити права вразливих соціальних груп і впоратися з порушеннями правосуддя, викликаними деякими нововведеннями. Крім того, необхідно, щоб судді мали доступ до підтримки або ресурсів для продовження своєї роботи в цифровий час, що ускладнюється глобальною кризою в галузі охорони здоров'я. Саскінд раніше відзначав, що ми повинні вирішувати, чи є суд місцем або послугою, і це питання зараз як ніколи актуальне [25]. Напередодні постпандемічного періоду, ймовірно, відбудеться бум спорів, пов'язаних із COVID-19, i, можливо, державам необхідно буде розглянути, крім введення спеціального законодавства про імунітет від відповідальності й медичної недбалості, підходи до ADR і ODR, а також технологічні інновації для забезпечення доступу людей до послуг правосуддя, особливо в суперечках, пов' язаних із COVID-19.

\section{Список використаних джерел:}

1. Cooper A. Coronavirus prompts surge in number of people seeking bail. The Age. 2020 May 10. URL: https://www.theage.com.au/national/victoria/coronavirus-promptssurge-in-number-of-people- seekingbail-20200508-p54r4g.html.

2. Sourdin T, Zeleznikow J. Courts, Mediation and COVID-19. Australian Business Law Review Forthcoming. 2020. URL: https://papers.ssrn.com/sol3/papers.cfm?abstract_ $\mathrm{id}=359591$.

3. Dyess C. The Coming Tsunami of Employment-Related COVID-19Litigation. New York Law Journal. 2020, April. URL: https://www.law.com/newyorklawjournal/2020/04/21/ the-coming-tsunami-ofemployment-related-covid-19-litigation/?slreturn=20200519091735.

4. Kirby M. The Future of Courts - Do They Have One? Journal of Law, Information and Science. 1998. No. 9 (2). P. 141.

5. Sourdin T, Judges, Technology and AI, Edward Elgar, Forthcoming 2021. URL: https:/ / www.cyberjustice.ca/en/2020/10/29/web-conference-reimagining-justice-with-ai-technology/.

6. Сакара Н.Ю. Проблема доступності правосуддя у цивільних справах : монографія. Харків : Право, 2010. 256 с.

7. Цувіна Т.А. Право на суд у цивільному судочинстві : монографія ; Нац. юрид. ун-т ім. Ярослава Мудрого. Харків : Слово, 2015. 281 с.

8. Law360 Staff. Coronavirus: The Latest EU Court Closures And Restrictions. 2020 Jun 23. URL: https://www.law360.com/articles/1253873/coronavirus-the-latest-eu-court-closuresandrestrictions. 
9. Dawuni J. The Gendered Face of COVID-19: Women and Access to Justice. 2020. URL: https://www.unodc.org/dohadeclaration/en/news/2020/04/gendered-face-of-covid19women-and- accessto-justice.html.

10. Supreme People's Court Work Report. Addressed to the National People's Congress by Chief Justice Qiang Zhou. 2020 May 25. URL: http://www.court.gov.cn/zixunxiangqing-231301.html.

11. Chief Justice Zhanguo Li. 2018 January 27. URL: http://www.zjsfgkw.cn/ art/2018/2/12/art_420_405.html.

12. Gao S. Summary of Innovative Practice of Internet Judiciary during the Pandemic. People's Court Newspaper. 2020 Mar 12. URL: http://rmfyb.chinacourt.org/paper/ html/2020-03/12/content_165990.htm.

13. Suprem People's Court, Opinion on Accelerating the Building of Smart Court. April, 2017. URL: http:/ / gongbao.court.gov.cn/Details/5dec527431cdc22b72163b49fc0284.html.

14. Supreme People's Court Work Report. Addressed to the National People's Congress by Chief Justice Qiang Zhou. 2016 March 13. URL: http:/ / www.court.gov.cn/zixun-xiangqing-82592.html.

15. Supreme People's Court. Chinese Courts and the Internet Judiciary. 2019 December 4. URL: http:/ / english.court.gov.cn/pdf/ChineseCourtsandInternetJudiciary.pdf.

16. Sun H. Judicial Services at Hand. People's Court Newspaper. 2020 May 7. URL: http:/ /rmfyb.chinacourt.org/paper/html/2020-05/07/content_167769.htm.

17. Wu T, Chen M. The Building of Smart Court - Value and Design. Social Sciences. 2019. No. 5. P. 106-107. See also: Lou B. Informationalisation of People's Courts: Reflections and Prospects. Journal of China Three Gorges University. 2017. No. 2. P. 75-81.

18. Cyberspace Administration of China. The 45th China Statistical Report on Internet Development. 2020 April 28. URL: http://www.cac.gov.cn/2020-04/2 7/c_1589535470378587.htm.

19. Xu J. Jurisprudential Reflections on Smart Court. Law Science. 2017. No. 3. P. 59-63.

20. McNamara DM. Building a collaborative approach to policing in an age of disability human rights law. Journal of Psychiatric and Mental Health Nursing Forthcoming. 2020. URL: https:// onlinelibrary.wiley.com/doi/full/10.1111/jpm.12609.

21. Sourdin T. A Broader View of Justice? Resolving Civil Disputes / M. Legg. LexisNexis Australia. 2016. P 19-36.

22. Kramer X. Access to justice in times of corona. Conflict of Laws. 2020 Apr 7. URL: https:/ / conflictoflaws.net/2020/access-to-justice-in-times-of-corona/.

23. Balcerzak G.A, Leonhardt K.K. Alternative Dispute Resolution in Healthcare. Patient Safety and Quality Healthcare. 2008. P. 44-48.

24. Dentons Rodyk. Legal issues arising from the effect of the COVID-19 pandemic on healthcare infrastructure. 2020 Apr 27. URL: https://dentons.rodyk.com/en/insights/ alerts / 2020/april/27/legal-issues-arising-from-the-effect-of-the-covid-19pandemic-onhealthcare-infrastructure.

25. Susskind R. Online Courts and the Future of Justice. Oxford: Oxford University Press, 2019. 398 p. 
УДК 346.9(045)

DOI https:// doi.org/10.32850/LB2414-4207.2020.14.13

\title{
ГОСПОДАРСЬКІ САНКЦІЇ ЯК ПРАВОВИЙ ЗАСІБ ВІДПОВІДАЛЬНОСТІ У СФЕРІ ГОСПОДАРЮВАННЯ
}

\author{
Моргунова Тетяна Іванівна, \\ кандидат технічних наук, доцент, \\ доцент кафедри професійних та \\ спеціальних дисциплін \\ (Херсонський факультет \\ Одеського державного університету \\ внутрішніх справ, \\ м. Херсон, Україна)
}

Стаття присвячена науковому дослідженню господарських санкцій як правовому засобу відповідальності у сфері господарювання. У статті визначено види господарських санкцій, передбачені Господарським кодексом України, а також проаналізовано підстави та порядок їх застосування. Встановлено, що господарські санкції - це передбачені законом заходи впливу на правопорушника у сфері господарювання, внаслідок застосування яких для нього настають несприятливі економічні та / або правові наслідки. Розкрито, що підставою господарсько-правової відповідальності учасника господарських відносин є вчинене ним правопорушення у сфері господарювання. Досліджено нормативно-правові акти, які розкривають суть цього поняття та його ознаки. Визначено основну мету застосування господарських санкцій. Встановлено, що у сфері господарювання застосовуються такі види господарських санкцій, як відшкодування збитків, штрафні, оперативно-господарські й адміністративно-господарські санкції. Проаналізовано строки, протягом яких застосовуються господарські санкції.

Встановлено, що учасник господарських відносин, який порушив господарське зобов'язання або установлені вимоги щодо здійснення господарської діяльності, повинен відшкодувати завдані цим збитки суб'єкту, права або законні інтереси якого порушено. Визначено, що штрафними санкціями визнаються господарські санкції у вигляді грошової суми (неустойки, штрафу, пені), яку учасник господарських відносин зобов'язаний сплатити у разі порушення ним правил здійснення господарської діяльності, невиконання або неналежного виконання господарського зобов'язання. Оперативно-господарські санкції - це заходи оперативного впливу на правопорушника 3 метою припинення або попередження повторення порушень зобов'язання, що використовуються самими сторонами зобов'язання в односторонньому порядку.

Ключові слова: господарські санкції, відшкодування збитків, штрафні санкції, оперативно-господарські санкції та адміністративно-господарські санкції. 


\title{
ECONOMIC SANCTIONS AS A LEGAL MEANS OF LIABILITY IN THE SPHERE OF MANAGEMENT
}

\author{
Morhunova Tetiana Ivanivna, \\ Candidate of Technical Sciences, \\ Associate Professor, \\ Associate Professor at the Chair of \\ Professional and Special Disciplines \\ (Kherson Faculty of the Odesa State \\ University of Internal affairs, \\ Kherson, Ukraine)
}

The article is devoted to the scientific study of economic sanctions as a legal means of liability in the field of management. The article identifies the types of economic sanctions provided by the Commercial Code of Ukraine, as well as analyzes the grounds and procedure for their application. It has been established that economic sanctions are measures provided by law to influence the offender in the field of management, as a result of which adverse economic and / or legal consequences occur for him. It is revealed that the basis of economic and legal liability of a participant in economic relations is an offense committed by him in the field of management. The normative-legal acts which reveal the essence of this concept and its signs are investigated. The main purpose of application of economic sanctions is defined. It is established that in the field of management such types of economic sanctions as compensation of losses are applied; penalties; operational and economic sanctions and administrative and economic sanctions. The terms during which economic sanctions are applied are analyzed.

It is established that a participant in economic relations who has violated an economic obligation or established requirements for economic activity, must reimburse the damage caused by the entity whose rights or legitimate interests are violated. It is determined that economic sanctions in the form of a sum of money (penalty, fine, penalty), which the participant of economic relations is obliged to pay in case of violation of the rules of economic activity, non-performance or improper performance of economic obligation. It is revealed that operational and economic sanctions are measures of operational influence on the offender in order to stop or prevent the recurrence of violations of the obligation, which are used by the parties to the obligation unilaterally.

Key words: economic sanctions, damages, penalties, operational and economic sanctions and administrative and economic sanctions.

Вступ. Однією з гарантій розвитку відносин між суб'єктами господарювання виступає наявність інституту відповідальності за вчиненні господарські правопорушення. Чільне місце у системі правових засобів відповідальності посідають господарські санкції, які сьогодні виступають інститутом, що дисциплінує учасників господарських правовідносин і змушує дотримуватися чинного законодавства і взятих на себе зобов' язань, передбачених укладеними договорами.

Крім того, відповідальність у господарських відносинах є важливим засобом утвердження суспільного господарського порядку в економіці, укріплення правових засад господарювання і підвищення на цій основі ефективності суспільного виробництва.

Щодо функціонального відношення, то господарсько-правова відповідальність покликана стимулювати належне виконання господарських та інших зобов'язань, тому що її головною метою є забезпечення правопорядку у сфері економіки, а саме в господарських відносинах. 
Так, ст. 216 Господарського кодексу України (далі - ГК) встановлює, що застосування господарських санкцій повинно гарантувати захист прав і законних інтересів громадян, організацій і держави та забезпечувати правопорядок у сфері господарювання [1]. У цьому зв'язку дослідження питань господарських санкцій виступає як одне з важливих наукових і практичних завдань.

Метою статті $є$ визначення на основі аналізу чинного законодавства України видів господарських санкцій і підстав і порядку їх застосування.

Аналіз останніх досліджень і публікацій. Дослідженням проблем застосування господарських санкцій, у т. ч. аспектам застосування їх окремих видів, присвячені праці таких вчених, як Б. Грек, Т. Малиновська, О. Стороженко, 3. Татькова, Т.Швидка, Н. Шевченко, В. Щербина та ін.

Виклад основного матеріалу. Відповідно до ч. 1 ст. 217 ГК України господарськими санкціями визнаються заходи впливу на правопорушника у сфері господарювання, внаслідок застосування яких для нього настають несприятливі економічні та / або правові наслідки. Насамперед важливим виступає співвідношення понять «господарська відповідальність» і «господарські санкції. У цьому аспекті слід погодитися з Т.М. Малиновською, що господарсько-правову відповідальність можна об'єктивно розуміти як сукупність норм, які встановлюють заходи впливу, що застосовуються до суб'єкта господарювання за вчинене ним правопорушення. Господарсько-правова відповідальність в об'єктивному іiі розумінні тісно переплітається із санкціями. Санкції є зовнішнім відображенням заходів відповідальності. Значення понять «господарсько-правова відповідальність» і «господарські санкції» збігаються лише тоді, коли межі та розмір відповідальності є конкретно визначеними і господарський суд чи сторони спору не можуть вплинути на їх обсяг [2, с. 202]. Господарські санкції, на думку T.M. Малиновської, здебільшого мають відносно визначений характер, що сприяє реалізації принципів еквівалентності та індивідуалізації покарання. Якщо інше не передбачено законом, сторони можуть конкретизувати в договорі відповідальність сторін. Йдеться про господарсько-правову відповідальність у суб'єктивному аспекті. Саме суб'єктивний прояв відповідальності виступає реалізацією охоронних норм. Спочатку сторони договору реалізують об'єктивну відповідальність, адаптуючи ії до договірних інтересів, а потім у разі виникнення спору суд визначає обсяг остаточної господарсько-правової відповідальності з урахуванням договору та складу правопорушення. Санкції як охоронні норми мають більш загальний, вузький характер. У свою чергу, господарсько-правова відповідальність має більш широкий, динамічний характер і спрямована на сходження від загальної, об' єктивної норми до конкретного випадку застосування заходів відповідальності [2, с. 202].

Господарсько-правова відповідальність, будучи багатоплановим поняттям, включає господарські санкції, що утворюють відповідальність у нормативному розумінні цього поняття. Зміст санкцій визначає форму відповідальності та характер наслідків, які настають для правопорушника, проте особливості виконання обов' язку, що становить зміст відповідальності, перебувають поза межами дії санкцій. Тобто господарська відповідальність співвідноситься з господарськими санкціями як загальне та спеціальне.

Господарські санкції застосовуються у встановленому законом порядку за ініціативою учасників господарських відносин, а адміністративно-господарські санкції уповноваженими органами державної влади або органами місцевого самоврядування.

Підставою господарсько-правової відповідальності учасника господарських відносин є вчинене ним правопорушення у сфері господарювання.

Щодо строків застосування господарських санкцій, то законодавець у ст. 223 ГК України встановлює, що при реалізації в судовому порядку відповідальності за пра- 
вопорушення у сфері господарювання застосовуються загальний і скорочені строки позовної давності, передбачені Цивільним кодексом України [3], якщо інші строки не встановлено ГК України. Стосовно строків застосування адміністративно-господарських санкцій до суб' єктів господарювання, то вони встановлені ст. 250 ГК України [1].

Аналіз ст. 217 ГК України дозволяє зробити висновок, що у сфері господарювання застосовуються такі види господарських санкцій, як відшкодування збитків, штрафні, оперативно-господарські й адміністративно-господарські санкції.

Доцільним буде охарактеризувати окремо кожен вид господарських санкцій.

Відшкодування збитків. Відповідно до ст. 224 ГК України учасник господарських відносин, котрий порушив господарське зобов'язання або установлені вимоги щодо здійснення господарської діяльності, повинен відшкодувати завдані цим збитки суб'єкту, права або законні інтереси якого порушено.

Під збитками розуміються витрати, зроблені управненою стороною, втрата або пошкодження ії майна, а також не одержані нею доходи, які управнена сторона одержала б у разі належного виконання зобов'язання або додержання правил здійснення господарської діяльності другою стороною.

Такий вид господарських санкцій виступає гарантією того, що суб'єкт господарювання у разі порушення зобов'язання стороною має передбачену законом можливість на відшкодування шкоди, завданої його невиконанням. Це викликано тим, що наслідки невиконання зобов'язання можуть призвести до різних збитків, і суб'єкт, права якого порушено, має можливість захисту своїх прав.

Крім того, законодавець у ст. 225 ГК України чітко встановлює, що входить до складу збитків, які підлягають відшкодуванню особою, котра допустила господарське правопорушення. До них належать: вартість втраченого, пошкодженого або знищеного майна, визначена відповідно до вимог законодавства; додаткові витрати (штрафні санкції, сплачені іншим суб'єктам, вартість додаткових робіт, додатково витрачених матеріалів тощо), понесені стороною, яка зазнала збитків внаслідок порушення зобов'язання другою стороною; неодержаний прибуток (втрачена вигода), на який сторона, що зазнала збитків, мала право розраховувати у разі належного виконання зобов' язання другою стороною; матеріальна компенсація моральної шкоди у випадках, передбачених законом [1].

При визначенні розміру збитків, якщо інше не передбачено законом або договором, враховуються ціни, що існували за місцем виконання зобов' язання на день задоволення боржником у добровільному порядку вимоги сторони, яка зазнала збитків, а у разі, якщо вимогу не задоволено у добровільному порядку, - на день подання до суду відповідного позову про стягнення збитків.

Щодо порядку й умов застосування відшкодування шкоди, то відповідно до ст. 226 ГК України учасник господарських відносин, котрий вчинив господарське правопорушення, зобов' язаний вжити необхідних заходів щодо запобігання збиткам у господарській сфері інших учасників господарських відносин або щодо зменшення ïx розміру; якщо збитків завдано іншим суб'єктам - то відшкодувати на вимогу цих суб'єктів збитки у добровільному порядку в повному обсязі, якщо законом або договором сторін не передбачено відшкодування збитків в іншому обсязі.

Таким чином, відшкодування шкоди - це вид господарських санкцій, що полягають у відшкодуванні збитків суб'єкту, права або законні інтереси якого порушено, стороною, яка порушила зобов' язання.

Штрафні санкції передбачені ст. 230 ГК України. Так, штрафними санкціями визнаються господарські санкції у вигляді грошової суми (неустойки, штрафу, пені), яку учасник господарських відносин зобов'язаний сплатити у разі порушення ним пра- 
вил здійснення господарської діяльності, невиконання або неналежного виконання господарського зобов' язання.

Цілком впевнено можна стверджувати, що штрафні санкції виступають як спосіб забезпечення виконання зобов'язання суб'єктом господарювання, але законодавець визначає у ст. 232 ГК України, що, якщо за невиконання або неналежне виконання зобов'язання встановлено штрафні санкції, то збитки відшкодовуються в частині, не покритій цими санкціями.

Розмір штрафних санкцій залежить від суб'єктного складу учасників господарських правовідносин. Так, якщо одна сторона є суб'єктом господарювання і належить до державного сектора економіки, або порушення пов'язане з виконанням державного контракту, або виконання зобов' язання фінансується за рахунок Державного бюджету України чи за рахунок державного кредиту, штрафні санкції застосовуються за встановленими законом розмірами. Якщо розмір штрафних санкцій законом не визначено, санкції застосовуються в розмірі, передбаченому договором. Розмір санкцій може бути встановлено договором у відсотковому відношенні до суми невиконаної частини зобов' язання або у певній, визначеній грошовій сумі, або у відсотковому відношенні до суми зобов' язання незалежно від ступеня його виконання, або у кратному розмірі до вартості товарів (робіт, послуг).

Тобто сторони господарських відносин можуть самостійно встановлювати розміри штрафних санкцій, крім тих випадків, коли вони прямо передбачені законом.

Крім того, сплата штрафних санкцій за невиконання або неналежне виконання господарського зобов' язання не звільняє боржника від виконання зобов'язання в натурі. Навіть у разі сплати штрафних санкцій зобов'язальні правовідносини не припиняються, оскільки боржник повинен виконати зобов'язання відповідно до укладеного договору.

Оперативно-господарсъкі санкиії. Згідно зі ст. 235 ГК України оперативно-господарські санкції - це заходи оперативного впливу на правопорушника з метою припинення або попередження повторення порушень зобов' язання, що використовуються самими сторонами зобов' язання в односторонньому порядку.

У господарських договорах сторони можуть передбачати використання таких видів оперативно-господарських санкцій, як:

- одностороння відмова від виконання свого зобов'язання управненою стороною зі звільненням іï від відповідальності за це у разі порушення зобов'язання другою стороною;

- відмова управненої сторони зобов'язання від прийняття подальшого виконання зобов'язання, порушеного другою стороною, або повернення в односторонньому порядку виконаного кредитором за зобов'язанням (списання з рахунку боржника в безакцептному порядку коштів, сплачених за неякісну продукцію, тощо);

- встановлення в односторонньому порядку на майбутнє додаткових гарантій належного виконання зобов'язань стороною, яка порушила зобов'язання: зміна порядку оплати продукції (робіт, послуг), переведення платника на попередню оплату продукції (робіт, послуг) або на оплату після перевірки їх якості тощо;

- відмова від встановлення на майбутнє господарських відносин зі стороною, яка порушує зобов' язання.

На думку О.В. Кологойди, оперативно-господарським санкціям притаманний ряд ознак, які залежать від конкретного виду господарських відносин. Так, якщо це фондові відносини, то їхніми ознаками є організаційний характер, спрямованість на зміну договірного правовідношення, застосування незалежно від вини порушника договірного зобов'язання, в односторонньому, несудовому порядку, без попереднього 
пред'явлення претензії порушникові та без звернення до юрисдикційного органу. Видами оперативно-господарських санкцій у досліджуваних відносинах є: тимчасове зупинення дії договору, одностороннє розірвання договору, припинення надання послуг, безспірне договірне списання коштів із рахунку або прав учасника клірингу, невиконання / зупинення виконання договірних зобов' язань [4, с. 92].

М.Ю. Потоцький, досліджуючи застосування оперативно-господарських санкцій у сфері інтелектуальної власності, зазначає, що з особливою гостротою необхідність таких санкцій відчувається у сфері інтелектуальної власності, де захист прав має бути швидким та ефективним, оскільки порушення, пов'язані 3 нематеріальними об'єктами, значно ускладнюють відновлення становища, що існувало до порушення. На відміну від штрафних санкцій, які можуть бути передбачені як у законі, так і в договорі, оперативно-господарські санкції можуть бути передбачені тільки в договорі. Однією з важливих особливостей оперативно-господарських санкцій є те, що вони можуть застосовуватися незалежно від відсутності чи наявності вини суб'єкта господарювання [5, с. 152].

Тобто оперативно-господарські санкції виконують запобіжну функцію та мають на меті припинення порушення виконання господарських обов' язків і недопущення або мінімізацію їх негативних наслідків.

Слід погодися з М.Ю. Потоцьким, що наявність такого механізму у законодавстві, як оперативно-господарські санкції, забезпечує економію часу та коштів, а також дозволяє оперативно припинити чи навіть не допустити несприятливі наслідки від протиправної поведінки контрагентів.

Підставою для застосування оперативно-господарських санкцій $є$ факт порушення господарського зобов'язання другою стороною. Оперативно-господарські санкції застосовуються стороною, яка потерпіла від правопорушення, у позасудовому порядку та без попереднього пред'явлення претензії порушнику зобов' язання. Сторони можуть визначити порядок застосування конкретних оперативно-господарських санкцій договором. У разі незгоди із застосуванням оперативно-господарської санкції заінтересована сторона може звернутися до суду із заявою про скасування такої санкції та відшкодування збитків, завданих ії застосуванням.

Крім того, оперативно-господарські санкції можуть застосовуватися одночасно із відшкодуванням збитків і стягненням штрафних санкцій.

Адміністративно-господарські санкиії. За порушення встановлених законодавчими актами правил здійснення господарської діяльності до суб'єктів господарювання можуть бути застосовані уповноваженими органами державної влади або органами місцевого самоврядування адміністративно-господарські санкції, тобто заходи організаційно-правового або майнового характеру, спрямовані на припинення правопорушення суб'єкта господарювання та ліквідацію його наслідків.

Слід погодитися 3 Н.В. Добрянською, що адміністративно-господарські санкції за своїми матеріальними та процесуальними властивостями мають загальні ознаки адміністративної відповідальності, а саме: не мають компенсаційного характеру, не відновлюють початкового майнового стану, їх стягнення здійснюються не на користь іншої сторони або особи господарсько-правових відносин. Адміністративно-господарські санкції за своїми матеріальними та процесуальними властивостями мають загальні риси з адміністративного відповідальністю. Логічна структура норм адміністративно-господарських санкцій допускає наявність гіпотези, диспозиції та санкції, які за змістом тотожні адміністративно-деліктним нормам із їх імперативним, державно-владним характером. Одним із моментів, який дає змогу стверджувати, що адміністративно-господарські санкції є одним із різновидів адміністративних санкцій, $є$ те, 
що ГК України розмежовує адміністративно-господарські та інші види господарських санкцій за критерієм суб'єкта застосування цих санкцій [6, с. 92].

Видами адміністративно-господарських санкцій є: вилучення прибутку (доходу); адміністративно-господарський штраф; стягнення зборів (обов'язкових платежів); застосування антидемпінгових заходів; припинення експортно-імпортних операцій; застосування індивідуального режиму ліцензування на умовах і в порядку, визначених законом; зупинення дії ліцензії (патенту) на здійснення суб'єктом господарювання певних видів господарської діяльності; анулювання ліцензії (патенту) на здійснення суб'єктом господарювання окремих видів господарської діяльності; обмеження або зупинення діяльності суб'єкта господарювання; ліквідація суб'єкта господарювання; інші адміністративно-господарські санкції, встановлені законом [1].

Н.Ю. Кантор зазначає, що належна законодавча форма та застосування адміністративно-господарських санкцій у передбаченому законом порядку є необхідною правовою гарантією реалізації прав і законних інтересів не лише суб'єктів господарювання, а й Української держави загалом. Застосування адміністративно-господарських санкцій має сприйматися не з позицій репресивних, а з погляду забезпечення умов та усунення перешкод у формі порушень загальнообов' язкових правил, які стають на шляху якісного розвитку економічних відносин в Україні [7, с. 90].

Адміністративно-господарським санкціям притаманні такі ознаки:

- адміністративно-господарські санкції застосовуються до суб'єктів господарювання;

- адміністративно-господарські санкції за змістом є заходами організаційно-правового характеру або майнового;

- метою застосування адміністративно-господарських санкцій є припинення правопорушення суб'єкта господарювання та ліквідація його наслідків;

- адміністративно-господарські санкції застосовуються уповноваженими органами державної влади або органами місцевого самоврядування;

- підставою застосування адміністративно-господарських санкцій є порушення встановлених законодавчими актами правил здійснення господарської діяльності.

Також слушною є думка I.О. Віхрової, яка наголошує, що однією з важливих ознак адміністративно-господарських санкцій є те, що вони встановлюються виключно законами, а не підзаконними актами чи договором. Виключно законами визначаються й види цих санкцій, умови та порядок їх застосування [8, с. 152].

Висновки. Враховуючи вищезазначене, можна дійти висновку, що господарські санкції - це передбачені законом заходи впливу на правопорушника у сфері господарювання, внаслідок застосування яких для нього настають несприятливі економічні та / або правові наслідки. Тобто господарські санкції дійсно існують як правовий засіб відповідальності у сфері господарювання.

Що стосується підстав застосування господарських санкцій, то вони застосовуються у разі вчинення правопорушення суб'єктом господарювання.

Видами господарських санкцій $є$ відшкодування збитків, штрафні, оперативно-господарські й адміністративно-господарські санкції. Кожен із видів господарських санкцій має свої специфічні ознаки та порядок застосування, що може бути предметом окремого дослідження в майбутньому.

\section{Список використаних джерел:}

1. Господарський кодекс України від 16 січня 2003 р. № 436-IV. Відомості Верховної Ради України. 2003. № 18. Ст. 144.

2. Малиновська Т.М. Співвідношення понять «господарсько-правова відповідальність» та «господарсько-правові санкції». Право і Безпека. 2011. № 4. С. 200-202. URL: http://nbuv.gov.ua/UJRN/Pib_2011_4_46. 
3. Цивільний кодекс України від 16 січня 2003 р. № 436-IV. Відомості Верховної Ради Украӥни. 2003. № 40-44. Ст. 356.

4. Кологойда О.В. Оперативно-господарські санкції у фондових договірних правовідносинах. Науковий вісник Ужгородського національного університету. Серія : Право. 2016. Вип. 39 (1). С. 89-92. URL: http://nbuv.gov.ua/UJRN/nvuzhpr_2016_39(1)_23.

5. Потоцький М.Ю. Оперативно-господарські санкції у сфері інтелектуальної власності. Європейсъкі перспективи. 2013. № 8. С. 147-153. URL: http://nbuv.gov.ua/ UJRN/evpe_2013_8_30.

6. Добрянська Н.В. Адміністративно-господарські санкції та їх правове регулювання. Юридична наука. 2015. № 11. С. 91-98. URL: http://nbuv.gov.ua/UJRN/ jnn_2015_11_12.

7. Кантор Н.Ю. Адміністративно-господарські санкції як гарантії реалізації та захисту економічних інтересів держави. Науковий вісник Ужгородського національного університету. Серія : Право. 2015. Вип. 34 (2). С. 87-90. URL: http://nbuv.gov.ua/UJRN/ nvuzhpr_2015_34(2)_24.

8. Віхрова I.О. Адміністративно-господарські санкції як заходи господарсько-правової відповідальності. Часопис Київського університету права. 2015. № 2. С. 151-155. URL: http://nbuv.gov.ua/UJRN/Chkup_2015_2_37. 
УДК 349.2;347.99

DOI https:// doi.org/10.32850/LB2414-4207.2020.14.14

\title{
ЗАСАДИ ЗАКОННОСТІ ЗВІЛЬНЕННЯ ПРАЦІВНИКІВ ЗА ІНІЦІАТИВИ РОБОТОДАВЦЯ ${ }^{1}$
}

\author{
Погорєлова Олександра Сергіївна, \\ кандидат юридичних наук, \\ асистент кафедри трудового права та \\ права соціального забезпечення \\ (Київський національний університет \\ імені Тараса Шевченка, \\ м. Київ, Україна)
}

Стаття присвячена питанням правового захисту прав працівників при їх звільненні з ініціативи роботодавця й аналізу основних міжнародних трудових стандартів із визначеного питання задля здійснення пропозицій щодо вдосконалення чинного трудового законодавства 3 питань припинення трудових правовідносин з ініціативи роботодавця. Основними засадами Конвенції МОП № 158 щодо захисту від незаконного звільнення працівників, які є відповідно і критеріями законності звільнення працівників, є наявність справедливої та обгрунтованої причини для звільнення працівників і додержання процедурних моментів припинення трудових правовідносин 3 ініціативи роботодавця. Автором статті проаналізовано стан відповідності національного законодавства України міжнародним трудовим стандартам, розглянуто зарубіжний досвід врегулювання питань стосовно законності звільнення працівників. У статті зроблено висновок про невідповідність такої причини для звільнення, як звільнення посадових осіб, визначеної п. 5 ч. 1 ст. 41 КЗпП України, умовам справедливості причин для звільнення працівників з ініціативи роботодавця, одночасно зроблено висновок щодо необхідності включення до чинного трудового законодавства причин, які не можуть вважатися законними причинами для звільнення задля забезпечення захисту незахищених категорій працівників. Крім того, статтею розглянуто питання щодо необхідності попередження працівників про майбутнє звільнення, визначено необхідність щодо диференціації термінів попередження при звільненні залежно від стажу роботи працівника на підприємстві, необхідність встановлення додаткової відпустки під час терміну попередження для можливості забезпечення зайнятості після звільнення, а також необхідність встановлення різного розміру вихідної допомоги працівникам залежно від стажу роботи на підприємстві, що додатково може забезпечити захист зайнятості.

Ключові слова: законність звільнення, Конвенція МОП № 158, справедливі підстави звільнення, попередження при звільненні, вихідна допомога.

\footnotetext{
${ }^{1}$ Наукове дослідження проведено в рамках держбюджетної теми № 19БФ042-01М «Соціально-правові засади збереження та розвитку трудового потенціалу України»
} 


\title{
PRINCIPLES OF LEGALITY OF DISMISSAL OF EMPLOYEES AT THE INITIATIVE OF THE EMPLOYER
}

\author{
Pohorielova Oleksandra Serhiivna, \\ Candidate of Law Sciences, \\ Assistant at the Department of Labour \\ Law and Social Security Law \\ (Taras Shevchenko National \\ University of Kyiv, \\ Kyiv, Ukraine)
}

The article is devoted to the issues of legal protection of the employees' rights when they are terminated at the initiative of the employer, and analysis of the mentioned question to implement proposals regarding improving current labor legislation regarding the termination of employment at the initiative of the employer.

The main principles of the Convention of International Labor Organization № 158, regarding protection from illegal termination of employees, are correspondently the standards of legality of employees' termination, and are the fair and justified reasons to terminate the employees and following the procedure of termination at the initiative of the employer. The author had analyzed the state of compliance of the national legislation of Ukraine with international labor standards. Also, the foreign experience of settlement of questions concerning legality of employees' termination had been considered. It is concluded that such the reason of termination, as officials' termination, defined in clause 5 of part 1 of Article 41 of the Labor Code of Ukraine, does not comply with the conditions of justified reasons of termination at the initiative of the employer. Simultaneously it is concluded that the current labor legislation shall include the reasons, which cannot be considered as legal reasons of termination to ensure the protection of unprotected categories of employees. Moreover, the issue that the employees shall be noticed about future termination was considered. Additionally, in the article, the need to differentiate terms of the notice period of termination depending on the length of service of the employee at the enterprise, and the need of establishing additional leave during the notice period to provide employment after termination, was identified. Also, the article determinates the need of establishing different levels of severance allowance to employees depending on the length of service at the enterprise, which can further provide employment protection.

Key words: legality of termination, ILO Convention № 158, justified grounds of termination, notice period of termination, severance allowance.

Вступ. Основою функціонування будь-якого підприємства, установи й організації зокрема та держави загалом є працівники. Без використання праці працівників не буде існувати належного функціонування підприємств, досягнення цілей їх діяльності й економічного зростання, а відповідно можливості економічного розвитку країни, який першочергово залежить від високоефективної діяльності людини (працівника). Праця людини може бути продуктивною, із досягненням найвищих результатів в роботі, лише при належному гарантуванні працівникам здійснення їх прав в процесі здійснення трудової діяльності. Кодексом законів про працю України, згідно ст. 5-1, визначено однією з основних гарантій забезпечення права на працю правовий захист працівників від незаконного звільнення та сприяння у збереженні роботи працівників [1], у зв'язку з чим потребується визначення основних засад при врегулюванні питань, що виникають при припиненні трудових правовідносин. 
Питання щодо припинення трудових правовідносин були предметом дослідження більшості науковців у галузі трудового права. Зокрема, питання щодо гарантій прав працівників при припиненні трудових правовідносин розглядалися такими вченими: Н.В. Кохан, Ю.А. Джепа, І.І. Яцкевич, К.Ю. Мельник, А.О. Бабенко, О.С. Вареник, Е.П. Бабенко та ін. Незважаючи на велику кількість наукових праць, недостатньо вивчене додержання принципу законності при припиненні трудових відносин з ініціативи роботодавця. Це питання набуває особливої актуальності у світлі активізації процесів щодо розробки та прийняття нового трудового кодексу Україні, який має враховувати сучасні проблеми врегулювання трудових правовідносин.

Метою иієї статmі є здійснення пропозицій щодо вдосконалення трудового законодавства у сфері припинення трудових правовідносин.

Предметом дослідження є сучасний стан та особливості нормативно-правового регулювання питань щодо припинення трудових правовідносин.

Об'єктом суспільні відносини, що виникають у процесі припинення трудових правовідносин.

Методологія дослідження. В основу методології покладено загальнонауковий діалектичний метод пізнання, а також низку наукових методів. Так, за допомогою догматичного методу у поєднанні з порівняльно-правовим і структурно-логічним, формально-юридичний методом сформульовано пропозиції щодо вдосконалення правових норм із погляду їх відповідності міжнародним стандартам і вироблення нових правових норм для врегулювання визначених питань. Широко застосовані також такі методи, як: аналіз, доказ, судження, аналогія, порівняння, узагальнення та ін.

Основні результати. Сучасне врегулювання трудових правовідносин сьогодні постає перед рядом проблем, які пов'язані із тенденціями розвитку суспільства, зокрема це становлення ринкової економіки та перехід на ринкові принципи господарювання, стрімкий розвиток техніки та новітніх технологій, становлення нової «економіки знань», тобто інтелектуалізація праці [2, с. 27-28]. Поряд із цими факторами виникає тенденція до посилення гнучкості правового регулювання трудових правовідносин, за якою відбувається тяжіння до дерегулювання відносин між працівником і роботодавцем, у зв'язку з чим ключовим фактором у сучасному трудовому законодавстві має стати забезпечення гнучкості трудових правовідносин [3]. Тяжіння до лібералізації трудового законодавства не обійшло й Україну, яскравим прикладам чого є проект закону України «Про працю» від 28 січня 2019 р. [4], яким було запропоновано відмовитися від переліку причин для звільнення працівників з ініціативи роботодавця та можливості звільнення працівників без будь-якої поважної причини.

Однак, проводячи реформу трудового законодавства, не можна забувати про те, що одним з основних напрямів удосконалення чинного трудового законодавства має бути приведення його у відповідність до міжнародних трудових стандартів [5, с. 126], які мають високий рівень загальності та містять загальні засади та керівні ідеї, що будуть керівними для визначення соціальної політики у сфері трудових правовідносин [6, с. 15]. Основні міжнародні трудові стандарти передбачаються документами Міжнародної організації праці, які є керівними ідеями у формуванні національного законодавства, що регулює трудові правовідносини. Основні стандарти у сфері припинення трудових правовідносин з ініціативи роботодавця визначені Конвенцією МОП № 158 «Про припинення трудових відносин з ініціативи роботодавця» від 22 червня 1982 р., ратифікованою Україною 04 лютого 1994 р., яка була прийнята Міжнародною організацією праці у зв' язку зі стурбованістю міжнародної спільноти із приводу незаконних звільнень працівників.

Основним положенням Конвенції МОП № 158, визначеним ст. 4, є те, що працівники мають бути захищені від необгрунтованого звільнення з ініціативи роботодавця, 
найважливішою гарантією чого є наявність підстави для припинення трудових правовідносин, підстави мають бути справедливими й обгрунтованими та можуть бути визначені як такі, лише якщо пов'язані з певними обставинами: здібностями, поведінкою працівника або виробничою потребою [7]. Це положення Конвенції МОП № 158 відображене у ст. 40, 41 КЗпП України, де визначено основний перелік підстав для звільнення працівників з ініціативи роботодавця [1].

Слід зазначити, що у світіє держави, які вирішили питання звільнення працівників з ініціативи роботодавця дещо іншим шляхом, без запровадження в законі переліку підстав для звільнення. Так, наприклад, у Данії, відомій своїм гнучким регулюванням трудових правовідносин, визначено, що питання щодо звільнення працівників із роботи врегульовується в колективних договорах, і працівники не завжди є належним чином захищені при припиненні трудових правовідносин [8]. У Нідерландах визначено, що працівники з ініціативи роботодавця без їхньої згоди можуть бути звільнені після звернення до страхової компанії або до судових органів із проханням про звільнення працівника із зазначенням «серйозної причини звільнення»; якщо такої згоди надано не буде, роботодавець не має права звільняти працівників. Законодавством США працівників можна звільняти несправедливо та без жодної вагомої причини або навіть із морально несправедливої причини, причини для звільнення можуть бути зазначені лише у трудовому договорі з працівником. Проте реформування законодавства в Свропі, направлене на підсилення гнучкості та загострення уваги на дерегулюванні ринку праці, зокрема щодо питань припинення трудових правовідносин з ініціативи роботодавця, не призводить до зниження безробіття [9, с. 324]. Якщо припинення трудової діяльності не є об'єктивно розумним або соціально прийнятним, не стосується здоров'я або поведінки працівника чи експлуатаційних вимог роботодавця, вважається, що це є зловживання правом, а відповідно, таке звільнення має бути нікчемним [10, с. 34].

3 урахуванням зазначеного, необхідно зазначити, що норма трудового законодавства України щодо припинення трудових правовідносин із посадовими особами, визначена п. 5 ч. 1 ст. 41 КЗпП України, не відповідає вимогам справедливості причини звільнення трудових правовідносин. Така причина трудових правовідносин не визначає жодних підстав для звільнення працівників і жодного порядку звільнення за цією підставою (жодних термінів завчасного сповіщення). Фактично передбачається, що «посадових осіб» можуть звільнити в будь-який час без жодної причини. Крім того, трудовим законодавством не розкрито значення терміна «посадові особи», тобто не визначено, до яких категорій осіб застосовувати цю підставу для звільнення, що на практиці викликає труднощі у правозастосуванні. 3 цього приводу Є.В. Краснов зазначає, що, враховуючи мету внесення такої підстави для звільнення до трудового законодавства (щодо захисту прав інвесторів), необхідно застосовувати ії до керівників господарських товариств або осіб, котрі входять до колегіального виконавчого органу господарського товариства [11]. Ця підстава для звільнення передбачає виплату вихідної допомоги звільненому працівникові у розмірі не менше шестимісячного середнього заробітку, проте МОП підкреслює, що право працівника на вихідну допомогу відрізняється від права працівника щодо звільнення за поважною причиною, і наявність вихідної допомоги та терміну попередження про звільнення не звільняє роботодавця від зазначення причини звільнення працівника. Така причина для звільнення має бути наявна незалежно від інших обставин, має бути обгрунтована та справедлива [10; 31]. 3 огляду на те, що підстава, визначена п. 5 ч.1 ст. 41 КЗпП України, не пов' язана зі здібностями працівника, його станом здоров'я й експлуатаційними вимогами підприємства, установи, організації, припинення повноважень посадових осіб 
$€$ несправедливою причиною звільнення працівника і має бути виключеним із трудового законодавства.

Крім того, необхідно зазначити, що такі звільнення на практиці здебільшого пов' язані зі зміною власників юридичних осіб, передачею корпоративних прав із державного сектору економіки до приватного або передачею (купівлею) корпоративних прав між приватними особами. Здебільшого нові власники з набуттям корпоративних прав виявляють бажання зміни працівників, особливо що стосується керівних посад, призначаючи «своїх працівників». Звільнення у зв’ язку із зміною власника корпоративних прав юридичної особи не є таким, що відповідає вимогам справедливої причини для звільнення. Відповідно до положень Директиви Ради № 2001/23/СС від 12 березня 2001 р. «Про наближення законодавств держав-членів, що стосується охорони прав працівників у випадку передачі підприємств, бізнесових структур або частин підприємств або бізнесових структур» [12], положення якої мають бути імплементовані до українського трудового законодавства, згідно з додатком XL до глави 21 Угоди про асоціацію між Україною з однією сторони, та Європейським Союзом, Свропейським співтовариствам з атомної енергії та їхніми державами-членами, з іншої сторони, від 27 червня 2014 р. [13] визначено гарантію щодо заборони припинення трудових договорів із працівниками у разі зміни власників юридичних осіб. Ця гарантія міститься в Кодексі законів про працю України, ст. 36 якої визначено, що дія трудового договору продовжується у разі зміни власника підприємства, а також у разі його реорганізації, що стосується також і всіх «посадових осіб». Крім того, говорячи про зазначено директиву, слід зазначити, що законом має бути забезпечене гарантування працівникам права на інформацію щодо зміни власника підприємства, установи, організації, а це слід передбачити новим трудовим законодавством [12].

Справедливість причини звільнення також забезпечується, як визначено Конвенцією МОП № 158, переліком підстав, за яких звільнення не може бути здійснено роботодавцем, таких як: членство працівника у профспілці; виконання працівником функцій представника працівників (у минулому чи намір стати представником у майбутньому); факт подання працівником скарги або участь у справі проти роботодавця; раса, колір шкіри, стать, сімейний стан та обов'язки, вагітність, віросповідання, політичні погляди, соціальне походження, національність і перебування у відпустці по материнству [7]. Рекомендація МОП № 166 щодо припинення трудових відносин з ініціативи роботодавця, яка є доповненням до вищезгаданої Конвенції МОП № 158, визначає, що такий перелік підстав, які не можуть бути застосовані для звільнення, може бути доповнено, наприклад, такою причиною, як вік працівника залежно від національних законодавства і практики, що стосуються виходу на пенсію [14]. Основою такого положення є ідея про те, що кожного конкретного працівника має бути оцінено саме через його здібності до праці, які він виявляє у процесі роботи, а не на досягнутому (похилому) віці. У цьому контексті деякі країни мають положення щодо захисту працівників похилого віку від дискримінації та положення щодо заборони звільняти через досягнення працівниками похилого віку [10, с. 55]. Врегулювання цього питання має надзвичайно актуальний характер, враховуючи те, що тенденція старіння населення як у світі загалом, так і в Україні зокрема сприяє підвищенню пенсійного віку, а економічна криза - продовженню трудових правовідносин працівниками після досягнення пенсійного віку. Тому слід визнати, що особи похилого віку потребують додаткового гарантування своїх прав, зокрема при припиненні трудових правовідносин.

Підстави, які не є справедливими причинами для звільнення і за якими не може бути звільнено працівників, потребують включення до трудового законодавства 
України та, як зазначає М.М. Якименко, є підвищенням рівня правового захисту працівників у процесі припинення трудових правовідносин [15, с. 129].

Окрім справедливої причини для звільнення, важливим елементом законності звільнення працівника з ініціативи роботодавця є дотримання процедур припинення трудових правовідносин, які можуть передувати звільненню, та наявність процедур, направлених на оскарження дій роботодавця у разі незаконного звільнення [10, с. 63].

При звільненні працівників важливим процедурним моментом є можливість захисту працівниками своїх прав перед звільненням і заборона припинення трудових відносин із мотивів поведінки працівника, доки працівникові не буде надано можливості захисту проти висунутих звинувачень (ст. 7 Конвенції МОП № 158), що втілюється в українському законодавстві в положенні ст. 149 КЗпП України щодо надання пояснення до застосування дисциплінарних стягнень. Рекомендацією МОП № 166 [14] визначено, що роботодавець має повідомити працівника про рішення щодо майбутнього припинення трудових правовідносин із наданням можливості працівникові отримати письмові пояснення причини звільнення. Також Рекомендація № 166 визначає необхідність консультування із представницькими органами працівників щодо окремих випадків звільнення працівників, що визначено ст. 43 КЗпП України.

Важливим процедурним елементом забезпечення прав працівників при звільненні ïx 3 ініціативи роботодавця є питання, визначені ст. 11 Конвенції МОП № 158 щодо попередження при звільненні, згідно з якою: «Працівник, з яким намічено припинити трудові відносини, має право бути попередженим про це за розумний строк або має право на грошову компенсацію замість попередження, якщо він не вчинив серйозної провини, тобто такої провини, у зв' язку з якою було б недоцільно вимагати від роботодавця продовжувати з ним трудові відносини протягом строку попередження» [7].

У національному законодавстві України передбачається необхідність попередження щодо майбутнього звільнення при вивільненні працівників за 2 місяці до майбутнього звільнення та при звільненні працівників, як таких, що не пройшли випробування, - за три дні до звільнення.

Вимоги щодо необхідності визначення термінів попередження при звільненні також окреслені п. 4 ст. 4 Свропейської соціальної хартії (переглянутої), яка була ратифікована Україною 14 вересня 2006 р. із взяттям виконувати окремі зобов'язання, зокрема зобов' язання, визначені ст. 4. Проте у 2014 р. Європейським комітетом по соціальних правах було визначено, що законодавство України не відповідає вимогам взятих на неї зобов' язань: строки попередження при масовому вивільненні працівників мають бути диференційованими залежно від терміну роботи працівників у роботодавця, тобто цим вищий стаж роботи працівника на підприємстві, тим більший строк попередження має бути при попередженні про звільнення [16]. Так, наприклад, у законодавстві Албанії кожна зі сторін трудового договору має право розірвати трудовий договір під час випробувального терміну, повідомивши іншу сторону про своє звільнення за 5 днів, після випробувального терміну сторони можуть розірвати трудовий договір, здійснивши попередження: за один місяць протягом першого року роботи; за два місяці під час роботи з другого по п'ятий рік роботи; три місяці у разі роботи на підприємстві більше п'яти років [17]. Крім того, щодо терміну попередження при звільненні Рекомендація МОП № 166 визначила необхідність звільнення від роботи працівників протягом терміну попередження для можливості знайти іншу роботу для себе, такий час має бути оплачений [14], що є гарантуванням забезпечення працевлаштування для працівників, які звільняються. Положень щодо оплатної відпустки під час терміну попередження українське законодавство не містить, а це позбавляє працівників можливості пошуку нової 
роботи під час терміну попередження, відвідування співбесід тощо, що є зменшенням трудових прав порівняно з міжнародними стандартами.

Нестабільність трудових правовідносин через звільнення, безперечно, може нанести шкоду здоров'ю працівників. Проте А. Рівз, М. Маккі, Д. Стаклер у своєму дослідженні визначили, що встановлення в законодавстві більших періодів зайнятості може знизити визначені ризики для здоров'я працівників, виходячи з такого: 1) довші періоди попередження знижують відчуття працівників щодо незахищеності та страху перед безробіттям і неможливістю отримати кошти для забезпечення своїх потреб; 2) значні періоди попередження про звільнення надають працівникам можливість для фінансової, психологічної та професіональної адаптації. Також зменшити страх безробіття та втрати прибутку і пов'язаного з цим фінансового напруження може виплата працівникам вихідної допомоги [16].

Вихідна допомога, як визначає Л.В. Золотухіна, «є грошовою виплатою, не пов' язаною з іншими видами розрахунку при звільненні, яка виплачується у зв'язку з розірванням трудового договору на окремих підставах, визначених законом» [19, с. 145]. У Конвенції МОП № 158 визначено, що роботодавець у разі припинення трудових правовідносин зі своєї ініціативи має виплатити працівникові вихідну допомогу, розмір якої має залежати від розміру заробітної плати працівника та кількості стажу роботи на підприємстві, з якого звільняється працівник [7]. Національне законодавство України, хоч і передбачає виплату працівникам вихідної допомоги при звільненні, проте не містить вимог щодо диференціації розміру вихідної допомоги відповідно до стажу роботи працівників. Відсутність в українському законодавстві різниці щодо вихідної допомоги надає відносно високі гарантії для працівників, котрі працювали невеликий проміжок часу на підприємстві, та зменшує гарантії для працівників із високим стажем роботи [20, с. 51].

Висновки. Підсумовуючи наведене, слід зазначити, що задля належного захисту працівників при звільненні за ініціативи роботодавця та визнання такого припинення трудових правовідносин законним має бути дотримано основні вимоги щодо наявності справедливої причини для звільнення працівників і додержання нормативно закріпленої процедури звільнення працівників.

Із зазначено можна зробити висновок, що здебільшого українське законодавство відповідає Конвенції МОП № 158 «Про припинення трудових відносин з ініціативи роботодавця» від 22 червня 1982 р., проте при реформуванні трудового законодавства в Україні мають бути враховані такі моменти:

повинні бути виключені підстави звільнення працівників, які є несправедливими та не пов' язаними зі здібностями, поведінкою працівника або виробничою потребою підприємства, установи, організації, із включенням до національного законодавства причин, що не можуть слугувати підставами для звільнення, для додаткового захисту прав працівників при припиненні трудових правовідносин;

має бути передбачена диференціація строків попередження при звільненні працівників і при виплаті вихідної допомоги залежно від стажу роботи на підприємстві, в установі, організації, встановлено можливість взяття працівниками відпустки для підшукування нової роботи під час попередження їх про майбутнє звільнення.

\section{Список використаних джерел:}

1. Кодекс законів про працю України від 10 грудня 1971 p. URL: https:/ / zakon.rada.gov.ua/laws/main/322-08 (дата звернення: 20.09.2020).

2. Колот А.М. Соціально-трудова сфера: стан відносин, нові виклики, тенденції розвитку : монографія. Київ : КНЕУ, 2010. 251 с. 
3. Thomas Bredgaard. Flexibility and Security in Employment Regulation: What Can Be Learnt from the Danish Case? URL: https:/ / www.researchgate.net/publication/228446703_ Flexibility_and_Security_in_Employment_Regulation_What_Can_Be_Learnt_from_the_ Danish_Case (дата звернення: 20.09.2020).

4. Проект закону України «Про працю» від 28 січня 2019 p. URL: http:/ / search.ligazakon.ua/1_doc2.nsf/link1/JI01112A.html (дата звернення: 20.09.2020).

5. Хуторян Н.М. Напрямки розвитку науки трудового права. Правова держава. Вип. 25. 2014. С. 121-133.

6. Грекова. М.М. Міжнародні трудові стандарти як основа вдосконалення трудового законодавства України : автореф. дис. ... канд. юрид. наук : 12.00.05. Харків, 2009. 20 c.

7. Конвенція МОП № 158 про припинення трудових правовідносин від 22 червня 1982 p. URL: https://zakon.rada.gov.ua/laws/show/993_005\#Text (дата звернення: 20.09.2020).

8. Bjarke Refslund, Stine Rasmussen and Ole HSørensen. Security and labour market flexibility: an alternative view from Denmark. May 2017. URL: https:/ / www.researchgate.net/ profile/Bjarke_Refslund/publication/316923959_Security_and_labour_market_flexibility_an_alternative_view_from_Denmark/links/59198dcdaca2722d7cfe22ea/Security-and-labour-market-flexibility-an-alternative-view-from-Denmark.pdf (дата звернення: 20.09.2020).

9. Engeline Grace van Arkel. A Just Cause for Dismissal in the United States and the Netherlands. URL: https://core.ac.uk/download/pdf/18513911.pdf (дата звернення: 20.09.2020).

10. Protection against unjustified dismissal. International Labour Conference 82nd Session 1995; Report III (Part 4B). URL: https://www.ilo.org/public/libdoc/ilo/ P/09661/09661(1995-82-4B).pdf (дата звернення: 20.09.2020).

11. Краснов Є.В. Проблемні аспекти практики застосуванн п. 5 ч. 1 ст. 41 КЗпП України при розірванні трудового договору. URL: http://dspace.onua.edu.ua/bitstream/handle/11300/5086/Krasnov \% 20\% 20.\% 20V.\% 20Problemn \% 20\% 20aspekti \% 20 praktiki \% 20zastosuvannja \%20p.5\% 20ch.1\%20st.41\%20KZpP\%20Ukra\% 20ni.pdf?sequence=1http:/ / dspace.onua.edu.ua/bitstream/handle/11300/5086/Krasnov\% 20\%20 .\% 20V.\%20Problemn \% 20\% 20aspekti \% 20praktiki \% 20zastosuvannja \% 20p.5\% 20ch.1\% 20 st.41\%20KZpP\%20Ukra\%20ni.pdf?sequence=1(дата звернення: 20.09.2020).

12. Директиви Ради № 2001/23/ СС «Про наближення законодавств держав-членів, що стосується охорони прав працівників у випадку передачі підприємств, бізнесових структур або частин підприємств або бізнесових структур» від 12 березня 2001 p. URL: https://minjust.gov.ua/m/str_45891 (дата звернення: 20.09.2020).

13. Додаток XL до гл. 21 Угоди про асоціацію між Україною та Європейським Союзом, Європейським співтовариствам з атомної енергії від 27 червня 2014 p. URL: https://www.kmu.gov.ua/storage/app/media/ugoda-pro-asociaciyu/40_Annex.pdf (дата звернення: 20.09.2020).

14. Рекомендація МОП № 166 щодо припинення трудових відносин 3 ініціативи роботодавця від 22 червня 1982 p. URL: https://zakon.rada.gov.ua/laws/ show/993_276\#Text (дата звернення: 20.09.2020)

15. Якименко М.М. Право на працю в міжнародних документах та його закріплення в законодавстві України. Право і Безпека. 2006. Т. 5. № 2. С. 125-129.

16. European Committee of Social Rights. Conclusions 2014 - Ukraine - Article 4-4. URL: $\quad$ https://hudoc.esc.coe.int/eng\#\{"fulltext":["Conclusions\%20XIV-2\%20(1998),\%20 Belgium"],"sort":["ESCPublicationDate\%20Descending,ESCDcTypeOrder\%20Ascending,ESCStatePartyOrder\%20Ascending,ESCArticleOrder\%20Ascending"],"ESCDcIdenti- 
fier":["2014/def/UKR/4/4/EN"],"ESCDcType":["FOND","Conclusion","Ob"]\} (дата звернення: 20.09.2020).

17. Artan Çela. Dismissal Procedures in Albania: A Comparative Study. URL: https://pdfs.semanticscholar.org/2967/b876751668ee3ffdcd6f7fc1d9303d47f6a3.pdf?_ga= 2.120176264.1013467532.1601043355-907191736.1586877347 (дата звернення: 20.09.2020)

18. Barlow P., Reeves A., McKee M., Stuckler D. Employment relations and dismissal regulations: Does employment legislation protect the health of workers? URL: https:/ / onlinelibrary.wiley.com/doi/full/10.1111/spol.12487 (дата звернення: 20.09.2020).

19. Золотухіна Л.О. Вихідна допомога: правова природі, проблеми яинного та перспекивного правового регулювання. Науковий вісник Дніпропетровського державного університету внутрішніх справ. 2017. № 1. С. 139-147.

20. Юрик Я.І. Законодавчий захист зайнятості в Україні: оцінювання жорсткості та напрями лібералізації. Економіка та держава. 2016. № 5. С. 49-57. 
УДК 349.2

DOI https:// doi.org/10.32850/LB2414-4207.2020.14.15

\title{
ПРАВОВЕ РЕГУЛЮВАННЯ ТРУДОВИХ ВІДНОСИН ХАРТІЕЮ ОСНОВОПОЛОЖНИХ ПРАВ ЕВРОПЕЙСЬКОГО СОЮЗУ
}

\author{
Рим Олена Михайлівна, \\ кандидат юридичних наук, \\ доцент кафедри соціального права \\ (Львівський національний університет \\ імені Івана Франка, \\ м. Львів, Україна)
}

Стаття присвячена комплексному з'ясуванню правового регулювання трудових відносин Хартією основоположних прав Європейського Союзу (далі - Хартії). Наголошується, що чимало положень Хартії, які закріплюють соціальні та трудові права, зорієнтовані на кількісне та якісне зростання зайнятості населення. Водночас основні трудові та соціальні стандарти все ж опосередковуються економічним і політичним контекстом. Їхній зміст модифікується разом зі зміною економічних і політичних обставин, а розвиток можливий лише у разі політичної зацікавленості у їхньому ефективному застосуванні. Звертається увага на новаторський характер Хартії, адже, попри той факт, що вона заснована на положеннях Свропейської конвенції про захист прав людини та основоположних свобод (далі - Конвенція), практиці Суду Європейського Союзу та Європейського суду з прав людини та інших європейських і міжнародних інструментах, все ж чимало ії положень є прогресивними. Наприклад, Хартія розширила перелік ознак, за якими заборонялася дискримінація. Новими ознаками стали інвалідність, вік і сексуальна орієнтація. Крім цього, структурна побудова Хартії також засвідчує якісно новий підхід до суті та значення основоположних прав. Підкреслюється, що положення Хартії основоположних прав СС визначають основу правового забезпечення трудових прав на рівні Союзу. Щоправда, певна хаотичність і неструктурованість вибору трудових прав, закріплених у Хартії, не дозволяє охарактеризувати цей акт як цілісний комплекс трудових прав. Більше того, відсутність чіткості та певна розмитість вираження окремих основоположних прав зумовлюють зменшення їхньої важливості у сфері найманої праці. Підсумовується, що Хартія основоположних прав Свропейського Союзу є найбільш розробленим і всеосяжним юридично обов' язковим інструментом захисту прав людини в соціальній сфері Свропейського Союзу. Вона набуває дедалі більшого значення і $є$ першим інструментом, який включає як громадянські, так і політичні права, з одного боку, і соціальні права, з іншого. Попри той факт, що чимало основоположних прав були сформульовані Судом СС задовго до ухвалення Хартії, їхнє закріплення у цьому правовому акті лише додало їм значення та цінності.

Ключові слова: трудові права, Свропейський Союз, Хартія основоположних прав Європейського Союзу, право працювати, свобода асоціації. 


\title{
REGULATION OF LABOUR RELATIONS UNDER THE EUROPEAN UNION CHARTER OF FUNDAMENTAL RIGHTS
}

\author{
Rym Olena Mykhaylivna, \\ Candidate of Law Sciences, \\ Associate Professor at the Department of \\ Social Law \\ (Ivan Franko National University of Lviv, \\ Lviv, Ukraine)
}

The article deals with a comprehensive analysis of the legal regulation of labour relations in accordance with the Charter of Fundamental Rights of the European Union. It is emphasized that many of the Charter's provisions, which enshrine social and labour rights, are focused on quantitative and qualitative employment growth. At the same time, basic labour and social standards are still determined by the economic and political context. Their content is modified due to the changing of economic and political circumstances, and development is only possible if there is political interest in their effective implementation. The attention is drawn to the innovative nature of the Charter. Despite the fact that the European Convention for the Protection of the Human Rights and Fundamental Freedoms, the case law of Court of the European Union and the European Court of Human Rights and international instruments are laid down within its basis the Charter's provisions are considered to be progressive. For example, the Charter expanded the list of non-discriminatory grounds. Disability, age and sexual orientation are recognized as new. In addition, the structure of the Charter also establishes a new approach to the substance and value of fundamental rights. It is pointed out that the Charter of Fundamental Rights of the EU defines the basis for the legal protection of labour rights at Union level. However, the certain chaotic nature and unstructured choice of labour rights enshrined in the Charter does not make it possible to characterize this act as a complete set of labour rights. Moreover, the lack of clarity in the formulation of certain fundamental rights makes them less important in the sphere of labour law. It is concluded that the Charter of Fundamental Rights of the European Union is the most developed and comprehensive legally binding instrument for the protection of human rights in the social sphere of the European Union. The Charter's importance is growing up and the Charter is the first instrument which include both civil and political rights on the one hand and social rights on the other. Despite the fact that many fundamental rights were formulated by the EU Court long before the Charter was adopted, their subsequent consolidation in the Charter only added them value and significance.

Key words: labour rights, European Union Charter of Fundamental Rights, right to engage in work, freedom of association.

Постановка проблеми. Потреба узгодженості законодавства та політики Свропейського Союзу з основоположними правами людини вивела на перший план питання запровадження комунітарного механізму контролю їхньої реалізації. 3 цією метою у 1999 р. Свропейська рада ухвалила рішення про розробку проекту Хартії основоположних прав. Основною метою цього процесу було проголошено потребу досягнення послідовності та ясності реалізації прав, встановлених у різний час по-різному в окремих державах-членах СС.

Наступного, 2000 р. текст Хартії був урочисто проголошений Свропейським Парламентом, Радою та Комісією в м. Ніцца. До підписання Лісабонського договору його правовий статус залишався незрозумілим. Лише 1 грудня 2009 р. Хартія набула прямої 
дії й отримала статус обов' язкового джерела первинного права Свропейського Союзу, адже їй було надано однакову з установчими договорами юридичну силу. Відтепер Свропейський Союз, на переконання багатьох учених, отримав своєрідний «Білль про права» $[1$, с. 6; 2, с. 26]. Відтоді Хартія як частина первинного права ЄС вважається одним із центральних джерел, що регулюють трудові права в СС.

Аналіз останніх досліджень і публікацій. Питання правового регулювання трудових відносин у Свропейському Союзі вивчали багато науковців. Різноманітні аспекти трудового права ЄС були предметом дослідження таких учених, як: О. Головко-Гавришева, О. Дарморіс, С. Добрянський, А. Коротаєва, М. Микієвич, В. Муравйов, Н. Мушак, Р. Петров, Г. Чанишева, І. Яцкевич та ін. Проте комплексно закріплення трудових прав Хартією основоположних прав СС науковцями не з'ясовувалося, а тому потребує детального аналізу.

Постановка завдання. Загострення проблем на ринку праці СС та потреба їхнього вирішення зумовили той факт, що чимало положень Хартії, які закріплюють соціальні та трудові права, зорієнтовані на кількісне та якісне зростання зайнятості населення. Негативні наслідки зміни демографічної ситуації, старіння робочої сили та зменшення народжуваності, що супроводжується високим рівнем безробіття, мали би бути мінімізовані завдяки запровадженню положень Хартії щодо рівних можливостей (наприклад, сприяння участі жінок на ринку праці), соціального захисту (подолання соціального відчуження), робочого часу, нетипових форм організації праці, залучення соціальних партнерів та ін. Характеристика й аналіз відповідних положень Хартії, оцінка їхньої значимості у процесі розбудови соціальної складової частини політики Свропейського Союзу - це основні завдання запропонованої статті.

Виклад основного матеріалу дослідження. Хартія основоположних прав СС об'єднує правове забезпечення особистих, громадянських, політичних, економічних і соціальних прав [3]. Важливо пам'ятати, що основні трудові та соціальні стандарти все ж опосередковуються економічним і політичним контекстом. Їхній зміст модифікується разом зі зміною економічних і політичних обставин, а розвиток можливий лише у разі політичної зацікавленості у їхньому ефективному застосуванні.

Попри той факт, що Хартія заснована на положеннях Європейської конвенції про захист прав людини й основоположних свобод [4], практиці Суду Європейського Союзу та Європейського суду з прав людини та інших європейських і міжнародних інструментах, вона вважалася новаторським правовим актом, зокрема розширила перелік ознак, за якими заборонялася дискримінація. Новими ознаками стали інвалідність, вік і сексуальна орієнтація.

Структурна побудова Хартії також демонструє якісно новий підхід до суті та значення основоположних прав. В основі класифікації основоположних прав перебувають цінності, на захист яких вони спрямовані. До таких, зокрема, належать людська гідність, свобода особи, рівність і солідарність. Комплекс основоположних прав поділено на кілька категорій. Серед них особисті права і свободи, політичні права і свободи, економічні, соціальні та культурні права, а також основні обов' язки.

Положення Хартії основоположних прав СС визначають основу правового забезпечення трудових прав на рівні Союзу. Насамперед варто назвати ст. 5, згідно з якою забороняється примусова чи обов' язкова праця. Формулювання відповідної заборони точно відповідає положенню, закріпленому у Європейській конвенції про захист прав людини й основоположних свобод (ст. 4). Таким чином, розуміння «примусової чи обов'язкової» праці за Хартією та Конвенцією мало б бути однаковим, а заразом повинні визнаватися конвенційні положення, що саме не вважати забороненою роботою з примусу. Оскільки відповідні випадки у Хартії не наводяться, то застосування 
ч. 3 ст. 4 Конвенції є релевантним. Зокрема, у ч. 3 ст. 4 Конвенції йдеться про будь-яку роботу, виконання якої зазвичай вимагається під час призначеного тримання за умов позбавлення свободи або під час умовного звільнення; будь-яку службу військового характеру або у разі, коли особа відмовляється від неї з мотивів особистих переконань у країнах, де така відмова визнається, службу, яка вимагається замість обов'язкової військової служби; будь-яку службу, що вимагається у разі надзвичайної ситуації або стихійного лиха, яке загрожує життю чи благополуччю суспільства; будь-яку роботу чи службу, що є частиною звичайних громадянських обов' язків.

Окремих аспектів регулювання відносин найманої праці стосується ст. 8 Хартії, яка закріплює право кожного на захист персональних даних. Розвиток нових технологій посилює стурбованість втручання у приватне життя особи, особливо у трудових відносинах. Тож закономірно, що право на приватність на роботі отримало наднаціональний рівень правового забезпечення.

Право працювати та право провадити професійну діяльність, яку особа вільно обрала чи на яку надала добровільно згоду, були зараховані до фундаментальних прав СС ст. 15 Хартії, яка поширюється як на найманих працівників, так і на самозайняти осіб. Формулювання «право працювати» (the right to engage in work) обране як компромісне серед пропонованих розробниками Хартії понять «свобода працевлаштування» (freedom to enter into work) i «право на працю» (right to work) [5, с. 29].

Відсутність чіткості у визначенні «права працювати» європейські науковці компенсують вузьким і широким трактуванням цього поняття. Зокрема, у вузькому значенні його розуміють як можливості доступу до ринку праці. Широке тлумачення права працювати стосується політичних зобов'язань держав-членів сприяти стабільній зайнятості та залученню до праці. Наприклад, нормативне виключення окремих категорій працівників із ринку праці вважається неприпустимими діями з боку держави-члена. Відповідне трактування також може бути використане для посилення правової основи зобов' язань Свропейського Союзу у сфері зайнятості [5, с. 30].

Право займатися вільно обраною професійною діяльністю, у свою чергу, охоплює працю за наймом і самозайнятість, можливість припинити виконання трудових обов'язків чи узагалі не працювати, гарантії заборони односторонньої зміни трудового договору та попередження зловживань із боку роботодавця, який потребує виконання повторюваної роботи і тому може нечесно намагатися продовжити взаємодію із працівником [5, с. 30].

Крім цього, ст. 15 гарантує кожному громадянину Союзу можливість вільно шукати роботу, працювати, реалізовувати право на заснування та надавати послуги в будьякій державі-члені. Громадяни третіх країн, котрі мають дозвіл працювати на території держав-членів, отримали право на умови праці, еквівалентні тим, що мають громадяни Союзу.

Розділ III Хартії під назвою «Рівність» вказує на те, що просте визнання загального принципу рівності усіх перед законом (ст. 20) є недостатнім для досягнення його мети без додаткового закріплення заборони дискримінації (ст. 21) та гарантування рівності між чоловіками та жінками (ст. 23). Хартія забороняє будь-яку дискримінацію, незалежно від того, чи така є прямою чи прихованою, виражається через дії чи бездіяльність, стосується індивідуально особи чи колективу. Та все ж певні винятки із загальної заборони дискримінації допускаються. Йдеться, зокрема, про законні вимоги щодо професійної кваліфікації, державної безпеки та захисту самого працівника.

У контексті трудового права відповідна заборона охоплює захист працівника як фізичної особи-індивіда і як члена колективу найманих працівників. Закріплення відповідних положень у сфері найманої праці мають важливе значення, адже диферен- 
ціація правового регулювання трудових відносин є нормальним, допустимим і навіть бажаним явищем. Та все ж зловживання різноманіттям правового регулювання може легко призвести до дискримінаційних наслідків.

Про право працівників на захист від необгрунтованого звільнення йдеться у ст. 30 Хартії. Визнання на наднаціональному рівні відповідного права свідчить про те, що чесні умови працевлаштування та зайнятості повинні бути враховані у правовому регулюванні, спрямованому на гарантування гнучкості роботодавців як учасників ринку. Гарантії, передбачені ст. 30, не поширюються на працівників, які поєднують роботу з виконанням сімейних обов' язків, адже захист їхніх прав у разі необгрунтованого звільнення забезпечується спеціальним законодавством СС про недискримінацію та захист сімейного і професійного життя.

Очікувати на захист за ст. 30 Хартії працівники можуть саме у разі необгрунтованого звільнення. Тому роботодавцю недостатньо стверджувати, що національний закон передбачає положення про те, що звільнення може відбуватися, коли наявні справедливі причини, які зумовлюють припинення роботи. Звільнення повинно відповідати не лише матеріальним, але і процедурним нормам щодо припинення трудового договору. Зокрема, йдеться про право працівника бути почутим та індивідуально консультуватися із роботодавцем щодо звільнення, як і право на отримання інформації про причини звільнення та консультації щодо наслідків припинення трудових договорів на колективному рівні як про елементи процедури, дотримання якої $\epsilon$ необхідним для забезпечення належного захисту за ст. 30 Хартії.

Право на захист від необгрунтованого звільнення також передбачає запобіжні заходи 3 метою попередження звільнення та компенсаційні заходи, щоб полегшити працівнику наслідки втрати роботи. Реалізації усіх цих захисних заходів роботодавцем на практиці має на меті забезпечення обгрунтованого звільнення працівника [6, с. 66].

Питанням забезпечення чесних і справедливих умов праці присвячена ст. 31. Відповідно до ії положень кожен працівник має право на здорові, безпечні та гідні умови праці, які, серед іншого, повинні встановлювати максимальну кількість робочих годин, мінімальну норму щоденного та щотижневого відпочинку, а також щорічну оплачувану відпустку. Відповідне формулювання фактично доповнює норму ст. 1 Хартії, за якою людська гідність вважається непорушною, шанується та захищається. Таким чином, гарантуючи чесні та справедливі умови праці, Хартія охоплює усі умови праці, що можуть вплинути на людську гідність.

Окремою статтею Хартії забороняється дитяча праця. Зокрема, положення ст. 32 встановлюють, що мінімальний вік прийняття на роботу не може бути меншим, ніж мінімальний вік закінчення обов'язкової школи без шкоди більш сприятливим правилам щодо молоді та з урахуванням можливих відступів від цього загального правила в обмежених сферах. Молоді, котра була допущена до виконання роботи, повинні гарантуватися умови праці, які відповідають віку працівників. Крім цього, молоді люди, що працюють, повинні бути захищені від економічної експлуатації та будь-якої роботи, яка може зашкодити їхній безпеці, здоров'ю, фізичному, психічному, моральному або соціальному розвиткові або завадити їхній освіті.

Аналізуючи правове регулювання трудових відносин відповідно до положень Хартії, не можна не зазначити, що ст. 29 закріпила право на доступ до служб працевлаштування. Так само, як і ст. 33, котра встановлює, що з метою збалансованого поєднання сімейного та професійного життя кожен має право на захист від звільнення з причин, пов'язаних із вагітністю та пологами, право на оплачувану відпустку у зв'язку з вагітністю та пологами та на відпустку по догляду за дитиною після народження або усиновлення дитини. Доповнює відповідні гарантії ст. 34, норми якої спрямовані на 
соціальне забезпечення у таких випадках, як: вагітність і пологи, хвороба, виробнича травма, перебування на утриманні або старість, втрата роботи.

Крім індивідуальних трудових прав, які охарактеризовано вище, Хартія основоположних прав СС також забезпечує колективні трудові права. До таких належать право на свободу мирних зібрань і свободу об'єднання на всіх рівнях, зокрема у справах політичних, громадських і профспілкових, включаючи право кожного створювати професійні спілки та приєднуватися до них заради захисту своїх інтересів (ст. 12), право працівників на інформацію та консультацію на підприємстві (ст. 27) та право на колективне ведення переговорів і колективні дії (ст. 28).

Щоправда, певна хаотичність і неструктурованість вибору трудових прав, закріплених у Хартії, не дозволяє охарактеризувати цей акт як цілісний комплекс трудових прав. Більше того, відсутність чіткості та певна розмитість вираження окремих основоположних прав зумовлюють зменшення їхньої важливості у сфері найманої праці.

Попри те, що сфера застосування Хартії, з одного боку, потенційно дуже широка, а більшість визнаних нею прав надаються усім людям незалежно від національності та статусу, ст. 51 обмежує ії застосування. Зокрема, положення Хартії адресовано всім установам, органам, службам та агенціям Союзу з належним дотриманням принципу субсидіарності та державам-членам, лише коли вони застосовують законодавство Союзу. Хартія не розширює сферу використання наднаціонального права поза межі повноважень Союзу, рівно ж як і не надає Союзові нових повноважень і не покладає нових завдань, не змінює повноважень і завдань, визначених в установчих договорах.

Хартія застосовується в такому обмеженому контексті з тієї причини, що сам СС фактично не має власного адміністративного апарату, за допомогою якого він міг би застосовувати законодавство Спільноти в державах-членах. Натомість застосування права ЄС здійснюється силами самих держав-членів. Тому Хартія не діє у сферах, у яких держави-члени не делегували Європейському Союзу свої повноваження.

Наведене формулювання окреслює сфери дії Хартії, національного законодавства держав-членів і Свропейської конвенції про захист прав людини й основоположних свобод. У зв'язку з цим потрібно зазначити, що Хартію іноді плутають із Європейською конвенцією про права людини. Хоча їхні положення частково накладаються на регулювання подібних чи однакових правовідносин, ці правові акти діють в окремих правових рамках. Хартія основоположних прав Європейського Союзу була розроблена СС і тлумачиться Судом Свропейського Союзу. Свропейська конвенція про захист прав людини й основоположних свобод ухвалена Радою Свропи та тлумачиться Європейським судом з прав людини. Водночас, як зазначено у ст. 52 Хартії, тією мірою, якою ця Хартія містить права, що відповідають правам, гарантованим у Свропейській конвенції про захист прав людини та основоположних свобод, значення й обсяг цих прав є тими самими, що їх встановлено Конвенцією. Це положення не перешкоджає гарантувати ширший захист трудових прав на рівні СС. Його метою $\epsilon$ забезпечення згуртованості прав людини й основних стандартів захисту прав і свобод (система Конвенції) та захисту основоположних прав (система Союзу), а також запобігання виникненню розбіжностей між правовими стандартами, розробленими Свропейським судом з прав людини та Судом Свропейського Союзу. Водночас з урахуванням поділу джерел права СС на первинні та вторинні для Суду Свропейського Союзу першочергового значення набула саме Хартія СС, а не Конвенція, попри те, що остання визнана СС одним із загальних принципів його правової системи, які (принципи) теж є джерелами права СС [7, с. 10].

Вивчаючи співвідношення Хартії та Конвенції, потрібно сказати, що Хартія розглядається як загальна рамка прав людини на рівні СС, складовим і найважливішим еле- 
ментом якої є Конвенція. Системний зв'язок між цими актами передбачає однакове застосування та розуміння положень, що є спільними для них [8. с. 165].

Висновки. Хартія основоположних прав Європейського Союзу є найбільш розробленим і всеосяжним юридично обов'язковим інструментом захисту прав людини у соціальній сфері Свропейського Союзу [9, с. 1]. Зрештою, вона внесла основні права профспілок, соціальні та трудові стандарти до політичного порядку денного ЄС [10, с. 91]. Таким чином, положення відповідного правового акта набувають дедалі більшого значення іє першим інструментом, який включає як громадянські, так і політичні права, з одного боку, і соціальні права, з іншого. Попри той факт, що чимало основоположних прав були сформульовані Судом СС задовго до ії ухвалення, їхнє наступне закріплення у Хартії лише додало їм вартісного значення та цінності.

Закріплені Хартією основоположні права часто використовуються для тлумачення інших правових актів ЄС. Наприклад, із 2009 р. (часу набрання Хартією обов'язкової сили) кількість справ, що розглядалися Судом Свропейського Союзу та пов'язані із тлумаченням основоположних прав, значно зросла та продовжує зростати. Зокрема, в кожній десятій справі, яка виноситься на розгляд Суду $С С$, Хартія чітко згадується [2, с. 26]. Це, безумовно, свідчить про те, що відповідні положення і надалі будуть скеровувати процес розвитку права $С$.

\section{Список використаних джерел:}

1. Шишкова Н. Хартия основных прав ЕС и вопросы судебной защиты. Адвокат. 2012. № 11. C. 6-8.

2. Lenaerts K. Speech of the President of the Court of Justice of the European Union, opening of the judicial year, 26 January 2018. In Annual report 2018 - European Court of Human Rights. 190 p.

3. Charter of Fundamental Rights of the European Union. OJ C 326, 26.10.2012, p. 391-407 URL: https://eur-lex.europa.eu/legal-content/EN/TXT/?uri=CELEX:12012P/TXT.-.

4. European Convention on Human Rights URL: https://www.echr.coe.int/Documents/Convention_ENG.pdf.

5. Vigneau C. Freedom to choose an occupation and right to engage in work (Article 15) in European labour law and the EU Charter of Fundamental Rights - summary version European Trade Union Institute (ETUI). Brussels, 2002. 104 p.

6. Bruun N. Protection in the event of unjustified dismissal (Article 30) in European labour law and the EU Charter of Fundamental Rights - summary version - European Trade Union Institute (ETUI). Brussels, 2002. 104 p.

7. Добрянський С. Хартія основних прав Свропейського Союзу: здобутки та перспективи. Вісник Львівського університету. Серія : Юридична. 2014. Вип. 59. С. 9-16.

8. Яцкевич I.I. Гарантування права на працю Хартією основних прав Свропейського Союзу. Юридина наука та практика: Виклики сучасних євроінтеграційних процесів (Pravna veda a prax: vyzoy modernych europskych integracnych procesov : Zbornik prispevkov $\mathrm{z}$ medzinarodnej vedeckej konferencie (Paneuropska vysoka skola, Fakulta prava, Bratislava, 27-28 Novembra 2015 r.). Bratislava : Paneuropska vysoka skola, Fakulta prava, 2015. P. 164-166.

9. Dorssemont F., Lörcher K., Clauwaert S., Schmitt M. The Charter of Fundamental Rights of the European Union and the Employment Relation. Hart Publishing (April 4, 2019). $712 \mathrm{p}$.

10. Bercusson B. Conclusions in European labour law and the EU Charter of Fundamental Rights - summary version - European Trade Union Institute (ETUI). Brussels, 2002. 104 p. 
UDC 347.21

DOI https:// doi.org/10.32850/LB2414-4207.2020.14.16

\title{
ANALYSIS PATENT ACTIVITY OF ORGANIZATIONS AND MANUFACTURERS CONCERNING PHARMACEUTICAL PRODUCTS
}

\author{
Rustamli Fidan Ali gizi, \\ PhD Student \\ (Azerbaijan National \\ Academy of Sciences, \\ Baku, Azerbaijan)
}

The aim of the study is to analyze the activity of pharmaceutical organizations and manufacturers taking into account the benefit of patients as well as public health conditions and assess good manufacturing practices for pharmaceutical products.

To summarize, it is noted that since drug development involves many risks, and because every successful drug molecule is the basis of extensive clinical research and development that takes decades, the patent begins well before drug development. Most countries grant 20 years of patent protection for innovative drugs. Much of this time is wasted in the application and approval process, so it is natural for any innovative company to resort to methods that extend the monopolization period, in particular the practice of greening a patent to recover damages. the huge costs they incur on R\&D.

The research methodology is based on logical, pharmaceutical and sociological concepts, qualitative and quantative research methods as well as document screening.

The scientific novelty of the research is the cross-sectional analysis of the activity of pharmaceutical companies, identifying causes and results of "evergreening" problem.

Conclusions. It is emphasized that improving legislation in one country without the application of appropriate measures by countries around the world may seem ineffective and destructive from the point of view of public health and health of a country that has allowed itself to reduce the level of patent protection. Thus, the author has proved that there is a direct relationship between the degree of patent protection in a state and the speed of new drugs entering its market: if strong patent rights accelerate the import of relevant drugs, then weak patent rights impede the import and increase the availability of harmful drugs. It appears that patent gardening contributes to unfair competition and related abuses. It notes that tighter controls on intellectual property around the world could eradicate such practices, widely adopted by innovative companies, in order to create a gateway for generic companies seeking to provide safe and effective medicines to the general public at cost-effective prices.

Key words: patent, medicinal products, dominant position, subsidiary. 


\title{
АНАЛІЗ ПАТЕНТНОЇ ДІЯЛЬНОСТІ ОРГАНІЗАЦІЙ І ВИРОБНИКІВ ЩОДО ФАРМАЦЕВТИЧНОЇ ПРОДУКЦЇ̈
}

\author{
Рустамлі Фідан Алі кизи, \\ докторант \\ (Національна академія \\ наук Азербайджану, \\ м. Баку, Азербайджан)
}

Метою дослідження $є$ аналіз діяльності фармацевтичних організацій і виробників з урахуванням користі для пацієнтів, а також стану здоров'я населення та оцінки належної практики виробництва фармацевтичних продуктів.

Підбиваючи підсумки, відзначається, що, оскільки розробка ліків пов'язана 3 багатьма ризиками й оскільки кожна успішна молекула лікарського засобу $\epsilon$ основою великих клінічних досліджень і розробок, які займають десятиліття, патент починається задовго до розробки лікарського засобу. Більшість країн надають 20 років патентного захисту інноваційних ліків. Білыша частина цього часу витрачається даремно на процес подачі заявки й отримання дозволу на вихід на ринок, тому для будь-якої інноваційної компанії природно вдаватися до методів, що збільшує період монополізації, зокрема до практики екологізації патенту для відшкодування збитків - величезних витрат, які вони несуть під час науково-дослідних і дослідноконструкторських робіт.

Методологія дослідження грунтується на логічних, фармацевтичних і соціологічних концепціях, якісних і кількісних методах дослідження, а також на перевірці документів.

Наукова новизна дослідження - це крос-секційний аналіз діяльності фармацевтичних компаній, виявлення причин і результатів проблеми «вічнозелених».

Висновки. Підкреслюється, що поліпшення законодавства в одній країні без застосування відповідних заходів країнами всього світу може бути неефективним i деструктивним із боку громадського здоров'я та охорони здоров'я країни, яка дозволила собі знизити рівень патентного захисту. Таким чином, автор довів пряму залежність між ступенем патентного захисту в державі й швидкістю виходу нових ліків на його ринок: якщо сильні патентні права прискорюють імпорт відповідних ліків, то слабкі патентні права перешкоджають імпорту й збільшенню доступності шкідливих для здоров'я ліків. Схоже, що патентне садівництво сприяє розвитку недобросовісної конкуренції та пов' язаних із цим зловживань. Відзначається, що жорсткіший контроль над інтелектуальною власністю в усьому світі міг би викоренити таку практику, яка широко застосовується інноваційними компаніями, щоб створити шлюз для компанійвиробників дженериків, які прагнуть надавати безпечні й ефективні ліки широкому загалу за економічно ефективними цінами.

Ключові слова: патент, лікарські засоби, заявка.

Introduction. Patents are the exclusive ownership of the intangible creations of the human mind. They exist only by the laws of sovereign states that can apply if a patent application is filed covering a territory. Patents are granted for any inventions, regardless of whether they are a product or a method, in all fields of technology, provided that they are novel, contain an inventive step and are industrially applicable.

Patents work in different areas. In the electronics industry, patents are often transferred to competitors through fundraising or printing licensing. This sharing is necessary because one product has many patented technologies. However, in the pharmaceutical, chemical, 
and biotech industries, a patent is usually equivalent to a product, and the necessary research protects a large investment in clinical trials. Patent protection for chemical and pharmaceutical products is especially important when compared to other industries because the actual manufacturing process is often easily replicable and can be copied with a fraction of the investment required for research and clinical trials.

The aim of the study is to analyze the activity of pharmaceutical organizations and manufacturers taking into account the benefit of patients as well as public health conditions and assess good manufacturing practices for pharmaceutical products.

The research methodology is based on logical, pharmaceutical and sociological concepts, qualitative and quantative research methods as well as document screening.

The scientific novelty of the research is the cross-sectional analysis of the activity of pharmaceutical companies, identifying causes and results of "evergreening" problem.

Perpetual greening problem of drug patents. A patent is a property right granted by a sovereign state to the inventor of a new, unclaimed and useful invention. Because the invention must be new (the meaning of which was not previously disclosed anywhere in the world), and because it cannot be discovered, it is a person who owns an art, and the transfer of property rights cannot prevent the public from acquiring what exists. The patent owner has the right to exclude the development, use, sale or sale of another invention within 20 years from the filing of another patent application.

A patent is a form of insurance for innovative pharmaceutical companies. It is known that the greatest risk to manufacturers is associated with prescription drugs. Prescription products are classified into therapeutic categories. Although patents formally prohibit competitors from withdrawing analog drugs before the patent expires, patents do not prevent the manufacture and sale of different drugs for the treatment of the same disease in a given therapeutic category. One such category is COX-2 inhibitors, which are commonly used in the treatment of arthritis. There are various types of prescription and over-the-counter drugs available on the market to treat this condition. Non-steroidal anti-inflammatory drugs (NSAIDs), which are subject to COX-2 inhibitors, are used to treat pain and inflammation associated with arthritis. COX-2 inhibitors are relatively recent and have gained paramount importance due to their ability to reduce the side effects of gastric bleeding and ulcers compared to the prescription of more traditional NSAIDs. However, some of the COX-2 drugs cause serious side effects that affect the heart. Also, COX-2 products are significantly more expensive than prescription NSAIDs. The cost comparison factor is also taken into account when prescribing a drug to a patient. Every patent for an innovative drug that expires requires huge investments for both innovator companies and generic firms and consumers.

Innovative companies are seeking to extend the validity of their patents by registering new invention solutions such as treatment methods, mechanism of action, isomeric forms, delivery profiles, dosage regimen and range, combinations, screening methods, biological targets, and application. As the patent life cycle increases, innovative companies maximize revenues from their "evergreen" products, thereby virtually eliminating any early competition.

Greening patent strategies that are commonly used in the pharmaceutical industry include the following.

Redundant expansion and creation of new generation drugs patented as modern drugs (brand migration). The various points (aspects) of innovative drugs include delivery profiles, manufacturing methods, chemical intermediates, formulations, dosage regimen, isomeric forms, mechanism of action and treatment method, etc. Often, innovators use one of these aspects to obtain additional patents shortly before the expiration of the main patent. Therefore, if a branded pharmaceutical company formulates a new molecule to treat a specific disease, 
the company is eligible for patent protection for different aspects of the parent drug, these additional patents covering different aspects of the same drug will add a term to the total duration of the original patent and limit launch of generic. For example, when the Prilosec patent was nearing its end, AstraZeneca, to maintain its monopoly on Prilosec, released Nexium, which was the same drug with minor changes in design and color [4].

Exclusive partnerships with generic market participants before patent expiration, which significantly increases brand value and allows for product royalties in the interim.

This antitrust practice is widely used by innovative companies that are trying to prevent an appropriate generic drug from entering the market. For example, pioneer companies negotiate with generic manufacturers to delay the time to market for specific generics. A prime example is a tamoxifen, marketed by the pharmaceutical company Astra Zeneca under the trade name Novaldex. Astra Zeneca and generic manufacturer Barr have reached an agreement whereby Astra Zeneca has committed a one-time payment of \$ 66.4 million to delay the release of a generic drug for up to 10 years. Apart that, Barr was able to market tamoxifen, created by AstraZeneca under the Barr brand. Another example is the agreement between AstraZeneca and the Indian generics manufacturer Torrent Pharmaceuticals, under which Torrent has committed itself to the production and supply of generics to the emerging markets of AstraZeneca [5]. The opposite variant of anticompetitive agreements is an agreement between manufacturers of generic drugs directly.

The practice of defensive pricing strategies, when innovative companies reduce the price of a product and bring it in line with the prices of other market players for healthy competition.

Following this practice, innovative companies start selling the cheaper version of the brandname drug as soon as the patent expires, thereby lowering the price of generic counterparts, leaving competitors far behind. Thus, as a result, prices for generics may fall by $40 \%$ or more within two years [6].

Subsidiaries are created by relevant innovative companies before competitors emerge. Pharmaceutical giants have recently shown increasing interest in setting up subsidiaries of generic companies and entering into partnerships with major generic manufacturers before competition from generic players increases. Over the past decade, Big Pharma companies have acquired small, one-stop divisions to expand their business model. [5].

\section{US policy}

In 1984, the US passed the Hatch-Waxman Act to find a balance between the interests of generic and innovative drug manufacturers. It was proposed to find this balance using certain provisions, useful both for the manufacturer of generics and for the companiesinnovators. Thus, the said law contains a provision on the remuneration of the generic manufacturer who is the first to challenge the innovator's patent. The first generic applicant, if successful in challenging the patent, receives a 180-day exclusive period, which allows the generic manufacturer to sell its products exclusively. The 180-day exclusive period recognizes the public interest in encouraging generic manufacturers to release generic versions of innovative medicines and to block the unjustified monopolies enjoyed by green patents. Under the Hatch-Waxman Act, a new procedure has been introduced whereby a generic drug manufacturer can file an ANDA (Abbreviated New Drug Application) application with the US Food and Drug Administration (FDA). The fundamental fact behind this scheme is that if an innovative drug is already approved, then it will need to demonstrate identical biological effects to obtain authorization and market launch of its generic version, and not to repeat clinical trials over and over again. To balance the interests of the innovative companies, the law requires a generic applicant to choose one of four certifications about the patent status of a competing generic:

- the point I - the medicine is not patented; 
- point II - the term of the drug patent has expired;

- clause III - the patent expires by the time the generics appear on the market;

- clause IV - the patent will not be infringed or the patent is invalid [8].

\section{EU policy}

There are not many laws in the European Union on the prevention of perpetual greening, but it should be noted that perpetual greening in the European Union is considered an abuse of dominant position and is regulated under Art. 102 Treaty on the Functioning of the European Union (TFEU). Because a patent is an exclusive right granted to the patentee, and the patent owner has the right to use the patent monopoly, the actions of the copyright holder cannot always be considered an abuse of dominant position. Evergreen appears to be forcibly included within the scope of Art. 102, therefore, this article needs a narrow and clear definition to be consistent with the concept of evergreen, since the existing definition is too broad and it seems impossible to use this provision.

\section{India politics}

In India, there is increased lobbying against the inclusion of data exclusivity clauses for the pharmaceutical and agrochemical sectors, as this is believed to be in the interest of the state. Moreover, it is pointed out that the inclusion of such provisions could have a huge impact on the generic pharmaceutical industry and could delay the entry of cheaper drugs into the market. The inclusion of a data exclusivity clause in the Indian intellectual property regime would also entail the concept of patent greening.

Under Indian law, new forms of already known substances are not patented unless proven to increase the known potency of a previously known substance. The purpose of introducing such a limitation was to limit the practice of perpetual gardening. Section 3 (d) limits the patentability of certain newer forms of older substances if they do not meet the requirement for enhanced performance criteria. Thus, the law states that "the discovery of a new form of a known substance that does not lead to an increase in the known effectiveness of this substance, or the discovery of any new property or new use of a known substance, or the use of a known method, cannot be patented, Thus, legislation sets higher patentability standards for new forms of already known substances. Moreover, such a provision has already established itself as an effective provision in the examination of evergreen patents.

Interesting in the context of the greening theme is the decision of the Supreme Court of India to refuse to grant a patent to the Swiss pharmaceutical company Novartis for a new version of the anti-cancer drug Gleevec (active ingredient is imatinib mesylate). According to Novartis, the patented drug is more readily absorbed into the bloodstream than previously patented drugs and, given that it is used to combat leukemia, this is sufficient to provide patent protection. As a result of six years of proceedings, the Court found that, according to patent law, to provide patent protection, a new version of an old drug must demonstrate increased efficiency [1]. Interesting, Moreover, at the time of these decisions, India was the first country in the world to take this step. Today, this practice is becoming widespread: in particular, the Moscow Arbitration Court on January 25, 2019, satisfied the claim of Nativa LLC for the issuance of a compulsory license to use a patent for a drug with INN sunitinib owned by Sugen LLC and Pharmacia \& Upjohn Company. Note that since 1995, more than a hundred attempts have been made to obtain compulsory licenses [3]. About antitrust regulation, the Federal Antimonopoly Service of the Russian Federation takes an active position on the issue of banning greening of patents, introducing bills and draft bylaws for consideration. In developed countries such as the United States, the European Union, and the Russian Federation, patent laws are too lenient to have a positive effect on reducing the number of evergreen patents. India is doing the opposite. As shown in the Novartis case, India has given a clear indication that the government will not risk public health and health 
care in general by allowing perpetual greening of drug patents. The Novartis decision sent a powerful signal to the world and innovative firms that India would only grant an extended market monopoly to pharmaceutical companies if it was demonstrated that a drug was indeed innovative and significantly improved in efficacy. Although the mechanisms are not yet established, and the actions of government agencies are often criticized, on the whole, an approach aimed at eliminating green patents seems to be correct.

Conclusions. It is emphasized that improving legislation in one country without the application of appropriate measures by countries around the world may seem ineffective and destructive from the point of view of public health and health of a country that has allowed itself to reduce the level of patent protection. Thus, the author has proved that there is a direct relationship between the degree of patent protection in a state and the speed of new drugs entering its market: if strong patent rights accelerate the import of relevant drugs, then weak patent rights impede the import and increase the availability of harmful drugs. It appears that patent gardening contributes to unfair competition and related abuses. It notes that tighter controls on intellectual property around the world could eradicate such practices, widely adopted by innovative companies, in order to create a gateway for generic companies seeking to provide safe and effective medicines to the general public at costeffective prices.

\section{References:}

1. Alice de Pastor. Latest news of medicinal products SPCs in Europe, 29th Alice de Pastors' SPC News, October 2016. URL: http://thespcblog.blogspot.com/2012/05/latestnews-on-medicinal-product-spcs.html.

2. Graul A.I., Sorbera L., Pina P., Tell M., Cruces E., Rosa E., Stringer M., Castañer R., Revel L. The year's new drugs \& biologics 2009. Drug News \& Perspectives. 2010. No. 23 P. 1.

3. Graul A.I., Cruces E., Stringer M. The year's new drugs \& biologics 2014. Part I. Drugs of Today. 2015. No. 51 (1). P. 37-87.

4. Katzka C. Interpretation of the term "product" in EU Council Regulations 1768/92 and 1610/96 on Supplementary Protection Certificates. Journal of Intellectual Property Law E Practice. 2008. No. 3 (10). P. 650-59.

5. Kyle M. Economic analysis of supplementary protection Ccertificates in Europe, unpublished mimeo, European Commission. 2017. URL: https://ec.europa.eu/growth/ industry/policy/intellectual-property/patents/supplementary-protection-certificates_en. 
УДК 347.1

DOI https:// doi.org/10.32850/LB2414-4207.2020.14.17

\title{
МАТЕМАТИЧНІ ОЗНАКИ У ФОРМУЛАХ ВИНАХОДУ, ПОВ'ЯЗАНОГО 3 КОМП'ЮТЕРНОЮ ПРОГРАМОЮ
}

\author{
Сидоренко Ольга Володимирівна, \\ кандидат юридичних наук, \\ старший викладач кафедри \\ інформатики та інтелектуальної \\ власності \\ (Національний технічний університет \\ «Харківський політехнічний інститут», \\ м. Харків, Україна)
}

Статтю присвячено аналізу нормативно-правових актів і практики патентних відомств України та інших країн світу, на підставі яких видаються патенти на винаходи, формули яких містять як технічні, так і чисто математичні ознаки (наукові). Глобальний процес інформатизації призвів до збільшення кількості формул винаходів (корисних моделей), де математичні вирази використовуються для відображення (вираження) не тільки предметних, фізичних ознак реального об'єкта, але і суто математичних. Така тенденція веде до зміни парадигми класичного патентного права і заслуговує критичного розгляду. Цим і зумовлена актуальність теми та необхідність уточнення визначення поняття «винахід» і викладення його таким чином (з урахуванням використання комп'ютерної програми у винаході): «Винахід, пов'язаний із комп'ютерною програмою» - технічне рішення, яке відповідає умовам надання правової охорони (не суперечить публічному порядку, принципам гуманності та моралі) та критеріям патентоздатності (є новим, має винахідницький рівень, є промислово придатним), результат втілення якого в об'єкти обчислювальної техніки (пристрій, спосіб) має технічний характер». Остання, «четверта» умова патентоздатності призначена для винаходу, а «третя» - для корисної моделі. Дефініція «винахід, пов'язаний із комп' ютерною програмою», повною мірою охоплює зв' язок між «логіко-математичними ознаками», що характеризують процес (спосіб), і «технічними ознаками», які відображатимуть сам об'єкт винаходу (пристрій). Питання використання математичних виразів у формулі винаходу розглядалося багатьма авторами, такими як Т.М. Арешев, В.А. Афанасьєв, С.А. Горчинський, В.I. Жуков, В.І. Забежинський, Е.П. Поліщук, B.В. Мокришев, І.І. Кічкіне, Б.К. Кретов, Е.П. Скорняков, Н.П. Шепелєв. Актуальність теми також зумовлюється відсутністю комплексного підходу у науці цивільного права до патентно-правової охорони прав, пов' язаних із комп'ютерною програмою, в абсолютних правовідносинах.

Ключові слова: комп'ютерна програма, винахід, формула винаходу, математичний вираз, патентне відомство, винахід, пов' язаний із комп'ютерною програмою. 


\title{
MATHEMATICAL SIGNS IN THE FORMULAS OF THE INVENTION RELATED TO A COMPUTER PROGRAM
}

\author{
Sydorenko Olha Volodymyrivna, \\ PhD in Law, \\ Senior Lecturer at the Department of \\ the Computer Science and Intellectual \\ Property \\ (National Technical University \\ "Kharkiv Polytechnic Institute", \\ Kharkiv, Ukraine)
}

The article is devoted to the analysis of normative legal acts and practice of patent offices both in Ukraine and other countries of the world. On the basis of which patents for inventions are issued and the formulas of which contain both technical and purely mathematical features (scientific). The global process of informatization has led to an increase in the number of claims (utility models), where mathematical expressions are used to reflect (express) not only the substantive, physical features of a real object, but also purely mathematical. This trend leads to a paradigm shift in classical patent law and deserves critical consideration. This is due to the relevance of the topic and the need to clarify the definition of "invention" and state it as follows (taking into account the use of a computer program in the invention): "Invention related to a computer program" - a technical solution that meets: conditions of legal protection (does not contradict public order, principles of humanity and morality) and criteria of patentability (is new, has an inventive step, is industrially applicable), the result of which, in the objects of computer technology (device, method), has a technical nature. The last "fourth" condition of patentability is intended for the invention, and the "third" condition - for the utility model. This definition of "invention related to a computer program" fully covers the relationship between "logical and mathematical features" that characterize the process (method) and "technical features" that reflect the object of the invention (device). The question of the use of mathematical expressions in the claims was considered by many authors in various aspects: T.M. Areshev, V.A. Afanasyev, S.A. Gorchinsky, V.I. Zhukov, V.I.Zabezhinsky, E.P.Polishchuk, V.V.Mokrishev, I.I.Kichkine, B.K.Kretov, E.P.Skornyakov, N.P. Shepelev. The relevance of the topic is also due to the lack of a comprehensive approach in the science of civil law to the patent protection of rights related to the computer program, in absolute legal relations.

Key words: computer program, inventions, claim, mathematical expressionsб patent office, invention related to a computer program.

В Україні багато років спостерігається ситуація, коли винахідники (поряд із правильно оформленими заявками на винахід) подають у ДП «Український інститут інтелектуальної власності» (далі - патентне відомство) заявки й отримують патенти, які лише за формою представлені у вигляді суто технічного рішення (в рамках класичної парадигми патентного права). Аналіз патентів, виданих саме за такими заявками, свідчить, що патентна формула винаходу містить як технічні, так і математичні ознаки (наукові).

Це, наприклад, патент України на корисну модель «Спосіб прогнозування прогресування гіпертонічної хвороби, асоційованої з абдомінальним ожирінням, за допомогою математичного моделювання» (№ 98000 від 10 квітня 2015 р.) [1]. Суть винаходу полягає в тому, що «для індивідуальної кількісної оцінки тяжкості перебігу гіпертонічної хвороби, асоційованої з абдомінальним ожирінням, розраховують в автома- 
тичному режимі в Exele прогностичний індекс (П Ігх) за допомогою створеної математичної моделі за формулою:

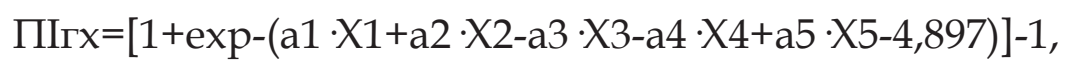

де: ПІгх - прогностичний індекс; (x1-x5) - можливі значення предикторів у конкретного хворого, a1 (0,014), a2 (11,895), a3 (3,976), a4 35 (6,054), a5 (0,058) - значення коефіцієнтів значимості».

Або патент на корисну модель «Спосіб створення комп'ютерних файлів з дизайн-макетами рекламної продукції» (№ 41380 від 25 травня 2009 р., бюл. № 10) [2]. Суть його полягає у збільшенні товщини набризкування бетонного покриття, яке визначають за формулою:

$$
\mathrm{H}=\mathrm{A}_{\text {маш }} \cdot \mathrm{t}_{\text {роб }} \cdot \mathrm{K}_{\text {утр }} \cdot \mathrm{K}_{\text {кер }} \cdot \mathrm{K}_{\text {пор }} / \mathrm{S}_{\text {еіф }}
$$

Ще у квітні 2013 р. компанія Microsoft «опублікувала інформацію, яка дозволить познайомитися з базоюданих, що містить 40785 подібнихпатентів», наприклад, «Оптимізація програмного забезпечення транзакційних операцій з пам'яттю» (Optimization of software transactional memory operations) патент № AU2006200047B2 [3].

В Австралії - «Ліцензування використання програмного забезпечення на певному процесорі» (Licensing the use of software on a particular CPU) патент CN1739107B [4]. Суть полягає в ліцензуванні «програмного забезпечення для використання на певному обчислювальному пристрої, такому як ігрова консоль або мультимедійна консоль».

Підставою для видачі таких патентів слугує як чинне законодавство країн світу, так і практика патентних відомств.

В Україні законодавцем 22 травня 2003 р. був виключений із Закону України «Про охорону прав на винаходи і корисні моделі» (далі - Закон України) [5] такий об'єкт технології, як «комп'ютерна програма» (ч. 3 ст. 6 «Умови надання правової охорони»), і наведено вичерпний перелік об'єктів технології, на які «не поширюється» правова охорона цього Закону.

Виключена також зі ст. 1 Закону України і класична для патентного права родова ознака винаходу - «технічне рішення». Раніше, ще в попередній редакції ст. 1 Закону України (від 1 червня 2000 р.) було замінено визначення «винахід - технологічне (технічне) вирішення, що відповідає умовам патентоздатності (новизні, винахідницькому рівню і промисловій придатності)» на таке: «результат інтелектуальної діяльності людини в будь-якій сфері технології. У цьому вже тоді проявилася послідовна тенденція у відмові від терміна «техніка».

Крім того, між основними положеннями чинного Закону України за умовами надання правової охорони об'єктів винаходу (корисної моделі), зокрема продукту (пристрою); процесу (способу) як «результату інтелектуальної діяльності людини в будь-якій сфері технології», та положеннями чинного підзаконного акта - Правил складання та подання заявки на винахід і заявки на корисну модель (далі - Правила-1) [6], є суттєві суперечності.

Правила-1, на відміну від чинного Закону України, справедливо визнають об'єктами винаходу (корисної моделі) «результат інтелектуальної діяльності людини в будь-якій сфері технології», котрий має ознаки «технічного завдання», «вирішення якої спрямовано на технічний результат, якого можна досягти при здійсненні винаходу (корисної моделі) »(п. 6.6.1, 6.6.2, 6.6.3 Правил-1).

На особливу увагу заслуговує п. 10.2.3 Правил-1 «Особливості викладу опису винаходу», котрий говорить: «Якщо пристрій містить елемент, охарактеризований на функціональному рівні, і форма його реалізації передбачає використання багато- 
функціонального засобу, що програмується (настроюється), то наводять відомості, які підтверджують можливість здійснення таким засобом конкретної, призначеної йому у складі цього пристрою функції. Якщо крім таких відомостей наводять алгоритм, наприклад, обчислювальний, то його переважно подають у вигляді блок-схеми або, якщо це можливо, у вигляді відповідного математичного виразу».

Аналіз свідчить, що в п. 6.6.2 Правил-1, які визначають суть винаходу (корисної моделі), введено дві ознаки (обидві суттєві), а саме:

1) «технічна задача» - ця ознака відсутня у ст. 1 Закону України (в редакції від 15 грудня 1993 р.);

2) ознака «технічний результат» теж відсутня у ст. 7 цього Закону України (в редакції від 15 грудня 1993 р.) («Умови патентоздатності винаходу, корисної моделі») поряд із відомими ознаками (класичними: новизною, винахідницьким рівнем, промисловою придатністю).

Аналіз другої редакції легального визначення винаходу, сформульованого законодавцем у ст. 1 «Визначення» Закону України (в редакції від 01 червня 2000 р.): «винахід - технологічне (технічне) вирішення, що відповідає умовам патентоздатності (новизні, винахідницькому рівню і промисловій придатності)», свідчить про інше. По-перше, можна вважати, що видова ознака «технічна задача» (із Правил-1) логічно випливає з родової ознаки «технологічне (технічне) вирішення» (із Закону України), оскільки є відповідне посилання законодавця на те, що мається на увазі не будь-яке технологічне вирішення, а саме технічне. Але ознака «технічний результат» (із Правил-1) у ст. 7 Закону України (у редакції як від 01 червня 2000 р., так і від № 816-IX від 21 липня 2020 р.) («Умови патентоздатності винаходу, корисної моделі») відсутня поряд із відомими (класичними: новизною, винахідницьким рівнем, промисловою придатністю).

Остання редакція легального визначення поняття винаходу в Україні, яке діє сьогодні, сформульована у ст. 1 «Визначення термінів» Закону України (в редакції від 22 травня 2003 р. та № 816-IX від 21 липня 2020 р.), відрізняється від першої редакції 15 грудня 1993 р. лише тим, що у словосполученні «в будь-якій галузі технології» слово «галузь» замінено на слово «сфера».

Зміни в нормативно-правових актах України проведено з метою узгодження патентного законодавства України зі ст. 27 Угоди ТРІПС «Патентовані об'єкти» (15 квітня 1994 р.), згідно з якою патенти видаються на «будь-які винаходи», незалежно від того, $\epsilon$ вони продуктом чи способом у усіх сферах техніки* (технології**), мають новизну, мають винахідницький рівень і є промислово придатними; та ст. 52 СПК «Патентоздатність» (05 жовтня 1973 р. правка до ст. 52 була внесена актом перегляду ЄПК від 29 листопада 2000 р. (2001)) згідно з якою європейські патенти видаються в усіх сферах техніки (технології*), які $є$ новими, промислово придатними та мають винахідницький рівень».

Виникає запитання: наскільки аналізований п. 6.6.2 Правил-1, який містить терміни (ознаки) «технічна задача» та «технічний результат», логічно випливають зі ст. 27 Угоди ТРІПС [7] і ст. 52 СПК [8]?

Спочатку слід звернути увагу на переклад із тексту оригіналу Угоди ТРІПС та ЄПК українською, російською мовами на слова «у всіх сферах техніки» або «у всіх сфеpax технологіï? У різних виданнях ми зустрічаємо різні переклади. Так, у виданні російською в ч. 1 ст. 27 Угоди ТРІПС «Патентовані об'єкти» читаємо: «во всех областях техники». Та сама ч. 1 ст. 27 Угоди ТРІПС «Патентоздатність об'єктів» у перекладі українською має іншій зміст, а саме: «у всіх сферах технології». Між тим, англійські слова technique (техніка) та technology (технологія) не є синонімами. Припустимо, що 
правильним перекладом є слово «техніка», а не «технологія». Тоді редакція ст. 1 чинного Закону України - легальне визначення поняття винахід - буде такою: «винахід (корисна модель) - результат інтелектуальної діяльності людини в будь-якій сфері техніки». Одним словом, залишається відкритим питання щодо відповідності п. 6.6.2 Правил-1 ч. 1 ст. 27 Угоди ТРІПС; ч. 1 ст. 52 СПК; ст. 1 та 7 Закону України.

На жаль, такому явищу з боку наукової спільноти цивілістів, зокрема тих, хто займається патентним правом, не було приділено достатньої уваги, і з'явилася прогалина. Необхідно заповнити іiі, оскільки без чіткого уявлення про легальне визначення поняття «винахід» неможливо вирішувати проблему ні щодо класичних об'єктів патентного права (продукту, процесу або устрою, способу, речовини), ні, тим більше, щодо винаходу (устрою, способу, об'єктів обчислювальної техніки), пов' язаного з комп'ютерною програмою. Такого висновку дійдемо, якщо будемо використовувати і термінологію Європейського патентного відомства (далі - ЄПВ) (СС), а саме: стосовно винаходу, пов' язаного з комп'ютером.

Проаналізувавши законодавчо закріплене визначення поняття «винахід», пропонуємо його авторське визначення відповідно до чинного сьогодні законодавства України (патентного). Термін «патентне законодавство» вживаємо умовно, оскільки офіційно чинне законодавство України його не використовує. Так само, як і не використовується термін «промислова власність», за окремими винятками.

Отже, керуючись ст. 1, 6, 7 Закону України, можна дати таке визначення поняттю «винахід». Винаходом визнається результат інтелектуальної діяльності людини в будь-якій сфері технології (ст. 1), який відповідає: 1) умовам надання правової охорони (не суперечить публічному порядку, принципам гуманності та моралі) (ст. 6); 2) умовам патентоздатності винаходу (є новим, має винахідницький рівень, є промислово придатним) (ст. 7).

У більш стислій формі визначення поняття «винахід» може бути таким: «Винаходом визнається результат інтелектуальної діяльності людини в будь-якій сорері технологї, який не суперечить публічному порядку та є промислово придатним, новим і має винахідницьький рівенъ».

Корисна модель - результат інтелектуальної діяльності ююдини у сорері технологіі (ст. 1), що відповідає: 1) умовам надання правової охорони (не суперечить публічному порядку, принципам гуманності та моралі) (ст. 6) та 2) умовам патентоздатності винаходу (є новим, і промислово придатним) (ст. 7).

Щодо «винаходу, пов'язаного з комп'ютерною програмою», то слід більш детально досліджувати як результати інтелектуальної діяльності людини в будь-якій сфері технології, так і в IT-технологіiі, які відповідають 1) умовам надання правової охорони (ст. 6); 2) умовам патентоздатності винаходу (ст. 7). Досліджуються не усі критерії патентоздатності винаходу, а лише ті, які є білыш суперечливими серед учених і практиків щодо необхідності введення додаткового критерію («четвертого») до трьох відомих (новизни, винахідницького рівня, промислової придатності). Йдеться про так звану «принципову патентоздатність» (цей термін використовував ще К.К. Яічков). Висловлюючись сучасною мовою, йдеться про наявність / відсутність у результаті інтелектуальної діяльності людини ознак «технічного характеру», або «технічного результату».

Тому наступне визначення поняття, яке пропонується: «винахід, пов'язаний iз комп'ютерною програмою», або ж його синонімом є «Винахід (корисна модель), що характеризується програмним (тобто математичним) забезпеченням ЕОМ», з урахуванням ознак, запозичених як із чинного Закону України, так і з пропозицій фахівців у галузі патентного права закордоном (зокрема ФРН) щодо так званого «четвертого» критерію патентоздатності винаходів поряд із трьома відомими: 
«Винахід, пов'язаний із комп'ютерною програмою» - технічне рішення, яке відповідає: умовам надання правової охорони (не суперечить публічному порядку, принципам гуманності та моралі) та критеріям патентоздатності (є новим, має винахідницький рівень, є промислово придатним), результат втілення якого в об'єкти обчислювальної техніки (пристрій, спосіб) має технічний характер». Остання «четверта» умова патентоздатності призначена для винаходу, а «третя»для корисної моделі.

\section{Список використаних джерел:}

1. Корисна модель № 98000 від 10 квітня 2015 р. «Спосіб прогнозування прогресування гіпертонічної хвороби, асоційованої з абдомінальним ожирінням, за допомогою математичного моделювання». Український інститут промислової власності (Укрпатент). URL: https://base.uipv.org/searchINV/search.php?action=viewdetails\&Id Claim $=211195 \&$ chapter $=$ biblio.

2. Корисна модель № 41380 від 25 травня 2009, бюл. № 10 «Спосіб створення комп'ютерних файлів з дизайн-макетами рекламної продукції». Український інститут промислової власності (Укрпатент). URL: https:/ / base.uipv.org/searchINV/search. php?action $=$ viewdetails\&IdClaim $=102771 \&$ chapter $=$ biblio.

3. Патент № AU2006200047B2 від 28 листопада 2012 р. («Оптимізація програмного забезпечення транзакційних операцій 3 пам'яттю» («Optimization of software transactional memory operations»). URL: https://patents.google.com/patent/ CN101542437A/en.

4. Патент № CN1739107В від 09 грудня 2014 р. «Ліцензування використання програмного забезпечення на певному процесорі» («Licensing the use of software on a particular CPU»). URL: https:/ / patents.google.com/patent/US7552341.

5. Про охорону прав на винаходи і корисні моделі : Закон України від 15 грудня 1993 р. № 3687-XII : із змінами і доповненнями, внесеними Законами України від 1 червня 2000 р. № 1771-III (Законом України від 01 червня 2000 р. № 1771-III цей Закон викладено в новій редакції: від 21 грудня 2000 р. № 2188-III, від 10 січня 2002 р. № 2921-III, від 4 липня 2002 р. № 34-IV, від 15 травня 2003 р. № 762-IV, від 22 травня 2003 р. № 850-IV, в редакції № 816-IX від 21 липня 2020 р.). Відомості Верховної Ради Украйни. 1994. № 7. С. 32.

6. Правила складання і подання заявки на винахід та заявки на корисну модель № 22 від 22 січня 2001 р. : із змінами, внесеними згідно з Наказами Міністерства освіти і науки № 154 (z0332-04) від 26 лютого 2004 р. № 223 (z0460-05) від 14 квітня 2005). Офіизіӥний вісник України. 2001. № 9. С. 382-386.

7. Про торговельні аспекти прав інтелектуальної власності : Угода TRIPS - Угода Світової організації торгівлі про торговельні аспекти прав інтелектуальної власності від 15 квітня 1994 р. Офіиійний вісник України. 2010 р. № 84. С. 503. Ст. 2989.

8. Конвенция о выдаче европейских патентов (Европейская патентная конвенция) от 5 октября 1973 г. : пересмотренная 17 декабря 1991 г. актом пересмотра ст. 63 ЕПК и актом пересмотра от 29 ноября 2001 г. URL: http://www.pseudology.org/Licenziya/ Inter_EuroPatent.htm. 


\title{
АДМІНІСТРАТИВНЕ ПРАВО ТА АДМІНІСТРАТИВНА ДІЯЛЬНІСТЬ
}

УДК $342.98+34.038 .2$

DOI https://doi.org/10.32850/LB2414-4207.2020.14.18

\section{АДМІНІСТРАТИВНО-ПРАВОВІ ЗАСАДИ РЕАЛІЗАЦІЇ СУБ'СКТИВНИХ ПУБЛІЧНИХ ЕКОЛОГІЧНИХ ПРАВ}

\author{
Барліт Антон Юрійович, \\ аспірант кафедри адміністративного \\ та господарського права \\ (Запорізький національний \\ університет, \\ м. Запоріжжя, Україна)
}

У статті визначено адміністративно-правові засади реалізації суб'єктивних публічних екологічних прав приватної особи. Метою дослідження є визначення адміністративно-правових засад реалізації суб'єктивних публічних екологічних прав. Підкреслено, що реалізація суб'єктивного публічного права є неможливою без вчинення суб'єктом владних повноважень певних дій, певного обов'язку, реалізація якого має відбуватися в межах управлінської діяльності в активній формі. До системи суб'єктивних публічних прав віднесено: право особи на власні дії; право особи вимагати від суб'єкта владних повноважень вчинення певних дій; право приватної особи вимагати надання публічних (в тому числі адміністративних) послуг; право на оскарження дій, бездіяльності та іï результатів органів публічної адміністрації. Аргументовано, що об'єктивізація публічного екологічного інтересу пов' язується із його виникненням до моменту набуття повної правосуб'єктності учасником правовідносин та усвідомленням ним соціальної значущості ефективності його реалізації. Обгрунтовано доцільність розуміння під суб'єктивним публічним екологічним правом приватної особи визначеної чинним законодавством можливості участі приватної особи у реалізації природоохоронної (екологічної) функції держави. Визначено, що змістом суб'єктивного публічного екологічного права є задоволення соціального інтересу у запобіганні виникнення надзвичайних екологічних ситуацій, забезпечення раціонального використання природних ресурсів загальнодержавного та місцевого значення, що своїм результатом має зростання рівня якості життя та здоров'я людини. Встановлено, що видами суб'єктивних публічних екологічних прав $є$ і право на вільний доступ до інформації про стан довкілля, і право об'єднуватись у громадські природоохоронні формування, й право на одержання екологічної освіти тощо.

Ключові слова: громадянин, людина, механізм, обов' язки, правовий статус, суб'єктивне публічне право, суб'єктивне публічне екологічне право. 


\title{
THE CONCEPT AND CONTENT OF SUBJECTIVE PUBLIC ENVIRONMENTAL RIGHTS
}

\author{
Barlit Anton Yuriiovych, \\ Graduate Student at the Department of \\ Administrative and Commercial Law \\ (Zaporizhzhia National University, \\ Zaporizhzhia, Ukraine)
}

The scientific article defines the administrative and legal basis for the implementation of subjective public environmental rights of an individual. The purpose of the study is to determine the administrative and legal basis for the implementation of subjective public environmental rights. It is emphasized that the implementation of subjective public law is impossible without the subject of authority to perform certain actions, a certain duty, the implementation of which must take place within the management activities in an active form. The system of subjective public rights includes: the right of a person to his own actions; the right of a person to demand from the subject of power to perform certain actions; the right of an individual to demand the provision of public (including administrative) services; the right to appeal against actions, inaction and its results of public administration bodies. It is argued that the objectification of the public environmental interest is associated with its emergence until the acquisition of full legal personality by the party to the legal relationship, and his awareness of the social significance of the effectiveness of its implementation. The expediency of understanding the subjective public environmental law of an individual is substantiated. It is determined that the content of subjective public environmental law is to satisfy the social interest in preventing environmental emergencies, ensuring the rational use of natural resources of national and local importance, which results in an increase in quality of life and human health. It is established that the types of subjective public environmental rights are the right to free access to information about the state of the environment, and the right to unite in public environmental groups, and receive environmental education, and others.

Key words: citizen, person, mechanism, responsibilities, legal status, subjective public law, subjective public environmental law.

Постановка проблеми. Встановлення змісту та механізмів реалізації прав і свобод особи є пріоритетним завданням сучасної юридичної науки. В цьому аспекті необхідно підкреслити, що визначення сутності системи прав особи, здійснення ії класифікації, вироблення механізмів іï реалізації завжди залишається актуальним питанням наукових та науково-практичних досліджень представників не лише юридичної науки, а й етики, соціології, філософії тощо. Встановлення сутності прав і свобод людини у механізмі держави є предметом досліджень не лише правничої науки, але і досліджень, що проводяться в межах таких галузевих наук, як філософія, етика, соціологія, політологія.

Визначення сутності суб'єктивних публічних прав є неможливим без характеристики та врахування результатів наукових розробок таких вчених, як П.М. Рабінович, А.М. Колодій, О.Ф. Фрицький, В.А. Січевлюк І.О. Ієрусалімова, О.В. Петришин та інших представників науки загальної теорії держава та права, а також науки конституційного права. Окремі аспекти реалізації та захисту суб'єктивних публічних прав вирішувались у межах галузевих досліджень, здійснених, зокрема, такими вченими, як О.В. Негодченко, Т.О. Мацелик, В.К. Колпаков, Т.О. Коломоєць, Ю.О. Легеза, 
О.Ю. Синявська та інші. Однак комплексного дослідження суб'єктивних публічних екологічних прав, визначення їх місця у системі прав людини досі не було здійснено.

Метою дослідження є визначення адміністративно-правових засад реалізації суб'єктивних публічних екологічних прав.

Виклад основного матеріалу. Дослідження категорії суб'єктивних публічних прав спрямовано на встановлення їх сутності не лише як права на власні дії чи права вимагати від інших учасників певних дій, а і як права особи користуватися певними матеріальними та нематеріальними благами 3 метою задоволення певного публічного (соціального) інтересу чи потреби. При цьому під категорією публічного (соціального) інтересу Т.О. Мацелик розуміє забезпечення потреби у здійсненні участі у прийнятті управлінських рішень, реалізації права на участь у політичному житті країни, потреби у доступі до суспільних цінностей і благ, в тому числі до природних ресурсів та природних об'єктів загальнодержавного значення [1, с. 69-70]. Поглиблюючи авторське дослідження категорії «суб'єктивні публічні права», Т.О. Мацелик визначає, що в основу розуміння іiї сутності має бути покладено розуміння іï як визначеної чинним законодавством України можливості приватної особи вимагати від суб'єкта владних повноважень (від органів публічної адміністрації, інших підприємств, установ, організацій незалежно від форм власності, які виконують публічні функції) створення умов для реалізації певної правомочності [1, с. 69-70].

До системи ознак, що характеризують суб'єктивні публічні права, В.А. Федосенко відносить: їх взаємозв'язок із статусом особи, що характеризує ії публічно-правовий статус (зокрема, таким може бути статус державного службовця, судді тощо); спрямованість на задоволення публічного інтересу [2, с. 17]. Як особливу характеристику суб' єктивних публічних прав М.М. Коркунов виділяє підставу та процедуру їх набуття [3, с. 179]. Певною мірою співвідноситься такий підхід із висловленою О.Ю. Синявською концепцією розуміння суб'єктивних публічних прав, що передбачає віднесення їх до структури адміністративно-правового статусу приватної особи [4, с. 53]. M.I. Матузов, проводячи кореляційні зв'язки між суб'єктивними приватними та публічними правами, наголошує, що реалізація перших сприяє задоволенню особистого інтересу, тоді як останні сприяють задоволенню «соціоцентричного» інтересу [5, с. 92].

Таким чином, реалізація суб'єктивного публічного права $є$ неможливою без вчинення суб' єктом владних повноважень певних дій, певного обов' язку, реалізація якого має відбуватися в межах управлінської діяльності в активній формі.

Такий підхід до розуміння категорії «суб'єктивного публічного права» вимагає створення спеціальної системи його захисту, що відповідно до чинного законодавства України реалізується в межах функціонування системи адміністративних судів зокрема. Згідно із статтею 2 Кодексу адміністративного судочинства України завданням функціонування адміністративної юстиції має бути «справедливе, неупереджене та своєчасне вирішення судом спорів у сфері публічно-правових відносин 3 метою ефективного захисту прав, свобод та інтересів фізичних осіб, прав та інтересів юридичних осіб від порушень з боку суб'єктів владних повноважень».

Для розуміння сутності суб' єктивних публічних прав варто здійснити їх класифікацію. За ознакою публічності О. Заверюха виділяє такі групи суб'єктивних публічних прав, як право особи впливати на управлінські процеси, право брати участь у державній і суспільно-політичній діяльності, право користуватися визначеними чинним законодавством правами та свободами, право оскарження управлінських дій та їх результатів, в тому числі і їх відсутність [6, с. 50]. Т.О. Мацелик суб'єктивні публічні права класифікує на право участі в організації та спрямуванні діяльності держави; право на позитивні послуги з боку держави; право на юридичний захист з боку держави у судовому порядку [1, с. 580]. 
З урахуванням зазначеного в межах нашого дослідження під суб'єктивним публічним правом розуміється визначена чинним законодавством можливість приватної особи брати участь у здійсненні управлінської діяльності, спрямованої на задоволення публічного (загальносоціального) інтересу, реалізація якого пов'язується із створенням спеціальної системи правового захисту загалом і системи судового оскарження дій, рішень та результатів діяльності суб'єктів владних повноважень зокрема.

До системи суб' єктивних публічних прав належать: по-перше, право особи на власні діï; по-друге, право особи вимагати від суб'єкта владних повноважень вчинення певних дій; по-третє, право приватної особи вимагати надання публічних (в тому числі адміністративних) послуг; по-четверте, право на оскарження дій, бездіяльності та ії результатів органів публічної адміністрації.

Отже, необхідно підкреслити, що формування концепції суб'єктивних публічних прав розуміється крізь призму розуміння такої категорії, як «публічний інтерес». При цьому власне активізація досліджень із нормативного закріплення категорії «публічний інтерес» визначається як складник права людини на безпечне довкілля, що вже у 60-х роках минулого століття набуло особливо важливого значення у зарубіжних країнах. Зокрема, у Сполучених Штатах Америки нормативне розуміння поняття «публічного інтересу» пов' язано передусім із судовим захистом екологічних інтересів і цінностей [7, с. 198]. Така нормативна тенденція до закріплення публічного екологічного інтересу як складника системи прав і свобод людини та громадянина підтримана у теорії та практиці країн Європи. Зокрема, відповідно до загального адміністративного права здійснюються спроби інституціоналізувати категорію публічного інтересу [7, с. 198]. Відповідно до постулатів загального адміністративного права Федеративної Республіки Німеччини публічний інтерес розглядається скоріше як природний інтерес особистості, що отримав «вірне трактування» й відповідне закріплення в нормативно-правових документах [8, с. 100].

Такий підхід до розуміння теорії інтересу в загальному адміністративному праві Федеративної Республіки Німеччини тісно співвідноситься із конструкцією суб'єктивного публічного права. В межах загального адміністративного права Федеративної Республіки Німеччини суб'єктивне публічне право розуміється як створення механізму дотримання прав, свобод та законних інтересів приватних осіб, набутті ними статусу повноцінних та рівноправних учасників адміністративних правовідносин, отримуючи внаслідок цього можливість за власною ініціативою вступати у відносини із представниками публічної влади та вимагати від них відповідної поведінки [9, с. 234]. Саме реалізуючи суб'єктивне публічне право, приватні особи стають активними учасниками адміністративно-правових та адміністративно-процесуальних суспільних відносин, самостійним щодо органів публічної влади. Суб'єктивне публічне право виявляється у тому, що правова норма водночас спрямована на досягнення публічного інтересу і інтересу окремого індивіда. У результаті законодавством встановлюється відповідальність адміністрації стосовно громадянина, а тому гарантується можливість захисту інтересів [8, с. 100].

P.С. Мельник та В.М. Бевзенко, аналізуючи сутність та особливості публічного та приватного інтересу, зазначають, що публічним $є$ «інтерес, який має будь-яка особа на безумовній основі»; це своєрідна «квінтесенція інтересів членів суспільства, поєднання інтересів, важливих для кожного» [9, с. 244] (громадська та екологічна безпека, якість життя, доступність соціальних благ тощо).

Таким чином, суб'єктивні публічні права реалізуються в певних сферах суспільних відносин реалізації зовнішньої та внутрішньої державної політики загалом і в сфері забезпечення вимог національної безпеки зокрема. Відповідно до нормативно- 
правових положень Закону України «Про національну безпеку України» встановлено, що державна політика у сферах національної безпеки і оборони спрямовується на забезпечення воєнної, зовнішньополітичної, державної, економічної, інформаційної, екологічної безпеки, кібербезпеки України тощо, а загрози національній безпеці України та відповідні пріоритети державної політики у сферах національної безпеки і оборони визначаються у Стратегії національної безпеки України, Стратегії воєнної безпеки України, Стратегії кібербезпеки України, інших документах з питань національної безпеки й оборони, які схвалюються Радою національної безпеки і оборони України і затверджуються указами Президента України [10]. Варто відзначити підхід, обгрунтований у докторському дослідженні Л.О. Золотухіною, основою якого є розуміння сфер реалізації публічного інтересу як сфер забезпечення вимог національної безпеки. Тобто напрямами реалізації публічного інтересу у сфері національної безпеки є воєнна, зовнішньополітична, державна, економічна, інформаційна, екологічна безпеки, кібербезпека України [12, с. 148-150].

Визначення сутності екологічної безпеки як складника системи національної безпеки має певну історію становлення. Необхідно відзначити, що перші звернення до необхідності здійснення досліджень з питань визначення сутності екологічної безпеки як складника національної безпеки пов' язуються із серединою 90-х років минулого століття, коли усвідомлення незалежності держави потребувало методологічного і методичного забезпечення формування політики національної безпеки, вивчення засад національної безпеки як системного багатокомпонентного явища й однієї з фундаментальних основ державотворення [13, с. 243].

Забезпечення вимог екологічної безпеки як складника національної безпеки передусім пов' язується із ужиттям заходів із запобігання надзвичайних екологічних ситуацій, подоланням проявів екологічної злочинності, попередженням інших форм правопорушень у сфері використання природних ресурсів, що у сукупності визначають ефективність здійснення державної політики із забезпечення екологічних прав особи.

Дослідження проблем забезпечення вимог екологічної безпеки як складника національної вимоги належить до міжгалузевої проблематики, що обгрунтовує доцільність виділення ряду наукових розробок, здійснених у межах еколого-правової науки. Зокрема, на теренах вітчизняної юридичної науки одним із перших свої наукові дослідження проблематиці екологічної безпеки присвячували такі вчені, як B.I. Андріейцев [13, с. 24-26; 14, с. 8-11], який в основу розуміння такої категорії покладав необхідність усунення екологічних ризиків. У дослідженні Ю.С. Шемшученка, В.Ф. Погорілка було вперше приділено увагу оптимізації адміністративно-правового механізму забезпечення права людини на безпечне довкілля [15]. Зокрема, Ю.С. Шемшученко визначає, що запровадження та оптимізація адміністративно-правового механізму забезпечення вимог екологічної безпеки належить до ефективних засобів реалізації природоохоронної політики держави, забезпечення іiі дії [15, с. 56-60].

Однак, попри актуалізацію проблеми забезпечення вимог екологічної безпеки, сучасний стан охорони довкілля в Україні є доволі критичним. Знищення навколишнього природного середовища відбувається внаслідок вирубування лісів, розорювання земель 3 подальшою зміною їх цільового призначення, осушення або обводнення територій, що своєю чергою негативно відбивається на житті і здоров'ї суспільства. Збільшення антропогенного технічного навантаження негативно впливає на рівень тривалості життя людей у країні, що у декілька разів перевищує показники в інших розвинених державах світу.

Вищезазначена аргументація є основою для формування публічних екологічних інтересів, що вимагають створення дієвого адміністративно-правового механізму їх 
забезпечення та захисту. Реалізація публічних екологічних інтересів вимагає належного здійснення державної політики із впровадження екологічної функції, що має грунтуватися положеннями концепції «виключного права власності Українського народу» та конституційного права людини на безпечне довкілля (ст.ст. 13, 14, 50 Конституції України) [16].

Реалізація екологічної функції держави, як зазначає Ю.О. Легеза, має спрямовуватися на розпорядження в інтересах суспільства використання природних ресурсів, спрямовану на забезпечення раціонального користування ними з метою попередження їх виснаження й деградації якості довкілля, а також охорони екологічних прав та інтересів громадян. Вона полягає в забезпеченні збалансованого співвідношення екологічних та економічних інтересів соціуму, публічних і приватних екологічних інтересів, пов'язаних з наданням необхідних гарантій для реалізації та захисту прав людини на безпечне для життя навколишнє природне середовища [17, с. 95-101]. В.В. Петров визначає екологічні інтереси як об'єктивно існуючі потреби людини в чистому, здоровому, продуктивному навколишньому природному середовищі, що забезпечує біологічний режим життя [18, с. 557], таким чином ототожнюючи екологічні потреби та екологічні інтереси.

Натомість О.С. Карпова у своїх наукових розробках підкреслює недоцільність у проведенні еквівалентних зав'язків між екологічними потребами та екологічними інтересами, визначаючи їх як категорії, що співвідносяться як зміст та форма [19]. Вартою уваги є позиція В.С. Шахова, який розуміє категорію екологічного інтересу як об'єктивно зумовленого ставлення суб'єктів права до своїх екологічних потреб та умов життя, що мають забезпечувати їм належну життєдіяльність та екологічну рівновагу в навколишньому природному середовищі. Реалізація екологічних інтересів пов' язується не лише із реалізацією державної політики із охорони довкілля, але і з забезпеченням інтенсивного користування природними об'єктами для сталого економічного й соціального розвитку соціуму [20, с. 214]. Поглиблюються наявні дослідження категорії «екологічний інтерес» у роботах М.І. Васильєвої, де екологічний інтерес розглядається як публічно-правовий вимір змісту суб'єктивного права громадян на безпечне довкілля. Вчена підкреслює при цьому, що інтерес виступає виключно як публічний. У дослідженнях М.I. Васильєвої підкреслюється пріоритетність забезпечення екологічних інтересів як складника системи суб'єктивних публічних прав приватної особи, наголошується, що їх реалізація має безпосередній вплив на якість життя та здоров'я людини, іiі майбутніх поколінь, сприяє справедливому розподілу благ, які отримуються від використання природних ресурсів, становлять основу діяльності населення країни, які збалансовані з потребами економічного зростання, опосередковані правом, охороняються й гарантуються державою [21, с. 15].

У Законі України «Про охорону навколишнього природного середовища» закріплено ряд суб'єктивних публічних екологічних прав, до яких належить і право на вільний доступ до інформації про стан довкілля, і право об'єднуватись у громадські природоохоронні формування, й право на одержання екологічної освіти та інші [22].

Об'єктивізація публічного екологічного інтересу пов'язується із його виникненням до моменту набуття повної правосуб'єктності учасником правовідносин та усвідомленням ним соціальної значущості ефективності його реалізації.

Висновки. Отже, на підставі здійсненого дослідження під суб'єктивним публічним екологічним правом приватної особи необхідно розуміти визначену чинним законодавством можливість участі приватної особи у реалізації природоохоронної (екологічної) функції держави. Змістом суб'єктивного публічного екологічного права є задоволення соціального інтересу у запобіганні виникнення надзвичайних екологічних 
ситуацій, забезпечення раціонального використання природних ресурсів загальнодержавного та місцевого значення, що своїм результатом має зростання рівня якості життя та здоров'я людини. Видами суб'єктивних публічних екологічних прав є і право на вільний доступ до інформації про стан довкілля, і право об'єднуватись у громадські природоохоронні формування, й одержання екологічної освіти тощо.

\section{Список використаних джерел:}

1. Мацелик Т.О. Суб'єктивне публічне право як юридичний феномен. Юридичний вісник. 2011. № 3. С. 67-71.

2. Федосенко В. А. Субъективные права у публичной сфере : дис. . канд. юрид. наук : 12. 00. 01. Москва, 2007. 28 с.

3. Коркунов Н.М. Лекции о общей теории права. С. Петербург, 1909. 354 с.

4. Синявська О.Ю. Суб'єктивні публічні права приватної особи. Право $і$ безпека. 2010. № 2. С. 52-55.

5. Матузов Н.И., Малько А.В. Теория государства и права : учебник. Москва : Юристъ, 2004. С. 78-79.

6. Заверуха О. Суб'єктивні публічні права як об'єкт судового захисту. Право України. 2004. № 4. C. 49-52.

7. Greve M.S. The Non-Reformation of Administrative Law: Standing to Sueand Public Interest Litigation in West German Environmental Law. Cornell International Law Journal. 1989. Vol. 22. P. 197-244.

8. Шерстобоев О.Н. Теория интересов в административно-правовом измерении. Российский юридический журнал. 2014. № 3. С. 99-108.

9. Мельник Р.С., Бевзенко В.М. Загальне адміністративне право : навч. посіб. / за ред. Р.С. Мельника. Київ : Ваіте, 2014. 376 с.

10. Про національну безпеку України: Закон України від 21 червня 2018 р. № 2469-VIII. Відомості Верховної Ради (ВВР). 2018. № 31. Ст. 241.

11. Золотухіна Л.О. Публічний інтерес як адміністративно-правова категорія : дис. ... д.ю.н. 12.00.07. Запоріжжя : ЗНУ, 2019. 486 с.

12. Сабіров Р.Ф. Екологічна безпека як невід'ємна складова національної безпеки України. Вісник Луганського державного університету внутрішніх справ імені Е.О. Дідоренка. 2010. № 1. С. 240-245.

13. Андрейцев B.I. Право екологічної безпеки: Навчальний та науково-практичний посібник. Київ : Знання-Прес, 2002. 332 с.

14. Андрейцев B.I. Право громадян на екологічну безпеку: проблеми конституційно-правового забезпечення. Право Украӥни. 2001. № 4. С. 8-11.

15. Шемшученко Ю.С., Погорілко В.Ф. Адміністративно-правова охорона природи Української РСР. Київ : Наук. думка, 1973. 128 с.

16. Конституція України від 28 червня 1996 року. Відомості Верховної Ради України. 1996. № 30. Ст. 141.

17. Легеза Ю. О. Визначення змісту екологічної функції держави. Науковий вісник Дніпроп. держ. ун-ту внутр. справ. 2012. № 1. С. 95-101.

18. Петров В.В. Экологическое право России : учеб. / В.В. Петров. Москва : БЕК, 1997. 557 c.

19. Карпова О. С. Юридична природа категорії «публічний екологічний інтерес». Теорія і практика правознавства. 2014. Вип. 1 (5). URL: http://irbis-nbuv.gov.ua/cgibin/irbis_nbuv/cgiirbis_64.exe?C21COM=2\&I21DBN=UJRN\&P21DBN=UJRN\&IMAGE_ FILE_DOWNLOAD=1\&Image_file_name=PDF/tipp_2014_1_15.pdf.

20. Шахов В. С. Екологічні інтереси і права людини. Правова держава Україна: проблеми, перспективи розвитку : короткі тези допов. та наук. повідом. республ. наук.-пр- 
акт. конфер., 9-11 листоп. 1995 р. Харків : Нац. юрид. акад. України ім. Я. Мудрого, 1995. C. 214-215.

21. Васильева М. И. Публичные экологические интересы: проблемы теории. Экологическое право. 2004. № 4. С. 12-20.

22. Про охорону навколишнього природного середовища : Закон України від 25 червня 1991 р. № 41. URL: http:/ / zakon4.rada.gov.ua/laws/show/1264-12. 
УДК 342.9(477)

DOI https:/ / doi.org/10.32850/LB2414-4207.2020.14.19

\title{
ПРАКТИКА ВЕРХОВНОГО СУДУ ТА ЄВРОПЕЙСЬКОГО СУДУ 3 ПРАВ ЛЮДИНИ У СФЕРІ ПРАВОВОГО РЕГУЛЮВАННЯ МИТНИХ ВІДНОСИН
}

\author{
Лемеха Ростислав Ігорович, \\ кандидат юридичних наук, \\ здобувач наукового ступеня доктора \\ юридичних наук \\ (Запорізький національний \\ університет, \\ м. Запоріжжя, Україна)
}

У науковій публікації досліджується практика Верховного Суду та Свропейського суду з прав людини у сфері правового регулювання митних відносин. Зазначається, що юридичні спори у сфері митних відносин між суб'єктами зовнішньоекономічної діяльності й органами публічної адміністрації в особі Державної митної служби України розглядаються адміністративними судами, у зв'язку із чим важливе дослідження правових висновків Касаційного адміністративного суду в складі Верховного Суду у сфері правового регулювання митних відносин.

Підкреслюється важливість виконання рішень Свропейського суду з прав людини й вжиття заходів загального характеру з метою недопущення порушень європейської Конвенції про захист прав людини й основоположних свобод.

Пропонується висновок про те, що в Україні поступово формується прецедентне право. Не зважаючи на належність національної правової системи до романо-германської правової сім'ї, правові висновки (позищіï) Верховного Суду й рішення Свропейського суду 3 прав людини відіграють все більшу роль в юридичній практиці й прямо впливають на результати правозастосування органів публічної адміністрації та судів. Проаналізовані постанови Касаційного адміністративного суду в складі Верховного Суду. Рішення Свропейського суду з прав людини у сфері правового регулювання митних відносин свідчать про важливість казуального тлумачення норм митного права для правильного розуміння та застосування норм Митного кодексу України й інших нормативно-правових актів.

Ключові слова: митні відносини, митне право, прецедент, Верховний Суд, конвенція, права людини, тлумачення, правозастосування, публічна адміністрація, заходи, рішення, постанови.

\section{PRACTICE OF THE SUPREME COURT AND THE EUROPEAN COURT OF HUMAN RIGHTS IN THE AREA OF REGULATION OF THE CUSTOMS RELATIONS}

\author{
Lemekha Rostyslav Ihorovych, \\ Candidate of Juridical Sciences, \\ Doctoral Student in Juridical Sciences \\ (Zaporizhzhia National University, \\ Zaporizhzhia, Ukraine)
}

The scientific publication is devoted to the practice of the Supreme Court and the European Court of Human Rights in the field of legal regulation of customs relations. It is noted 
that legal disputes in the field of customs relations between economic entities and public administration bodies represented by the State Customs Service of Ukraine are considered by administrative courts, in connection with which it is important to study the legal conclusions of the Administrative Court of Cassation as part of the Supreme Court.

The methodology of this study is based on a complex combination of philosophical, general scientific (methods of logical method, system and structural-functional methods) and special legal research methods (method of legal dogma, method of legal modeling, methodology of comparative law, etc.), principles of objectivity and historicism.

The importance of implementing the judgments of the European Court of Human Rights and taking measures of a general nature in order to prevent violations of the European Convention for the Protection of Human Rights and Fundamental Freedoms is emphasized.

The theoretical and practical significance of this study is based on the fact that the analyzed decisions of the Supreme Court and the European Court of Human Rights in the field of customs relations are the basis for correct interpretation and application of customs law in national legal practice (in administrative cases and in administrative practice State Customs Service of Ukraine), as well as to formulate proposals for improving the current and future national legislation.

The conclusion is formulated that case law is gradually being formed in Ukraine. Despite the fact that the national legal system belongs to the Romano-Germanic legal family, the legal conclusions (positions) of the Supreme Court and decisions of the European Court of Human Rights play an increasing role in legal practice and directly affect the enforcement of public administration and courts. Analyzed decisions of the Administrative Court of Cassation of the Supreme Court and the decision of the European Court of Human Rights in the field of legal regulation of customs relations indicate the importance of casual interpretation of customs law for proper understanding and application of the Customs Code of Ukraine and other regulations.

Key words: customs relations, customs law, precedent, Supreme Court, convention, human rights, interpretation, law enforcement, public administration, measures, decisions, resolutions.

Вступ. Національне законодавство досить детально регулює митні відносини, враховуючи їх важливість для національної економіки та правової системи. Проте, на практиці часто виникають питання, які прямо не врегульовані нормами митного права й викликають неоднозначні тлумачення щодо порядку їх розв'язання. У випадку наявності спору про право, справа розглядається відповідним адміністративним судом, адже митні відносини - це, як правило, публічно-правові відносини між суб'єктами зовнішньоекономічної діяльності та органами публічної адміністрації в особі Державної митної служби України. У зв' язку із цим важливим є дослідження правових висновків (позицій) Касаційного адміністративного суду у складі Верховного Суду у сфері правового регулювання митних відносин. В подальшому, після використання всіх національних засобів захисту порушеного права особа має право звернутись до Європейського суду з прав людини. Це право гарантується ст. 55 Конституції України. Крім того, у відповідності до ст. 17 Закону України «Про виконання рішень та застосування практики Європейського суду 3 прав людини»національні суди застосовують при розгляді справ європейську Конвенцію про захист прав людини і основоположних свобод та практику Європейського суду 3 прав людини як джерело права. Таким чином, рішення Свропейського суду з прав людини, які по суті є судовими прецедентами, є джерелом права для національних судів, проте виникає питання щодо обов' язковості їх врахування в національній юридичній практиці. 3 одного боку, із тексту згаданого закону випливає, що рішення Європейського суду 3 прав людини мають не обов'язковий, рекомендаційний характер для національ- 
них судів. Але з іншого боку, у випадку ігнорування правової позиції, яка викладена в рішенні Свропейського суду з прав людини, національний суд створює умови для звернення громадянина до такої міжнародної судової установи та фактично спонукає людину до цього. Як наслідок, Європейський суд з прав людини, посилаючись на свою правову позицію, задовольняє таку заяву та зобов'язує Україну усунути порушення права та виплатити особі справедливу сатисфакцію. Отже, національні суди та інші суб'єкти правозастосування (органи публічної адміністрації), включаючи посадових осіб Державної митної служби України, повинні враховувати положення Конвенції про захист прав людини та основоположних свобод, а також прецедентну практику Свропейського суду з прав людини у свойй судовій та адміністративній практиці 3 метою запобігання порушенням прав і свобод людини. Враховуючи специфічність митних спорів, пов' язаних більшою мірою із зовнішньоекономічною діяльністю, кількість справ, розглянутих Європейським судом з прав людини у цій сфері суспільних відносин, є незначною, проте це не зменшує важливість окремого наукового дослідження практики Європейського суду з прав людини у сфері митних відносин. Відсутність окремих досліджень такої тематики актуалізує необхідність такої публікації.

Теоретична й практична значимість такого дослідження обгрунтовується тим, що проаналізовані рішення Верховного Суду та Свропейського суду з прав людини у сфері митних відносин є основою для правильного тлумачення та застосування норм митного права в національній юридичній практиці (в процесі розгляду відповідних справ адміністративними судами та в адміністративній практиці Державної митної служби України), а також для формулювання пропозицій щодо удосконалення чинного та формування перспективного національного законодавства.

Питання адміністративно-правового регулювання митних відносин в Україні досліджуються в роботах фахівців у сфері адміністративного права, серед яких роботи О. Бандурки, В. Бевзенка, Н. Білак, М. Віхляєва, Н. Губерської, С. Гусарова, Р. Калюжного, Т. Коломоєць, В. Колпакова, А. Комзюка, О. Кузьменко, В. Курила, Д. Лук'янця, Д. Лученка, П. Лютікова, М. Мельника, Р. Мельника, О. Миколенка, Я. Назарової, Н. Нижник, Д. Приймаченка, С. Стеценко, М. Тищенка, О. Чуприни, А. Школика й інших вчених-адміністративістів. 3 останніх досліджень слід відзначити дисертаційні роботи М. Мельника «Інститут митних режимів в митному праві України» [1], Н. Білак «Особливості переміщення об'єктів інтелектуальної власності через митний кордон України» [2], Я. Назарової «Правове регулювання митних режимів тимчасового ввезення та тимчасового вивезення» [3], О. Чуприни «Правове регулювання митних режимів переробки» [4] та його наукову публікацію «Класифікація митних режимів у юридичній науці та законодавстві» [5]. Проте, практика Верховного Суду та Свропейського суду з прав людини у сфері правового регулювання митних відносин досліджена фрагментарно, більшою мірою в рамках більш загальних тем, що актуалізує проведення дослідження.

Методологія дослідження грунтується на комплексному поєднанні філософських, загальнонаукових (прийомів логічного методу, системного та структурно-функціонального методів) та спеціально-юридичних методів дослідження (методу юридичної догматики, методу юридичного моделювання, методології порівняльного правознавства тощо), принципів об'єктивності та історизму.

Постановка завдання. Метою наукової публікації є дослідження практики Верховного Суду та Свропейського суду з прав людини у сфері правового регулювання митних відносин, зокрема щодо правових засад митних режимів.

Результати дослідження. Закони та підзаконні нормативно-правові акти в силу своєї правової природи мають абстрактний характер і містять правила поведінки 
загального характеру. В той же час юридична практика мінлива, кожна юридична справа унікальна, що викликає необхідність казуального тлумачення норм законів, яке здійснюють органи публічної адміністрації та суди. Норми митного права також часто потребують казуального тлумачення, адже митні відносини є відносинами між суб'єктами зовнішньоекономічної діяльності та органами публічної адміністрації в особі Державної митної служби України. Приватний інтерес максимально вигідно перемістити товар чи транспортні засоби через митних кордон України стикається з публічним інтересом захистити національну економіку від недоброякісної та несертифікованої продукції та максимально поповнити державний бюджет, чим обумовлені достатньо часті спори про право в такій сфері суспільних відносин. Враховуючи публічно-правовий характер митних відносин юридичні спори у сфері митної справи розглядають відповідні адміністративні суди. Важливу роль в тлумаченні норм митного права відіграє вища судова інстанція України. Постанови Верховного суду містять правові позиції, які зобов'язані враховувати у своїй практиці суди нижчих інстанцій. Такий обов' язок випливає із положення ч. 5 ст. 242 Кодексу адміністративного судочинства (далі - КАС) України, згідно з яким «при виборі і застосуванні норми права до спірних правовідносин суд враховує висновки щодо застосування норм права, викладені в постановах Верховного Суду» [6].

Таким чином, враховуючи по суті прецедентний характер постанов Верховного Суду, можна говорити про повноцінну судову правотворчість в Україні, результати якої мають все більше значення для правильного розуміння та застосування норм матеріального та процесуального права органами публічної адміністрації та судами нижчих інстанцій.

Так, наприклад, Касаційний адміністративний суд у складі Верховного суду розмежував поняття «митний контроль» та «митне оформлення» (Постанова Верховного Суду від 18 січня 2018 р. у справі № 807/3168/14). У вказаній справі позивач оскаржував дії працівників митного поста щодо проведення переогляду транспортного засобу з вантажем та його затримки через проведення додаткових перевірочних заходів [7].

Верховний Суд у складі колегії суддів Касаційного адміністративного суду вважає помилковими доводи скаржника, що митний контроль $є$ складовою частиною митного оформлення при переміщенні товарів, транспортних засобів через митний кордон України, оскільки ці дві правові категорії - митний контроль та митне оформлення - відрізняються за своїм змістом та являють собою два різні процеси, які мають свої власні системні характеристики.

Так, відповідно до ст. 4 Митного кодексу України, митне оформлення - це виконання митних формальностей, необхідних для випуску товарів, транспортних засобів комерційного призначення. Митний контроль - сукупність заходів, що здійснюються 3 метою забезпечення додержання норм цього Кодексу, законів та інших нормативно-правових актів $з$ питань державної митної справи, міжнародних договорів України, укладених у встановленому законом порядку [8].

Згідно з приписами ст. 321 Митного кодексу України товари, транспортні засоби комерційного призначення перебувають під митним контролем з моменту його початку і до закінчення згідно із заявленим митним режимом. У разі вивезення товарів, транспортних засобів комерційного призначення за межі митної території України митний контроль закінчується після здійснення їх митного оформлення та перетинання ними митного кордону України, за винятком митних режимів, які передбачають перебування під митним контролем протягом усього часу дії митного режиму [8].

На підставі наведених норм колегія суддів дійшла висновку, що під митним контролем товари, транспортні засоби комерційного призначення перебувають 
з моменту заявлення митного режиму (шляхом подання митної декларації) до фактичного перетинання ними митного кордону України (отримання дозволу від митного органу) [7].

Таким чином, навіть після завершення митного оформлення товару, яке в цьому випадку було здійснено на внутрішньому митному посту, митні органи у пункті пропуску на митному посту уповноважені були здійснювати митний контроль товару шляхом проведення передбачених Митним кодексом України контрольно-перевірочних заходів до фактичного перетинання таким товаром митного кордону України.

Водночас на підставі викладеного суд касаційної інстанції зазначає, що суди першої та апеляційної інстанцій при обгрунтуванні рішень помилково виходили з того, що митний контроль містить також митне оформлення, оскільки ці правові категорії не співвідносяться як загальне та окреме, проте це не вплинуло на правильність прийнятих судових рішень у зазначеній справі [7].

Заслуговує на увагу практика Верховного Суду щодо спорів, що виникають при визначенні митними органами вищої ціни товарів, ніж заявляється імпортерами при ввозі товару в Україну.

Як зазначає А. Паркулаб, лише з моменту вступу в силу нових процесуальних кодексів (15 грудня 2017 р.) по 17 листопада 2019 р. судами розглянуто приблизно 3000 справ, в яких оскаржуються рішення митниць про коригування митної вартості. Верховним Судом розглянуто приблизно 400 касаційних скарг із такої категорії справ [9].

Передумовою спорів, на думку А. Паркулаба, є як недосконалість Митного кодексу, так і постійні намагання уряду в ручному режимі збільшувати надходження до бюджету з митниць шляхом запровадження негласних індикативних цін, «таблиць», профілів ризику тощо. Оскільки таке ручне регулювання несумісне з положеннями Митного кодексу, на рівні Верховного Суду сформувалась переважно позитивна практика для імпортерів. Виключенням стала постанова Верховного Суду від 30 жовтня 2018 р. по справі №816/2396/17.

Зазвичай обставини справ, в яких розглядається правомірність рішень про коригування митної вартості, є типовими і повторюються від справи до справи. Імпортер заявляє до митного оформлення товар, вартість якого визначає за першим методом (за ціною контракту). Митний орган з тих чи інших підстав не визнає заявлену митну вартість, приймає рішення про коригування митної вартості і відмовляє в митному оформленні за заявленою митною вартістю. Далі у імпортера, який не згоден з прийнятими рішеннями, але бажає все ж таки якнайшвидше отримати товари, є два варіанти дій: самостійно сплатити митні платежі з ціни, визначеної митним органом, і в подальшому, в разі скасування рішень, вимагати їх повернення, або надати фінансові гарантії сплати різниці митних платежів між ціною, визначеною імпортером, і ціною, визначеною митним органом. У фінансових гарантій є два істотні недоліки: ïx можуть видавати тільки уповноважені і внесені до реєстру гарантів юридичні особи (лише п'ять гарантів в реєстрі станом на 16 липня 2019 р.), а максимальний строк гарантії складає 90 днів. Якщо за 90 днів рішення про коригування митної вартості не скасовується, імпортер вимушений сплатити різницю митних платежів [9].

А. Паркулаб зазначає, що отримати за 90 днів рішення суду про скасування рішення про коригування митної вартості, яке набрало законної сили, не вбачається можливим навіть теоретично. У зв' язку із цим, у більшості випадків після відмови у митному оформленні за заявленою ціною імпортери подають нову митну декларацію з ціною, визначеною митним органом, сплачують різницю митних платежів, а далі вже оскар- 
жують рішення про коригування митної вартості, і в разі успіху повертають різницю. Те, яким чином імпортер здійснював митне оформлення після прийняття рішення, не мало жодного значення при вирішенні питання щодо правомірності рішень про коригування митної вартості товарів підчас судового розгляду, і ніколи особливо не цікавило суди. Але, в постанові Верховного Суду від 30 жовтня 2018 р. по справі № 816/2396/17 суд висловив новий погляд на звичні речі. Згідно з вказаним рішенням, подання нової митної декларації з ціною, визначеною митним органом, свідчить про згоду декларанта з такою ціною, а відтак правовий спір між сторонами вичерпано внаслідок погодження декларанта із митною вартістю, визначеною митним органом, і у задоволенні позову про скасування рішення про коригування митної вартості слід відмовити. Єдиним варіантом поведінки, яка свідчить про незгоду декларанта 3 визначеною митним органом вартістю та надає можливість в подальшому оскаржувати рішення в суді, за позицією суду, залишається надання фінансових гарантій відповідно до ч. 7 ст. 55 Митного кодексу [9].

Таким чином, Верховний Суд у вказаному рішенні відступив від усталеної судової практики. В той же час, факти відступу судів нижчих інстанцій від правових позицій Верховного Суду за усталеною практикою зустрічаються не часто, адже в такому випадку зацікавлена особа звертається до вищих судових інстанцій та в більшості випадків отримує рішення на свою користь, посилаючись на сформовані правові позиції Верховного Суду.

Проте, трапляються ситуації, коли особа не задоволена рішенням національних судів і вважає своє право порушеним. В такому випадку суб'єкт має гарантоване Конституцією України та європейською Конвенцією про захист прав людини та основоположних свобод право звернутися до міжнародної судової установи, а саме Європейського суду 3 прав людини. Так, згідно із ч. 2 ст. 55 Конституції України, «кожен має право після використання всіх національних засобів юридичного захисту звертатися за захистом своїх прав і свобод до відповідних міжнародних судових установ чи до відповідних органів міжнародних організацій, членом або учасником яких є Україна» [10].

Європейський суд з прав людини є конвенційним органом, який здійснює свою діяльність на підставі європейської Конвенції про захист прав людини та основоположних свобод, яка ратифікована Україною. Його рішення не $є$ обов'язковими для національних судів, проте обов’язковими є рішення Свропейського суду з прав людини щодо виплати справедливої сатисфакції заявнику, права якого порушено державою-відповідачем.

Як справедливо зазначає О. Давидчук, саме поняття виконання рішення Свропейського суду з прав людини звісно не обмежується питанням виплати відшкодування за завдану заявникові матеріальну та(або) нематеріальну шкоду. Те чи інше рішення з констатацією порушення положень Конвенції передбачає необхідність вжити заходи індивідуального та загального характеру. Необхідно також зазначити, що виплата справедливої сатисфакції є складовою частиною заходів індивідуального характеру. Зокрема у справі «Скоциарі і Гінта проти Imaлї» Суд зазначив, що Високі Договірні Сторони взяли на себе обов' язок виконувати остаточні рішення Свропейського суду у будь-якій справі, в якій вони є сторонами, і виконання цих рішень здійснюється під контролем Комітету Міністрів Ради Свропи. 3 цього слідує, inter alia, що рішення, відповідно до якого Європейський суд визнав порушення, покладає на державу-відповідача обов' язок не лише здійснити на користь заявника виплати, присуджені у якості справедливої сатисфакції, але також і здійснити під контролем Комітету Міністрів загальні, i, якщо це доречно, індивідуальні заходи, здійснення яких є необхідним в рамках внутрішньої правової системи, аби покласти край виявленому порушенню 
та виправити негативні наслідки такого порушення. Більше того, знаходячись під контролем Комітету Міністрів, держава-відповідач вільна у виборі засобів, якими вона виконуватиме свої зобов' язання за ст. 46 Конвенції, за умови, що такі засоби не суперечитимуть висновкам, які містяться у рішенні Європейського суду [11].

У сфері правового регулювання митних відносин Європейський суд 3 прав людини приймає рішення не часто, адже в рамках Європейського Союзу діє свобода переміщення товарів і транспортних засобів через внутрішні митні кордони держав-членів ЄС. Серед найбільш актуальних, що були прийнятті достатньо недавно, слід виділити такі.

Перше, рішення Європейського суду з прав людини у справі «Садоха проти України» (Заява № 77508/11) від 11 липня 2019 р., яке набуло статус остаточного 11 жовтня 2019 р. У вказаній справі заявник скаржився на те, що конфіскація його отриманих законним шляхом коштів була надмірним і непропорційним заходом, та що його не було належним чином викликано у судові засідання у його справі [12].

22 липня 2011 р. заявник подорожував з аеропорту «Київ» (Жуляни) до Польщі. Він пройшов через «зелений коридор», перевозячи 41000 євро готівкою у ручній поклажі. Під час контролю на безпеку його ручну поклажу було проскановано. Згідно 3 твердженнями заявника, як тільки працівник служби авіаційної безпеки запитав його, чи перевозив він будь-яку готівку, заявник повідомив, що в його ручній поклажі були гроші й показав їх працівнику служби авіаційної безпеки. Згідно зі складеним на місці Державною митною службою України протоколом про порушення митних правил заявник порушив процедури митного контролю у зоні спрощеного митного контролю, перевозячи товари (готівку), які підлягали обов'язковому декларуванню та письмово не задекларував суму грошей, яку перевозив, у повному обсязі. Йому пред'явили обвинувачення в порушенні ст. ст. 339 і 340 Митного кодексу України. Працівник митниці вилучив 31000 євро як предмет правопорушення, дозволивши заявнику залишити решту 10000 євро [12].

10 серпня 2011 р. Солом' янський районний суд міста Києва встановив, що протокол про порушення митних правил був достатнім доказом правопорушення, та ухвалив постанову про конфіскацію суми у розмірі 31000 євро.

Проаналізувавши доводи заявника та представника Уряду України, Свропейський суд 3 прав людини зазначив, що немає жодних доказів, які підтверджують спричинення заявником якоїсь серйозної шкоди державі: він не ухилявся від сплати мита або будь-яких інших зборів і не завдав державі будь-якої іншої матеріальної шкоди. Твердження, яке містилося у постанові апеляційного суду про те, що дії заявника завдали «істотної шкоди зовнішньоекономічним інтересам і безпеці України», є занадто нечітким і загальним та не є підтвердженим іншими деталями щодо того, у чому саме полягала ця шкода. Тому Суд вважає, що стягнення у вигляді конфіскації не було направлено на відшкодування матеріальної шкоди, оскільки держава не зазнала жодних втрат внаслідок недекларування заявником коштів, а було стримуючим та каральним за своїм призначенням. Крім того, Суд вважає, що межі проведеного національними судами розгляду справи були занадто вузькими, щоб відповідати вимозі встановлення «справедливого балансу», притаманній другому абзацу ст. 1 Першого протоколу до Конвенції. За цих обставин конфіскація незадекларованих коштів у повному обсязі, на думку Суду, поклала індивідуальний і надмірний тягар на заявника та була непропорційною вчиненому правопорушенню. Отже, було порушено ст. 1 Першого протоколу до Конвенції [12].

Таким чином, Свропейський суд з прав людини врахував дискреційні повноваження національних судів та зазначив, що підставою для встановлення порушення 
ст. 1 Першого протоколу до європейської Конвенції про захист прав людини та основоположних свобод у цій справі був непропорційний характер накладеного на заявника стягнення, що не означає, що заявник не повинен був нести жодної відповідальності за вчинене ним порушення національного законодавства.

Друге, рішення Європейського суду з прав людини у справі «Мякотін проти України» (Заява № 29389/09) від 17 грудня 2019 р. Згідно з матеріалами справи заявник стверджував про порушення ст. 1 Першого протоколу до Конвенції у зв' язку з конфіскацією його автомобіля за стверджуване порушення митних правил. 22 червня 2007 р. заявник отримав видану іспанськими органами влади посвідку на постійне проживання, дійсну до 18 червня 2009 р. Він зазначив, що на момент подій проживав в Іспанії. 30 квітня 2008 р. заявник перетнув кордон України з Польщею на митному посту «Краковець». Він їхав на купленому в Іспанії автомобілі «Опель Вектра». Під час проходження митного контролю заявник зазначив, що постійно проживав в Іспанії та приїхав до України для продовження навчання. У митній декларації заявник також вказав, що проживав в Іспанії. Для підтвердження своєї заяви заявник надав посвідку на постійне проживання в Іспанії. Працівник митниці Т. вирішив, що заявнику, як резиденту Іспанії, було дозволено тимчасово до 30 червня 2008 р. ввезти автомобіль на митну територію України без сплати ввізного мита [13].

05 червня 2008 р. заявника зупинили працівники ДАІ і 27 червня 2008 р. було складено протокол про адміністративне правопорушення. Було зроблено висновок, що заявник порушив митні правила, оскільки він мав вважатися резидентом України, і тому мав сплатити за свій автомобіль 56 394,40 українських гривень (приблизно 5000 євро на момент подій) митних зборів. 10 листопада 2008 р. Бердянський міськрайонний суд, посилаючись на ст. 38 Кодексу України про адміністративні правопорушення та ст. ст. 322 і 328 Митного кодексу України, закрив провадження у справі заявника у зв'язку із закінченням строку давності, проте зобов'язав конфіскувати автомобіль заявника.

За результатами розгляду зазначеної справи Європейський суд з прав людини зазначив, що заявника було покарано за ухилення від сплати ввізного мита через подання нібито неправдивих відомостей в митній декларації щодо його статусу резидента. Проте вбачається, що одним із головних питань, які оскаржуються у цій справі, було визначення того, чи дійсно заявник був резидентом України, чи ні. Суд зазначив, що органи державної влади дійшли такого висновку на тій підставі, що постійне місце проживання заявника було зареєстроване в Україні і в його паспорті не було штампу «постійне проживання». У зв' язку з цим Європейський суд з прав людини зауважив, що питання полягає в тому, чи було чинне на той момент відповідне законодавство достатньо передбачуваним, щоб заявник, який проживав в Іспанії на законних підставах, правильно визначив своє місце проживання для цілей митного декларування, а саме - зробив висновок, що відсутність у паспорті штампу «постійне проживання» та реєстрація його місця проживання в Україні не дозволять йому вказати в митній декларації, що його постійне місце проживання було в Іспанії [13].

Суд також зазначив, що ніщо не свідчить про те, що заявник ввозив заборонені товари, коли-небудь обвинувачувався у скоєнні інших злочинів, пов'язаних з порушенням митних правил, або володів автомобілем незаконно. Насамкінець Суд зазначив, що формулювання ст. 351 Митного кодексу України (чинного на момент подій), за якою заявника було визнано винним, надало національним судам певну свободу розсуду щодо накладання стягнень. Зокрема, вона передбачала, що заборонені дії $\epsilon$ підставою для накладення штрафу, конфіскації товарів, у тому числі конфіскації транспортних засобів. Проте враховуючи, що на момент розгляду справи заявника 
строки для накладення інших стягнень, окрім конфіскації, закінчилися, відповідно до ст. ст. 322 і 328 Митного кодексу України національні суди могли накласти лише стягнення у вигляді конфіскації. На думку Суду, звуження вибору санкцій до стягнення у вигляді конфіскації без встановлення жодних строків руйнує саму суть необхідного справедливого балансу між вимогами загального інтересу та захистом права особи на власність. За цих обставин, беручи до уваги зазначені міркування у сукупності, Суд дійшов висновку, що оскаржувана конфіскація була непропорційною скоєному правопорушенню, а тому поклала на заявника надмірний тягар. Таким чином, на підставі аналізу національного законодавства, Конвенції та доводів сторін, Свропейський суд 3 прав людини встановив, що автомобіль було конфісковано у заявника всупереч ст. 1 Першого протоколу до Конвенції [13].

Таким чином, Свропейський суд з прав людини звернув увагу на необхідність дотримання органами публічної адміністрації України принципу правової визначеності, а також дотримання справедливого балансу між вимогами загального інтересу та захистом права особи на власність.

Проаналізовані рішення Європейськогосудузправ людиниєпоказовими та повинні стати підставою для вжиття заходів загального та індивідуального характеру, спрямованих на усунення причин порушення європейської Конвенції про захист прав людини та основоположних свобод у сфері правового регулювання митних відносин.

Висновки. Дослідження практики Верховного Суду та Європейського суду з прав людини у сфері митних відносин дозволяє зробити висновок про те, що в Україні поступово формується прецедентне право. Не зважаючи на належність національної правової системи до романо-германської правової сім'ї, правові висновки (позиціiі) Верховного Суду та рішення Свропейського суду з прав людини відіграють все більшу роль в юридичній практиці та прямо впливають на результати правозастосування органів публічної адміністрації та судів. Проаналізовані постанови Касаційного адміністративного суду у складі Верховного Суду та рішення Європейського суду з прав людини у сфері правового регулювання митних відносин свідчать про важливість казуального тлумачення норм митного права для правильного розуміння та застосування норм Митного кодексу України та інших нормативно-правових актів.

Перспективність подальшого дослідження такої тематики обумовлена активною судовою правотворчістю Верховного суду та Свропейського суду з прав людини та необхідністю вжиття заходів загального характеру з метою забезпечення додержання державою положень європейської Конвенції про захист прав людини та основоположних свобод, порушення яких встановлене рішеннями Європейського суду з прав людини, забезпечення усунення недоліків системного характеру, які лежать в основі виявленого Судом порушення, а також усунення підстави для надходження до Суду заяв проти України, спричинених проблемою, що вже була предметом розгляду в Суді.

\section{Список використаних джерел:}

1. Мельник М.В. Інститут митних режимів в митному праві України: дис. ... канд. юрид. наук : 12.00.07 «Адміністративне право і процес; фінансове право; інформаційне право» ; Міжрегіональна академія управління персоналом. Київ, 2016. 251 с.

2. Білак Н.I. Особливості переміщення об'єктів інтелектуальної власності через митний кордон України : автореф. дис. ... канд. юрид. наук : 12.00 .07 «Адміністративне право і процес; фінансове право; інформаційне право» ; Міжнародний гуманітарний університет. Одеса, 2019. 25 с.

3. Назарова Я.Б. Правове регулювання митних режимів тимчасового ввезення та тимчасового вивезення : автореф. дис. ... канд. юрид. наук : 12.00 .07 «Адміністративне 
право і процес; фінансове право; інформаційне право» ; Національний юридичний університет імені Ярослава Мудрого. Харків, 2016. 20 с.

4. Чуприна О.В. Правове регулювання митних режимів переробки : автореф. дис. ... канд. юрид. наук : 12.00 .07 «Адміністративне право і процес; фінансове право; інформаційне право» ; Національний юридичний університет імені Ярослава Мудрого. Харків, 2015. 20 с.

5. Чуприна О.В. Класифікація митних режимів у юридичній науці та законодавстві. Право та інновачіï. 2015. № 2 (10). С. 133-139.

6. Кодекс адміністративного судочинства України : Закон України від 6 липня 2005 року № 2747-IV (у редакції від 15 серпня 2020 року) / Верховна Рада України. URL.: https:/ / zakon.rada.gov.ua/laws/show/2747-15\#n10971.

7. Верховний суд розмежував поняття «митний контроль» та «митне оформлення» / Офіційний портал «Судова влада України». URL: https://court.gov.ua/ press/news/512072/.

8. Митний кодекс України Закон України від 13 березня 2012 року № 4495-VI (у редакції від 19 червня 2020 року) / Верховна Рада України. URL: https:/ / zakon.rada.gov.ua/ laws/show/4495-17\#Text.

9. Паркулаб А.В. Верховний суд ламає усталену практику у справах про коригування митної вартості? Протокол: юридичний інтернет-ресурс. Юридичний портал Протокол. Юридична дискусія. Статті. URL: https://protocol.ua/ua/verhovniy_sud_ lamae_ustalenu_praktiku_u_spravah_pro_koriguvannya_mitnoi_vartosti/.

10. Конституція України : Закон України від 28 червня 1996 року № 254к/96-ВР (у редакції від 01 січня 2020 року) / Верховна Рада Украйни. URL: https:/ / zakon.rada.gov.ua/ laws/show/254к/96-вр\#Text.

11. Давидчук О.В. Виконання рішень Європейського суду з прав людини / Міністерство юстиції України. URL: https:/ / minjust.gov.ua/m/str_7591.

12. Рішення Європейського суду $з$ прав людини у справі «Садоха проти України» (Заява № 77508/11) від 11 липня 2019 року (набуло статус остаточного 11 жовтня 2019 року). База даних «Законодавство України». URL: https:/ /zakon.rada.gov.ua/laws/ show/974_e50.

13. Рішення Свропейського суду з прав людини у справі «Мякотін проти України» (Заява № 29389/09) від 17 грудня 2019 року. База даних «Законодавство Украӥни». URL.: https://zakon.rada.gov.ua/laws/show/974_e79. 
УДК 342.9

DOI https:// doi.org/10.32850/LB2414-4207.2020.14.20

\title{
СТРУКТУРА АДМІНІСТРАТИВНО-ПРАВОВОГО МЕХАНІЗМУ ЗАХИСТУ СУБ'СКТИВНИХ ПУБЛІЧНИХ ПРАВ ПРИВАТНОЇ ОСОБИ
}

\author{
Чуб Антон Володимирович, \\ кандидат юридичних наук, \\ здобувач кафедри адміністративного \\ та господарського права \\ (Запорізький національний \\ університет, \\ м. Запоріжжя, Україна)
}

У науковій статті досліджено структуру адміністративно-правового механізму захисту суб'єктивних публічних прав приватної особи. Визначено, що адміністративно-правовий механізм захисту суб'єктивних публічних прав приватної особи $є$ складовою частиною адміністративно-правового механізму забезпечення прав і свобод особи. Метою дослідження є здійснення характеристики структури адміністративно-правового механізму захисту суб'єктивних публічних прав приватної особи. Обгрунтовано доцільність розуміння під адміністративно-правовим механізмом забезпечення прав і свобод приватної особи системи засобів, що є складовими елементами системи впливу на суспільні відносини та визначені чинним законодавством України нормами гарантії реалізації цих прав (захист прав та інтересів у адміністративного порядку, захист за допомогою адміністративної відповідальності, захист прав та інтересів особи у порядку адміністративного судочинства). Нормативно-правовим базисом здійснення адміністративного оскарження визначено сукупність правових норм, які регулюють суспільні відносини, що виникають із приводу реалізації фізичною чи юридичною особи права на оскарження рішень, дій і бездіяльності органів виконавчої влади шляхом подання скарги до органу виконавчої влади (посадової особи), уповноваженого здійснювати їх розгляд і вирішення. Інституційною складовою частиною адміністративно-правового механізму захисту суб'єктивних публічних прав визначено систему органів державної влади та місцевого самоврядування. Обгрунтовано, що адміністративно-правовий механізм захисту суб'єктивних публічних прав приватної особи є теоретичною конструкцією, що містить у своїй структурі нормативний базис, системно-суб'єктний склад і формальний порядок здійснення адміністративно-правових заходів у сфері превентивної охорони та захисту й відновлення порушених публічних інтересів. Проблемами забезпечення ефективності реалізації адміністративно-правового механізму суб'єктивних публічних прав є відсутність нормативно-правового регулювання здійснення адміністративних процедур, правозастосовчі прогалини регламентації здійснення владними суб'єктами дискреційних повноважень тощо.

Ключові слова: адміністративне оскарження, захист, механізм, реалізація, суб'єктивні публічні права. 


\title{
STRUCTURE OF THE ADMINISTRATIVE AND LEGAL MECHANISM OF PROTECTION OF THE SUBJECTIVE PUBLIC RIGHTS OF A PRIVATE PERSON
}

\author{
Chub Anton Volodymyrovych, \\ Candidate of Law, \\ Applicant at the Department of \\ Administrative and Commercial Law \\ (Zaporizhzhia National University, \\ Zaporizhzhia, Ukraine)
}

The scientific article examines the structure of the administrative and legal mechanism for the protection of subjective public rights of an individual. It is determined that the administrative-legal mechanism of protection of subjective public rights of an individual is a component of the administrative-legal mechanism of ensuring the rights and freedoms of an individual. The purpose of this study is to characterize the structure of the administrative and legal mechanism for the protection of subjective public rights of the individual. The expediency of understanding under the administrative-legal mechanism of ensuring the rights and freedoms of an individual is necessary to understand the system of means that are components of the system of influence on public relations and the definition of current legislation of Ukraine to ensure the implementation of these rights. administrative liability, protection of the rights and interests of the person in administrative proceedings). The normative-legal basis for the implementation of an administrative appeal is a set of legal norms governing public relations arising from the exercise of the right of an individual or legal entity to appeal against decisions, actions and omissions of executive bodies by filing a complaint to the executive body (official) to consider and resolve them. The institutional component of the administrative and legal mechanism for the protection of subjective public rights is the system of public authorities and local self-government. It is substantiated that the administrative-legal mechanism of protection of subjective public rights of an individual is a theoretical construction, which contains in its structure the normative basis, systemsubject composition and formal procedure of administrative-legal measures in the field of preventive protection and protection and restoration of violated public interests. Problems of ensuring the effectiveness of the implementation of the administrative-legal mechanism of subjective public rights are the lack of legal regulation of administrative procedures, law enforcement gaps in the regulation of the exercise of discretion by the authorities, etc.

Key words: administrative appeal, protection, mechanism, implementation, subjective public rights.

Постановка проблеми. Адміністративно-правовий механізм захисту суб' єктивних публічних прав приватної особи є складовою частиною адміністративно-правового механізму забезпечення прав і свобод особи. Під адміністративно-правовим механізмом забезпечення прав і свобод приватної особи необхідно розуміти систему засобів, що є складовими елементами системи впливу на суспільні відносини та визначені чинним законодавством України гарантії реалізації цих прав (захист прав та інтересів у адміністративного порядку, захист за допомогою адміністративної відповідальності, захист прав та інтересів особи у порядку адміністративного судочинства) [1, с. 19].

Стан наукової розробки проблеми. Варто виділити наукові розробки таких вчених, як В.Б. Авер'янов, Ю.П. Битяк, В.І. Васильєва, О.В. Гончарук, Б.М. Дронів, С.П. Погребняк, Р.В. Сивий, В.М. Селіванов, В.В. Галунько, Р.А. Калюжний, М.П. Кунцевич, Ю.О. Легеза, С.В. Савченко, О.М. Вінник, Є.В. Курінний, В.К. Колпаков, Т.О. Коломоєць, А.Я. Курбатов, С.Т. Гончарук та ін. Однак у дослідженнях представ- 
ників адміністративної науки відсутнє комплексне дослідження особливостей адміністративно-правового захисту суб' єктивних публічних прав приватної особи.

Метою дослідження є здійснення характеристики структури адміністративно-правового механізму захисту суб' єктивних публічних прав приватної особи.

Виклад основного матеріалу. Особливостями адміністративно-правового механізму захисту прав, свобод та інтересів приватної особи є його чотирирівневість, що містить у собі нормативний, інституційний, адміністративно-процедурний (управлінський) та адміністративно-правозастосовний складники; саме поєднання таких складових частин є гарантією забезпечення невладним суб'єктам адміністративного права можливостей реалізації ними своїх прав, свобод та інтересів [2, с. 33].

I.О. Грибок визначає, що сутність оскарження рішень органів виконавчої влади в адміністративному порядку є формою позасудового захисту прав і свобод фізичних і юридичних осіб, що порушені рішеннями, діями та бездіяльністю органів виконавчої влади [3, с. 56-60]. Інститут адміністративно-правового захисту прав приватної особи у порядку адміністративного оскарження, за обгрунтуванням I.О. Грибка, складається із: а) норм, що законодавчо встановлюють реалізації прави особи на оскарження рішень, дій і бездіяльності органів виконавчої влади; б) норм, зміст яких встановлюють форму і порядок реалізації приватною особи можливості здійснення адміністративного оскарження; в) норм, що визначають принципи адміністративного оскарження; г) норм, які регламентують порядок здійснення адміністративного провадження за скаргою, а також визначають порядок оскарження рішення, прийнятого за результатом розгляду скарги; д) норм, що визначають суб'єктів і порядок здійснення окремих видів контролю за дотриманням законодавства, яке регламентує адміністративне оскарження; е) норм, що встановлюють підстави та види юридичної відповідальності учасників адміністративного провадження за скаргами [3, с. 56-60].

Визначення такого розуміння нормативно-правового базису здійснення адміністративного оскарження дозволяє його визначити як правовий інститут, що є сукупністю правових норм, які регулюють суспільні відносини, котрі виникають із приводу реалізації фізичною чи юридичною особи права на оскарження рішень, дій і бездіяльності органів виконавчої влади шляхом подання скарги до органу виконавчої влади (посадової особи), уповноваженого здійснювати їх розгляд і вирішення [3, с. 55-56]. I.О. Грибок обгрунтовує авторський висновок, що наявність механізму адміністративного оскарження дозволяє забезпечити вирішення адміністративно-правового конфлікту (спору) між фізичною чи юридичною особою й органом виконавчої влади. Тому характер адміністративно-правових спорів, їхні особливості визначають специфіку інституту адміністративного оскарження. Сутність адміністративно-правового спору визначається його характерними ознаками: 1) підставою виникнення адміністративно-правового спору є публічно-управлінські відносини; 2) суб'єктний склад відносин адміністративно-правового спору визначається наявністю органу державної влади чи місцевого самоврядування; 3) предметом адміністративно-правових спорів $€$ рішення, дії чи бездіяльність одного із суб'єктів (переважно владних суб'єктів) адміністративно-правових відносин; вони пов'язані з уявленням однієї зі сторін адміністративно-правових відносин, що ії права чи законні інтереси порушуються якимось чином; 4) врегулювання адміністративно-правового спору вимагає визначення чіткої регламентованої процедури, дотримання певної процесуальної форми реалізації, дотримання принципу стадійності врегулювання (подання скарги на рішення, дію чи бездіяльність владних суб'єктів тощо) [3, с. 55-56].

Отже, реалізація захисту суб'єктивних публічних прав приватної особи вимагає наявності нормативної складової частини, що відображається у системі адміністратив- 
но-правових норм, застосування яких забезпечує участь невладних суб'єктів адміністративного права у відносинах владно-управлінського характеру. Іншими словами, цей рівень є джерельно-правовою базою здійснення адміністративно-правового захисту суб'єктивних публічних прав приватної особи.

Найвищий рівень нормативно-правового регулювання адміністративно-правового механізму захисту суб'єктивних публічних прав приватної особи складає сукупність законодавчих актів.

Передусім право на адміністративне оскарження закріплюється положеннями конституційних норм. Відповідно до ч. 5 ст. 55 Конституції України визначено, що «кожен має право будь-якими не забороненими законом засобами захищати свої права і свободи від порушень і протиправних посягань» [4]. Як підкреслює О.Ф. Андрійко, конституційне закріплення права на оскарження визначає його як суб'єктивне право, що створює певні юридичні гарантії його реалізації [5, с. 16; 6, с. 27-35]. Крім того, конституційне закріплення права на оскарження визначає гарантування його реалізації на підставі порушення норм прямої дії.

Отже, до характерних ознак інституту адміністративного оскарження належить те, що його реалізація дозволяє визначити форму та зміст процедури позасудового врегулювання вирішення адміністративно-правового спору (конфлікту) між приватною особою та суб'єктом владних повноважень.

Таким чином, передумовою для реалізації права на адміністративне оскарження $\epsilon$ наявність адміністративно-правового (публічно-правового) спору. I.О. Грибок взагалі відзначає, що адміністративний порядок оскарження рішень, дій чи бездіяльності пріоритетною метою його реалізації має саме врегулювання публічно-правового спору [3, с. 20-25]. До моменту внесення змін до Кодексу адміністративного судочинства України (далі - КАС України) наявною була ситуація нормативної невизначеності категорії «публічно-правового спору» чи синонімічної до неї поняття «адміністративно-правовий спір» [7].

Відповідно до чинної редакції КАС України обгрунтовано уточнене розуміння публічно-правового спору, сутнісною ознакою якого визначено не тільки наявність спеціального суб'єкта - суб'єкт, котрий «здійснює публічно-владні управлінські функції», неналежним чином виконує покладені на нього повноваження, в т. ч. делеговані, а й додатково підкреслюється, як зазначає А.Л. Правдюк, що до публічно-правових спорів належать конфлікти, які виникають у сфері надання адміністративних послуг [8].

Відповідно до п. 2 ч. 1 ст. 4 КАС України встановлюється, що під публічно-правовим спором необхідно розуміти спір, у якому:

- хоча б одна сторона здійснює публічно-владні управлінські функції, в т. ч. на виконання делегованих повноважень, і спір виник у зв'язку із виконанням або невиконанням такою стороною зазначених функцій;

- хоча б одна сторона надає адміністративні послуги на підставі законодавства, яке уповноважує або зобов' язує надавати такі послуги виключно суб' єкта владних повноважень, і спір виник у зв' язку із наданням або ненаданням такою стороною зазначених послуг;

- хоча б одна сторона $є$ суб'єктом виборчого процесу або процесу референдуму і спір виник у зв' язку із порушенням ії прав у такому процесі з боку суб'єкта владних повноважень або іншої особи [9].

Варто підкреслити, що реформи системи адміністративного законодавства виявили доцільність відмови від суб'єктних характеристик публічно-правових спорів як пріоритетної категорії у встановленні сутності того чи іншого правового конфлікту і необ- 
хідність визначення його сутності через розуміння його предмету, що підтримується і представниками юридичної науки (Л.Б. Сало, І.Я. Сенюта, Н.С. Хлібороб, А.М. Школик, Н.В. Янюк та ін.) [10, с. 60-63].

Відмова від пріоритетності суб'єктного критерію у визначенні сутності правового конфлікту вимагає звернення уваги на його предметну характеристику. Для адміністративно-правових спорів визначальною характеристикою є наявність такого критерію, як публічний інтерес. Однозначності підходів до розуміння категорії «публічного інтересу» досі немає. Зокрема, авторським колективом навчального посібника «Способи вирішення публічно-правових спорів з органами влади» [11, с. 78-85] визначено, що змістом публічного інтересу є «пропорційне врахування інтересів фізичних і юридичних осіб, територіальної громади, держави та суспільства». Тож в основу розмежування приватноправового й публічно-правового спорів покладається вирішення питання, чи внаслідок прийнятого управлінського рішення особою досягається отримання бажаного для неї матеріального або нематеріального блага, що є характерним для першої групи правових конфліктів, тоді як в основу публічно-правових спорів покладається наявність управлінсько-владного впливу на громадянина чи іншого суб'єкта [11, с. 86-88].

Зокрема, є практика зарахування до категорії приватноправових спорів розгляду спорів щодо правомірності рішень суб'єктів владних повноважень із питань передання земельної ділянки до права власності фізичної особи (у такому разі підлягає розгляду в порядку цивільного судочинства) або юридичній особі (відповідно, є юрисдикцією господарських судів). Зокрема, прикладом, що свідчить про обгрунтованість такого висновку, є положення Рішення Верховного Суду України від 29 березня 2017 р. у справі № 21-3412а16 [12].

Цікавим у цьому аспекті є міркування, наведені у наукових працях Ю.О. Легези [13, с. 208-212], якою обстоюється підхід доцільності віднесення спорів у сфері захисту права на безпечне довкілля до категорії адміністративних спорів через те, що їх предметом $є$ недотримання встановлених стандартів використання й охорони природних ресурсів, які відповідно до Конституції України є стратегічним економічним і правовим базисом реалізації права виключної власності Українського народу на землю, іiі надра, атмосферне повітря, водні та інші природні ресурси, що знаходяться в межах території України, природні ресурси ії континентального шельфу, виключної (морської) економічної зони (ст. 13) [4].

Відмова від суб'єктного підходу до визначення категорії «публічно-правового спору» унеможливлює реалізацію класифікації спорів на публічно-правові та приватно-правові спори за ознакою наявності суб'єкта владних повноважень. Вирішення такої правової колізії окремою групою вчених пов'язується з необхідністю запровадження категорії «публічний інтерес» [14, с. 162-167; 11, с. 45-50]. Л.О. Золотухіна визначає публічний інтерес як «розуміння публічного інтересу як сукупності визнаних державою історично усталених і ситуативних об'єктивно існуючих потреб, прагнень, цілей громадських об'єднань, окремих соціальних груп, територіальних громад, суспільства, нації та інших учасників правовідносин, механізм реалізації й захисту якої визначається відповідно до чинного законодавства України» [15, с. 94-99].

Натомість нормативне визначення категорії «публічний інтерес» досі немає, що не означає відсутність випадків його застосування, в т. ч. у процесі врегулювання адміністративно-правових спорів. Зокрема, відповідно до постанови Великої Палати Верховного Суду України від 13 лютого 2019 р. у справі № 810/2763/17 визначено, що публічним інтересом є «важливі для значної кількості фізичних і юридичних осіб потреби, які відповідно до законодавчо встановленої компетенції забезпечуються 
суб'єктами публічної адміністрації. Тобто публічний інтерес є певною сукупністю приватних інтересів» [16].

Таким чином, реалізація права на оскарження виникає у приватної особи у разі порушення ії суб'єктивних публічних чи суб'єктивних приватних прав та інтересів. Підставою для оскарження $є$ виникнення адміністративно-правового спору, сутнісною характеристикою якого є наявність не лише спеціального суб'єктного складу і його предмету - порушення публічного інтересу у розумінні сукупності визнаних державою історично усталених і ситуативних об'єктивно існуючих потреб, прагнень, цілей громадських об'єднань, окремих соціальних груп, територіальних громад, суспільства, нації та інших учасників правовідносин, механізм реалізації й захисту якої визначається відповідно до чинного законодавства України.

Безпосередньо реалізація права на адміністративне оскарження рішень, дій чи бездіяльності суб'єктів владних повноважень, що впливають на ефективність здійснення суб'єктивних публічних прав приватної особи, здійснюється, зокрема, відповідно до Закону України «Про звернення громадян» [17]. Однак з урахуванням віднесення до категорії «приватної особи» не лише фізичних, але і юридичних осіб реалізація останніми права на адміністративне оскарження для останніх $є$ неможливою із застосуванням положень Закону України «Про звернення громадян». Подолання такої прогалини у забезпеченні реалізащії права на адміністративне оскарження приватними особами, як фізичними, так і юридичними, стане можливим із прийняттям Закону України «Про адміністративну процедуру».

До складових частин системи нормативно-правового регулювання реалізації права на адміністративне оскарження належить і практика Свропейського суду з прав людини, що відповідає положенням Угоди про асоціацію між Україною, з однієї сторони, та Європейським Союзом, Свропейським співтовариством $з$ атомної енергії і їхніми державами-членами [18] та Закону України від 18 березня 2004 р. «Про Загальнодержавну програму адаптації законодавства України до законодавства Свропейського Союзу» [19].

Застосування результатів практики реалізації європейського законодавства, на думку P.I. Раімова [20], дозволяє вирішити конкретну задачу із «правильного застосування законодавства, що становить публічний інтерес» (рішення ЄСПЛ у справі «Трегубенко проти України» від 2 листопада 2004 р.) [21].

Інституиіийню складовою частиною адміністративно-правового механізму захисту суб'єктивних публічних прав є система органів державної влади та місцевого самоврядування. Саме від ефективності діяльності органів державної влади та місцевого самоврядування залежить досягнення належного рівня забезпечення та сприяння в реалізації фізичними та юридичними особами суб'єктивних публічних прав у адміністративно-правових відносинах; захист публічних інтересів, які в найбільш загальному розумінні можна визначити як сукупність приватних інтересів, $є$ окремою складовою частиною такого завдання.

Сучасний стан діяльності органів державної влади, органів місцевого самоврядування, їхніх посадових і службових осіб характеризується недостатньо ефективним виконанням владно-управлінських функцій у різних сферах суспільного життя. Показники, які визначають ступінь їх реалізації, свідчать про необхідність посилення ролі правових засобів і форм визначення компетенції суб' єктів владних повноважень, що гарантуватиме законність державного управління. Здійснення таких заходів неможливе без усвідомлення важливості продовження проведення в Україні адміністративної реформи, серед головних напрямів якої залишається забезпечення принципу верховенства права у державі. Тільки за правильного розподілу компетенційних сфер і належного правового регулювання владної діяльності можливий подальший 
розвиток діалогу між суспільством і державою [22, с. 32], збалансування приватних, суспільних і державних інтересів.

До елементів адміністративно-правового механізму захисту суб'єктивних публічних прав приватної особи належить і адміністративно-проиедурний структурний елемент, що розуміється як сукупність адміністративних процедур, за допомогою яких відбувається реалізація прав, свобод та інтересів невладних суб'єктів адміністративного права. Пріоритетною метою застосування процедури адміністративного оскарження, як відзначає В.Б. Авер' янов, є відновлення порушених інтересів, підвищення ефективності управлінської діяльності, сприяння чіткому виконанню функцій і повноважень органами та посадовими особами публічної влади [23, с. 238].

Л.О. Золотухіна відзначає необхідність виділення в адміністративно-правовому механізмі захисту публічного інтересу адміністративно-судочинного й адміністративно-деліктного елементів [24, с. 312-315], останній розуміється як реалізація правових норм, що передбачають адміністративну відповідальність через нормативно визначену діяльність уповноважених органів публічної адміністрації.

Висновок. Таким чином, адміністративно-правовий механізм захисту суб'єктивних публічних прав приватної особи є теоретичною конструкцією, яка містить у своїи структурі нормативний базис, системно-суб'єктний склад і формальний порядок здійснення адміністративно-правових заходів у сфері превентивної охорони та захисту й відновлення порушених публічних інтересів. Проблемами забезпечення ефективності реалізації адміністративно-правового механізму суб'єктивних публічних прав є відсутність нормативно-правового регулювання здійснення адміністративних процедур, правозастосовні прогалини регламентації здійснення владними суб'єктами дискреційних повноважень тощо.

\section{Список використаних джерел:}

1. Ієрусалімова I.О. Механізм адміністративно-правового забезпечення прав і свобод людини та громадянина : дис. ... канд. юрид. наук : 12.00.07. Київ, 2006. 205 с.

2. Ліпкан В.А. Національна безпека України : навчальний посібник. 2009. Київ : KHT. 576 c.

3. Грибок I.О. Оскарження рішень органів виконавчої влади в адміністративному порядку : дис. ... канд. юрид. наук : 12.00 .07 ; НАН України, Ін-т держави і права ім. В.М. Корецького. Київ, 2006. 220 с.

4. Конституція України : Закон України від 28 червня 1996 р. Відомості Верховної Ради України. № 30. Ст. 141.

5. Андрійко О.Ф. Державний контроль: теорія і практика: Наук. доповідь. Київ : Інститут держави і права ім. В.М. Корецького, 1999. С. 9-12.

6. Андрійко О.Ф. Державний контроль на етапі реформування. Наукові засади вирішення організаційно-правових проблем адміністративної реформи в Украйні : Наукова доповідь / за заг. ред. В.Б. Авер' янова. Київ : Інститут держави і права ім. В.М. Корецького, 1999. С. 27-35.

7. Про внесення змін до Господарського процесуального кодексу України, Цивільного процесуального кодексу України, КАС та інших законодавчих актів : Закон України від 03 жовтня 2017 р. Відомості Верховної Ради. 2017. № 48. Ст. 436.

8. Правдюк А.Л. До питання систематизації норм адміністративної відповідальності за порушення земельного законодавства. Науковий вісник Національного університету біоресурсів і природокористування Украйни. 2014. Вип. 197. Ч. 2. С. 214-219.

9. Кодекс адміністративного судочинства України від 6 липня 2005 р. № 2747-IV. Відомості Верховної Ради Украӥни (ВВР). 2005. № 35-36, № 37. Ст. 446. 
10. Шепель М.А. Способи вирішення адміністративних спорів у сфері захисту права людини на безпечне довкілля. Прикарпатський юридичний вісник. 2018. № 2. Т. 2. С. 60-63.

11. Способи вирішення публічно-правових спорів з органами влади : практичний посібник / Л.Б. Сало, І.Я. Сенюта, Н.С. Хлібороб, А.М. Школик. Дрогобич : Коло, 2009. 112 c.

12. Рішення суб'єкта владних повноважень про передачу у власність земельної ділянки оскаржується в порядку цивільного судочинства і є спором про право (Рішення Верховного Суду України від 29 березня 2017 р. у справі № 21-3412a16). URL: http://protokol.com.ua/ua/vsu_rishennya_sub_ekta_vladnih_povnovagen_pro_ peredachu_u_vlasnist_zemelnoi_dilyanki_oskarguetsya_u_poryadku_tsivilnogo_ sudochinstva_i_e_sporom_pro_pravo.

13. Легеза Ю.О. Адміністративно-правові засади публічного управління у сфері використання природних ресурсів : дис. ... докт. юрид. наук : 12.00.07. Запоріжжя, 2018. 512 c.

14. Шепель М.А. Позивач у адміністративних спорах у сфері захисту права людини на безпечне довкілля: проблеми представництва інтересів. Наукові праці Національного університету «Одеська юридична академія» 2019. № 25. С. 72-80.

15. Золотухіна Л.О. Зміст публічного інтересу як адміністративно-правової категоpiï. Прикарпатський юридичний вісник. 2017. № 1. Т. 2. С. 94-99.

16. Справа № 810/2763/17: постанова Великої Палати Верховного Суду України від 13 лютого 2019 p. URL: https:/ / verdictum.ligazakon.net/document/79883398.

17. Про звернення громадян: Закон України від 2 жовтня 1996 р. № 393/96-ВР. Відомості Верховної Ради України. 1996. № 47. Ст. 256. URL: https:/ /zakon2.rada.gov.ua/ laws/show/393/96-вр.

18. Угода про асоціацію між Україною, з однієї сторони, та Свропейським Союзом, Свропейським співтовариством 3 атомної енергії і їхніми державами-членами, 3 іншої сторони : Закон України від 16 вересня 2014 р. № 1678-VII. URL: https://zakon.rada.gov.ua/laws/show/984_011\#Text.

19. Про Загальнодержавну програму адаптації законодавства України до законодавства Європейського Союзу : Закон України від 18 березня 2004 p. № 1629-IV. Вiдомості Верховної Ради Украӥни. 2004. № 29. Ст. 367.

20. Раімов P.I. Практика Свропейського суду 3 прав людини щодо визначення меж поняття «Публічний інтерес». Науковий вісник Ужгородського національного університету. 2017. Серія: Право. Вип. 47. Т. 2. С. 157-162. URL: http:/ / www.visnyk-juris.uzhnu.uz.ua/file/No.47/part_2/38.pdf.

21. Справа «Трегубенко проти України» : рішення ЄСПЛ від 2 листопада 2004 р. URL: https://zakon.rada.gov.ua/laws/show/980_355\#Text.

22. Муза О.В. Адміністративно-правовий механізм захисту прав, свобод та інтересів фізичних і юридичних осіб в Україні. Наукові записки Інституту законодавства Верховної Ради України. 2014. № 6. С. 32-36. C. 33. URL: https://instzak.com/index.php/journal/ article/download/486/536/.

23. Виконавча влада і адміністративне право / за ред. В.Б. Авер' янова; НАН України, Інститут держави і права ім. В.М. Корецького. Київ : Ін Юре, 2002. 668 с.

24. Золотухіна Л.О. Публічний інтерес як адміністративно-правова категорія : дис. ... докт. юрид. наук : 12.00.07. Запоріжжя, 2019. 486 с. 


\title{
ПРОБЛЕМИ КРИМІНАЛЬНОГО ПРАВА ТА КРИМІНОЛОГІї
}

УДК 343.85

DOI https:/ / doi.org/10.32850/LB2414-4207.2020.14.21

\section{АКТУАЛЬНІ ПИТАННЯ ЗАПОБІГАННЯ ДОМАШНІЙ ЗЛОЧИННОСТІ: ДОСВІД ЗАРУБІЖНИХ КРАЇН}

\author{
Барбарош Лариса Миколаївна, \\ аспірант кафедри кримінального, \\ кримінально-виконавчого права \\ та кримінології \\ (Академія Державної \\ пенітенціарної служби, \\ м. Чернігів, Україна)
}

У статті розкрито актуальні питання запобігання домашній злочинності з урахуванням досвіду зарубіжних країн. Науково обгрунтовано, що використання в Україні зарубіжного досвіду запобігання домашній злочинності дозволить мінімізувати іiі рівень відповідно до сучасних можливостей правоохоронних органів, дотримання законності, охорони конституційних прав і свобод громадян України.

Історія запобігання домашній злочинності показує, що це не тільки вітчизняна, a і міжнародна проблема. Початком запобігання домашній злочинності в зарубіжних країнах варто вважати результати активності жіночого руху на міжнародному рівні, що відобразилися у хронології конференцій, у текстах декларацій і конвенцій Організації Об'єднаних Націй, резолюцій регіональних міжнародних організацій, інших міжнародних документів останніх десятирічь, серед яких насамперед слід виділити Конвенцію ООН про ліквідацію усіх форм дискримінації стосовно жінок.

Поступове визнання феномену домашньої злочинності збігалося 3 де-юре визнанням принципу рівності жінок і чоловіків та всебічним його закріпленням у численних міжнародних правових актах. У них, зокрема, передбачалися: рівність прав жінок та чоловіків; визнання права кожного на життя, свободу та тілесну недоторканність; заборона тортур або жорстокого, нелюдського чи такого, що принижує його гідність, поводження і покарання.

Проаналізовано досвід запобігання домашній злочинності в Німеччині, Великій Британії, Швеції, Норвегії, Швейцарії, Ізраїлі, Греції, Італії, Франції.

Зроблено висновок, що вивчення зарубіжного досвіду та впровадження найкращих зарубіжних практик у вітчизняне правове поле допоможе Україні вирішити низку проблем, що виникають сьогодні в нашій країні у сфері запобігання домашній злочинності. Зокрема, йдеться про створення дієвого правового механізму захисту прав жертв домашньої злочинності в Україні, створення центрів допомоги жертвам домашньої злочинності у кожній територіальній громаді тощо.

Ключові слова: запобігання, кривдник, жертва, злочинність, зарубіжні країни, домашня сфера, правоохоронні органи. 


\title{
URGENT ISSUES OF DOMESTIC CRIMINALITY PREVENTION: EXPERIENCE OF FOREIGN COUNTRIES
}

\author{
Barbarosh Larysa Mykolaivna, \\ Postgraduate Student at the Department \\ of Criminal, Criminal and Executive Law \\ and Criminology \\ (Academy of the State Penitentiary \\ Service, Chernihiv, Ukraine)
}

The article reveals urgent issues of domestic criminality prevention taking into account the experience of foreign countries. It is scientifically substantiated that the use of foreign experience in preventing domestic criminality in Ukraine will minimize its level in accordance with the modern capabilities of law enforcement agencies, compliance with the law, protection of constitutional rights and freedoms of citizens of Ukraine.

The history of domestic criminality prevention shows that this is not only a national but also an international problem. The beginning of the prevention of domestic criminality in foreign countries should be considered the results of women's movement at the international level, reflected in the chronology of conferences, texts of United Nations declarations and conventions, resolutions of regional international organizations and other international documents of recent decades. The UN Convention on the Elimination of All Forms of Discrimination against Women should be highlighted.

The gradual recognition of the phenomenon of domestic criminality coincided with the de jure recognition of the principle of equality between women and men and its comprehensive enshrinement in numerous international legal instruments. They provided, in particular, for the equal rights of women and men, recognition of the right of everyone to life, liberty and security of person, the prohibition of torture or cruel, inhuman or degrading treatment or punishment.

The experience of domestic criminality prevention in Germany, Great Britain, Sweden, Norway, Switzerland, Israel, Greece, Italy, France is analyzed.

It is concluded that the study of foreign experience and the introduction of best foreign practices in the national legal field will help Ukraine to solve a number of problems that arise today in our country in the field of domestic criminality prevention. In particular, it is a question of creation of the effective legal mechanism of protection of the rights of victims of domestic criminality in Ukraine, creation of the centers of the help to victims of domestic criminality in each territorial community, etc.

Key words: prevention, offender, victim, criminality, foreign countries, domestic sphere, law enforcement agencies.

Постановка проблеми. Україна, як демократична і правова держава, повинна брати все найкраще з позитивних надбань інших країн у законотворчій галузі. Осмислення зарубіжного досвіду щодо вирішення проблем запобігання домашній злочинності дасть змогу прискорити успішне вирішення цієї проблеми спільними зусиллями законодавчих, правоохоронних органів та громадськості.

На необхідності запозичення світового досвіду наголошують сучасні українські дослідники. Варто підтримати позицію О.В. Ковальової про те, що вивчення досвіду інших країн з вирішення проблеми запобігання домашній злочинності дозволить українським науковцям і практикам використовувати все позитивне із того, що вже розроблено, впроваджено та апробовано в цих країнах, а також утриматись від використання методів та підходів, які себе не справдили [1, с. 81-82]. 
Принагідно зазначимо, що тема дослідження «Прокуратура як суб'єкт запобігання домашній злочинності в Україна» обрана нами невипадково: вона кореспондується 3 напрацюваннями учених наукової школи «Інтелект» під керівництвом відомого в Україні вченого професора І.Г. Богатирьова і $є$ логічним продовженням iï дослідження в Україні [2, с. 115].

Історія запобігання домашній злочинності показує, що це не тільки вітчизняна, а і міжнародна проблема. Початком запобігання домашній злочинності в зарубіжних країнах варто вважати результати активності жіночого руху на міжнародному рівні, що відобразилися у хронології конференцій, у текстах декларацій і конвенцій Організації Об'єднаних Націй (ООН), резолюцій регіональних міжнародних організацій, інших міжнародних документів останніх десятирічь, серед яких насамперед слід виділити Конвенцію ООН про ліквідацію усіх форм дискримінації стосовно жінок [3].

Поступове визнання феномену домашньої злочинності збігалося з де-юре визнанням принципу рівності жінок і чоловіків та всебічним його закріпленням у численних міжнародних правових актах. У них, зокрема, передбачалися: рівність прав жінок та чоловіків; визнання права кожного на життя, свободу та тілесну недоторканність; заборона тортур або жорстокого, нелюдського чи такого, що принижує його гідність, поводження і покарання.

Аналіз останніх досліджень і публікацій. Питання запобігання домашній злочинності висвітлювалися в науково-теоретичних дослідженнях таких вітчизняних учених, як А.Б. Благоя, О.І. Бєлова, І.Г. Богатирьов, О.І. Богатирьова, О.В. Бойко, Б.М. Головкін, О.М. Джужа, О.І. Зазимко, О.В. Ковальова, О.Д. Коломоєць, Л.В. Крижна, М.Г. Кузнєцова, Н.В. Лесько, С.В. Романцевої, М.Ю. Самченко. Також цій проблемі присвятили свої роботи такі зарубіжні вчені, як А.А. Ахматов, Г.М. Іляшенко, Д.О. Корецький, Г.М. Міньковський, В.П. Мелешко, О.В. Старков, Д.О. Шестаков та інші.

Постановка завдання. Метою статті $\epsilon$ наукове обгрунтування використання в Україні зарубіжного досвіду запобігання домашній злочинності для мінімізації ії рівня відповідно до сучасних можливостей правоохоронних органів, дотримання законності, охорони конституційних прав і свобод громадян України.

Виклад основного матеріалу дослідження. Варто зазначити, що до середини XX ст. більшість із різновидів домашньої злочинності були фактично узаконені, а жінки й діти тривалий час взагалі вважалися безправними. Лише у 60-70-ті pp. XX ст. домашня злочинність отримала негативну оцінку з боку суспільства. Це було пов'язано насамперед з визнанням рівноправ'я чоловіків і жінок.

Важливу роль при цьому відіграло прийняття таких міжнародно-правових актів: Загальна декларація прав людини; Конвенція про політичні права жінок; Декларація прав дитини; Міжнародний пакт про громадянські і політичні права; Міжнародний пакт про економічні, соціальні і культурні права; Декларація про ліквідацію усіх форм дискримінації стосовно жінок; Декларація про викорінювання насильства стосовно жінок; Конвенція про згоду на вступ до шлюбу, мінімальний шлюбний вік та реєстрацію шлюбу; Конвенція про рівну винагороду чоловіків і жінок за рівноцінну працю; Конвенція про охорону материнства; Конвенція про рівне поводження та рівні можливості для працюючих чоловіків і жінок: працюючі із сімейними обов' язками; Конвенція про дискримінацію у сфері праці та занять тощо.

Важливість звернення до міжнародно-правових актів у сфері запобігання домашній злочинності викликана тим, що відповідно до ч. 1 ст. 9 Конституції України чинні міжнародні договори, згода на обов' язковість яких надана Верховною Радою України, $є$ частиною національного законодавства України [4]. У низці міжнародно-правових 
документів, прийнятих, зокрема, на Генеральній Асамблеї ООН, запобігання домашній злочинність розглядається у контексті боротьби за права і свободи людини.

Натепер загальновизнано, що особа, яка вчиняє кримінальне правопорушення у сфері домашньої злочинності (кривдник), порушує низку прав людини: право кожної людини на рівний захист перед законом і відсутність дискримінації за ознакою статі; право не піддаватися жорстокому поводженню; право на життя і фізичну недоторканність; право на найвищі стандарти фізичного і психічного здоров' я.

Зарубіжні країни накопичили багатий досвід 3 цієї проблеми, оскільки вона $\epsilon$ актуальною не тільки для нашої країни. У рішеннях IV Всесвітньої конференції по положенню жінок (Пекін, 4-15 вересня 1995 р.), інших міжнародних правових документах підкреслюється, що необхідна розробка комплексного та багатодисциплінарного підходу до вирішення важливого завдання з викорінення домашньої злочинності в суспільстві та державі; ідеєю рівності, партнерства між чоловіками і жінками та повагою людської гідності повинні бути проникнуті усі етапи процесу соціалізації людини [5, с. 81]. Зазначений документ вимагає підвищення рівня знань і розуміння причин, наслідків та механізмів домашньої злочинності.

У Свропі завдяки активним діям міжнародних правозахисних організацій останніми роками істотно розширилися уявлення про дотримання прав людини, зокрема, змінилося розуміння відповідальності держави за вчинення особою (кривдником) кримінального правопорушення у сфері домашньої злочинності.

Під тиском громадськості у більшості країн Європи почалося державне субсидіювання кризисних центрів для жертв домашньої злочинності. Оскільки попередні закони не враховували специфіку і складність цього виду злочинності, то пропонувалися різні додаткові заходи та поправки до цивільного, адміністративного, кримінального законодавств, а більшість держав стали розробляти спеціальні закони, мета яких полягала у створенні правової бази для реалізації комплексного підходу до вирішення проблем домашньої злочинності. Тепер такі закони діють у більшості держав Європейського Союзу.

Не є виключенням у цьому відношенні і Федеративна Республіка Німеччина, де проблема домашньої злочинності актуальна як ніколи [6, с. 422]. Тому серед найважливіших своїх завдань федеральний уряд називає ефективну боротьбу з насильством проти жінок, допомогу жертвам і послідовне покарання злочинців. Основна профілактична робота в цьому напрямі покладена на Федеральне міністерство у справах сім'ї, людей похилого віку, жінок і молоді Німеччини (Bundesministerium für Familie, Senioren, Frauen und Jugend).

До найбільш розповсюджених заходів поліцейського впливу на домашню злочинність належать: вилучення з квартири (будинку) особи, від якої виходить небезпека (Wohnungsverweisung); заборона особі, від якої виходить небезпека входити до квартири (будинку) (Rückkehrverbot); вилучення з певного місця особи, від якої виходить небезпека (Platzverweis); заборона перебування (появи) у визначеному місці особі, від якої виходить небезпека (Aufenthaltsverbot); заборона вступу в контакт (словесний контакт на вулиці, по телефону, по електронній пошті тощо) особі, від якої виходить небезпека (Kontaktverbot); в особливо тяжких випадках особа, від якої виходить небезпека, береться під варту (Ingewahrsamnahme).

Серед заходів запобігання домашній злочинності з боку держави у Німеччині є турбота про майбутні покоління. Німецькі вчені стверджують, що якщо діти бачили, як ïx батьки зазнавали відкритого насильства одне від одного, їх психіка важко страждає. Здебільшого вони сприймають насильство як основу сімейних взаємин, зазнають у майбутньому експлуатації та насильства з боку батьків [7, с. 250]. 
Проблема домашньої злочинності актуальна і для Великої Британії. Найпоширенішою формою цього виду злочинності є домашнє насильство. Згідно із законом від 2004 р. домашнім насильством є будь-який випадок загрози, насильства та жорстокого поводження (психологічного, фізичного, сексуального, фінансового чи емоційного) між дорослими, які є або були співмешканцями або щодо членів сім'ї, незалежно від статі, сексуальної орієнтації [8, с. 10]. У березні 2013 р. це визначення було розширено шляхом розширення кола суб'єктів, які підлягають захистові за законом та охоплення складом зазначеного злочину примусового контролю у сім'ï [9].

Досвід англосаксонських країн із запобігання домашній злочинності показує, що ця проблема постійно перебуває під контролем держави, а тому саме держава забезпечує належне фінансування для спеціалістів місцевих служб підтримки і національних телефонів довіри, які відповідають на всі види домашньої злочинності і надають всіляку допомогу і підтримку жертвам.

У Великій Британії, зокрема, для запобігання сексуального насильства у великих містах створено 87 незалежних консультативних центрів, завдання яких - не тільки захистити жінку від сексуального насильства, а і надати їй допомогу у покаранні кривдника за примусовий шлюб. Фінансування консультативних центрів забезпечується державою. Такі центри проводять прикладні дослідження причин і умов домашнього насильства та пропонують державі відповідні заходи його запобігання.

Важливим елементом загальнодержавної програми запобігання домашній злочинності у Великій Британії визнається робота поліції. Актуальну практику взаємодії поліції з громадою у подоланні проблем домашньої злочинності запроваджує так званий британський «Закон Клер». Так, людина може звернутися в поліцію, щоб перевірити, чи має новий або існуючий партнер «насильницьке минуле». Поліція зобов' язана провести за такими запитами спеціальну перевірку та поінформувати заявника [9]. На жаль, за нашим дослідженням в Україні відсутня практика звернення громадян, які вступають в шлюбні відносини, до поліції щодо спеціальної перевірки майбутнього партнера на предмет схильності його до різних проявів домашньої злочинності. Хоча такий досвід британської поліції варто впровадити в роботу і вітчизняної поліції.

Завдяки феміністичному руху у 1970-х роках у Швеції було створено широкий соціальний консенсус щодо принципів гендерної рівності та підготовлено основу для поточної офіційної державної політики, яка спрямована на забезпечення рівних можливостей жінок і чоловіків у формуванні суспільства та власного життя. Урядова політика визначає чотири конкретні цілі: рівний розподіл влади та впливу на процес прийняття рішень; економічна рівність та рівний доступ до освіти; рівноправний розподіл неоплачуваних послуг та домашньої роботи; припинення чоловічого насильства щодо жінок [10].

Так, першим серйозним кроком на рівні законодавства стало запровадження обмежувального припису, який був уведений відповідним Законом у 1988 р. Метою Закону було запобігання злочинам, спрямованим проти осіб, які піддаються переслідуванню та домаганню, а також створення для них почуття безпеки. Закон був розроблений гендерно-нейтральним, але огляду на його обгрунтування зрозуміло, що Закон, призначався для застосування в ситуаціях, коли жінка зазнала насильства чи загрози, перебуваючи у відносинах, або де людина переслідує і домагається жінку в інтимних відносинах, що вже закінчились [11].

У 1998 р. до КК Швеції був введений новий злочин - грубе порушення недоторканості жінки. До речі, було також введено нове визначення: «Сексуальне переслідування», яке означає таку небажану поведінку на основі статевої чи небажаної поведінки сексуального характеру, що порушує цілісність працівника на роботі [12]. 
Варто зауважити, що і сьогодні законодавство Швеції про запобігання та протидію гендерному і домашньому насильству продовжує розвиватися. Так, 1 липня 2018 р. набув чинності новий Закон, що стосується сексуальної згоди, прийнятий на виконання положення ст. 36 Стамбульської конвенції. У новому законодавчому акті визначено, якщо секс не є добровільним - він є нелегальним і знаходиться поза межами Закону. Наразі щоб притягнути кривдника до відповідальності, необов'язково доводити те, що під час сексуальних стосунків застосовувалося насильство або погрози.

У Норвегії особлива увага приділяється захисту та реабілітації жертви домашньої злочинності. Відповідно до чинного законодавства на відповідний орган муніципальної влади покладається обов'язок надати жертві домашнього насильства (незалежно від статі) безкоштовний тимчасовий притулок (або інше місце проживання), забезпечити доступ до цілодобової телефонної гарячої лінії з метою порад та консультацій, а у робочий час - правову та психологічну допомогу, зв' язок із соціальними та іншими службами, розробку персонального плану реабілітації (виходячи з першочергових потреб потерпілої особи).

Для жертв домашньої злочинності у Швейцарії створено можливості звернення жертв до медичних закладів. Через особливості становища довіри до лікарів жертв, реалізується можливість порушити мовчання і подолати ізоляцію жертв насильства для притягнення винуватих до відповідальності.

Жертви домашньої злочинності у Швейцарії можуть отримати додаткову допомогу у вигляді психосоціальної чи психологічної підтримки [13]. У недержавному секторі за підтримки офіційних органів Швейцарії, спрямованих на протидію насильству в сім'ї, розроблено програму навчання проти насильства в шлюбі, сім’ї чи партнерстві з метою поліпшення захисту жертв, яка реалізовується у центрах допомоги потерпілих від насильства в сім'ї.

Цікавою з погляду на проблему запобігання домашній злочинності є досвід Ізраїлю, де фізичне покарання у сім'ї виключено. Будь-яке фізичне насильство принижує людину, а погроза застосування насильства вважається психологічним насильством і розцінюється як злочин [14, с. 250-251]. Відповідно до Закону Ізраїлю «Про запобігання домашньому насильству», прийнятого ще у 1991 р. (з подальшою редакцією у 2001 р.), не тільки чоловік має право звернутися до суду з проханням про отримання ордера на захист, щоб отримати заборону на проживання у квартирі (будинку) члена сім'ї, який виявляє насильство. У законі дається широке визначення члена сім'ї, що має право подати позов на отримання ордера на захист: розведений чоловік, бабуся чи дідусь, брати чи сестри, дитина чоловіка, брати і сестри чоловіка і дружини, дядьки і тітки, племінники, цивільне подружжя, а також пара однієї статі.

У Греції Закон «Про боротьбу із домашнім насильством» насамперед спрямований на захист основних прав жінок та дітей, протидію фізичному та сексуальному насильству, а також на забезпечення підтримки і допомоги жертвам домашнього насильства. Відповідно до його положень заподіяння шкоди здоров' ю (спричинення тілесних ушкоджень, побоїв тощо) у сім'ї вважається обтяжуючою обставиною (так само як і посягання на жінку, яка завідомо для винного перебуває у стані вагітності), криміналізовані сексуальне насильство відносно подружжя, інтимного партнера та тілесні покарання дітей, запроваджені заходи захисту (як юридичного, так і фізичного) жертв домашнього насильства, заборонний припис (згідно з яким виключається доступ кривдника для місця проживання / перебування жертви та (або) іiї близьких родичів, навчання дітей тощо) і програма психологічної корекції для кривдників [15, с. 12].

Донедавна суди Італії загальної юрисдикції не мали повноважень виносити приписи у справах про злочини в сім'ї. Проте після внесення змін до чинного Цивіль- 
ного кодексу вони мають право постановляти охоронний припис з метою захисту членів родини від кривдника: як запобіжний захід винна особа (подружжя, партнер чи інший родич) може бути невідкладно видалена 3 місця проживання у разі вчинення домашнього насильства і тільки за новим рішенням суду отримує право повернутись. Так само за умовами охоронного припису кривднику можуть заборонити відвідувати місця перебування (проживання, роботи) жертви та ії родичів (чи навіть наближатись до них).

Проблема домашньої злочинності є актуальною і для Франції. Статистичні дані за показниками виявів домашнього насильства змушують керівництво держави вживати кардинальних заходів для викорінення таких негативних тенденцій. У Франції проводиться активна робота з дослідження інтенсивності виявів домашнього насильства. Так, моніторинг ситуації виявів домашнього насильства у Франції започатковано досить давно і на теперішній час від 200 тис. до 2 млн жінок у Франції є жертвами домашньої злочинності, 400 - щорічно вмирають від побоїв, завданих чоловіком у сім'ї, тобто більше однієї жінки щодня [16].

Дослідження причин такої несприятливої ситуації у загалом благополучній Франції показує, що головними причинами високого стану домашньої злочинності є: відбиток патріархальних стереотипів домінування чоловіка у сім'ї, що особливо яскраво виявляється у традиційно мультикультурній та відкритій до імміграції Франції.

Висновки. Отже, вивчення зарубіжного досвіду та впровадження найкращих зарубіжних практик у вітчизняне правове поле допоможе Україні вирішити низку проблем, що виникають сьогодні в нашій країні у сфері запобігання домашній злочинності. Зокрема, йдеться про створення дієвого правового механізму захисту прав жертв домашньої злочинності в Україні, створення центрів допомоги жертвам домашньої злочинності у кожній територіальній громаді тощо.

\section{Список використаних джерел:}

1. Ковальова О.В. Діяльність служби дільничних інспекторів міліції щодо попередження насильства в сім'ї : дис. ... канд. юрид. наук : 12.00.07. Харків, 2008. 237 с.

2. Барбарош Л.М. Теоретико-методологічні підходи до розуміння поняття «домашня злочинність». Щорічні читання наукової школи «Інтелект»: матеріали міжнар. наук.-практ. конф. (Чернігів, 25 травня 2020 р.) / за заг. ред. І.Г. Богатирьова; Університет державної фіскальної служби України, 2020. С. 115-117.

3. Про ліквідацію всіх форм дискримінації щодо жінок: Конвенція ООН від 18 груд. 1979 p. URL: http:/ /zakon2.rada.gov.ua/laws/show/995_207 (дата звернення: 19.08.2020).

4. Конституція України: Закон України від 28 червня 1996 р. № 254к/96-BP. URL: https://zakon.rada.gov.ua/laws/show/254\%D0\%BA/96-\%D0\%B2\%D1\%80 (дата звернення: 19.08.2020).

5. Сягровец Е.В. Роль пекинской конференции 1995 г. и ее итоговых документов в формировании механизма реализации гендерного равенства на международном и национальном уровнях. Актуальные проблемы международного публичного и международного частного права: сб. науч. тр. Вып. 5. Минск, 2013. С. 75-86.

6. Бекетов О.И., Майле А.Д. Профилактические меры полицейского воздействия в системе мер противодействия домашнему насилию в государствах Европейского сообщества. Вестник Воронежского государственного университета. 2009. № 1(6). С. 420-431.

7. Seith C. Kinder und häusliche Gewalt. Herausforderungen an Behörden und Fachstel len. Soziale Sicherheit CHSS. 2009. № 5. S. 249-254. 
8. Domestic Abuse Guidelines for Prosecutors: Legal Guidance, Domestic abuse. CPS: вебсайт. URL: https://www.cps.gov.uk/legal-guidance/domestic-abuse-guidelines-prosecutors (дата звернення: 19.08.2020).

9. Domestic violence and abuse: help from DWP. Department for Work and Pensions and Home Office. Gov.uk: вебсайт. URL: https://www.gov.uk/government/publications/ domestic-violence-and-abuse-help-from-dwp (дата звернення: 19.08.2020).

10. Erturk Y. Implementation of general assembly resolution 60/251 of 15 march 2006 entitled "Human rights council". Report of the Special Rapporteur on violence against women, its causes and consequences. URL: http://evawglobal-database.unwomen.org/-/media/files/ un\%20women/vaw/country\%20 (дата звернення: 19.08.2020).

11. Restraining orders in Sweden An evaluation of the law, the new regulations, their implementations and effects: summary. URL: http://kunskapsbanken.nck.uu.se/ nckkb/nck/publik/fil/visa/31/br\% C3\% A5\% 20rapport\% 202007\% 202\% 20english\% 20 summary\%20restraining\%20orders\%20in\%20sweden.pdf (дата звернення: 19.08.2020).

12. Act on Violence against Women (Government Bill 1997/98 55). Global Database on Violence against Women. URL: http://evaw-global-database.unwomen.org/en/countries/ europe/sweden/1998/act-on-violence-against-women--governmentbill-1997-98-55 (дата звернення: 19.08.2020).

13. Häusliche Gewalt: Hilfe durch Ärzte entscheidend. Aerzteblatt.de : вебсайт. URL: https:/ / www.aerzteblatt.de/nachrichten/99199/Haeusliche-Gewalt-Hilfe-durch-Aerzteentscheidend (дата звернення: 19.08.2020).

14. Насилие в семье. Gov.il: вебсайт. URL: https://www.justice.gov.il/Ru/Units/ LegalAid/LegalAssistanceDomains/Pages/FamilyViolence.aspx (дата звернення: 19.08.2020).

15. Акімов М. Правове регулювання запобігання та протидії домашньому насильству в деяких державах Свропи. Новели законодавства про запобігання та протидію домашнъому насильству: матер. міжнар. круглого столу (Київ, 27 верес. 2019 р.). Київ : Національна академія прокуратури України, 2019. 184 с.

16. At least 2.000.000 women are victims of domestic violence in France. Sos femmes aсcиеil: вебсайт. URL: http:// www.sosfemmes.com/english_domestic_violence/violence_ statistics.htm (дата звернення: 19.08.2020). 
УДК 005:351.86:342(477)057.875

DOI https:// doi.org/10.32850/LB2414-4207.2020.14.22

\title{
ПОШУК НОВИХ СТАНДАРТІВ У ВИРІШЕННІ ПРОБЛЕМ СИСТЕМИ БЕЗПЕКИ УКРАЇНИ МАЙБУТНІМИ ПРАВООХОРОНЦЯМИ
}

\author{
Галунько Віра Миколаївна, \\ доктор юридичних наук, професор, \\ заступник декана \\ (Херсонський факультет Одеського \\ державного університету \\ внутрішніх справ, \\ м. Херсон, Україна)
}

У статті висвітлені основні підходи до пошуку нових стандартів у вирішенні проблем системи безпеки майбутніми правоохоронцями. Визначено, що у сучасному світі відбуваються зміни геополітичного простору, між державами змінюються сфери впливу, з'являються нові амбітні лідери, які ігнорують не тільки внутрішнє законодавство, а і норми міжнародного права, відбуваються військові конфлікти, що становлять загрозу безпеці всьому людству та порушують право на безпеку, що є базовим, фундаментальним для всієї системи прав. В Україні здебільшого використовується застаріла техніка, відсутня єдина інформаційна система для прикордонників, військових, служби безпеки, поліцейських тощо, наявний також корупщійний складник на найвищих рівнях влади, застарілі стандарти. Крім того, є проблема довіри до силових структур, до завдань яких віднесено забезпечення зовнішньої і внутрішньої безпеки. Тому передусім необхідно адаптувати національне законодавство національної безпеки до правових стандартів країн - членів Європейського Союзу та Організації Північноатлантичного договору та інформаційну інтеграцію починати з молоді, змінюючи ментальність людей, запроваджуючи нові стандарти Свропи в Україні. 3 урахуванням державної та регіональної політики заклад вищої освіти має надати майбутнім фахівцям-правоохоронцям вміння застосовувати заходи щодо забезпечення публічної безпеки. При цьому необхідно враховувати міжнародний досвід, особливо досвід НАТО. Тому особливу увагу слід приділяти практичним завданням, де відпрацьовувати нестандартні ситуації з урахуванням криміналістичних методів і засобів, знання яких дозволить передусім оперативним підрозділам, слідчим, дізнавачам чітко, оперативно орієнтуватися на місцях, приймати неординарні, але в межах чинного законодавства рішення.

Ключові слова: безпека, військові конфлікти, правоохоронні органи, правоохоронці, національна поліція. 


\title{
SEARCHING FOR NEW STANDARDS IN SOLVING PROBLEMS OF THE SECURITY SYSTEM OF UKRAINE BY FUTURE LAW ENFORCEMENT AGENTS
}

\author{
Halunko Vira Nikolaevna, \\ Doctor of Science of Law, Professor, \\ Deputy Dean \\ (Kherson Faculty of the Odessa State \\ University of Internal Affairs, \\ Kherson, Ukraine)
}

The article highlights the main directions for finding new standards in solving security problems by future law enforcement officers. It is determined that in the modern world there are changes in the geopolitical space, spheres of influence between states change, new ambitious leaders appear who ignore not only domestic law but also international law, military conflicts occur, which threaten the security of all mankind and violate the law. security, which is basic, fundamental to the whole system of rights. Ukraine mainly uses obsolete equipment, there is no single information system for border guards, the military, security services, police, etc., there is a corruption component at the highest levels of government, outdated standards. In addition, there is a problem of trust between law enforcement agencies, whose tasks include ensuring external and internal security. Therefore, first of all, it is necessary to adapt the national legislation of national security to the legal standards of the European Union and the North Atlantic Treaty Organization and information integration to start with young people, changing people's mentality by introducing new European standards in Ukraine. In line with national and regional policies, higher education should provide skills to future law enforcement professionals in the ability to apply public security measures, taking into account international experience, especially NATO. Therefore, special attention should be paid to practical tasks where to work out nonstandard situations, taking into account forensic methods and tools, knowledge of which will allow first of all, operational units, investigators, investigators to clearly, promptly navigate on the ground, make extraordinary decisions.

Key words: security, military conflicts, law enforcement agencies, law enforcement officers, national police.

Постановка проблеми. У сучасному світі відбуваються зміни геополітичного простору, між державами змінюються сфери впливу, з' являються нові амбітні лідери, які ігнорують не тільки внутрішнє законодавство, а і норми міжнародного права, відбуваються військові конфлікти, що становлять загрозу безпеці всьому людству та порушують право на безпеку, що є базовим, фундаментальним для всієї системи прав.

В умовах сьогодення Україна є предметом гібридних загроз, і не тільки через війну, а й через вибори, надзвичайні ситуації, продуктову безпеку, весь інформаційний простір тощо. Навколо держави сформувалися нові тенденції, які є джерелами значних загроз національній безпеці, територіальній цілісності, суверенітету, недоторканності. Особливої уваги потребують приграничні зони, як-то Херсонська, Харківська, Запорізька області, у яких агресивно настроєною державою активно застосовуються новітні технології у інформаційному просторі, дезінформуючи місцеве населення.

На жаль, в Україні в основному використовується застаріла техніка, відсутня єдина інформаційна система для прикордонників, військових, служби безпеки, поліцейських тощо. Наявний також корупційний складник на найвищих рівнях влади, застарілі стандарти. Крім того, є проблема довіри до силових структур, до завдань яких віднесено забезпечення зовнішньої і внутрішньої безпеки. Тому насамперед необхідно 
адаптувати національне законодавство національної безпеки до правових стандартів країн - членів Свропейського Союзу та Організації Північноатлантичного договору та інформаційну інтеграцію починати з молоді, змінюючи ментальність людей шляхом запровадження нових стандартів Свропи в Україні.

Аналіз останніх досліджень і публікацій. Питанням безпеки приділяли увагу багатьох науковців, як-от: В.В. Аброськін, А.В. Басов, О.М. Бандурка, Ю.П. Битяк, В.В. Гелетей, І.М. Доронін, Ю.В. Дубко, А.Т. Комзюк, С.О. Кузніченко, В.Я. Настюк, Г.О. Пономаренко, В.Б. Рушайло, В.Б. Рушайло, І.О. Шаповалова, Х.П. Ярмакі та інші. Однак вказане питання не втратило актуальності та потребує додаткового дослідження.

Мета статті - дослідити проблемні питання у системі безпеки та визначити новітні напрями їх усунення майбутніми правоохоронцями.

Виклад основного матеріалу. 32014 року Україна перебуває у реальній постійній загрозі щодо територіальної цілісності й суверенітету. На сході країни у проведенні антитерористичної операції та операції Об'єднаних сил беруть участь не тільки військові сили, а і правоохоронні органи. Експерти вважають, що Україні вдалося вирішити ряд проблем функціонування системи демократичного цивільного контролю над сектором безпеки, але для повноцінного забезпечення національних інтересів потрібно докласти ще багато зусиль, особливо для запровадження дієвих практичних інструментів контролю й подальшого наближення ситуації у цій сфері до загальноприйнятих демократичних норм» [1]. При цьому було виявлено найбільшу проблему - відсутність підготовлених фахівців, тому постало питання необхідності підготовки висококваліфікованих кадрів 3 широким спектром професійних компетентностей у сферах не тільки національної безпеки й оборони, а й у сфері забезпечення публічної безпеки тощо. При цьому особливого значення набуває саме відомча освіта.

Законом України «Про вищу освіту» віднесено до основних завдань закладу вищої освіти формування особистості шляхом патріотичного, правового, екологічного виховання, утвердження в учасників освітнього процесу моральних цінностей, соціальної активності, громадянської позиції та відповідальності, здорового способу життя, вміння вільно мислити та самоорганізовуватися в сучасних умовах; збереження та примноження моральних, культурних, наукових цінностей і досягнень суспільства [2].

3 урахуванням державної та регіональної політики заклад вищої освіти має надати навички майбутнім фахівцям-правоохоронцям у вмінні застосовувати заходи щодо забезпечення публічної безпеки при цьому необхідно враховувати міжнародний досвід, особливо НАТО. Більшість науковців схиляються до думки, що з урахуванням регіональних процесів безпека має будуватися на жорсткій протидії державі-агресору, що «передбачає створення гнучкого альянсу широкого кола демократичних держав та їх об'єднань. Свропейський Союз, сконцентрований на засобах «м'якої сили», $\epsilon$ неготовим діяти у ситуації застосування Росією засобів «жорсткої сили». Роль НАТО в нових умовах значно підвищується. В умовах необхідності протистояння «жорстким загрозам» НАТО стає основою європейської безпеки»[3]. Це підтверджується і навчаннями, що проводяться за участі сил НАТО на території нашої країни, де проходять навчання та ознайомлення з новітніми технологіями.

Крім того, останнім часом посилюється роль НАТО, яке починаючи з 2014 року із урахуванням досвіду країн - членів Альянсу надає Україні активну допомогу у ліквідації наслідків різних катастроф, процесі реформування силових структур України, вдосконаленні оборонних спроможностей, кібернетичній обороні, енергетичній без- 
пеці, медичній реабілітації, розмінуванні й утилізації вибухонебезпечних предметів. Крім того, підтримує постійні контакти з Міністерством закордонних справ, Міністерством оборони, Міністерством внутрішніх справ, Міністерством інформаційної політики України, Радою національної безпеки й оборони й іншими державними відомствами України. Як приклад - спільна ліквідація пожежі на складах боєприпасів у м. Балаклея Харківської області, знешкодження вибухонебезпечних предметів. Знання та оперативність у першочергових діях дозволили зберегти життя не тільки правоохоронців, а і місцевого населення.

Саме такі знання необхідні майбутнім правоохоронцям. Тому особливу увагу слід приділяти практичним завданням, де відпрацьовувати нестандартні ситуації з урахуванням криміналістичних методів і засобів, знання яких дозволить насамперед оперативним підрозділам, слідчим, дізнавачам чітко, оперативно орієнтуватися на місцях, приймати неординарні, але в межах чинного законодавства, рішення.

Висновки. Вивчаючи дисципліни, пов' язані з інтернет ресурсами, необхідно ввести як додаткові дисципліни ознайомлення майбутніх поліцейських і новітні розробки в сфері IT, які діють та можуть бути застосовані правопорушниками, а також методи й заходи, що дозволяють їх блокувати. Під час вивчення та отримання певних навичок щодо захисту від зовнішніх посягань курсанти повинні мати навички адекватно припиняти злочинні дії особою, особливо у разі проявлення агресивної поведінки. Як, наприклад, навчання, що заплановано на 5-9 жовтня 2020 в м. Одесі, де будуть відпрацьовуватись алгоритми дій, що можуть виникнути у кризових ситуаціях, щоб вчасно, грамотно та злагоджено реагувати на кібератаки, захоплення транспортних шляхів тощо.

\section{Список використаних джерел:}

1. Поляков Л., Козій I. Реформа демократичного цивільного контролю над Збройними Силами та іншими військовими формуваннями в Україні: наступні кроки. URL: http:/ / www.ieac.org.ua/public/item/68-reforma-demokratychnoho-tsyvilnoho-kontroliu-nad-zbroinymy-sylamy-ta-inshymy-viiskovymy-formuvanniamy-v-ukraini-nastupni-kroky (дата звернення 02.09.20 20).

2. Про вищу освіту. Закон України.URL. https://zakon.rada.gov.ua/laws/ show/1556-18\#Text (дата звернення 02.09.2020).

3. Актуальні виклики та загрози регіональній безпеці: висновки для України / Б.О. Парахонський, Г.М. Яворська; за заг. ред К.А. Кононенка. Київ : НІСД, 2014. 48 с. 
DOI https:// doi.org/10.32850/LB2414-4207.2020.14.23

\title{
ТЕОРЕТИКО-ПРИКЛАДНІ ПЕРЕДУМОВИ ДОСЛІДЖЕННЯ ЗАРУБІЖНОГО ДОСВІДУ ЗАПОБІГАННЯ ВЧИНЕННЮ ДЕРЖАВНИМИ СЛУЖБОВЦЯМИ КОРУПЦЙНИХ ЗЛОЧИНІВ
}

\author{
Довбань Ігор Миколайович, \\ кандидат юридичних наук \\ (м. Київ, Україна)
}

У статті наведено теоретико-прикладні передумови дослідження зарубіжного досвіду запобігання вчиненню державними службовцями корупційних злочинів. Наголошено на необхідності врахування в процесі проведення порівняльних кримінологічних досліджень таких світових закономірностей теорії та практики боротьби зі злочинністю, як плюралізм у підходах до пошуку причин злочинної поведінки, пріоритет соціологічних концепцій детермінації злочинності; інтернаціоналізація заходів боротьби зі злочинністю на теоретичному й практичному рівні, що проявляється в спробах створення міжнародної кримінології та розширенні міжнародного співробітництва держави в галузі практичної протидії кримінальним реаліям, що становлять загрозу всій світовій спільноті.

Зазначено, що поряд із наявністю відмінностей беззаперечний факт схожості злочинів, що вчиняються державними службовцями в різних країнах, - це їхня підвищена суспільна небезпечність, зважаючи на те, що відповідні злочини вчиняються особами, покликаними протидіяти злочинності загальносоціальними й спеціально-кримінологічними заходами. Це, відповідно, засвідчує найвищий ступінь правового нігілізму, цинізму й дискредитації апарату держави в очах суспільства. За таких обставин постає потреба щодо ефективної реалізації в правоохоронній, судовій і кримінально-виконавчій практиці триєдиного принципу невідворотності кримінальної відповідальності, призначення, виконання та відбування покарань державними службовцями, винними у вчиненні злочинів. Тому як чинний закон України про кримінальну відповідальність, так і законодавства зарубіжних країн передбачають низку несприятливих кримінально-правових наслідків щодо осіб, винних у вчиненні корупційних злочинів.

Зроблено висновок, що дослідницький процес вивчення зарубіжного досвіду запобігання вчиненню державними службовцями корупційних злочинів має враховувати не лише широту географічного критерію, а й критерії функціональності й раціональності, національні й соціокультурні особливості, а також грунтуватися на методологічних підходах, спроможних забезпечити повноту, об'єктивність та ефективність відповідного наукового пошуку.

Ключові слова: теоретико-прикладні передумови, кримінолого-правова система України, зарубіжний досвід, запобігання, корупційні злочини, державні службовці. 


\title{
THEORETICAL AND APPLIED PRECONDITIONS FOR THE STUDY OF FOREIGN EXPERIENCE IN PREVENTING CORRUPTION CRIMES COMMITTING BY PUBLIC SERVANTS
}

\author{
Dovban Ihor Mykolaiovych, \\ Candidate of Law Sciences \\ (Kyiv, Ukraine)
}

The article presents theoretical and applied preconditions for the study of foreign experience in preventing corruption crimes committing by public servants. Emphasis is placed on the need to take into account when conducting comparative criminological studies such global patterns of theory and practice of combatting criminality as: pluralism in approaches to finding the causes of criminal behavior, the priority of sociological concepts of crime determination; internationalization of measures to combat criminality at the theoretical and practical level, which is manifested in attempts to create international criminology and expand international cooperation in the field of practical counteraction to criminal realities that pose a threat to the world community.

It is noted that along with the differences, the fact of similarity of crimes committed by public servants in different countries is indisputable - it is their increased public danger, given that such crimes are committed by persons called to combat criminality by social and special criminological measures. This, accordingly, testifies to the highest degree of legal nihilism, cynicism and discrediting of the state apparatus in the eyes of society. In such circumstances, there is a need for effective implementation in law enforcement, judicial and criminal-executive practice of the threefold principle of inevitability of criminal liability, appointment, execution and serving of sentences by public servants guilty of committing crimes. Therefore, both the current law of Ukraine on criminal liability and the legislation of foreign countries provide for a number of adverse criminal consequences for persons guilty of corruption crimes committing.

It is concluded that the research process of studying foreign experience in preventing corruption crimes committing by public servants should take into account not only the breadth of geographical criteria, but also the criteria of functionality and rationality, national and sociocultural features, and should base on methodological approaches that can ensure completeness, objectivity and efficiency of the relevant scientific research.

Key words: theoretical and applied preconditions, criminological and legal system of Ukraine, foreign experience, preventing, corruption crimes, public servants.

Постановка проблеми. Натепер у кримінологічній науці виділяють низку світових закономірностей теорії та практики боротьби зі злочинністю: плюралізм у підходах до пошуку причин злочинної поведінки, пріоритет соціологічних концепцій детермінації злочинності; інтернаціоналізація заходів боротьби зі злочинністю на теоретичному й практичному рівні, що проявляється в спробах створення міжнародної кримінології та розширенні міжнародного співробітництва держави в галузі практичної протидії кримінальним реаліям, що становлять загрозу всій світовій спільноті. Таке явище є відбиттям загальносвітового процесу зближення правових систем [1].

За таких обставин актуалізується необхідність вивчення зарубіжного досвіду запобігання злочинам (особливо корупійним), що вчиняються державними службовцями, й окреслення перспектив його впровадження в Україні. Відповідні гносеологічні процеси потребують свого теоретико-методологічного обгрунтування в контексті процесів глобалізації та зближення правових систем світу щодо боротьби зі злочинністю у світовому масштабі, розвитку міжнародних організацій і різних форм взаємодії за цим напрямом. 
Аналіз останніх досліджень і публікацій. Актуальним проблемам запобігання вчиненню державними службовцями корупційних злочинів як в Україні, так і в зарубіжних країнах, присвячені наукові доробки таких вітчизняних і зарубіжних кримінологів: В.С. Батиргареєвої, І.Г. Богатирьова, О.Ю. Бусол, В.В. Голіни, Б.М. Головкіна, А.Л. Гуринської, І.М. Даньшина, С.Ф. Денисова, Т.А. Денисової, О.М. Джужі, А.І. Долгової, В.М. Дрьоміна, А.П. Закалюка, А.Ф. Зелінського, О.Г. Кальмана, I.I. Карпеця, I.М. Клеймьонова, О.Г. Колба, І.М. Копотуна, О.М. Костенка, В.М. Кудрявцева, О.М. Литвака, О.М. Литвинова, В.В. Лунєєва, В.К. Максимова, О.А. Мартиненка, М.I. Мельника, В.А. Мисливого, П.П. Михайленка, А.А. Музики, О.В. Старкова, В.О. Тулякова, В.I. Шакуна й інших.

Водночас низка теоретико-методологічних і прикладних питань, пов'язаних зі сприйняттям зарубіжного досвіду запобігання вчиненню державними службовцями корупційних злочинів, зважаючи на специфіку кримінолого-правової системи України, натепер розроблені не в повному обсязі.

Постановка завдання. Метою статті $є$ теоретико-прикладне обгрунтування використання кримінолого-правовою системою України зарубіжного досвіду запобігання вчиненню державними службовцями корупційних злочинів.

Виклад основного матеріалу дослідження. Злочинність серед державних службовців є розповсюдженим явищем у всьому світі через найпоширеніший іï вияв - корупційну злочинність, з огляду на що на міжнародному рівні (конференції, конгреси, конвенції) вона визнана «епідемією» в більшості країн. Історія цього виду злочинності досить давня, оскільки криється в механізмі задоволення особистих інтересів шляхом зловживання посадовим становищем, виконуючи відповідну функцію держави. За таких обставин можна стверджувати, що злочинність державних службовців виникає з моменту формування апарату держави й поставлення відповідних правовідносин під кримінально-правову охорону шляхом криміналізації відповідних суспільно небезпечних діянь. За таких обставин вказаний вид злочинності набував якісної та кількісної специфіки на різних етапах державотворення країн світу [2, с. 102].

Поряд із наявністю відмінностей, беззаперечним є факт схожості злочинів, що вчиняються державними службовцями в різних країнах, - це їхня підвищена суспільна небезпечність, зважаючи на те, що відповідні злочини вчиняються особами, покликаними протидіяти злочинності загальносоціальними й спеціально-кримінологічними заходами. Це, відповідно, засвідчує найвищий ступінь правового нігілізму, цинізму й дискредитації апарату держави в очах суспільства. За таких обставин постає потреба щодо ефективної реалізації в правоохоронній, судовій і кримінально-виконавчій практиці триєдиного принципу невідворотності кримінальної відповідальності, призначення, виконання та відбування покарань державними службовцями, винними у вчиненні злочинів. Тому як чинний закон України про кримінальну відповідальність, так і законодавства зарубіжних країн передбачають низку несприятливих кримінально-правових наслідків щодо осіб, винних у вчиненні корупційних злочинів.

Водночас, зважаючи на ту обставину, що в зарубіжній кримінології не існує окремого розділу, що займається вивченням саме злочинності державних службовців загалом, доречно під час відповідних компаративних досліджень використовувати зарубіжні доробки щодо формування антикорупційних стратегій у сфері державної служби й запобігання посадовій і службовій злочинності.

Тому, спираючись на наявні в сучасній порівняльній кримінології підходи, можна навести такі теоретико-прикладні передумови дослідження зарубіжного досвіду запобігання вчиненню державними службовцями корупційних злочинів: 
1. Ефективність функціонування державної служби й роботи державних службовців (у тому числі невчинення ними корупційних злочинів) чинить вагомий вплив на різні індикатори, за якими на міжнародній арені визначаються рівень розвитку й імідж держави. До таких основних глобальних індикаторів стану кримінологічної обстановки, що запроваджені в міжнародну практику, належать: Індекс якості державного управління, Індекс сприйняття корупції, Індекс верховенства права, Глобальний індекс недієздатності держав.

2. Кримінолого-правова система України, незважаючи на відому специфіку, зумовлену особливостями законодавства, національним менталітетом, кількісно-якісними показниками й відмінними рисами злочинності, вирізняючись єдністю трьох взаємопов'язаних компонентів (теоретична основа, кримінологічне законодавство, практика запобігання злочинності), володіє невіддільними ознаками, властивими відомим світовим кримінолого-правовим системам.

Українська кримінолого-правова система належить до кримінолого-правових систем слов' янської правової сім'ї, яким властиві такі риси:

1) тісний зв'язок традиційної основи права й держави зі специфікою православної гілки християнства з їі акцентами не на мирському життєрозумінні Бога й людини (католицизм) і тим більше не на благословенні користолюбства (протестантизм), а на духовному житті людини з відповідними етичними висновками (некористолюбство, благочестя і так далі).

Християнська мораль вище людських законів. Юридичні закони вивіряються за моральними мірками, підкоряються їм. У такому контексті будь-який закон має відповідати критерію християнської моральності, а не суперечити йому. 3 православного боку закон завжди покликаний забезпечувати справедливість і протидіяти злу. Право містить у собі певний мінімум моральних норм, обов' язкових для всіх членів суспільства [3, с. 296-298];

2) призначення держави полягає в тому, щоб обмежувати зло й стверджувати добро утримувати світ від смути й хаосу, поділу й ненависті, упередженості й несправедливості, беззаконня та брехні, розтління та морального розпаду [3, с. 298]. В Україні повною мірою реалізується ця ознака через проголошення ії суверенною та незалежною, демократичною, соціальною, правовою державою (ст. 1 Конституції) та визнання головним обов'язком держави утвердження та забезпечення прав і свобод людини (ч. 2 ст. 3 Конституції) [4];

3) заперечення слов' янською правовою культурою легалізму (юридизму) західноєвропейської правової традиції, панування архетипів народного правосуддя, в якому судити «по совісті» важливіше, ніж «судити по закону».

Архетип справедливості, який притаманний слов'янській правосвідомості, вище юридичного поняття законності, по-перше, тому, що закон спирається на букву, а не на дух, i, по-друге, тому, що він частіше знаходиться на стороні сильного й багатого [3, с. 298-299].

Зазначена ознака з плином часу набула своєї видозміни, й натепер легалізм домінує над духом справедливості, оскільки багато норм чинного законодавства або декларативні, або їх реалізація в соціально корисних цілях обмежена низкою інших законодавчих запобіжників, серед яких чільне місце посідає прив'язка до фінансування тих або інших напрямів у державному бюджеті. Щодо панування архетипів народного правосуддя, то вони за всю історію Української державності набували якісно відмінних рис. Якщо говорити про не набагато віддалені державні режими, то характерна для радянського ладу система народного правосуддя (з домінуванням інституту народних судів) за часів незалежності України набула нової форми, збе- 
рігши такий інститут представницької демократії (участі народу) в здійсненні правосуддя, як присяжні (ч. 3 ст. 5 Закону України «Про судоустрій і статус суддів» від 02 червня 2016 р. № 1402-VIII) [5]. Попередній Закон України «Про судоустрій і статус суддів» від 07 липня 2010 р. № 2453-VI передбачав у визначених законом випадках реалізацію судової влади, окрім професійних суддів і присяжних, також народними засідателями шляхом здійснення правосуддя в рамках відповідних судових процедур (ч. 2 ст. 1) [6].

Натепер правила судити «по совісті» й «судити по закону» застосовуються як паритетні, на що вказує найперший обов' язок судді, вміщений у п. 1 ч. 7 ст. 56 Закону України «Про судоустрій і статус суддів» 2016 р., - справедливо, безсторонньо й своєчасно розглядати й розв'язувати судові справи вidnobidно до закону з дотриманням засад і правил судочинства (курсив наш - I. Д.). Схожі положення містяться і в тексті присяги судді (ч. 1 ст. 57 зазначеного Закону);

4) вершиною теорії слов' янської правової сім'ї є вчення про симфонію влад: світської та духовної. Вчення про симфонію влад (державної та церковної) накладало тягар відповідальності на обидві сторони. Держава повинна була відповідати імперативу «порядності»: по-перше, мати «правильний» політичний режим, до якого не належить ні олігархія, ні диктатура; по-друге, компетентно вести державні справи; по-третє, виконувати моральні заповіді. Церква стояла на сторожі моральних підвалин держави, безпосередньо беручи участь у справах виховання народу, а також звертаючись у необхідних випадках зі словами повчання або навіть осуду до представників верховної влади [3, с. 299-300];

5) візантійські коріння слов' янської державності й правових основ. Водночас вчені відзначають тут обставину, що право країн слов'янської правової сім'ї через право римсько-візантійсько-грецьке своєрідним «кружним» шляхом історично перетнулося з романо-германською правовою сім'єю, і ці дві течії європейської (євроазіатської) правової культури приречені на спільне, але кожна - на самостійне життя, створюючи одна для одної інноваційні альтернативи розвитку [3, с. 300-301];

6) прагнення до втілення принципів громадськості, колективізму, соборності [3, c. 301].

Зрозуміло, що деякі з ознак слов' янської правової сім'ї, котрі визначали ії самобутність протягом кількох століть, із плином часу видозмінилися через такі обставини:

- майже 70 років домінування радянської влади з ії ідеологією, котра грунтувалася на засадах атеїзму, суттєво похитнули християнські засади зазначеної правової сім'ї;

- входження України до ряду міжнародних організацій і визнання євроінтеграційного вектора іiі розвитку у XXI ст. робить неминучими процеси сприйняття слов'янською правовою культурою легалізму (юридизму) західноєвропейської правової традиції. Нині велика кількість чинних міжнародних договорів, згода на обов' язковість яких надана Верховною Радою України, увійшла органічною частиною до національного законодавства України, що засвідчено на рівні ч. 1 ст. 9 Конституції України [4], ч. 1 ст. 19 Закону України «Про міжнародні договори України» [7], галузевого законодавства й відповідних законів про ратифікацію;

- трансформація суспільних відносин, починаючи з 1990-х рр., із супутніми процесами роздержавлення, приватизації тощо суттєво похитнули принципи громадькості, колективізму, соборності, які протягом століть визначали самобутність слов' янської правової сім'ї.

Доречні судження зарубіжного кримінолога I.M. Клеймьонова, що громадскість, колективізм, соборність - антиринкові принципи, тому поспішне будівництво капіталізму на пострадянському просторі суперечить менталітету слов' янських народів 
і не має далекої перспективи [3, с. 301]. У такій позиції ми вбачаємо одну з головних проблем усвідомлення державою теоретико-прикладного значення кримінологічних досліджень. Сучасні суспільно-політичні процеси засвідчують той факт, що владні рішення не завжди враховують кримінологічні рекомендації та прогнози, наслідком чого є розвиток загальносоціальних і спеціальних (галузевих) детермінант злочинності. Зокрема, процеси роздержавлення та приватизації більшості сфер народного господарства, що відбулися в Україні протягом 1990-х - на початку 2000-х рр., не створили анонсованого збільшення робочих місць, а навпаки, призвели до збільшення безробіття, котре виступає загальносоціальною детермінантою злочинності в Україні.

Зважаючи на вищевикладене, є підстави констатувати, що сучасний етап побудови в Україні кримінолого-правової системи в умовах реформування суспільних інститутів, системи державних (у тому числі правоохоронних) органів, децентралізації має враховувати як позитивні історичні традиції, що формувалися на засадах справедливості й християнської моральності, так і уніфікацію з кримінолого-правовими системами провідних країн світу, що зумовлено розвитком міжнародного співробітництва в галузі боротьби зі злочинністю та виконанням Україною взятих на себе зобов' язань у цій сфері.

3. В умовах розбудови в Україні правової держави актуалізується пошук оптимальних стратегій державної політики у сфері боротьби зі злочинністю, орієнтованих на кращий зарубіжний досвід.

Тому варто навести такі методологічні підходи, важливі в процесі застосування компаративного методу у вивченні зарубіжного досвіду запобігання вчиненню державними службовцями корупційних злочинів:

- по-перше, це урахування національних особливостей, оскільки в Україні не набули широкого розвитку (більшою чи меншою мірою) східні підходи до виховання особистості з опорою на моральні принципи, як і західні стандарти активності інститутів громадянського суспільства. Хоча на необхідності розвитку моральних засад запобіжної діяльності наголошує такий відносно молодий напрям, як християнська кримінологія. У контексті цього нового кримінологічного напряму доречне судження вітчизняного кримінолога, професора І.Г. Богатирьова: «Якщо для запобігання корупційної злочинності застосувати належним чином засоби масової інформації, можна виховати покоління людей, у правовій свідомості яких немає місця корупції. По суті идеться про формування такої християнської ідеології запобігання корупції, яка сповідатиме заборону корупційним відносинам, створить умови позитивного впливу на зміну менталітету нації щодо проявів корупції в суспільстві» [8, с. 170].

Водночас урахування моральних підвалин українського народу, що протягом століть впливали на формування вищенаведених елементів самобутності слов'янської правової сім'ї, доцільне для формування антикорупційної культури державних службовців.

Своєю чергою розвиток західних моделей функціонування інститутів громадянського суспільства (й підвищення ролі громадськості в контролі за діяльністю органів державної влади) виступає потужним загальносоціальним заходом запобігання злочинам, що вчиняються державними службовцями;

- по-друге, поряд з урахуванням національних і соціокультурних особливостей важливого значення набуває функціональний критерій - це позитивний досвід зарубіжних антикорупційних практик (стратегій). Водночас зазначений досвід має враховувати й критерій раціональності. Тобто якщо країна є демократичною за формою державного (політичного) режиму (Україна), вона не повинна наслідувати репресивні практики реагування на факти корупції, наявні в країнах 3 антидемо- 
кратичним (тоталітарним, авторитарним) політичним режимом (наприклад, застосування смертної кари за корупційні злочини в Китайській Народній Республіці). Одним із таких критеріїв може стати рейтинг країн за Індексом сприйняття корупції, а також за результатами структурних перетворень, які у відповідних державах (що підлягають компаративному дослідженню) створили передумови для успішного економічного зростання;

- по-третє, в зарубіжних країнах не публікується офіційна статистика щодо загальної кількості й розподілу за родовими об'єктами й постатейним принципом злочинів, що вчиняються державними службовцями, що ускладнює пошук і групування отриманих кримінологічних показників;

- по-четверте, відмінності в термінології, нормативно-правовому забезпеченні, системі суб'єктів запобігання злочинам у сфері державної служби тощо.

Висновки. Отже, дослідницький процес вивчення зарубіжного досвіду запобігання вчиненню державними службовцями корупційних злочинів має враховувати не лише широту географічного критерію, а й критерії функціональності й раціональності, національні й соціокультурні особливості, а також грунтуватися на методологічних підходах, спроможних забезпечити повноту, об'єктивність та ефективність відповідного наукового пошуку.

\section{Список використаних джерел:}

1. Наумов А.В. Сближение правовых систем как итог развития уголовного права XX века и его перспектив в XXI веке. Государство и право. 1998. № 6. С. 50-58.

2. Довбань I.M. Злочинність державних службовців як цілісний комплексний феномен. Південноукрайнський правничий часопис. 2019. № 4. Ч. 1. С. 102-104.

3. Клейменов И.М. Сравнительная криминология : монография. Москва : Норма: ИНФРА-М, 2012. 368 с.

4. Конституція України : Закон України від 28 червня 1996 р. № 254к/96-ВР / Верховна Рада України. Відомості Верховної Ради Украӥни. 1996. № 30. Ст. 141.

5. Про судоустрій і статус суддів : Закон України від 02 червня 2016 р. № 1402-VIII / Верховна Рада України. Відомості Верховної Ради Украӥни. 2016. № 31. Ст. 545.

6. Про судоустрій і статус суддів : Закон України від 07 липня 2010 р. № 2453-VI / Верховна Рада Украйни. Відомості Верховної Ради України. 2010. № 41-42, № 43, № 44-45. Ст. 529.

7. Про міжнародні договори України : Закон України від 29 червня 2004 р. № 1906-IV / Верховна Рада України. Відомості Верховної Ради України. 2004. № 50. Ст. 540.

8. Богатирьов I.Г. Кримінологія : підручник / за заг. ред. І.Г. Богатирьова, В.В. Топчія. Київ : ВД «Дакор», 2018. 352 с. 


\title{
КРИМІНАЛЬНИЙ ПРОЦЕС ТА КРИМІНАЛІСТИКА; ОПЕРАТИВНО-РОЗШУКОВА ДІЯЛЬНІСТЬ
}

\author{
УДК 343.123+343.132 \\ DOI https:/ / doi.org/10.32850/LB2414-4207.2020.14.24

\section{ПРОБЛЕМНІ ПИТАННЯ РЕАЛІЗАЦІЇ ПРОЦЕСУАЛЬНИХ ПОВНОВАЖЕНЬ ДЕТЕКТИВА НАБУ В РАЗІ ВИТРЕБУВАННЯ РЕЧЕЙ ТА ДОКУМЕНТІВ}

\author{
Гейко Олексій Володимирович, \\ аспірант \\ (Національна академія Служби \\ безпеки України, \\ м. Київ, Україна), \\ старший детектив \\ (Національне антикорупційне \\ бюро України, \\ м. Київ, Україна)
}

Статтю присвячено дослідженню наукової літератури, нормативного врегулювання та правозастосовної практики стосовно способів витребування речей та документів як джерел доказів. Акцентується окрема увага на наявності низки проблемних питань, пов' язаних як із законодавчим упорядкуванням, так і правозастосовним механізмом витребування відомостей, документів і речей, а також тимчасовим доступом до них в порядку, передбаченому Главою 15 КПК України, наявність яких знижує ефективність здійснення досудового розслідування та негативно впливає на виконання завдань кримінального провадження.

3 урахуванням викладеного автором статті поставлено за мету вивчення актуального стану наукової та правової регламентації способів витребування речей та документів як джерел доказів, дослідження проблемних питань, які пов'язані із практичним використанням таких процесуальних інструментів, та надання науково обгрунтованих пропозицій та рекомендацій щодо їх усунення.

Робиться висновок відносно законності повноважень детективів Національного антикорупційного бюро України щодо витребування речей, документів та інших відомостей як способу збирання доказів у формі письмової вимоги, складеної відповідно до ст. 93 КПК України. Звертається увага на необхідність детального законодавчого урегулювання порядку та підстав складання та використання такої вимоги, нормативного закріплення ії форми та змісту, визначення порядку та строків ії виконання, відповідальності за ії невиконання тощо.

Пропонуються шляхи вдосконалення законодавчої регламентації звернення детектива до слідчого судді із клопотанням про тимчасовий доступ до речей та документів, виділивши як виключні підстави для такого звернення: 
- необхідність у отриманні тимчасового доступу до оригіналів речей та документів;

- необхідність у отриманні тимчасового доступу до речей та документів (копій або оригіналів), які містять у собі охоронювану законом таємницю.

Ключові слова: Національне антикорущійне бюро України, слідчий, детектив, досудове розслідування, витребування речей та документів, тимчасовий доступ до речей та документів, збирання доказів.

\title{
PROBLEMATIC ISSUES OF THE EXERCISE OF PROCEDURAL POWERS OF THE DETECTIVE OF NABU DURING REQUESTING FOR OBJECTS AND DOCUMENTS
}

\author{
Geiko Oleksii Volodymyrovych, \\ Postgraduate Student \\ (National Academy of Security Service of \\ Ukraine, Kyiv, Ukraine), \\ Senior Detective \\ (National Anti-Corruption \\ Bureau of Ukraine, \\ Kyiv, Ukraine)
}

The article is devoted to the discovering of scientific literature, regulations and law enforcement practices regarding the methods of requesting for objects and documents as sources of evidence. Particular attention is paid to the existence of a number of problematic issues related to both legislation and law enforcement mechanism for requesting information, documents and objects, as well as temporary access to them under procedure outlined in Chapter 15 of the CPC of Ukraine, which reduce the effectiveness of pre-trial investigation and negatively affect the performance of tasks of criminal proceedings.

In accordance with the foregoing, the author of the article aims to study the current state of scientific and legal regulation of methods of requesting for objects and documents as sources of evidence, research of problematic issues related to the practical use of such procedural tools and providing scientifically grounded proposals and recommendations for their elimination.

A conclusion is made regarding the legality of the powers of detectives of the National Anti-Corruption Bureau of Ukraine to request for objects, documents and other information as a way of gathering evidence, in the form of a written request drawn up in accordance with Art. 93 of the Criminal Procedure Code of Ukraine. Attention is paid to the need for detailed legislative regulation of the procedure and grounds for drafting and using such request, normative consolidation of its form and content, determining the procedure and deadlines for its implementation, liability for non-compliance, etc.

There are ways to improve the legal regulation of the detective's appeal to the investigating judge with a motion for temporary access to objects and documents, highlighting as exclusive grounds for such an appeal:

- the need to obtain temporary access to the originals of documents;

- the need to obtain temporary access to objects and documents (copies or originals) that contain a secret protected by law.

Key words: National Anti-Corruption Bureau of Ukraine, investigator, detective, pretrial investigation, requesting for objects and documents, temporary access to objects and documents, evidence gathering.

Усунення неоднозначного тлумачення окремих положень Кримінального процесуального кодексу України має сприяти уніфікованим підходам їх практичного застосування. 
3 огляду на сформовану практику здійснення досудового розслідування положення КПК України недостатньо чітко регулюють питання кримінального провадження, що стосуються збирання доказів стороною обвинувачення шляхом витребування відомостей, документів і речей, а також тимчасового доступу до них в порядку, передбаченому Главою 15 КПК України.

3 огляду на це дослідження положень КПК України, які стосуються процесуальних форм витребування речей та документів, набуває неабиякої актуальності, що зумовлено потребою у виявленні недоліків їх нормативно-правової регламентації та розробці пропозицій щодо їх усунення.

Окремі питання щодо процедур витребування речей та документів розглядали у своїх роботах С.В. Андрусенко, О.С. Божко, І.В. Гловюк, С.О. Ковальчук, М.А. Погорецький, М.С. Руденко, І. В. Сліпченко, М.Є. Шумило та ін. В той же час сьогодні вказані засоби отримання доказів недостатньо чітко врегульовані діючим кримінально-процесуальним законодавством, що знижує ефективність проведення досудового розслідування та ставить під загрозу виконання завдань кримінального провадження. В зв'язку з викладеним питання щодо правового урегулювання процедур витребування речей та документів потребують подальшого дослідження й розроблення пропозицій щодо їх нормативного регламентування та удосконалення з урахуванням діючих механізмів кримінального процесу України.

Метою статті $є$ вивчення актуального стану правової регламентації способів витребування речей та документів як джерел доказів, висвітлення проблем, які пов'язані із практичним використанням таких процесуальних інструментів, та надання пропозицій та рекомендацій щодо їх усунення.

Чинний Кримінальний процесуальний кодекс України одним із завдань кримінального провадження визначає забезпечення швидкого, повного та неупередженого розслідування і судового розгляду з тим, щоб кожний, хто вчинив кримінальне правопорушення, був притягнутий до відповідальності згідно зі своєю виною, жоден невинуватий не був обвинувачений або засуджений, жодна особа не була піддана необгрунтованому процесуальному примусу, і щоб до кожного учасника кримінального провадження була застосована належна правова процедура.

Ефективність досудового розслідування може бути забезпечена шляхом належного здійснення кримінального процесуального доказування. Це підтверджує той факт, що доказування та докази є одними із найважливіших правових засобів у реалізації завдань кримінального провадження.

Як слушно зазначає М.С. Шумило, цінність процесуальних доказів полягає в тому, що вони є основними засобами доказування існування / неіснування юридично значимих фактів і обставин, визначених предметом доказування в кримінальному провадженні, створюючи тим самим надійну фактову основу для прийняття різноманітних процесуальних рішень [1, с. 95].

У загальному вигляді способи збирання доказів стороною обвинувачення закріплені у ч. ч. 2 і 4 ст. 93 КПК України, аналіз якої дозволяє виділити такі способи: 1) проведення слідчих (розшукових) дій; 2) проведення негласних слідчих (розшукових) дій; 3) витребування від органів державної влади, органів місцевого самоврядування, підприємств, установ та організацій, службових та фізичних осіб речей, документів, відомостей; 4) отримання речей і документів від учасників кримінального провадження; 5) отримання висновків експертів; 6) отримання висновків ревізій та актів перевірок; 7) проведення інших процесуальних дій, передбачених КПК України; 8) одержання на території іноземної держави в результаті здійснення міжнародного співробітництва під час кримінального провадження. 
На практиці під час здійснення досудового розслідування досить часто виникають проблеми з реалізацією детективами НАБУ своїх процесуальних повноважень у частині витребування від органів державної влади, органів місцевого самоврядування, підприємств, установ та організацій, службових та фізичних осіб речей, документів, відомостей. Досить часто володілець зазначених джерел доказів відмовляє у їх наданні. У більшості таких випадків підставою для відмови у наданні речей та документів стає посилання на відсутність у детективів повноважень на витребування речей та документів без дотримання процедури звернення до слідчого судді із клопотанням про тимчасовий доступ до речей і документів та отримання відповідної ухвали суду.

Причиною виникнення таких проблем $є$ переконання ряду науковців і практикуючих юристів у тому, що зазначені повноваження сторони обвинувачення недостатньо урегульовані чинним КПК України, відповідно, відсутність належної правової регламентації процедури та порядку витребування речей та документів має за собою такий наслідок, як відсутність обов'язку виконання подібних вимог.

Слід погодитись, що процедура витребування речей, документів та відомостей дійсно нечітко врегульована чинним кримінально-процесуальним законодавством, однак, зробивши детальний аналіз його норм, ми доходимо висновку, що детективи НАБ України, як і слідчі інших органів досудового розслідування, мають повноваження на таке витребування, а фізичні та юридичні особи, яких це стосується, - відповідний обов' язок виконувати законні вимоги детектива задля сприяння виконання останнім завдань кримінального провадження.

У ч. 6 ст. 9 КПК України зазначено, що у випадках, коли положення КПК не регулюють або неоднозначно регулюють питання кримінального провадження, застосовуються загальні засади кримінального провадження, визначені частиною першою статті 7 КПК України.

Згідно із ч. 5 ст. 40 КПК України органи державної влади, органи місцевого самоврядування, підприємства, установи та організації, службові особи, інші фізичні особи зобов' язані виконувати законні вимоги та процесуальні рішення слідчого.

Кодексом України про адміністративні правопорушення передбачені певні механізми правового впливу та юридичної відповідальності за невиконання законних вимог детектива. Так, зокрема, статтею 185-4 КУпАП передбачено адміністративну відповідальність за злісне ухилення свідка, потерпілого, експерта, перекладача від явки до органів досудового розслідування під час досудового розслідування [2]. Окремою нормою, а саме статтею 185-13 КУпАП, встановлено адміністративну відповідальність за невиконання законних вимог посадових осіб Національного антикорупційного бюро України, яке може полягати у ненаданні інформації Національному антикорупиіиіному бюро України на запит його посадових осіб, наданні завідомо недостовірної інформації чи не $b$ повному обсязі, порушення встановлених законом строків ї̈ надання, повідомлення третіх осіб стосовно того, що про них збирається така інорормачія, або невиконання інших законних вимог посадових осіб Національного антикорупиійного бюро Украӥни.

Про можливість застосування такого способу збирання доказів, як витребування речей та документів, також зазначено у Інформаційному листі Вищого спеціалізованого суду України з розгляду цивільних і кримінальних справ про деякі питання здійснення слідчим суддею суду першої інстанції судового контролю за дотриманням прав, свобод та інтересів осіб під час застосування заходів забезпечення кримінального провадження від 05 квітня 2013 р. № 223-558/0/4-13.

Відповідно до п. 18 цього листа «Беручи до уваги зміст положень ч. 1 ст. 86, частин 2 та 3 ст.93 КПК України, застосування стороною кримінального провадження такого способу збирання доказів, як вилучення речей чи документів (ч. 7 ст. 163 КПК), під 
час отримання доступу до речей та документів може здійснюватись у випадках, якщо: 1) особа, у володінні якої знаходяться речі або документи, не бажає добровільно передати їх стороні кримінального провадження, або $є$ підстави вважати, що вона не здійснить таку передачу добровільно після отримання відповідного запиту чи намагатиметься змінити або знищити відповідні речі або документи; 2) речі та документи згідно зі ст. 162 КПК містять охоронювану законом таємницю, і таке вилучення необхідне для досягнення мети застосування цього заходу забезпечення. В інших випадках сторона кримінального провадження може витребувати та отримати речі або документи за умови їх добровільного надання володільием без застосування процедури, передбаченої главою 15 КПК» [3, с. 45].

Такіповноваження слідчого (детектива) знаходятьсвоєпідтвердження в ч. 4 ст. 132КПК України, в якій зазначено, що для оцінки потреб досудового розслідування слідчий суддя або суд зобов' язаний врахувати можливість без застосованого заходу забезпечення кримінального провадження отримати речі і документи, які можуть бути використані під час судового розгляду для встановлення обставин у кримінальному провадженні.

В Узагальненні судової практики щодо розгляду слідчим суддею клопотань про застосування заходів забезпечення кримінального провадження від 07.02.2014 підкреслено, що «при зверненні до суду з клопотаннями про тимчасовий доступ до речей і документів слідчими не виконуються вимоги ч. 2 ст. 93 КПК, згідно з якою сторона обвинувачення здійснює збирання доказів шляхом проведення слідчих (розшукових дій), витребування та отримання від органів державної влади, органів місцевого самоврядування, підприємств, установ, організацій, службових та фізичних осіб речей, документів, відомостей, висновків експертів, висновків ревізій та актів перевірок, проведення інших процесуальних дій, передбачених цим Кодексом» [4].

Окрім того, вказані повноваження детективів НАБУ врегульовані положеннями Закону України «Про Національне антикорупційне бюро України» [5]. Так, відповідно до п. 3 ч. 1 ст. 17 зазначеного Закону Національному бюро та його працівникам для виконання покладених на них обов' язків надається право витребовувати за рішенням керівника структурного підрозділу Національного бюро та одержувати в установленому законом порядку у вказаному в запиті вигляді та формі від інших правоохоронних та державних органів, органів місцевого самоврядування, підприємств, установ, організацій інформацію, необхідну для виконання обов'язків Національного бюро, у тому числі відомості про майно, доходи, видатки, фінансові зобов' язання осіб, які ними декларуються у встановленому законом порядку, відомості про використання коштів Державного бюджету України, розпорядження державним або комунальним майном.

В абзаці 2 п. 3 ч. 1 ст. 17 Закону встановлюється відповідальність за невиконання зазначених вимог детективів НАБ України: “Суб’єкти, яким адресовано зазначений запит, зобов' язані невідкладно, але не більше ніж протягом трьох робочих днів, надати відповідну інформацію. У разі неможливості надання інформації суб'єкт повинен так само невідкладно у письмовій формі повідомити про це Національне бюро з обгрунтуванням причин. Національне бюро за зверненням відповідного суб'єкта може продовжити строк надання інформації на строк не більше двох календарних днів. Ненадання Національному бюро на його запит інформації, надання завідомо недостовірної інформації чи не в повному обсязі, порушення встановлених законом строків їі надання, повідомлення третіх осіб стосовно того, що про них збирається така інформація, забороняються і тягнуть за собою відповідальність, передбачену законом».

Вищенаведений аналіз норм чинного законодавства підтверджує наявність повноважень детективів НАБ України щодо витребування речей, документів та інших відомостей як способу збирання доказів та їх законність. 
Для більш всебічного аналізу розглянемо окремі положення щодо використання під час здійснення досудового розслідування детективами НАБУ іншого інструменту отримання доказів - тимчасового доступу до речей і документів.

Відповідно до ст. 131 КПК України тимчасовий доступ до речей та документів $\epsilon$ одним із заходів забезпечення кримінального провадження.

Під заходами забезпечення кримінального провадження прийнято розуміти передбачені КПК заходи примусового характеру, які застосовуються за наявності підстав та в порядку, встановленому законом, з метою запобігання і подолання негативних обставин, що перешкоджають або можуть перешкоджати вирішенню завдань кримінального провадження, забезпеченню його дієвості [6, с. 367].

Підставами для застосування заходів забезпечення кримінального провадження КПК визначає: існування обгрунтованої підозри щодо вчинення кримінального правопорушення такого ступеня тяжкості, що може бути підставою для застосування заходів забезпечення кримінального провадження; потреби досудового розслідування виправдовують такий ступінь втручання у права і свободи особи, про який ідеться у клопотанні слідчого, прокурора; може бути виконане завдання, для виконання якого слідчий, прокурор звертається із клопотанням.

Відповідно до ч. 1 ст. 159 КПК України тимчасовий доступ до речей і документів полягає у наданні стороні кримінального провадження особою, у володінні якої знаходяться такі речі і документи, можливості ознайомитися з ними, зробити їх копії та вилучити їх (здійснити їх виїмку).

Тимчасовий доступ до електронних інформаційних систем або їх частин, мобільних терміналів систем зв'язку здійснюється шляхом зняття копії інформації, що міститься в таких електронних інформаційних системах або їх частинах, мобільних терміналах систем зв' язку, без їх вилучення.

У ч. 2 ст. 159 КПК України зазначено, що тимчасовий доступ до речей і документів здійснюється на підставі ухвали слідчого судді, суду, що своєю чергою є ознакою того, що тимчасовий доступ до речей та документів $є$ однією з форм судового контролю законності обмеження конституційних прав і свобод людини під час здійснення досудового розслідування, який покладається на слідчого суддю.

В загальному розумінні судовий контроль передбачає перевірку законності та обгрунтованості дій і рішень сторони обвинувачення, яка наділена державно-владними повноваженнями (прокурора, органу досудового розслідування, керівника органу досудового розслідування, оперативних підрозділів), а тому роль слідчого судді, здійснення ним судового контролю у сфері захисту особи, суспільства, держави від кримінальних правопорушень, охорони прав, свобод та законних інтересів учасників кримінального провадження набуває особливого значення.

Ст. 162 КПК містить у собі вичерпний перелік видів речей і документів, які становлять охоронювану законом таємницю. Слід акцентувати увагу слідчих суддів, що лише у разі подання клопотання про тимчасовий доступ до речей і документів, які містять охоронювану законом таємницю, зазначається про неможливість іншим способом довести обставини, які передбачається довести за допомогою цих речей і документів. За таких обставин вимога слідчих суддів до осіб, які звертаються із клопотанням про тимчасовий доступ до речей і документів, доводити, що іншими способами довести обставини, які передбачається довести за допомогою цих речей і документів, неможливо, є неправомірною.

В багатьох випадках формальністю та неналежною обгрунтованістю характеризуються клопотання про тимчасовий доступ до речей і документів, у яких порушується питання про їх вилучення. Органи досудового розслідування порушують питання 
про вилучення речей і документів під час зверненні до слідчих суддів з відповідними клопотаннями, належним чином не обгрунтовуючи необхідність вилучення речей, а в більшості випадків це стосується вилучення оригіналів документів без зазначення підстав, з яких для досягнення цілей кримінального провадження неможливо обмежитись вилученням належним чином засвідчених копій таких документів.

Зазначені колізії у практичній діяльності детективів НАБУ як представників сторони обвинувачення наштовхують нас на думку, що для упорядкування способів витребування речей та документів під час досудового розслідування доцільно передбачити необхідність звернення слідчим / детективом до слідчого судді із клопотанням про тимчасовий доступ до речей та документів у таких випадках:

1) коли існує необхідність у отриманні тимчасового доступу до оригіналів речей та документів;

2) коли існує необхідність у отриманні тимчасового доступу до речей та документів (копій або оригіналів), які містять у собі охоронювану законом таємницю.

Це забезпечить належне дотримання прав, свобод та інтересів осіб у кримінальному провадженні та встановить необхідний судовий контроль за вказаною процедурою.

У всіх інших випадках, витребування речей та документів може бути здійснено на підставі відповідної постанови (вимоги) слідчого / детектива або прокурора.

Зазначене повною мірою корелюється із чинними нормами кримінального процесуального законодавства, забезпечує здійснення судового контролю у кримінальному провадженні та виступає запорукою підвищення ефективності досудового розслідування та забезпечення здійснення його у розумні строки, оскільки це дасть можливість нівелювати надмірний бюрократизм у роботі слідчих / детективів та розвантажити слідчих суддів.

Висновки. Аналіз наукових джерел та процесуальної практики щодо витребування речей та документів під час здійснення досудового розслідування свідчить про неналежне законодавче врегулювання цього процесуального інструменту, дозволяє зробити певні висновки та сформулювати пропозиції щодо внесення змін та доповнень до КПК.

Так, до проблемних питань його правозастосування слід віднести:

- порядок та підстави звернення слідчого / детектива та прокурора з письмовою вимогою про витребування відомостей, документів і речей;

- законодавче врегулювання форми такої вимоги (наприклад, у формі постанови слідчого, детектива або прокурора);

- перелік визначених ознак змісту такої вимоги;

- порядок та строки ї̈ виконання;

- визначення відповідальності за невиконання вимог слідчого / детектива або прокурора, визначених у вимозі про витребування речей та документів.

Для удосконалення процедури застосування тимчасового доступу до речей і документів вважаємо за можливе запропонувати:

- частину 2 ст. 159 КПК викласти у наступній редакції: «Тимчасовий доступ до оригіналів речей і документів здійснюється на підставі ухвали слідчого судді, суду»;

- доповнити ст. 159 КПК України частиною 3 у наступній редакції: «Тимчасовий доступ до речей і документів, що містять охоронювану законом таємницю, здійснюється на підставі ухвали слідчого судді, суду. У інших випадках витребування речей та документів здійснюється на підставі відповідної постанови слідчого або прокурора». 


\section{Список використаних джерел:}

1. Шумило М.Є. Поняття доказів у кримінальному процесі: пролегомени до розуміння «невловного» феномену доказового права / М.Є. Шумило. Вісник кримінального судочинства. 2015. № 3. С. 95-104.

2. Кодекс України про адміністративні правопорушення. URL: https:/ / zakon.rada. gov.ua/laws/show/80731-10.

3. Інформаційний лист Вищого спеціалізованого суду України з розгляду цивільних і кримінальних справ про деякі питання здійснення слідчим суддею суду першої інстанції судового контролю за дотриманням прав, свобод та інтересів осіб під час застосування заходів забезпечення кримінального провадження від 05 квітня 2013 р. № 223-558/0/4-13. Часопис иивільного і кримінального судочинства. 2013. № 3. С. 33-46. URL: http://nbuv.gov.ua/UJRN/Chcks_2013_3_6.

4. Узагальнення судової практики щодо розгляду слідчим суддею клопотань про застосування заходів забезпечення кримінального провадження від 07.02.2014. URL: https:// zakon.rada.gov.ua/laws/show/n0001740-14.

5. Про Національне антикорупційне бюро: Закон України від 14 жовтня 2014 року № 1698-VII. URL: http:/ /zakon4.rada.gov.ua/laws/show/1698-18.

6. Кримінальний процесуальний кодекс Украӥни. Науково-практичний коментар: у 2 т. Т. 1 / О.М. Бандурка, Є.М. Блажівський, Є.П. Бурдоль та ін.; за заг.ред. В.Я. Тація, В.П. Пшонки, А.В. Портнова. Харків : Право, 2012.

7. БожкоО. Витребування відомостей, документів і речей стороною обвинувачення як самостійний спосіб збирання доказів у кримінальному провадженні / О. Божко, А. Ширяєв. Вісник Національної академії прокуратури України. 2018. № 2. С. 7-23.

8. Гловюк I.В. Тимчасовий доступ до речей і документів як захід забезпечення кримінального провадження, спрямований на збирання та перевірку доказів / І.В. Гловюк, С.В. Андрусенко. Порівняльно-аналітичне право. 2013. № 3-2. С. 293-296.

9. Ковальчук С.О. Способи збирання речових доказів стороною обвинувачення. Часопис Національного університету «Острозька академія». Сер. : Право. 2014. № 2.

10. Кримінальний процесуальний кодекс України: Закон України від 13 квітня 2012 року № 4651-VI. URL: http:/ / zakon4.rada.gov.ua/laws/show/4651-17.

11. Сліпченко B.I. Підстави та процесуальний порядок витребування речей i документів. Вісник Запорізького національного університету. Юридичні науки. 2014. № 4(2). C. 282-289. 


\section{ВИМОГИ ДО НАУКОВИХ СТАТЕЙ}

\section{1. ВИМОГИ ДО ЗМІСТУ НАУКОВОЇ СТАТТІ}

Наукова стаття повинна містити такі необхідні елементи:

- постановка проблеми у загальному вигляді та ї̈ зв'язок із важливими науковими чи практичними завданнями;

- аналіз останніх досліджень і публікацій з даної теми, в яких започатковано розв' язання даної проблеми і на які спирається автор, виділення невирішених раніше частин загальної проблеми, яким присвячується означена стаття;

- формулювання цілей статті (постановка завдання);

- виклад основного матеріалу дослідження 3 повним обгрунтуванням отриманих наукових результатів;

- висновки 3 даного дослідження і перспективи подальшої розвідки у даному напрямку.

\section{2. ВИМОГИ ДО ОФОРМЛЕННЯ ТЕКСТУ НАУКОВОЇ СТАТТІ}

2.1. Обсяг статті має бути від 8 до 20 сторінок, включаючи ілюстрації, таблиці, графіки, список використаних джерел.

- поля верхні та нижні, ліві і праві - 2,0 см.

- міжрядковий інтервал - 1,5

- шрифт «Times New Roman» - 14

- абзацний відступ - 0,5 см.

- текст вирівнюється по ширині.

2.2. Посилання на джерела необхідно робити по тексту у квадратних дужках із зазначенням номерів сторінок відповідно джерела. Наприклад: [3, с. 234] або [2, с. 35; 8, с. 234].

2.3. Список використаних джерел подається наприкінці статті в порядку згадування джерел та має бути оформлений відповідно до існуючих стандартів бібліографічного опису (див.: розроблений в 2015 році Національний стандарт України ДСТУ 8302:2015 «Інформація та документація. Бібліографічне посилання. Загальні положення та правила складання».

2.4. Стаття повинна містити назву, відомості про автора(ів) (прізвище, ім'я, по батькові, науковий ступінь, вчене звання, посада, місце роботи/навчання, місто, країна), анотації та ключові слова українською та англійською мовами; середній обсяг анотацій - не менш як 1800 друкованих знаків.

3 прикладом оформлення статті можна ознайомитись на сайті видання за посиланням: http:/ / www.lawbulletin.oduvs.od.ua/ priklad.

Редакція залишає за собою право на рецензування, редагування, скорочення і відхилення статей. За достовірність фактів, статистичних даних та іншої інформації відповідальність несе автор. Представлена автором стаття повинна являти собою продукт його власної ідеї. Не допускається плагіат у різних формах. Використання праць інших авторів можливо тільки як посилання, цитата, опис, але не переписування праці, запозичення ідей. При використанні інформації інших праць обов' язкове посилання на автора, його працю, видання, рік, сторінку. Передрук (перевидання) матеріалів видання дозволяється тільки з дозволу автора і редакції.

Редакція наукового журналу «Юридичний бюлетень»:

Україна, 73000, м. Херсон, вул. Потьомкінська 42/14

Контактний телефон: +38 (099) 7296859

Електронна адреса: editor@lawbulletin.oduvs.od.ua

Електронна сторінка: www.lawbulletin.oduvs.od.ua 
НОТАТКИ 
Наукове видання

\title{
Юридичний бюлетень
}

\author{
Науковий журнал
}

\section{Випуск 14}

Формат 60x84/8. Гарнітура Book Antiqua.

Папір офсет. Цифровий друк. Ум. друк. арк. 23,25.

Замов. № 1020/316. Наклад 300 прим.

Видавничий дім «Гельветика»

73021, м. Херсон, вул. Паровозна, 46-а

Телефон +38 (0552) 3995 80, +38 (095) 93448 28, +38 (097) 7230608

E-mail: mailbox@helvetica.com.ua

Свідоцтво суб'єкта видавничої справи

ДК № 6424 від 04.10.2018 p. 